Prepared in cooperation with the University of Oregon and the U.S. Fish and Wildlife Service

\title{
Geomorphology and Flood-Plain Vegetation of the Sprague and Lower Sycan Rivers, Klamath Basin, Oregon
}

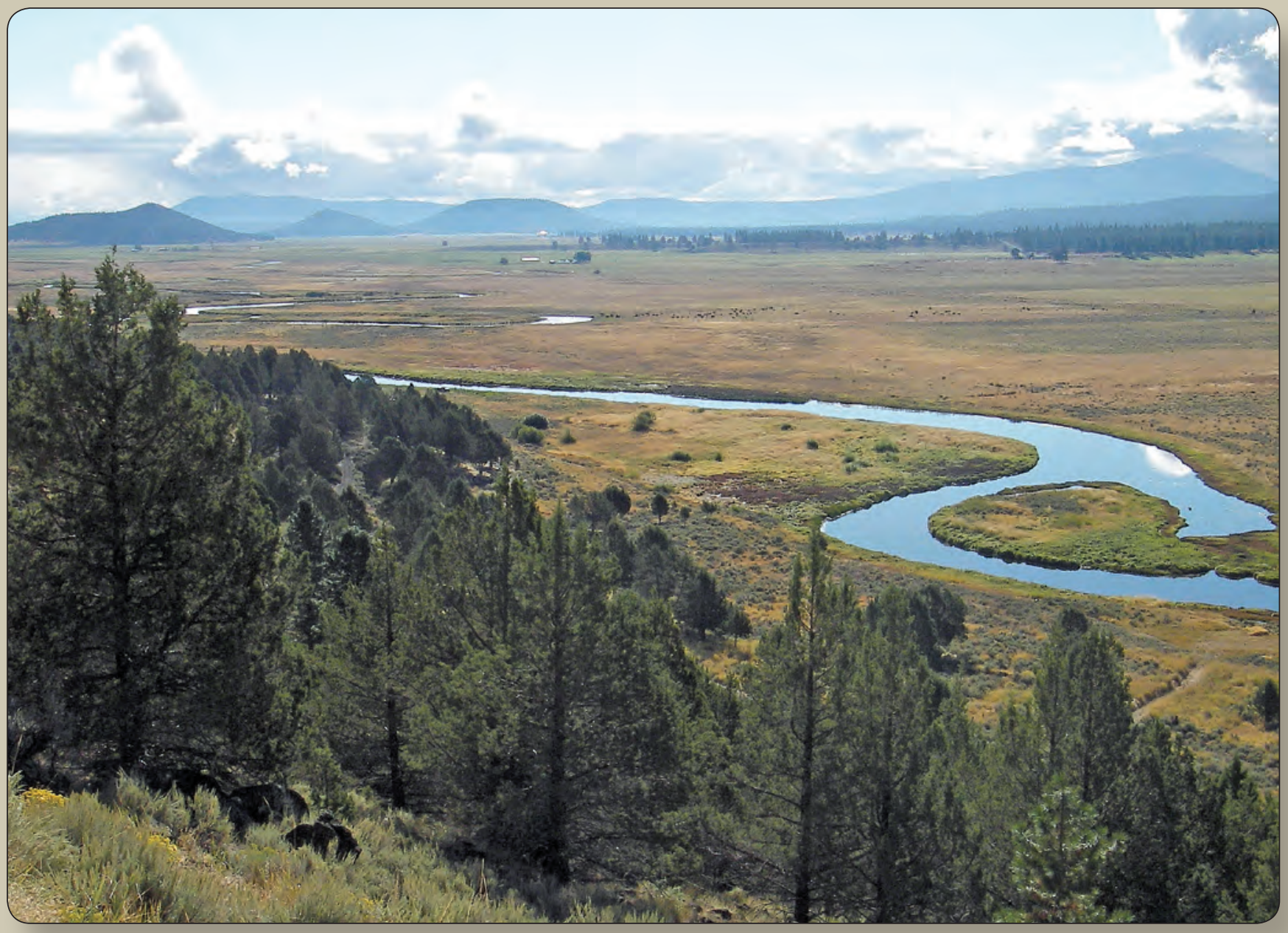

Scientific Investigations Report 2014-5223 
Cover: Council Butte valley segment looking upstream from near flood-plain kilometer 59.2, Sprague River Basin, Oregon. Photograph taken by J.E. O'Connor, U.S. Geological Survey, September 16, 2006. 


\section{Geomorphology and Flood-Plain Vegetation of the Sprague and Lower Sycan Rivers, Klamath Basin, Oregon}

By Jim E. O'Connor, Patricia F. McDowell, Pollyanna Lind, Christine G. Rasmussen, and Mackenzie K. Keith

Prepared in cooperation with the University of Oregon and the U.S. Fish and Wildlife Service

Scientific Investigations Report 2014-5223 


\title{
U.S. Department of the Interior SALLY JEWELL, Secretary
}

\section{U.S. Geological Survey Suzette M. Kimball, Acting Director}

\author{
U.S. Geological Survey, Reston, Virginia: 2015
}

For more information on the USGS - the Federal source for science about the Earth, its natural and living resources, natural hazards, and the environment, visit http://www.usgs.gov or call 1-888-ASK-USGS.

For an overview of USGS information products, including maps, imagery, and publications, visit http://www.usgs.gov/pubprod

To order this and other USGS information products, visit http://store.usgs.gov

Any use of trade, firm, or product names is for descriptive purposes only and does not imply endorsement by the U.S. Government.

Although this information product, for the most part, is in the public domain, it also may contain copyrighted materials as noted in the text. Permission to reproduce copyrighted items must be secured from the copyright owner.

Suggested citation:

O'Connor, J.E., McDowell, P.F., Lind, Pollyanna, Rasmussen, C.G., and Keith, M.K., 2015, Geomorphology and floodplain vegetation of the Sprague and lower Sycan Rivers, Klamath Basin, Oregon: U.S. Geological Survey Scientific Investigations Report 2014-5223, 122 p., 1 pl., http://dx.doi.org/10.3133/sir20145223.

ISSN 2328-0328 (online) 


\section{Contents}

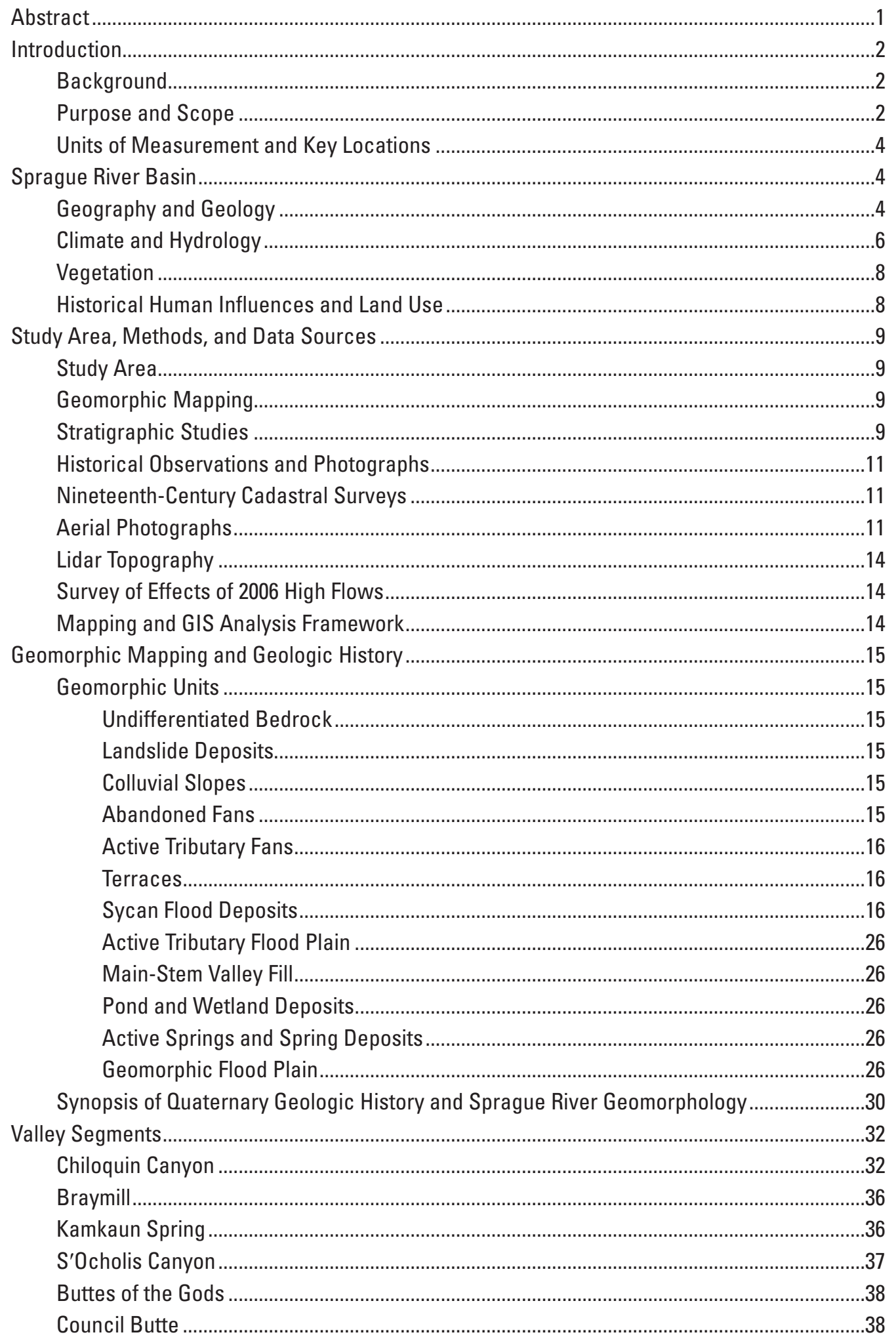




\section{Contents-Continued}

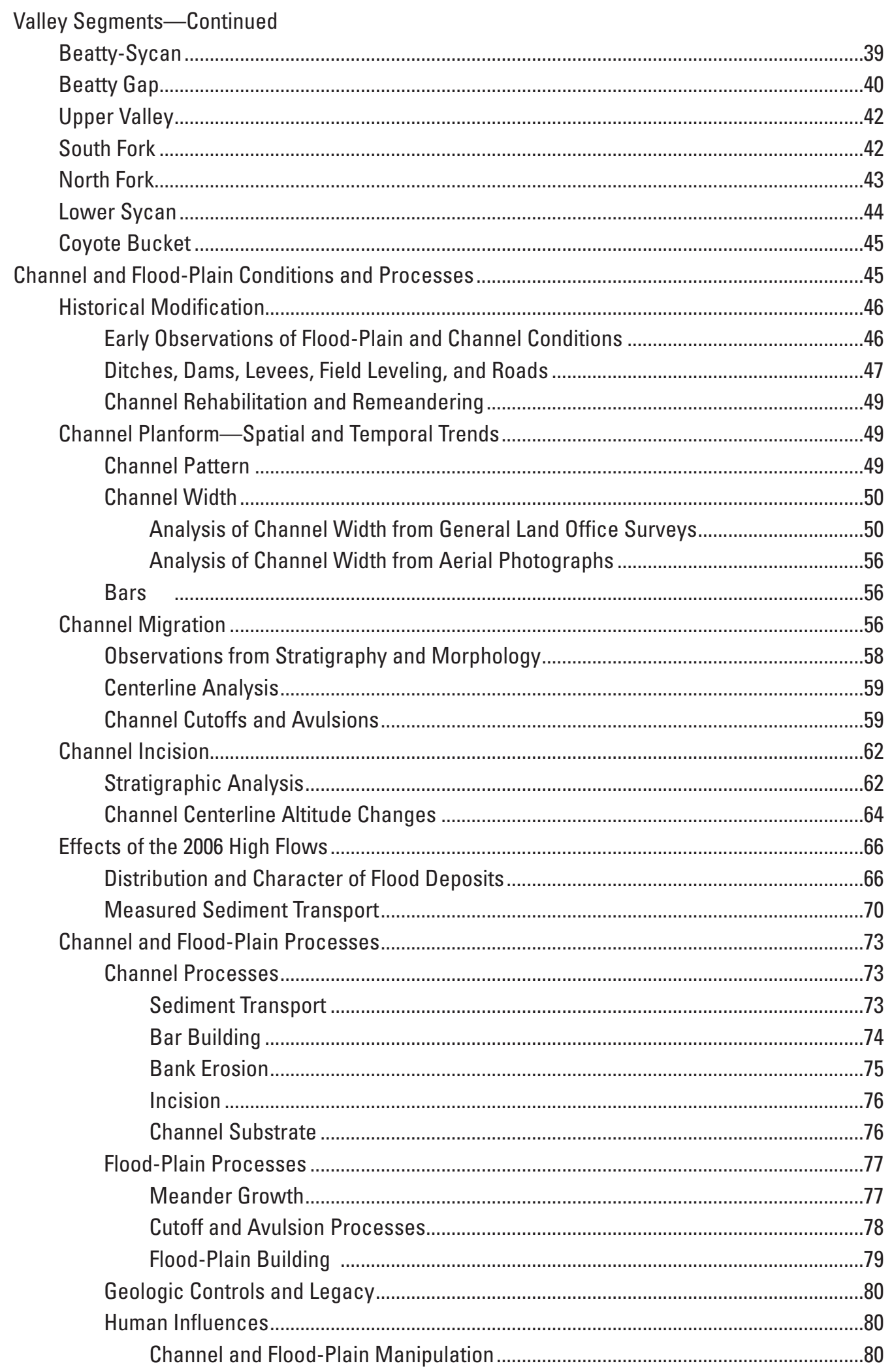




\section{Contents-Continued}

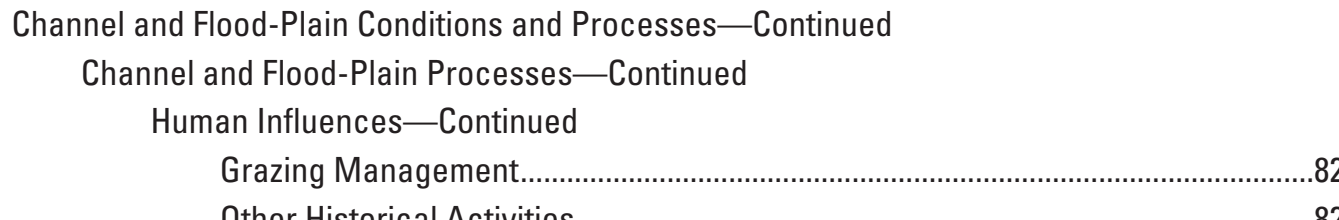

Summary of Physical Flood-Plain and Channel Conditions, Processes, and Trends ..............83

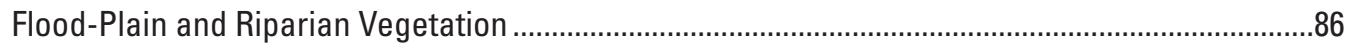

Overview of Current Flood-Plain Vegetation ......................................................................86

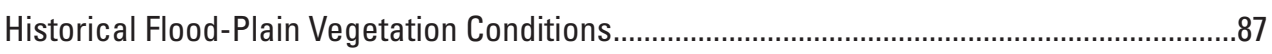

Vegetation Conditions Inferred from GLO Surveys and Notes.......................................87

Historical Notes from Botanist William E. Lawrence ..................................................87

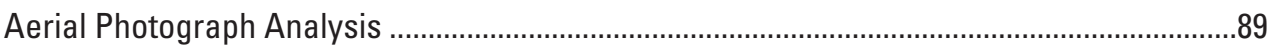

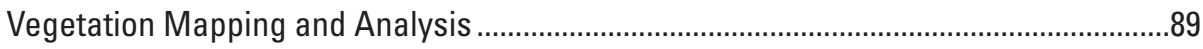

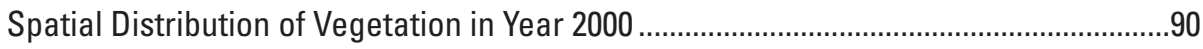

Vegetation Trends, 1940-2000 .............................................................................90

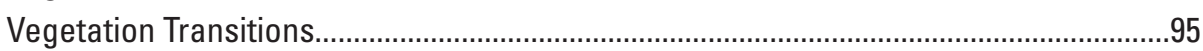

Major Vegetation Changes and Their Causes ........................................................................99

Transitions Among Water, Bare, and Herbaceous Cover Classes ...................................99

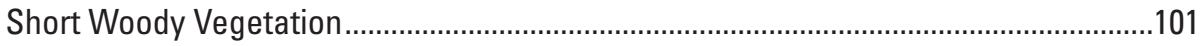

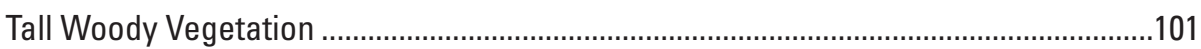

Summary of Flood-Plain and Near-Channel Vegetation Conditions.....................................102

Implications for Restoration and Monitoring .........................................................................102

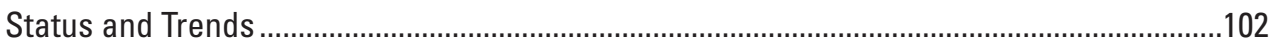

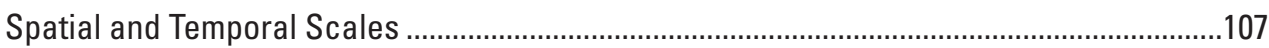

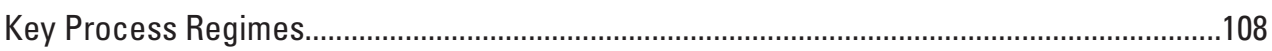

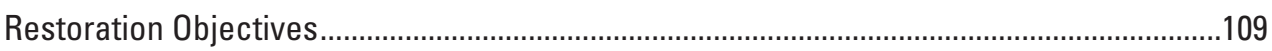

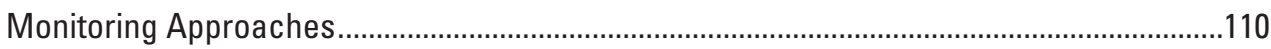

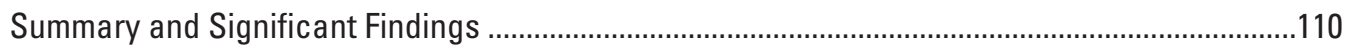

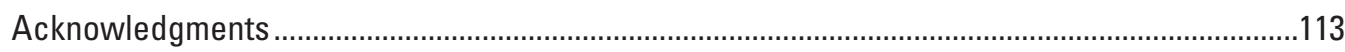

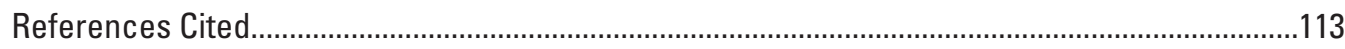

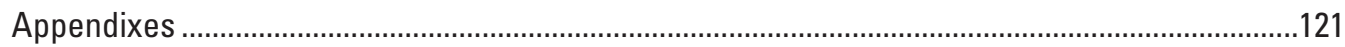

Appendix A. Locations of Stratigraphic Analysis, Sprague River Study Area, Oregon .......121

Appendix B. Radiocarbon Analyses, Sprague River Study Area, Oregon ...........................121

Appendix C. Volcanic Glass Compositions of Tephra, Sprague River Study Area,

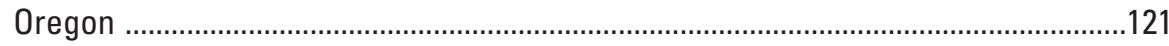

Appendix D. Cesium-137 Content, Sprague River Study Area, Oregon .................................121

Appendix E. Geomorphic Map Units, Sprague River Study Area, Oregon............................121

Appendix F. Comparison of General Land Office Section-Line Measurements of River Width with Width from 2000 Aerial Photographs, Sprague River Study Area, Oregon.

Appendix G. Survey Sites of Effects of 2006 High Flows, Sprague River Study Area, Oregon

Appendix H. Vegetation Transitions in the Geomorphic Flood Plain and Near-Channel

Areas for 1940-1968 and 1968-2000, Sprague River Study Area, Oregon .................121 


\section{Plate}

1. Geomorphic surfaces of the Sprague and Lower Sycan Rivers, Oregon.

\section{Figures}

1. Map showing valley segments in the study area, selected locations, and streamflow-gaging stations, Sprague River Basin, south-central Oregon

2. Graphs showing annual peak discharge for streamflow-gaging stations at Sprague River near Chiloquin, station 11501000; Sycan River below Snake Creek near Beatty, station 11499100; and Sprague River near Beatty, station 11497500, Sprague River Basin, Oregon 7

3. Graph showing mean daily discharge for selected streamflow-gaging stations, Sprague River Basin, Oregon

4. Stratigraphic sections showing Late Quaternary exposures at flood-plain kilometer (FK) 55.0, FK 79.4, FK 87.6, and Sycan flood-plain kilometer 2.5, Sprague River study area, Oregon.

5. Stratigraphic sections of Sycan River flood-plain kilometers (SYFK) 0.02 and 0.1; SYFK 1.6 and 1.7; SYFK 3.5; SYFK 6.8 and 7.3; and SYFK 10.1, 10.3, and 10.6, Sprague River study area, Oregon....

6. Graph showing flood-plain and terrace surface profiles estimated from stratigraphic sections and observations along lower Sycan River, Sprague River study area, Oregon

7. Photographs showing pumiceous sand deposits of the Sycan flood about 7,700 calendar years before present at exposed site 7/2/05-1, Sycan River flood-plain kilometer (SYFK) 10.1 (July 2, 2005); and site 9/12/06-2, SYFK 6.1 (June 20, 2006), lower Sycan River valley segment, Sprague River study area, Oregon

8. Stratigraphic sections of flood-plain kilometer (FK) 26.3, FK 82.4, FK 87.7, and FK 98.5, along main-stem and South Fork Sprague River geomorphic flood plain, Oregon .........24

9. Stratigraphic sections of North Fork Sprague River flood-plain kilometer (NFFK) 0.7, and NFFK 1.2, along North Fork Sprague River geomorphic flood plain, Oregon.

10. Photograph showing Mazama fallout tephra and Sycan flood deposits exposed at site 7/24/07-2/3, Sycan River flood-plain kilometer (SYFK) 0.02, Sprague River study area, Oregon.

11. Stratigraphic diagram and photograph showing late Holocene inset flood-plain deposits at the right-bank exposure at North Fork Sprague River flood-plain kilometer (NFFK) 0.7, and left-bank exposure at NFFK 0.9, along North Fork Sprague River, Oregon .....

12. Cross sections and map showing former paleochannel locations and augering transects between flood-plain kilometers (FK) 48.2 and 49.0, Buttes of the Gods valley segment, Sprague River study area, Oregon.

13. Map and graph showing former paleochannel locations and augering transects between flood-plain kilometers (FK) 30.6 and 32.0, Kamkaun Spring valley segment, Sprague River study area, Oregon.

14. Diagram showing stratigraphic relation among flood-plain and terrace deposits in Lower Sycan valley segment, Sycan River flood-plain kilometer 3.5, Sprague River study area, Oregon

15. Photographs showing point bar deposits at survey site $6 / 23 / 06-5$ with view downstream of partly vegetated point bar mantled with coarse sand deposited during 2006 high flows, and 30-centimeter-deep excavation into 2006 high flow deposits showing bedded coarse sand composed mainly of pumice grains, Upper Valley segment, Sprague River study area, Oregon 


\section{Figures-Continued}

16. Graph showing geomorphic units within 10 meters of primary channel edge for channel location during 2000, Sprague River Basin, Oregon..

17. Graphs showing spatial trends in flood-plain altitude, flood-plain width, and channel sinuosity, Sprague River Basin, Oregon.

18. Graphs showing spatial trends in channel water-surface altitude, channel width, and bar width, Sprague River Basin, Oregon.

19. Photographs showing Chiloquin Canyon valley segment with view downstream of bridge crossing at flood-plain kilometer (FK) 8.8, and view upstream across pool behind the decommissioned Chiloquin Dam at FK 1.3, Sprague River Basin, Oregon....35

20. Historical photographs associated with discontinued U.S. Geological Survey (USGS) streamflow-gaging station 11502000 at flood-plain kilometer (FK) 0.7, with view upstream from former wagon bridge crossing of the Sprague River at FK 0.7 (May 2 (?), 1918; view downstream from near USGS gaging station (May 6, 1918); bridge visible in upper right of image); and view of USGS gage house on right bank of Sprague River near Chiloquin, Oregon.

21. Photograph showing Braymill valley segment looking southwest from near flood-plain kilometer 14.5, Sprague River Basin, Oregon

22. Photograph showing Kamkaun Spring valley segment at flood-plain kilometer 26.8, Sprague River Basin, Oregon . . .36

23. Photograph showing filled cutoff channel at flood-plain kilometer 25.3, Kamkaun Spring valley segment, Sprague River Basin, Oregon.

24. Photograph showing $S^{\prime}$ Ocholis Canyon valley segment at flood-plain kilometer 34.1, Sprague River Basin, Oregon ...

25. Photograph showing Buttes of the Gods valley segment looking upstream from flood-plain kilometer 49.2, Sprague River Basin, Oregon

26. Photograph showing Council Butte valley segment looking upstream from near flood-plain kilometer 59.2, Sprague River Basin, Oregon

27. Photograph showing Beatty-Sycan valley segment looking northwest (upstream) from flood-plain kilometer 78.5, Sprague River Basin, Oregon.

28. Photograph showing Beatty Gap valley segment looking west (downstream) from flood-plain kilometer 85.2, Sprague River Basin, Oregon

29. Photographs showing approximately matched locations at flood-plain kilometer 81.4 near the downstream end of the Beatty Gap valley segment, Sprague River Basin, Oregon....

30. Photograph showing Upper Valley segment looking downstream from flood-plain kilometer 88.5, Sprague River Basin, Oregon.

31. Photographs showing South Fork valley segment looking downstream from Ivory Pine Road bridge crossing at flood-plain kilometer (FK) 94.3 (March 9, 2004); and upstream from diversion at FK 98.6 (June 20, 2007), Sprague River Basin, Oregon ........42

32. Graph showing approximate water-surface profiles from 1-meter spacing lidar data along 2004 channel centerlines, North Fork and South Fork Sprague Rivers, Oregon...43

33. Photograph showing Lower Sycan valley segment looking downstream from Sycan River flood-plain kilometer 10.7, Sprague River Basin, Oregon

34. Photograph showing Sycan River flowing on Tertiary lacustrine sediment at Sycan River flood-plain kilometer 1.2 in the Lower Sycan valley segment, Sprague River Basin, Oregon

35. Photograph showing Coyote Bucket valley segment of the Sycan River looking downstream from near Sycan River flood-plain kilometer 13.2, Sprague River Basin, Oregon. 


\section{Figures-Continued}

36. Graphs showing extent of cultural features in the flood plain, including irrigation and drainage ditches; levees and dikes; roads; and total area covered by ditches, levees, roads, dams, diversions, and structures, as mapped from 1940, 1968, and 2000 aerial photographs, summed by valley segment, Sprague River Basin, Oregon....48

37. Map showing flood-plain topography smoothed by field leveling between flood-plain kilometers 91.0 and 93.0, Upper Valley segment, just downstream of confluence of South Fork and North Fork Sprague Rivers, Sprague River Basin, Oregon

38. Graphs showing summary plan-view channel and flood-plain characteristics, including channel slope, channel sinuosity, primary channel area, secondary channel area, backwater area, and bar area, as mapped from 1940, 1968, and 2000

aerial photographs, summed by valley segment, Sprague River Basin, Oregon

39. Graphs showing spatial trends in channel and bar features, as mapped from aerial photographs taken in 2000, Sprague River Basin, Oregon

40. Vertical aerial photographs showing examples of meander cutoffs, avulsions, and anabranches, including neck cutoff and avulsion between flood-plain kilometers (FKs) 25.0 and 26.0, Kamkaun Spring valley segment; meander cutoffs formed along levees between FKs 64.0 and 65.0; and anabranches spanning many meander loops between FKs 74.0 and 77.0, Sprague River Basin, Oregon

41. Graphs showing General Land Office (GLO) surveyed (chiefly in 1866) widths compared with measured widths from aerial photographs taken in 2000 for 62 GLO surveyed widths and at the same location as determined from aerial photographs; and relation between GLO and widths in 2000 by valley segment, Sprague River Basin, Oregon

42. Graphs showing spatial trends in channel width, as mapped from aerial photographs taken in 1940, 1968, and 2000, Sprague River Basin, Oregon

43. Boxplot showing wetted channel width measurements summarized by valley segment, Sprague River Basin, Oregon.

44. Graphs showing spatial trends in lateral channel migration rate determined from channel centerline positions, as mapped from General Land Office (GLO) maps and aerial photographs from 1940, 1968, 1975, 2000, and 2005, Sprague River Basin, Oregon

45. Boxplot showing channel migration rate measurements summarized by valley segment, Sprague River Basin, Oregon.

46. Graphs showing migration rate correlations and confidence intervals along valley segment summarized variables, Sprague River Basin, Oregon.

47. Map showing locations and timing of avulsions and cutoffs evident from map and aerial photograph analysis, Sprague River Basin, Oregon

48. Diagram showing flood-plain transect, illustrating the approach for assessing vertical channel movement from intercepts between channel centerline positions and 2005 lidar topography, Sprague River study area, Oregon.

49. Graphs showing spatial trends in channel-centerline altitude differences, as mapped from 2004 (lidar) in conjunction with sequential channel centerline positions, as mapped from General Land Office (GLO) maps and aerial photographs taken in 1940, 1968, 1975, 2000, and 2005, Sprague River study area, Oregon.

50. Graph showing mean daily discharge during water year 2006 for select streamflow-gaging stations, Sprague River Basin, Oregon 


\section{Figures-Continued}

51. Map showing sites assessed in the summer of 2006 for water year 2006 sediment

deposition and flood altitude, Sprague River Basin, Oregon

52. Graphs showing summary observations of 2006 survey of deposits and inundation levels of water year 2006 floods, including longitudinal trends of deposits and inundation evidence; and summary plots of 2006 flood deposit texture and altitude, grouped by bar and flood-plain settings, main-stem Sprague River, Oregon ......

53. Photographs showing examples of sediment deposition resulting from the 2006 high flows, including overbank deposition of 4.5 centimeters of silt and sand on low flood-plain surface, Council Butte valley segment; and deposition of 33 centimeters of sand on point bar, Beatty Gap valley segment, main-stem Sprague River, Oregon ...69

54. Photograph showing Kamkaun Spring valley segment, looking north, main-stem Sprague River, Oregon, during high flow in water year 2006.

55. Graphs showing discharge and suspended sediment transport between December 20, 2005 and January 7, 2006 period of high flows for seven locations in the Sprague River Basin, Oregon

56. Graphs showing longitudinal trends in discharge and suspended sediment transport for 6 days of observations and at near-peak discharge

57. Photographs showing examples of bank erosion with down-dropped blocks of flood-plain deposits, including left-bank erosion in S'Ocholis Canyon valley segment, and right-bank erosion in Kamkaun Spring valley segment, main-stem Sprague River, Oregon

58. Map showing channels, possibly caused by ice jams, formed on Sprague River flood plain, Oregon

59. Graph showing avulsions and cutoffs, summarized by valley segment, Sprague River Basin, Oregon.

60. Graphs showing summary trends of major flood-plain and channel attributes, summarized by valley segment, Sprague River Basin, Oregon

61. Graphs showing extent of mapped cover types in the geomorphic flood plain, summarized by valley segment, Sprague Valley Basin, Oregon.

62. Graphs showing extent of mapped cover types in the near-channel area, summarized by valley segment, Sprague Valley Basin, Oregon.

63. Graphs showing percentage of valley segment area in which cover type changed in entire geomorphic flood plain, and near-channel area, Sprague River Basin, Oregon, during 1940-1968 and 1968-2000 analysis periods.

64. Graphs showing cover-type transitions for geomorphic flood plain, summarized by valley segment, during 1940-1968, and 1968-2000, Sprague River Basin, Oregon.

65. Graphs showing cover-type transitions for the 40-meter-wide, near-channel zone centered about 1940 channel centerline, summarized by valley segment, during 1940-1968, and 1968-2000, Sprague River Basin, Oregon ...

66. Graphs showing summary of seral stage trends in entire geomorphic flood plain, and near-channel area, Sprague River Basin, Oregon, during 1940-1968 and 1968-2000

67. Photograph showing trampled sand-and-gravel point bar looking upstream near Sycan River flood-plain kilometer 0.1 along Sycan River, Oregon 


\section{Tables}

1. Locations of notable features in the Sprague River study area, Oregon ..........................5

2. General valley segment characteristics, Sprague River Basin, Oregon...........................10

3. Early (1865-92) General Land Office surveys in the Sprague River study area, Oregon

4. Primary data sources for maps and aerial photographs of the Sprague River study area, Oregon.

5. Features mapped from the 1940,1968 , and 2000 aerial photography in the geomorphic flood plain, Sprague River study area, Oregon

6. Mapped built features in the Sprague River geomorphic flood plain, Oregon

7. Channel width measurements from General Land Office section-line and meander surveys, Sprague River Basin, Oregon

8. Avulsion and cutoff frequency, Sprague River Basin, Oregon.

9. Vegetation notes from General Land Office surveys, by valley segment, Sprague

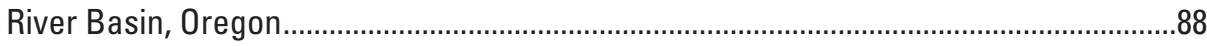

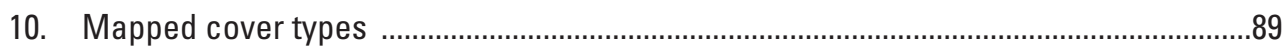

11. Cover types in valley segments of the geomorphic flood plain, Sprague Valley Basin, Oregon

12. Cover types in valley segments of the near-channel area, Sprague Valley Basin, Oregon

13. General valley segment trends and conditions, with implications for restoration, Sprague River Basin, Oregon 


\section{Conversion Factors and Datums}

\section{Conversion Factors}

\begin{tabular}{|c|c|c|}
\hline Multiply & By & To obtain \\
\hline \multicolumn{3}{|c|}{ Length } \\
\hline mile (mi) & 1.609 & kilometer (km) \\
\hline \multicolumn{3}{|c|}{ Area } \\
\hline acre & 0.004047 & square kilometer $\left(\mathrm{km}^{2}\right)$ \\
\hline square mile $\left(\mathrm{mi}^{2}\right)$ & 259.0 & hectare (ha) \\
\hline square mile $\left(\mathrm{mi}^{2}\right)$ & 2.590 & square kilometer $\left(\mathrm{km}^{2}\right)$ \\
\hline \multicolumn{3}{|l|}{ SI to Inch/Pound } \\
\hline Multiply & By & To obtain \\
\hline \multicolumn{3}{|c|}{ Length } \\
\hline centimeter $(\mathrm{cm})$ & 0.3937 & inch (in.) \\
\hline meter $(\mathrm{m})$ & 3.281 & foot $(\mathrm{ft})$ \\
\hline meter $(\mathrm{m})$ & 1.094 & yard (yd) \\
\hline kilometer (km) & 0.6214 & mile (mi) \\
\hline \multicolumn{3}{|c|}{ Area } \\
\hline hectare (ha) & 2.471 & acre \\
\hline hectare (ha) & 0.003861 & square mile $\left(\mathrm{mi}^{2}\right)$ \\
\hline square kilometer $\left(\mathrm{km}^{2}\right)$ & 247.1 & acre \\
\hline square meter $\left(\mathrm{m}^{2}\right)$ & 10.76 & square foot $\left(\mathrm{ft}^{2}\right)$ \\
\hline square kilometer $\left(\mathrm{km}^{2}\right)$ & 0.3861 & square mile $\left(\mathrm{mi}^{2}\right)$ \\
\hline \multicolumn{3}{|c|}{ Volume } \\
\hline cubic kilometer $\left(\mathrm{km}^{3}\right)$ & 0.2399 & cubic mile $\left(\mathrm{mi}^{3}\right)$ \\
\hline cubic meter $\left(\mathrm{m}^{3}\right)$ & 35.31 & cubic foot $\left(\mathrm{ft}^{3}\right)$ \\
\hline cubic meter $\left(\mathrm{m}^{3}\right)$ & 0.0008107 & acre-foot (acre-ft) \\
\hline \multicolumn{3}{|c|}{ Flow rate } \\
\hline cubic meter per second $\left(\mathrm{m}^{3} / \mathrm{s}\right)$ & 35.31 & cubic foot per second $\left(\mathrm{ft}^{3} / \mathrm{s}\right)$ \\
\hline \multicolumn{3}{|c|}{ Mass } \\
\hline $\operatorname{gram}(\mathrm{g})$ & 0.03527 & ounce, avoirdupois (oz) \\
\hline kilogram (kg) & 2.205 & pound avoirdupois (lb) \\
\hline \multicolumn{3}{|c|}{ Radioactivity } \\
\hline becquerel per liter $(\mathrm{Bq} / \mathrm{L})$ & 27.027 & picocurie per liter $(\mathrm{pCi} / \mathrm{L})$ \\
\hline
\end{tabular}

\section{Datums}

Vertical coordinate information is referenced to the North American Vertical Datum of 1988 (NAVD 88).

Horizontal coordinate information is referenced to the North American Datum of 1983 (NAD 83).

Altitude, as used in this report, refers to distance above the vertical datum. 



\title{
Geomorphology and Flood-Plain Vegetation of the Sprague and Lower Sycan Rivers, Klamath Basin, Oregon
}

\author{
By Jim E. O'Connor ${ }^{1}$, Patricia F. McDowell², Pollyanna Lind ${ }^{2}$, Christine G. Rasmussen², and Mackenzie K. Keith ${ }^{1}$
}

\section{Abstract}

This study provides information on channel and flood-plain processes and historical trends to guide effective restoration and monitoring strategies for the Sprague River Basin, a primary tributary (via the lower Williamson River) of Upper Klamath Lake, Oregon. The study area covered the lower, alluvial segments of the Sprague River system, including the lower parts of the Sycan River, North Fork Sprague River, South Fork Sprague River, and the entire main-stem Sprague River between the confluence of the North Fork Sprague and the South Fork Sprague Rivers and its confluence with the Williamson River at Chiloquin, Oregon. The study included mapping and stratigraphic analysis of flood-plain deposits and flanking features; evaluation of historical records, maps and photographs; mapping and analysis of flood-plain and channel characteristics (including morphologic and vegetation conditions); and a 2006 survey of depositional features left by high flows during the winter and spring of 2005-06.

Analyses focused on the channel and flood plain within an area defined as the "geomorphic flood plain," an area encompassing active fluvial and riparian processes. The geomorphic flood plain was subdivided into 13 valley segments of distinct fluvial environments on the basis of valley form and major tributary junctions: nine segments span the 136.1 kilometers of main-stem Sprague River, two segments for the lower Sycan River, and one segment for each part of the South Fork Sprague and North Fork Sprague Rivers within the study area. Segment characteristics range from steep and narrow canyons to low-gradient reaches with expansive flood plains. The wide flood-plain valley segments are broadly similar; most contain a sinuous, low-gradient channel that migrates slowly across the valley bottom. The narrow valley segments include the steep, boulder-andcobble-bed reaches at downstream and upstream ends of the study area as well as other confined valley segments that have

\footnotetext{
${ }^{1}$ U.S. Geological Survey.

${ }^{2}$ Department of Geography, University of Oregon
}

similar gradients and substrates as adjacent unconfined valley segments, but much lower sinuosities. Although the geologic setting of the expansive South Fork valley segment resulted in historical conditions of sinuous and poorly defined channels and wet meadows, flanking levees now narrowly confine the channelized South Fork Sprague River for much of its length.

Stratigraphic analyses show that before the Mazama eruption of 7,700 calendar years before present, wetlands and low flood plains flanked the main rivers of the study area. The eruption, however, covered much of the northern basin with sand- and granule-size pumice clasts, transforming channels by increasing bed-material transport and promoting bar formation and channel migration, particularly for the Sycan and North Fork Sprague Rivers, and for the Sprague River downstream of the Sycan River confluence. The South Fork Sprague River, which had much less Mazama pumice deposited in its watershed, remained a wet-meadow fluvial system until historical channelization and diking.

The analysis of historical maps and aerial photographs covering the geomorphic flood plain show changes in sinuosity, migration rates, and vegetation conditions since the 1800s. Most quantitative information is for the period between 1940 and 2000. The decrease in sinuosity since 1940 for nearly all the unconfined reaches resulted partly from decreased migration rates, but mostly from several cutoffs and avulsions formed between 1940 and 1975. The river shortening and steepening possibly resulted from (1) flood-plain confinement by levees, dikes, roads, and railroads leading to deeper and faster overbank flow, thereby promoting erosion of new flood-plain channels; and (2) flood-plain disturbances such as trails, ditches, and vegetation manipulation or eradication that locally concentrated overbank flow and decreased surface resistance to channel erosion.

The most evident vegetation change has been the loss of short woody vegetation adjacent to the river channels: only one-half the near-channel area covered by short woody vegetation in 1940 was similarly covered in 2000 . Woody vegetation removal in the 1950s and 1960s and continuing grazing and trampling by livestock probably are the main reasons for the decrease in short woody vegetation from the dense riparian corridors of willows (Salix sp.) and other riparian shrubs noted in the early 20 th century. 
The alluvial corridor of the South Fork Sprague River, compared to other Sprague River Basin rivers, has been the most substantially transformed since first historical observations. The present channel is incised, straightened, and separated from the rarely inundated flood plain by levees.

Despite these effects of human disturbances, many of the fundamental physical processes forming the Sprague River fluvial systems over the last several thousand years still function. In particular, flows are unregulated, sediment transport processes are active, and overbank flooding allows for floodplain deposition and erosion. Therefore, restoration of many of the native physical conditions and processes is possible without substantial physical manipulation of current conditions for much of the Sprague River study area. An exception is the South Fork Sprague River, where historical trends are not likely to reverse until it attains a more natural channel and flood-plain geometry and the channel aggrades to the extent that overbank flow becomes common.

\section{Introduction}

The Sprague River Basin encompasses 4,167 square kilometers $\left(\mathrm{km}^{2}\right)$ of south-central Oregon and is a principle tributary (via the Williamson River) of Upper Klamath Lake (fig. 1). The main-stem Sprague River, as well as the lower reaches of the North Fork Sprague River, the South Fork Sprague River, and the Sycan River meander through broad alluvial valleys and have historically supported agriculture and livestock grazing. National and regional interest in restoring Klamath Basin ecosystem conditions and processes has motivated several restoration strategies and projects in the Sprague River Basin to improve aquatic, riparian, and upland habitat conditions, particularly for endangered fish species (National Research Council, 2004). The goal of this study was to help management and regulatory agencies evaluate restoration proposals and to guide effective restoration and monitoring strategies for the Sprague River and its primary tributaries by summarizing the overall geomorphic setting and historical and current channel and flood-plain processes and conditions. The study was jointly conducted by the U.S. Geological Survey (USGS) and University of Oregon, in cooperation with the U.S. Fish and Wildlife Service Klamath Basin Ecosystem Restoration Office and the Hatfield Restoration Program.

\section{Background}

The Sprague and Sycan Rivers are like many rivers in the western United States for which issues of fish habitat, water quality, climate change, and land use changes have motivated new efforts to manage rivers and flood plains for many purposes. These efforts commonly aim to restore river systems where aquatic and riparian habitats have been degraded by historical land use activities, which in the Sprague River Basin include timber harvest, agriculture, and livestock grazing. A key issue for the Sprague River Basin is that it provides spawning and rearing habitat for two fish species listed under the Endangered Species Act: the Lost River (Deltistes luxatus) and shortnose (Chasmistes brevirostris) suckers. Additionally, the importance of the Sprague River and its tributaries in maintaining and protecting valued fish species is heightened by the removal in 2008 of Chiloquin Dam on the Sprague River $1.3 \mathrm{~km}$ upstream of its confluence with the Williamson River, and the possibility of changing or removing lower Klamath River dams, thus allowing reintroduction of anadromous salmonid species that once ranged into the basin (Hamilton and others, 2005).

Water withdrawals, increased stream temperature, high nutrient levels, riparian livestock grazing, and channelization likely have affected aquatic habitat in the Sprague River (Boyd and others, 2002; National Research Council, 2004). These factors have motivated several restoration activities in the Sprague River Basin, including many channel and flood-plain engineering projects, riparian management programs, and upland and flood-plain vegetation treatment programs (U.S. Department of Agriculture, 2009; NewFields River Basin Services and Kondolf, G. M., 2012). Such projects, however, are most likely to be successful if designed, implemented, and monitored with an understanding of the geomorphic context and recent history of the local landscape (Thorne and others, 1997; Kondolf and Piegay, 2003).

\section{Purpose and Scope}

The objective of this study of the Sprague River Basin was to provide an understanding of recent changes to the fluvial systems of the basin, including important physical processes, river and flood-plain geomorphic conditions, and flood-plain and near-channel vegetation. The primary focus of this analysis was the 136.1 kilometers $(\mathrm{km})$ of the main-stem Sprague River, the lower $15.6 \mathrm{~km}$ of the North Fork Sprague River, the lower $14.8 \mathrm{~km}$ of the South Fork Sprague River, and the lower $30.1 \mathrm{~km}$ of the Sycan River. Collectively, this part of the river network encompasses most of the low-gradient reaches historically subject to agriculture and livestock grazing, as well as more recent channel restoration activities. Analyses and findings were supported by (1) mapping and measurement of channel and flood-plain features, including vegetation, from historical maps and aerial photographs, and from high resolution Light Detection and Ranging (lidar) topographic data acquired in 2004; (2) stratigraphic measurements and analyses of flood-plain deposits; (3) surveys of the effects of 2006 high flows, and (4) geomorphic mapping based on soils, sedimentology, and topography. 


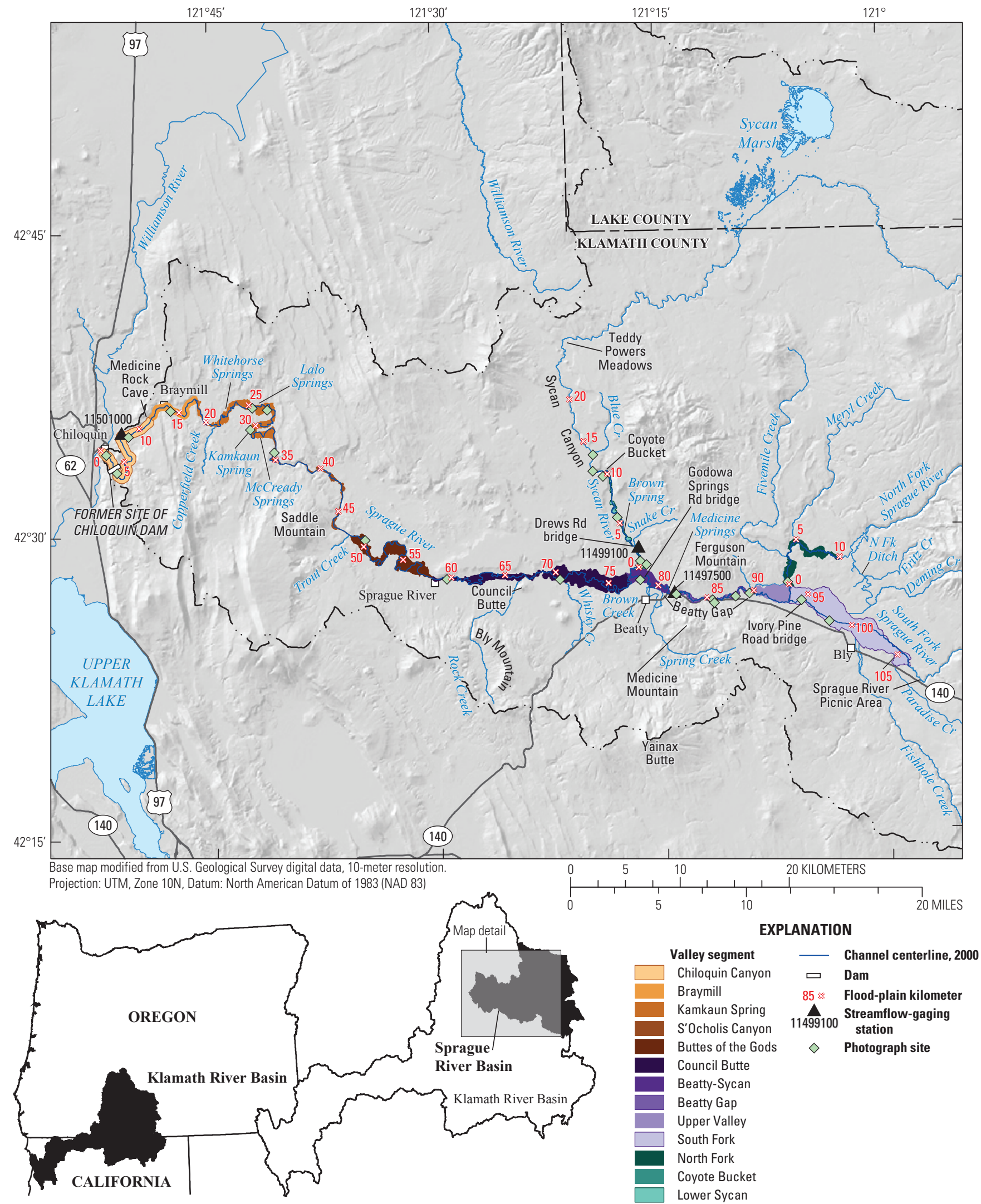

Figure 1. Valley segments in the study area, selected locations, and streamflow-gaging stations, Sprague River Basin, southcentral Oregon. 
This report describes all aspects of the study. Following short sections on background hydrology, physiography, and history of the Sprague River Basin, the overall methods and data sources underlying the analyses are briefly described. A section describing geomorphic surfaces and geologic history provides the basic physical framework of the study area, which is further elaborated in descriptions of the 13 individual valley segments that compose the study area. These descriptions are followed by the major substantive sections of the report: descriptions and analysis of physical flood-plain conditions and processes, and flood-plain and near-channel vegetation. For each of these substantive sections, the general progression is a description of the analyses (including methods) and observations, followed by more interpretative discussions of processes and conditions. Key findings are summarized at the end of both of these sections, which support a final section on implications for restoration and monitoring.

\section{Units of Measurement and Key Locations}

Analyses and results are in metric units. Conversions to English units are listed in the conversion table. Locations along the main-stem and South Fork Sprague River channel are referenced to river kilometers (RK) measured from the Sprague River mouth along the channel centerline mapped from 2000 aerial photographs. Similarly, Sycan River kilometers (SYRK) and North Fork Sprague River kilometers (NFRK) are measured from their confluences with the Sprague River along the 2000 channel centerline. To avoid ambiguity owing to channel shifting, especially for the historical analyses, most locations are referenced to flood-plain kilometers (FK; Sycan River flood-plain kilometer, SYFK; North Fork Sprague River flood-plain kilometer, NFFK) from centerlines bisecting the late Holocene flood plains for the Sprague River and its major tributaries (fig. 1). In 2000, the length of the channel of the main-stem Sprague River and its upstream continuation as the South Fork Sprague River was $150.9 \mathrm{~km}$ within a $106.2-\mathrm{km}$-long flood plain. Similarly, the Sycan River within its lower alluvial reach flowed for $16.1 \mathrm{~km}$ along an $11.3 \mathrm{~km}$ flood plain, and the North Fork Sprague River meanders for $15.6 \mathrm{~km}$ within a 9.8-km-long flood plain.

Prominent landmarks and key locations along the Sprague and South Fork Sprague Rivers (table 1) include the former location of Chiloquin Dam (RK 1.3, FK 1.3), USGS streamflow-gaging station 11501000 (RK 8.8, FK 8.3), Braymill (RK 13.3, FK 12.6), Kamkaun Spring (RK 37.0, FK 30.2), the town of Sprague River (RK 79.9, FK 58.1), Council Butte (RK 93.2, FK 66.4), Sycan River confluence with Sprague River (RK 111.8, FK 76.8), Beatty (RK 113.6, FK 78.2), Oregon Water Resources Department (OWRD) streamflow-gaging station 11497500 at Beatty Gap (RK 119.5, FK 81.4), North Fork Sprague River confluence with Sprague River (RK 135.8, FK 93.2), and Bly (RK 137.3, FK 94.3). Just outside the study area is the Sprague River Picnic Area on Highway 140 (about RK 152.3, about FK 107.6).
On the Sycan River, the Drews Road Bridge and OWRD streamflow-gaging station 11499100 are at SYRK 5.2 (SYFK 2.2), just downstream of the Snake Creek confluence (SYRK 5.4, SYFK 2.4). The Fivemile Creek confluence with the North Fork Sprague River is at NFRK 4.3 (NFFK 1.7).

\section{Sprague River Basin}

The Sprague River (fig. 1) drains $4,167 \mathrm{~km}^{2}$ of south-central Oregon before joining the Williamson River $17 \mathrm{~km}$ upstream of the Williamson River confluence with Upper Klamath Lake. The Sprague River contributes about 55 percent of the mean annual flow of the Williamson River at their confluence. The Sprague River begins at FK 93.2 (RK 136.1) with the confluence of the North Fork Sprague River (drainage area $759 \mathrm{~km}^{2}$ ) and South Fork Sprague River (drainage area $534 \mathrm{~km}^{2}$ ). From there, the Sprague River flows through alternating wide valleys and canyon reaches and joins the Williamson River at the town of Chiloquin. Primary tributaries to the Sprague River are the Sycan River at FK 76.8 (drainage area 1,447 $\mathrm{km}^{2}$ ) and Trout Creek at FK 48.0 (drainage area $71 \mathrm{~km}^{2}$ ). About one-half of the basin, including much of the headwaters and uplands, is within the Winema and Fremont National Forests. About 46 percent of the basin is privately owned, including much of the Sprague River flood plain and the lower reaches of the North Fork Sprague River, South Fork Sprague River, and Sycan River. In 1988, a 95-km reach of the Sycan River was designated as a Wild and Scenic River to a point $20 \mathrm{~km}$ upstream of its Sprague River confluence. Furthermore, the Gearhart Mountain Wilderness Area (not shown in fig. 1; east of location map) includes parts of the South Fork $\left(24 \mathrm{~km}^{2}\right)$ and North Fork $\left(44 \mathrm{~km}^{2}\right)$ Sprague River headwaters. The Sprague River Basin is within Klamath and Lake Counties. Primary towns within the basin are Chiloquin, Sprague River, Beatty, and Bly.

\section{Geography and Geology}

Within the northernmost extent of the Basin and Range physiographic province (Fenneman, 1931), the Sprague River Basin spans many uplifted ranges and volcanic centers separated by fault-bounded valleys. The basin margin includes Gearhart Mountain (2,549 m) west of Winter Rim (not shown in fig. 1; east of location map), which separates the Sprague River Basin from the closed Summer Lake basin to the northeast (east of area shown in fig. 1), and Yamsey Mountain $(2,498 \mathrm{~m})$ to the north (north of area shown in fig. 1), dividing the Sprague River Basin from the upper Williamson River. The southern basin margin is formed by lower ranges separating the Sprague River Basin from those of the Lost River and Goose Lake (not shown in fig. 1; part of the Sacramento River Basin). High points along the southern basin margin include Saddle Mountain (2,085 m), Bly Mountain (1,789 m), 
Table 1. Locations of notable features in the Sprague River study area, Oregon.

[Abbreviations: USGS, U.S. Geological Survey; OWRD, Oregon Water Resources Department; SYRK, Sycan river kilometer; SYFK, Sycan flood-plain kilometer; NFRK, North Fork Sprague river kilometer; NFFK, North Fork Sprague flood-plain kilometer]

\begin{tabular}{|c|c|c|}
\hline Location & $\begin{array}{c}\text { River } \\
\text { kilometer } \\
(2000)\end{array}$ & $\begin{array}{l}\text { Flood-plain } \\
\text { kilometer }\end{array}$ \\
\hline \multicolumn{3}{|c|}{ Sprague and South Fork Sprague Rivers } \\
\hline Sprague River confluence with Williamson River & 0.0 & 0.0 \\
\hline Former site of Chiloquin Dam & 1.3 & 1.3 \\
\hline USGS streamflow-gaging station 11501000 & 8.8 & 8.3 \\
\hline Chiloquin Ridge Road & 9.4 & 8.8 \\
\hline Braymill & 13.3 & 12.6 \\
\hline Sprague River Road bridge & 16.4 & 15.5 \\
\hline Whitehorse Springs & 24.8 & 22.0 \\
\hline Lalo Springs & 29.9 & 25.5 \\
\hline $\begin{array}{l}\text { McCready Ranch, former site of USGS streamflow-gaging } \\
\text { station } 11501000\end{array}$ & 34.4 & 28.6 \\
\hline Kamkaun Springs & 37.0 & 30.2 \\
\hline McCready Spring & 39.8 & 32.1 \\
\hline Sprague River Road bridge, S'Ocholis Canyon & 44.4 & 34.3 \\
\hline Lone Pine, Saddle Mountain Pit Road bridge & 52.0 & 40.7 \\
\hline Trout Creek confluence & 59.8 & 48.0 \\
\hline The town of Sprague River, Sprague River Road Bridge & 79.9 & 58.1 \\
\hline Council Butte & 93.2 & 66.4 \\
\hline Sycan River confluence with Sprague River & 111.8 & 76.8 \\
\hline Beatty, Godowa Springs Road bridge & 113.6 & 78.2 \\
\hline OWRD streamflow-gaging station 11497500 , Beatty Gap & 119.5 & 81.4 \\
\hline Railroad bridge, entrance to Beatty Gap & 118.8 & 80.9 \\
\hline North Fork Sprague River confluence with Sprague River & 136.1 & 93.2 \\
\hline Bly, Ivory Pine Road bridge & 137.3 & 94.3 \\
\hline Fish Hole Creek confluence & 143.0 & 100.1 \\
\hline Campbell Road bridge & 144.8 & 101.5 \\
\hline Sprague River picnic area ${ }^{1}$ & 152.3 & 107.6 \\
\hline \multicolumn{3}{|c|}{ Sycan and North Fork Sprague Rivers } \\
\hline $\begin{array}{l}\text { Drews Road bridge; OWRD streamflow-gaging station } \\
\quad 11499100\end{array}$ & SYRK 5.2 & SYFK 2.2 \\
\hline Snake Creek confluence with Sycan River & SYRK 5.4 & SYFK 2.4 \\
\hline Fivemile Creek confluence with North Fork Sprague River & NFRK 4.3 & NFFK 1.7 \\
\hline
\end{tabular}

${ }^{1}$ Sprague River picnic area is outside the study area, locations are approximate.

Yainax Butte (2,201 m), and Fishhole Mountain (2,154 m; east of area shown in fig. 1). The alluvial bottomlands flanking the Sprague River range from the 1,268-m-altitude confluence with the Williamson River to about $1,350 \mathrm{~m}$ in the broad valley upstream of the North and South Fork Sprague River confluence. The mean altitude of the basin is 1,600 m (Risley and others, 2008).

The Sprague River Basin is underlain by late Tertiary and Quaternary volcanic and sedimentary strata locally offset by north- to northwest-trending normal faults (Sherrod and Pickthorn, 1992; Jenks, 2007). The uplands are underlain chiefly by upper Miocene and Pliocene basalt and basaltic andesite lava flows issued from local vents and shield volcanoes, locally overlying older and more siliceous lava flows and domes. One of the younger basalt flows, the Basalt of Knot Tableland, flowed down the paleo Sycan River valley, partly filling and blocking the Sprague River Valley 3.0 \pm 0.9 million years ago (Ma; Sherrod and Pickthorn, 1992). Some of the prominent buttes within the Sprague River Valley, particularly near the town of Sprague River, are tuff cones formed by volcanic centers venting through lakes and wet lake sediment. 
The broad alluvial valleys of the Sprague River are excavated chiefly into weakly consolidated Miocene and Pliocene diatomites, mudstones, sandstones, conglomerates, and tuffs deposited in lake basins and broad valleys bounded by block-faulted uplifts or lava flows. Incision of the modern valleys probably began with integration of the Sprague River drainage with a Cascade-Range-bisecting Klamath River in the late Pliocene (Sherrod and Pickthorn, 1992). The present river winds westward through the fault-bounded uplifts and down-dropped basins, resulting in alternating narrow canyon and wide valley segments, before joining the Williamson River in the fault-bounded basin containing Upper Klamath Lake and the lower Williamson River.

The Sprague River Basin was affected greatly by the eruption of Mount Mazama that formed Crater Lake caldera about 7,700 calendar years before present (cal yr BP; Bacon, 1983; Bacon and Lanphere, 1990; Zdanowicz and others, 1999). The climactic eruption ejected 50 cubic kilometers $\left(\mathrm{km}^{3}\right)$ of dense rock equivalent, forming a widespread fallout tephra covering more than $1,000,000 \mathrm{~km}^{2}$ of western North America (Sarna-Wojcicki and Davis, 1991). Fallout tephra thicknesses exceed 1 meter (m) in the northwestern part of the Sprague River Basin (Sherrod and Pickthorn, 1992) but decrease to less than 1 centimeter $(\mathrm{cm})$ in the southern and eastern parts of the basin. In addition to hydrologic and vegetative effects (Newberry, 1857; Minckley and others, 2007; Cummings and Conaway, 2009), remobilization of the silt-to-granule-size pumice changed the character of the Sprague and Sycan Rivers and flood plains.

\section{Climate and Hydrology}

The Sprague River Basin is a high, semi-arid basin in the rain shadow of the southern Cascade Range. Mean annual precipitation ranges from less than $40 \mathrm{~cm}$ in the valley floors to $120 \mathrm{~cm}$ at the high-altitude basin margins (PRISM Climate Group, 2012). Average precipitation for 1971-2000 in the basin was $54 \mathrm{~cm}$ (Risley and others, 2008). Most precipitation falls between October and March, with about 30 percent of the precipitation falling as snow in the valleys and more than 50 percent falling as snow in the uplands (Connelly and Lyons, 2007; Rabe and Calonje, 2009).

Streamflow has been measured systematically by the USGS in the Sprague River Basin since 1912, with long-standing gaging stations operated by the USGS or Oregon Water Resources Department (OWRD) on the Sprague River near its confluence with the Williamson River (Sprague River near Chiloquin, 11501000), on the Sycan River near its confluence with the Sprague River (Sycan River below Snake Creek, 11499100), and on the Sprague River upstream of its confluence with the Sycan River (Sprague River near Beatty, 11497500). Isolated measurements were made at some locations early as 1904 (USGS Oregon Water Science Center, Portland, Oregon, measurement station records for station 11497500). At the most downstream gaging station near Chiloquin (which has a contributing area of $4,053 \mathrm{~km}^{2}, 97$ percent of the total basin area), annual flow for 1921-2008 varied greatly but averaged 16.4 cubic meters per second $\left(\mathrm{m}^{3} / \mathrm{s}\right)$ (fig. 2). For 1971-2000, the average flow was $18.0 \mathrm{~m}^{3} / \mathrm{s}$, equivalent to $13.8 \mathrm{~cm}$ of annual runoff from the basin and accounting for 25 percent of the average basin precipitation for that period. The average flow of $8.6 \mathrm{~m}^{3} / \mathrm{s}$ measured on the Sprague River near Beatty (11497500; 1954-2009 available record) and $4.2 \mathrm{~m}^{3} / \mathrm{s}$ measured on the Sycan River downstream of Snake Creek (11499100; 1974-2010 available record) account for about 80 percent of the total flow near Chiloquin.

Flows typically are greatest between December and June, representing seasonality in precipitation and snowmelt (fig. 3). Peak discharges affecting the lower river originate partly from snowmelt, with the largest peaks resulting from regional rain-on-snow events such as those in 1964, 1982, and 1987. These mainly occur between December and February. The $422 \mathrm{~m}^{3} / \mathrm{s}$ flow of December 26, 1964, measured at the gaging station near Chiloquin (11501000) is the largest known flow (fig. 2). Spring snowmelt peaks typically are smaller, but can be of longer duration, and generally occur during the March-June period of overall higher flows (fig. 3).

Analyses of regional temperature, precipitation, and Sprague River annual runoff (at the station near Chiloquin, 11501000) show no statistically significant temporal trends for records starting in the early 1900 s and extending through 1996 (Risley and Laenan, 1999). However, their analysis revealed changes in precipitation-runoff relations, particularly decreased runoff in relation to precipitation between 1930 and 1950, increased runoff between 1950 and 1980, and then stable or decreased runoff between 1980 and 1996. Because these changes did not relate to temporal trends in any assessed climate variables, Risley and Laenan (1999) suggested that land-use changes possibly affected basin hydrology, although they did not identify specific causes or activities.

Springs and spring complexes locally influence flow (Gannett and others, 2007), water temperature (Watershed Sciences, Inc., 2000), and flood-plain geomorphology and habitat conditions in the basin. Spring discharge accounts for more than 60 percent of the annual Sprague River flow near Chiloquin (Gannett and others, 2007). In particular, large spring complexes on or adjacent to the Sprague River flood plain in the reach between FK 22 and FK 32 (including Kamkaun Spring) and east of Beatty (FK 80 to FK 90) contribute about 31 percent of the annual flow (Gannett and others, 2007). Possibly because of modulated water temperatures and stable channel substrate conditions, these spring areas are abundantly used by fish, including redband trout (Oncorhynchus mykiss), sculpin (Cottidae), and suckers (Catostomidae; Ellsworth and others, 2007). Probably for similar reasons as well as access to fish, spring areas also have been areas of long-standing cultural occupations and use (Spier, 1930; Cressman and others, 1956; Jenkins and Connolly, 2007). 

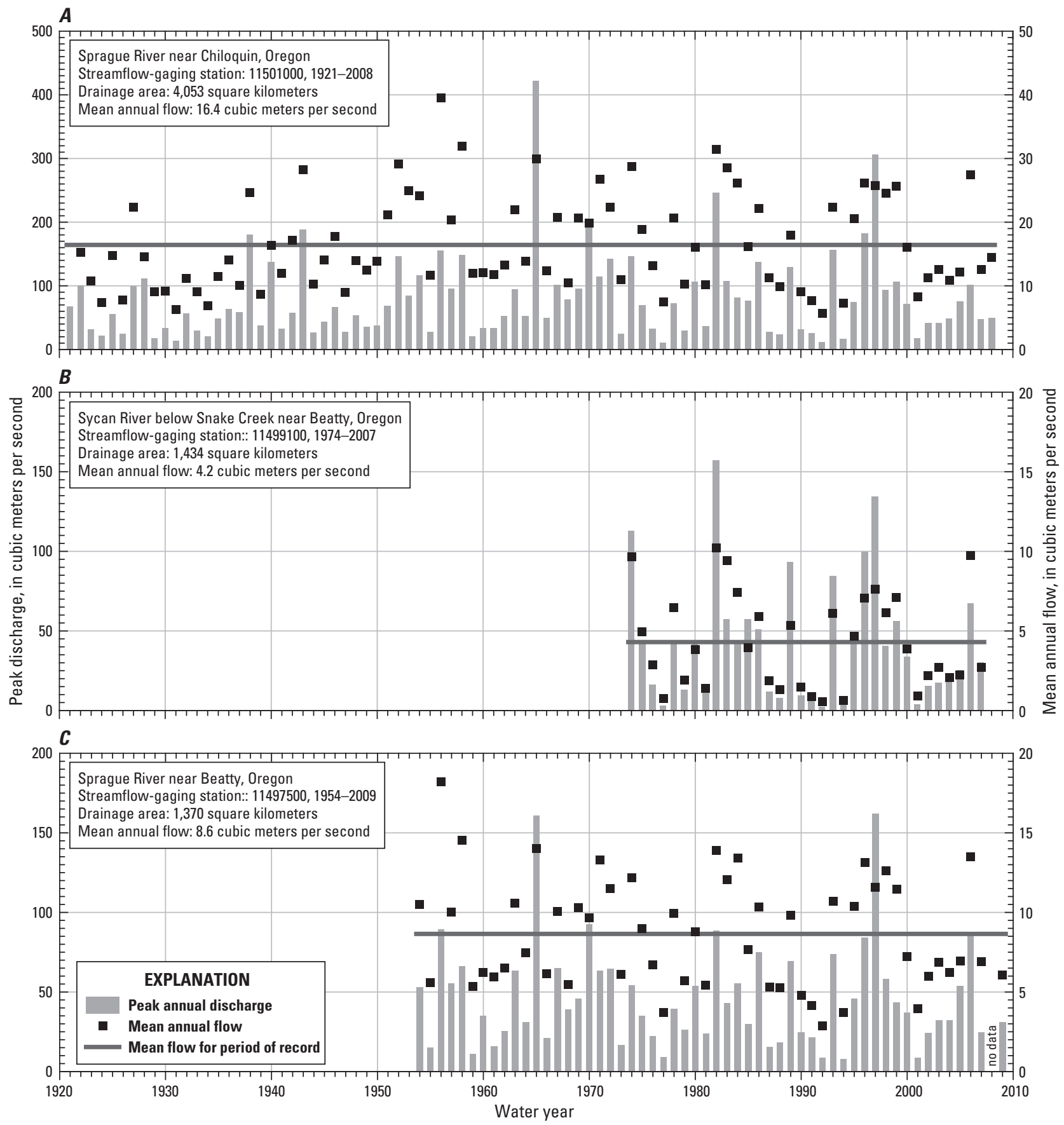

Figure 2. Annual peak discharge for streamflow-gaging stations at $(A)$ Sprague River near Chiloquin, station 11501000; (B) Sycan River below Snake Creek near Beatty, station 11499100; and (C) Sprague River near Beatty, station 11497500, Sprague River Basin, Oregon. 


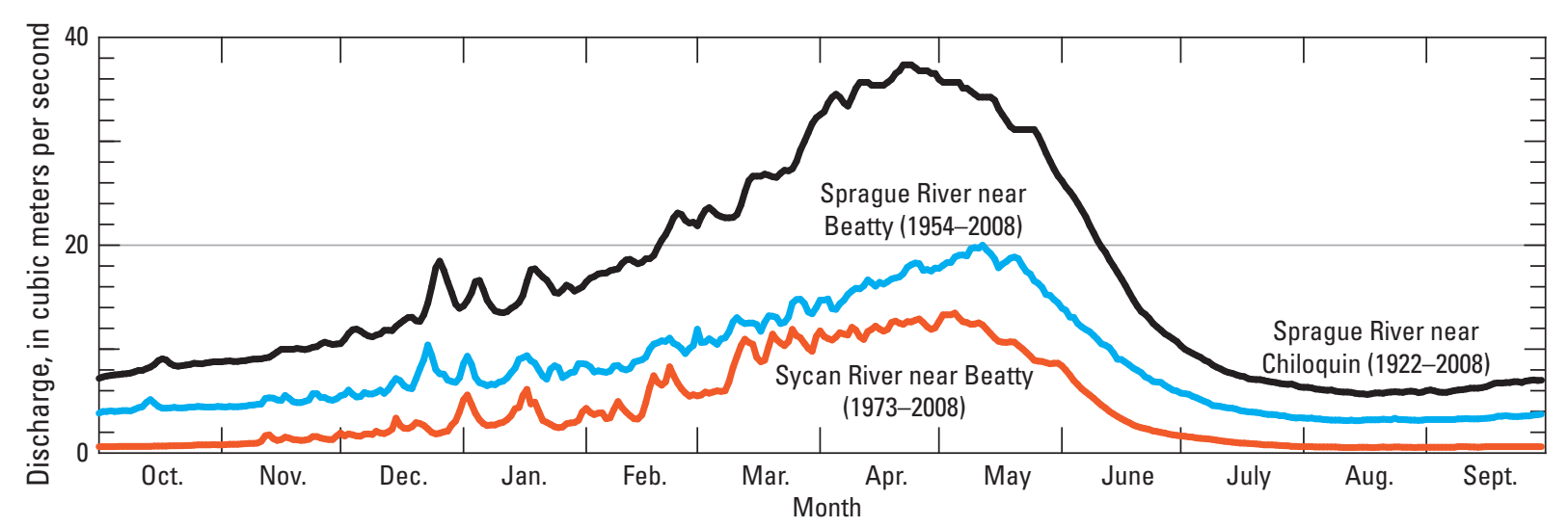

Figure 3. Mean daily discharge for selected streamflow-gaging stations, Sprague River Basin, Oregon.

\section{Vegetation}

As summarized by Connelly and Lyons (2007) and Rabe and Colonje (2009), the uplands of the Sprague River Basin are vegetated largely by mixed conifer forests dominated by ponderosa (Pinus ponderosa) and lodgepole pine (Pinus contorta). At lower and warmer altitudes, the conifer forests transition to sagebrush (Artemisia L.) steppe or sagebrush-juniper (Juniperus L.) woodlands. Valley bottoms and riparian corridors are vegetated with riparian shrublands, grassland meadows, wetland vegetation, and, in many locations, irrigated pasture grasses and hay. In some reaches, nonnative stands of reed canarygrass (Phalaris arundinacea) have colonized riparian areas. Detailed discussion of flood-plain and riparian vegetation and historical vegetation trends follows in the section, "Flood-Plain and Riparian Vegetation."

\section{Historical Human Influences and Land Use}

The Sprague River Basin has a long history of human use and settlement, starting with hunting, gathering, fishing, and habitation by Klamath, Modoc, and Yahooskin Native Americans. The high country of the basin was used for hunting and gathering during the summer, but the lower Sprague River Valley, particularly areas near the large spring complexes between FK 22.0 and FK 32.0, were important winter settlement sites since before the Mazama eruptions of 7,700 cal yr BP (Cressman and others, 1956). European exploration and settlement began with 1826 forays by fur trappers of the Hudson's Bay Company (Helfrich, 1974). The Klamath Indian Reservation was established in 1864, encompassing much of the Sprague River Basin west of the confluence of the North and South Forks of the Sprague River, and leading to the 1869 establishment of the Yainax sub-agency near the present town of Sprague River. Allotments to tribal members in conjunction with The General
Allotment (Dawes) Act of 1887 resulted in private ownership of much of the valley bottoms within the reservation boundary. In 1954, the Klamath Tribes were "terminated," with much of their unallocated land base becoming the Winema National Forest.

The main land uses in the basin have been livestock grazing and timber harvest, which began in the late 19th century and have continued at varying intensities to the present. Livestock was an economic mainstay for residents of the Sprague River Basin in the late 19th and early 20th centuries, resulting in widespread overgrazing by 1907 (Connelly and Lyons, 2007, p. 2-5). Livestock was supported partly by irrigated hay and forage production in the valley bottoms, leading to digging of diversion ditches and temporary dams along the Sprague River starting as early as 1890 (Helfrich, 1974).

The timber industry lagged slightly behind the livestock industry, awaiting the linkage of the Southern Pacific Railroad between California and Chiloquin in 1911, and then the completion of the Oregon, California, and Eastern (OC\&E) Railroad from Chiloquin to Bly in 1928 (Helfrich, 1974). This railroad network aided harvest of the massive stands of ponderosa pine in the uplands of the Sprague River and surrounding basins. During the first half of the 20th century, many mills operated along the Sprague River from Bly to Chiloquin, with logs and lumber transported by rail and river. Timber production in the basin has declined significantly since the 1950s, with all mills closed since then and the railroad grade converted to the OC\&E Trail operated by Oregon State Parks.

Presently, agriculture, livestock raising, and timber management remain as the primary land uses within the Sprague River Basin, although at decreased intensities. Forest management now focuses more on improving forest health. Agriculture is concentrated within the wide alluvial basins and is almost all pasture and hay fields, supporting ongoing livestock operations. 


\section{Study Area, Methods, and Data Sources}

Analyses were based on integrated consideration of geologic and geomorphic setting, historical observations, and current conditions and processes. The approach was multifaceted, relying on mapping and stratigraphic analysis of flood-plain deposits and flanking features; evaluation of historical records and observations; systematic mapping and analysis of flood-plain and channel characteristics (including morphologic and vegetation conditions) from historical surveys, maps, and aerial photographs; and a 2006 survey of depositional features left by early 2006 high flows. This section provides a synopsis of the study area and analysis framework, including general methods and source data. Descriptions of the specific methods and analyses are provided in subsequent sections that detail the geomorphic mapping and valley segment delineation, physical channel and flood-plain processes, and flood-plain and riparian vegetation.

\section{Study Area}

This study focused on the lower, alluvial segments of the Sprague River system, including the lower parts of the Sycan River, North Fork Sprague River, South Fork Sprague River, and the entire $136.1 \mathrm{~km}$ of the Sprague River between the confluence of the North and South Forks and the Sprague River confluence with the Williamson River at Chiloquin (fig. 1). Analysis of the Sycan River focused on the lowermost $11.3 \mathrm{~km}$ downstream of its emergence from the Sycan Canyon near Coyote Bucket.

Analyses concentrated on the channel and flood plain within an area mapped and defined as the "geomorphic flood plain" of the main-stem Sprague River and the lower alluvial portions of the three major tributaries. As described in more detail in the section, "Geomorphic History", the geomorphic flood plain (pl. 1) was mapped on the basis of topography and existing soils information (Cahoon, 1985), supported by field and stratigraphic observations.

For many analyses, results and inferences were stratified by 13 valley segments subdivided from the geomorphic flood plain on the basis of valley form and major tributary junctions (table 2; fig. 1). These segments included nine encompassing the $136.1 \mathrm{~km}$ of main-stem Sprague River, two for the lower Sycan River, and one segment each for the South Fork Sprague and North Fork Sprague Rivers within the study area. Segment lengths (as measured along flood-plain centerline) ranged from 3.6 to $18.8 \mathrm{~km}$.

\section{Geomorphic Mapping}

Geomorphic mapping establishes the basic context for understanding modern channel conditions by defining major elements of late Cenozoic geologic history shaping the geomorphology of the study area and outlining the geomorphic flood plain, which is the spatial domain for assessing channel change and vegetation conditions in the flood plain. Additionally, the process of defining and mapping valley-bottom landforms substantially aids in identifying key flood-plain and channel processes (for example, Coffman and others, 2011, Simenstad and others, 2011). The mapping domain broadly corresponds with the extent of lidar topography acquired in November 2004 (Watershed Sciences, Inc., 2005) and includes the main-stem Sycan, Sprague, and North Fork Rivers within the broad alluvial valleys. The mapping encompasses the main flood plains and contiguous alluvial and colluvial landforms (pl. 1). The geomorphic mapping was based on aerial photographs, the 2004 lidar data, U.S. Geological Survey 7.5-minute topographic maps, existing soil mapping (Cahoon, 1985), reconnaissance field observations, and stratigraphic sections, primarily along bank exposures but supplemented by augering. Linework was digitized at scales ranging from 1:5,000 to 1:10,000, using the 2004 lidar data as a base.

\section{Stratigraphic Studies}

Along with the geomorphic mapping, stratigraphic studies revealed conditions and processes prior to 20th-century historical records. Stratigraphic sections measured at cut banks along the main-stem Sprague River and all major tributaries (appendix A) enabled documentation of depositional environments and changes in channel and flood-plain materials, mainly for the last 10,000 years. Additionally, augering transects provided information on the distribution of specific deposits, such as those from the Sycan flood of about 7,500 years ago (Lind, 2009), as well as documentation of the altitude and age of paleochannel positions for the last 3,500 years. Stratigraphic measurements and descriptions at streamside exposures and from the augering transects included characterization of major depositional units, their sedimentary structures and textures, the nature of contacts between units, pedogenic alteration and bioturbation, and interpretation of the depositional environment. Deposit chronology was by radiocarbon dating of detrital and in-place organic materials (appendix B). Additionally, three samples of volcanic materials were submitted for identification (appendix C). At some sites, analysis of Cesium-137 content allowed determination of deposits emplaced after widespread above-ground nuclear testing in the 1950s (appendix D). 


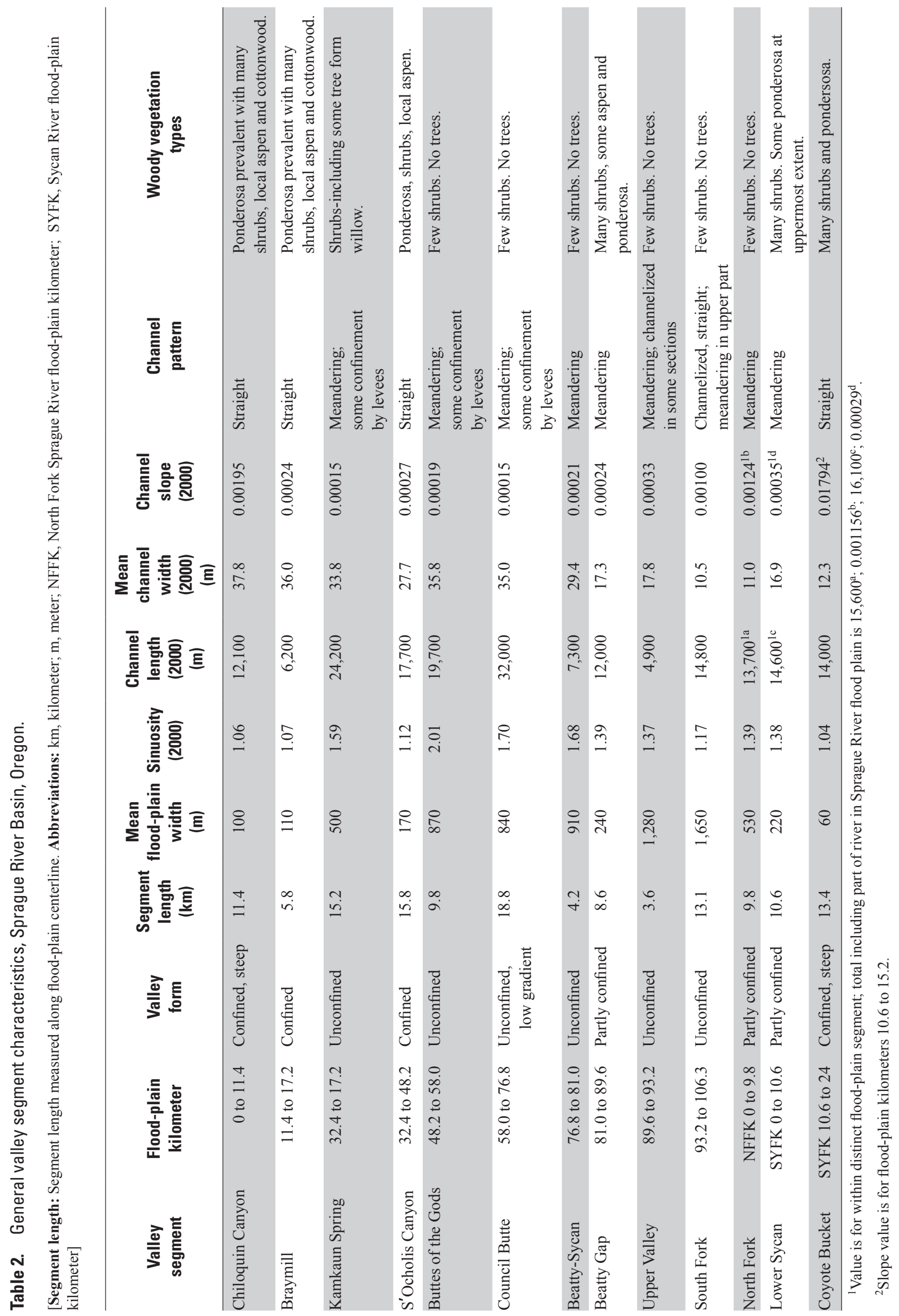




\section{Historical Observations and Photographs}

Early written accounts of channel and flood-plain conditions are sparse because the Sprague River Basin was not near major exploration and transportation routes. Aside from the General Land Office (GLO) surveys, the earliest accounts documenting channel and flood-plain conditions are from the early 1900s. These accounts include a land classification and timber survey of the Klamath Quadrangle (Leiberg, 1903; includes the study area west of FK 91.8), a preliminary report on water resources for the Klamath Indian Reservation (Henshaw, 1912), and field notes of botanist W.E. Lawrence summarizing observations in July 1922 and July 1934 (W.E. Lawrence, Oregon State University Herbarium, Corvallis, Oregon, unpublished field journals).

Early USGS records of streamflow measurement and related activities document channel and flow conditions as well as anecdotally describe diversions and log-driving activities on the Sprague River. In particular, station notes and photographs provided evidence of channel conditions dating back to 1904 for USGS streamflow measurement sites on the South Fork Sprague River near Bly, North Fork Sprague River near Bly, Fivemile Creek near Bly, Sprague River near Beatty, Sycan River near Beatty, and Sprague River near Chiloquin (streamflow-gaging station records available at U.S. Geological Survey, Oregon Water Science Center, Portland, Oregon). The most extensive accounts are for the period between 1912 and 1930 .

Evidence for decreased beaver (Castor canadensis), otter (Lutrinae Bonaparte), and muskrat (Ondatra zibethicus) populations also is recorded in some of the streamflow-gaging station records (U.S. Geological Survey, Oregon Water Science Center, Portland, Oregon) as well as in 1939-43 correspondence archived from Klamath Agency files (Larry Dunsmoor, Klamath Indian Nation, written commun., 2006). U.S. Army Corp of Engineers and related Klamath County memoranda from the 1960s through the 1990s document levee construction and damage (Klamath County, written commun., 2008).

\section{Nineteenth-Century Cadastral Surveys}

The first systematic surveys in the Sprague River Basin were the cadastral surveys by the U.S. General Land Office (GLO; succeeded by the Bureau of Land Management). The study area was surveyed in several different contracts spanning 1865-92 (table 3). Township boundaries and subdivisions for most of the main-stem Sprague River were surveyed between 1866 and 1872. However, subdivisions for parts of the Braymill, Coyote Bucket, and Chiloquin Canyon segments were first surveyed in 1892.
The GLO surveys entailed laying out townships of 36 sections, each of which was one square mile. The exterior boundaries of the townships and interior section lines (subdivisions) were established by surveying along lines running north-south and east-west. Where these lines cross rivers, the location (relative to monumented section corners) and width of the river were recorded in the accompanying GLO field notes. Although the resulting township maps show continuous channels, the river was surveyed only at the section and township boundary lines, with the course between lines estimated by the cartographer. Later, for some townships, riverbank lines were surveyed (termed "meandering"). This was done for parts of three townships within the Sprague River study area between 1871 and 1872 (35S 7E, 36S 11E, and 36S 12E; table 3). These meander surveys provided more complete information on the channel path between section lines; however, because these surveys typically followed the edge of the bank rather than the edge of the water, it is unclear whether they closely delimited the wetted channel. Consequently, width analyses based on the GLO surveys chiefly are based on the widths determined from the boundary and section line surveys as recorded in the GLO field notes, although the meander surveys were digitized from the maps and used for some channel planform analyses.

\section{Aerial Photographs}

The earliest aerial photographs available for the Sprague River system were acquired in 1940-41 (described hereafter as "the 1940 photographs"). These photographs, as well as aerial photographs from 1968 and 2000, served as the primary basis for mapping river and flood-plain conditions for different times during the 20th century (table 4). For the 1940 and 1968 aerial photographs, contact print photographs were scanned, rectified, georeferenced, and mosaicked following the methods of Hughes and others (2006), to create digital imagery with resolution of 1-m pixels. The 2000 imagery was available as digital orthophotograph quadrangles from the U.S. Geological Survey. The 1940 aerial photographs cover most but not all of the study area, extending to FK 95.2 on the South Fork Sprague River, NFFK 5.8 on the North Fork Sprague River, and SYFK 13.6 on the Sycan River. Therefore, for some analyses, parts of these upstream areas are not included. Secondary photographic sources included 1975 USGS orthoimagery and 2005 digital orthophotographs from the U.S. Dept. of Agriculture (table 4). 


\section{Geomorphology and Flood-Plain Vegetation of the Sprague and Lower Sycan Rivers, Klamath Basin, Oregon}

Table 3. Early (1865-92) General Land Office surveys in the Sprague River study area, Oregon.

[Township and range: S, south; E, east. Abbreviations: FK, flood-plain kilometer; NFFK, North Fork Sprague River flood-plain kilometer SYFK, Sycan River flood-plain kilometer; NA, not applicable]

\begin{tabular}{|c|c|c|c|c|c|c|}
\hline Township & Range & $\begin{array}{l}\text { Valley } \\
\text { segment }\end{array}$ & $\begin{array}{l}\text { Flood-plain } \\
\text { kilometer }\end{array}$ & $\begin{array}{c}\text { First } \\
\text { surveyed }\end{array}$ & $\begin{array}{l}\text { Subdivision survey } \\
\text { date(s) }\end{array}$ & Meander survey \\
\hline $35 \mathrm{~S}$ & $7 \mathrm{E}$ & Chiloquin Canyon & 0 to 6.9 & 1871 & $11-04-1871$ to $07-19-1872$ & $\begin{array}{l}\text { Right bank from FK } 9 \text { to } 0 \\
\text { (in section 3) meandered } \\
11-04-1871 \text { to } 07-19-1872\end{array}$ \\
\hline $34 \mathrm{~S}$ & $7 \mathrm{E}$ & Chiloquin Canyon & 6.9 to 11.2 & 1871 & ${ }^{1} 09-07-1871$ & NA \\
\hline $34 \mathrm{~S}$ & $8 \mathrm{E}$ & $\begin{array}{l}\text { Chiloquin Canyon; } \\
\text { Braymill; Kamkaun } \\
\text { Spring }\end{array}$ & $\begin{array}{l}11.2 \text { to } 25.4 \\
30.1 \text { to } 30.6\end{array}$ & 1869 & $11-13$ to $11-25-1892$ & NA \\
\hline $34 \mathrm{~S}$ & $9 \mathrm{E}$ & $\begin{array}{l}\text { Kamkaun Spring, } \\
\text { S'Ocholis Canyon }\end{array}$ & $\begin{array}{l}25.4 \text { to } 30.1 \\
30.6 \text { to } 33.2\end{array}$ & 1869 & $07-31$ to $08-18-1869$ & NA \\
\hline $35 \mathrm{~S}$ & $9 \mathrm{E}$ & $\begin{array}{l}\text { S'Ocholis Canyon, } \\
\text { Buttes of the Gods }\end{array}$ & 33.2 to 49.4 & 1866 & Completed 10-10-1866 & NA \\
\hline $35 \mathrm{~S}$ & $10 \mathrm{E}$ & Buttes of the Gods & $\begin{array}{l}49.4 \text { to } 50.2 \\
52.8 \text { to } 54.0\end{array}$ & 1866 & Completed 10-03-1866 & NA \\
\hline $36 \mathrm{~S}$ & $10 \mathrm{E}$ & $\begin{array}{l}\text { Buttes of the Gods; } \\
\text { Council Butte }\end{array}$ & $\begin{array}{l}50.2 \text { to } 52.8 \\
54.0 \text { to } 61.4\end{array}$ & 1866 & Completed 10-16-1866 & NA \\
\hline $36 \mathrm{~S}$ & $11 \mathrm{E}$ & Council Butte & 61.4 to 71.6 & 1866 & Completed 10-08-1866 & $\begin{array}{l}\text { Left bank meandered } \\
07-27-1872 \text { to } 08-08-1872\end{array}$ \\
\hline $36 \mathrm{~S}$ & $12 \mathrm{E}$ & $\begin{array}{l}\text { Council Butte, } \\
\text { Beatty-Sycan, } \\
\text { Beatty Gap, } \\
\text { Lower Sycan }\end{array}$ & $\begin{array}{l}71.6 \text { to } 81.9 \\
\text { SYFK } 0 \text { to } 2.2\end{array}$ & 1866 & Completed 10-27-1866 & $\begin{array}{l}\text { Left bank meandered } \\
08-09-1872 \text { to } 08-15-1872\end{array}$ \\
\hline $36 \mathrm{~S}$ & $13 \mathrm{E}$ & $\begin{array}{l}\text { Beatty Gap, } \\
\text { Upper Valley }\end{array}$ & 81.9 to 92.6 & 1865 & Completed 08-30-1865 & NA \\
\hline $36 \mathrm{~S}$ & $14 \mathrm{E}$ & $\begin{array}{l}\text { Upper Valley, South } \\
\text { Fork, North Fork }\end{array}$ & $\begin{array}{l}92.6 \text { to } 104.0 \text {; } \\
\text { NFFK } 0 \text { to } 4.2 \text { and } \\
5.4 \text { to } 9.8\end{array}$ & 1866 & Completed 09-05-1866 & NA \\
\hline $37 \mathrm{~S}$ & $15 \mathrm{E}$ & South Fork & 104.0 to 106.3 & 1866 & Completed 09-22-1866 & NA \\
\hline $35 \mathrm{~S}$ & $14 \mathrm{E}$ & North Fork & NFFK 4.2 to 5.4 & 1866 & Completed 09-01-1866 & NA \\
\hline $35 \mathrm{~S}$ & $12 \mathrm{E}$ & $\begin{array}{l}\text { Lower Sycan, } \\
\text { Coyote Bucket }\end{array}$ & SYFK 2.2 to 24 & 1866 & Completed 09-19-1866 & NA \\
\hline
\end{tabular}

${ }^{1}$ Contract date, plat approved 11-06-1872. 


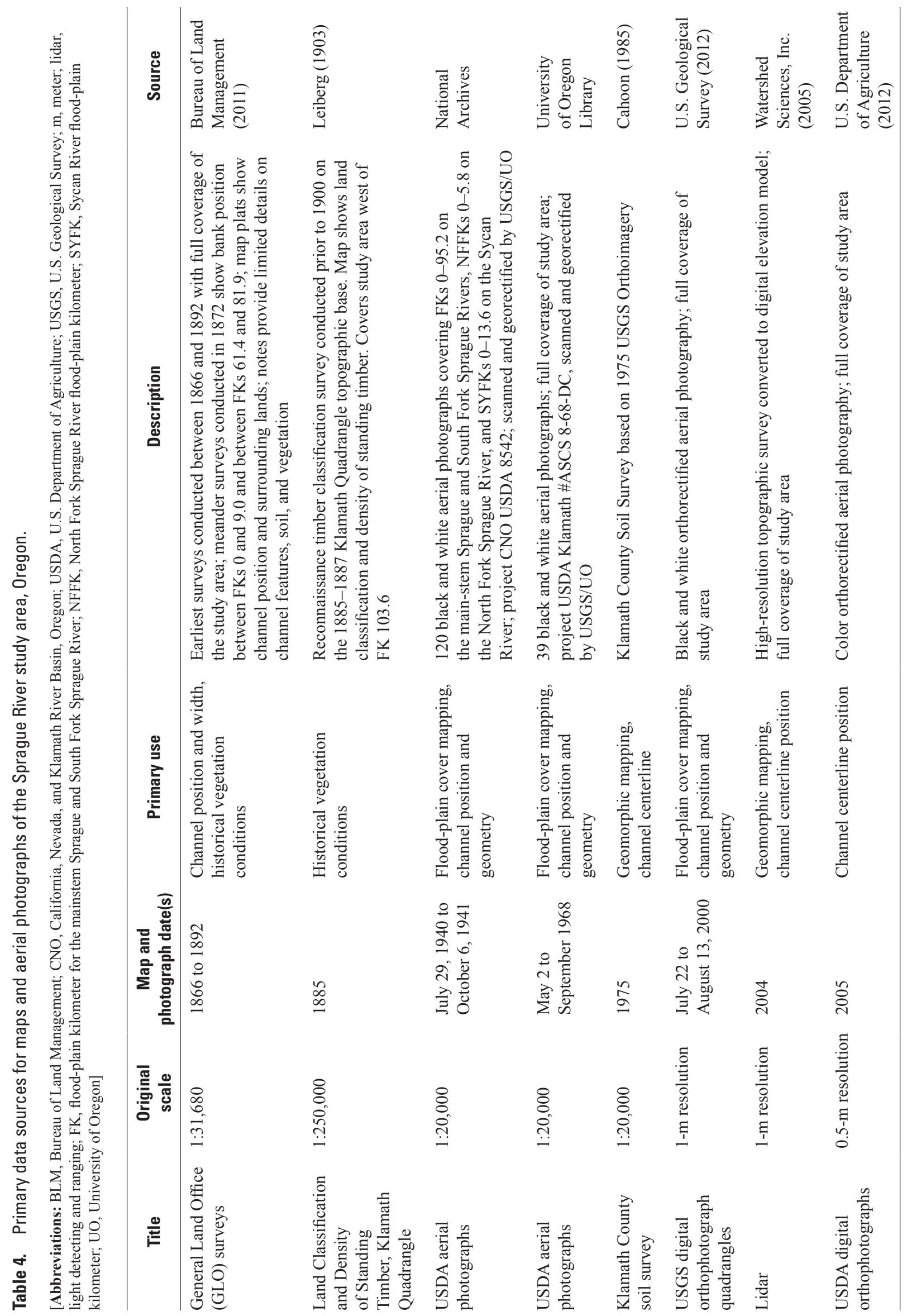




\section{Lidar Topography}

A lidar dataset covering most of the flood plain of the main-stem Sprague River, North Fork Sprague River, South Fork Sprague River, and lower Sycan River provided highresolution topography data. This lidar also was the basis for the geomorphic mapping. The lidar data were collected in November 2004 and represent normal autumn low-flow conditions (Watershed Sciences, Inc., 2005). The absolute vertical accuracy of the lidar point data is $0.052 \mathrm{~m}$ deviation root mean square error, 0.051-m standard deviation, $0.032-\mathrm{m}$ median (50th percentile) absolute deviation, and $0.1057-\mathrm{m}$ 95 th percentile absolute deviation. We worked with a gridded altitude dataset with 1-m spacing developed from the point data.

\section{Survey of Effects of 2006 High Flows}

High flows in winter and spring of water year (WY) 2006 (October 1, 2005-September 30, 2006) aided investigation of depositional patterns associated with geomorphically effective flows. Between June 23 and July 15, 2006, deposit thickness, texture, and altitude were measured at 71 locations along the main-stem Sprague River, from FK 93.2 just downstream of the confluence of the North and South Forks of the Sprague River, to FK 17.2 at the upstream end of the Braymill segment. These measurements documented the distribution and texture of flood deposits, as well as their distribution and characteristics relative to flood-plain landforms.

\section{Mapping and GIS Analysis Framework}

Geomorphic features, vegetation classes, and cultural (built) features within the geomorphic flood plain were mapped from the rectified and mosaicked aerial photographic sets (table 5). All features for most of the study area were mapped from the 1940, 1968, and 2000 aerial photographs. The 1940 aerial photographs, however, did not completely cover the upstream parts of the South Fork Sprague River (upstream of FK 95.2), North Fork Sprague River (upstream of NFFK 5.8), and Sycan River (upstream of SYFK 13.6). Supplemental maps of channel the centerline position were obtained from 1975 USGS imagery forming the basis of a 1977 soil survey (Cahoon, 1985), the 2004 lidar data, and 2005 USGS digital orthophotographs (table 4). These flood-plain features were digitized on screen at scale of 1:2,000, although finer-resolution inspection and field checking were required for identification and confirmation of some mapping classes and boundaries.

The water surface and any exposed bars were mapped, as visible on each aerial photograph. The Sprague River channel has well defined, steep banks, and there is no evident active channel extending beyond the water and bar surfaces in most locations. Exposed bars are rare and add only a small area to
Table 5. Features mapped from the 1940, 1968, and 2000 aerial photography in the geomorphic flood plain, Sprague River study area, Oregon.

[For each of the Physical Flood Plain and Cover Class themes, mapped features cover the entire geomorphic flood plain with no overlap. For the Anthropogenic theme, features were mapped only where present. Sprague River basin GIS data are available at http://water.usgs.gov/GIS/metadata/ usgswrd/XML/sprague river oregon_geomorphology.xml]

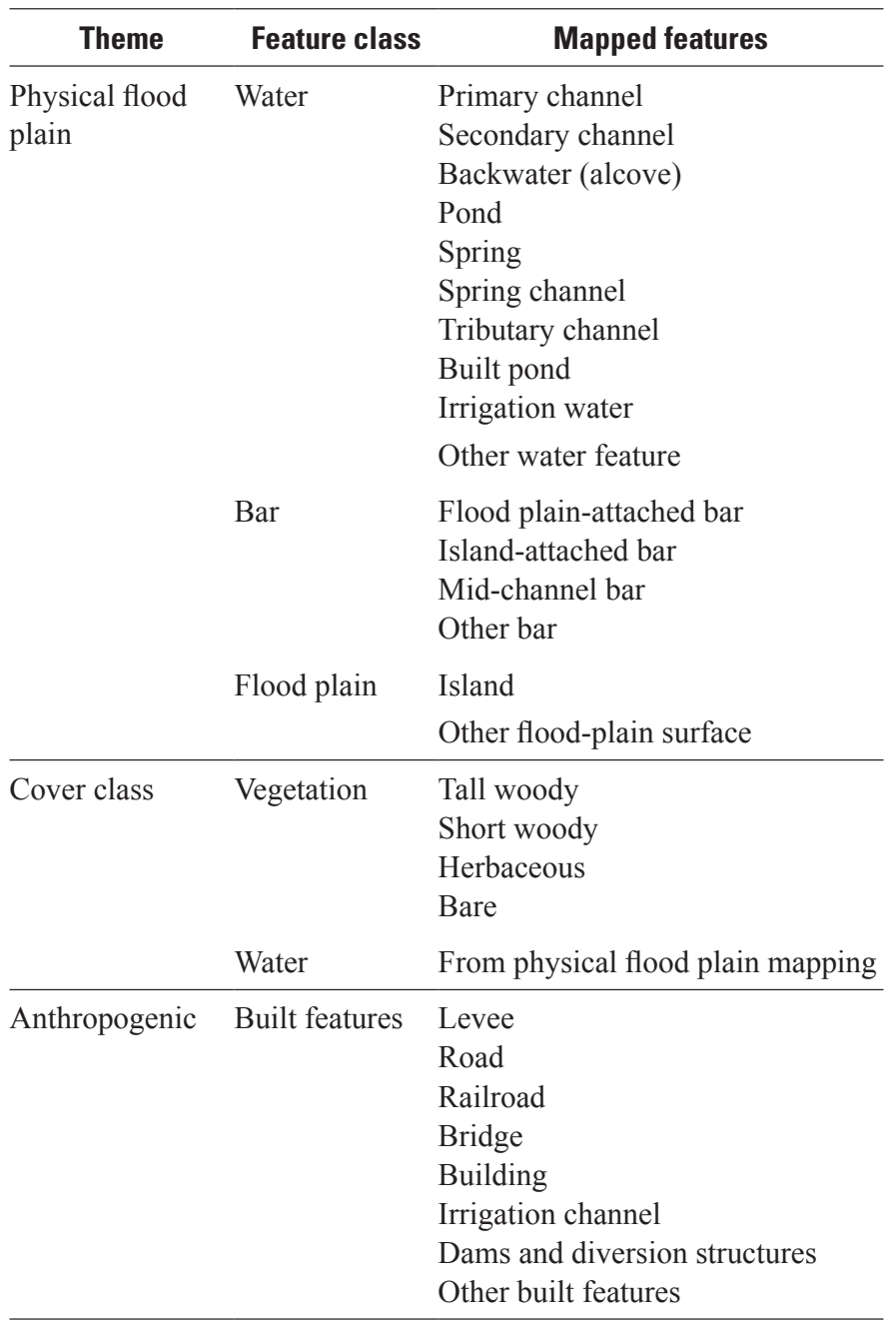

the overall channel area. Therefore, in analyzing channel width and area, the extent of water was used to represent the channel.

All map data were compiled into a geodatabase for analysis (U.S. Geological Survey, 2013). Aside from the broadscale geomorphic surface mapping, the analysis domain was restricted to the geomorphic flood plains of the Sprague River, and the Sycan, North Fork Sprague, and South Fork Sprague Rivers within the study area. Spatial and temporal metrics of channel and flood-plain characteristics were assessed by segment and more continuously by adopting measurement frameworks based on channel and flood-plain centerlines, following the approach of O'Connor and others (2003c). 
A flood-plain centerline frame of reference, which was static for the entire analysis period, simplified comparison among different years and was used to evaluate overall flood-plain characteristics and channel migration rates. Channel centerlines were mapped for each source dataset and were the basis for determining channel migration rates as well as providing a frame of reference for measuring channel characteristics such as width, bar frequency, and near-channel riparian conditions. For both the flood-plain and channel centerline reference frames, intersection points were created along the centerline at 200-m spacing. At each intersection point, transects perpendicular to the centerline were defined, and measurements were extracted from points along the transect line or, for some attributes, from flood-plain polygons within the area defined by adjacent transect lines and the geomorphic flood-plain boundary. These flood-plain polygons were used to assess areas of sand and gravel bars, water surface, vegetation types, and other flood-plain attributes. The flood-plain transects extended to the limits of the geomorphic flood plain. The channel transects extended $50 \mathrm{~m}$ in each direction from the channel centerline. To simplify analysis, the flood-plain centerline was smoothed in highly sinuous valley sections so that the resulting transects did not cross each other. No such smoothing was conducted for the channel centerlines.

\section{Geomorphic Mapping and Geologic History}

The geologic and geomorphic history creates the physical template for modern fluvial and ecologic processes. For the Sprague River study area, the Tertiary and Quaternary history of volcanic activity, basin-and-range faulting, and river integration and incision has established the overall geometry of the basin and produced alternating canyon and wide-valley reaches. Quaternary downcutting and lateral migration have left terraces and abandoned alluvial fans bounding the active flood plain, particularly in the broad alluvial valleys (pl. 1). Additionally, the flood plain and adjacent landforms have been affected by specific events during the late Holocene (such as the Mazama eruption and the ensuing delivery of substantial sand-size pumiceous sediment to the Sprague and Sycan Rivers), as well as more continuous flood-plain and channel processes, such as channel migration and avulsion, and flood-plain accretion and erosion.

\section{Geomorphic Units}

The area of mapping (pl. 1) was composed of the broad alluvial basins and contiguous fluvial and colluvial landforms flanking the Sprague River and the lower parts of the North Fork Sprague River, South Fork Sprague River, and the Sycan River. Within this area, which closely corresponds to the extent of the lidar coverage, 12 fundamental map units were defined (pl. 1; appendix E), representing present and past geomorphic environments and events. These landforms - including bedrock (undifferentiated), active and inactive alluvial fans, colluvial slopes, alluvial terraces, spring complexes, tributary and main-channel flood plains, and valley-fill surfaces - are mapped without specific regard to their constituent deposits, which distinguishes this map from typical geological maps. This is especially the case for the terraces and inactive alluvial fans, where alluvial processes have eroded older geologic units, primarily Tertiary lacustrine sediment, leaving landforms with thin and locally discontinuous caps of alluvial gravel.

\section{Undifferentiated Bedrock}

Irregular, typically hummocky or steep topography, underlain by Tertiary lacustrine sediment or volcanic rocks was mapped as undifferentiated bedrock. This map unit was defined only where completely surrounded by mapped alluvial or colluvial surfaces.

\section{Landslide Deposits}

Arcuate scarps bounding steep, hummocky topography indicate landslide masses. A few landslides are evident in the Chiloquin Canyon segment and in the Coyote Bucket segment of the Sycan Canyon. The Sycan Canyon landslides likely blocked the channel, resulting in the affected stream reaches traversing accumulations of large blocks of volcanic rock fallen from the canyon rim.

\section{Colluvial Slopes}

Steep but smooth slopes of as much as about 35 degrees, underlain by unconsolidated regolith, are formed by gravitational and alluvial transport processes such as rockfall, avalanching, biogenic (caused by living organisms) disturbance, and sheet-wash transport. Colluvial slopes typically head at steep bedrock outcrops, which are the source of material, and transition downslope to alluvial transport surfaces. Colluvium locally is an important source of coarse (gravel-size) material for the Sprague and Sycan Rivers, especially in canyon segments, where much of the flood plain is bordered by colluvium or bedrock. The distinction of colluvial slopes and active tributary fans is locally arbitrary, but tributary fans typically have slopes of less than 10 degrees.

\section{Abandoned Fans}

Incised, shallowly sloping (less than 10 degrees) alluvial transport surfaces descend toward the Sprague River Valley, especially along the southern valley margin between the towns 
of Sprague River and Bly. Locally, abandoned fan surfaces are labeled 1 through 4 on plate 1 on the basis of increasing degree of incision (and presumably age). The older surfaces only have isolated remnants of original transport surfaces composed of fluvial gravel, and are separated from younger (and lower) fan and tributary surfaces by slopes formed in the underlying Tertiary lacustrine sediment. Some abandoned fan surfaces, such as those south of the Sprague River Valley near Bly, are formed partly of pumiceous pyroclastic flow deposits derived from Tertiary volcanic centers to the south (Sherrod and Pickthorn, 1992). Near the Sprague and Sycan Rivers, tributary fan deposits locally are interbedded with main-stem fluvial channel and overbank deposits (for example, section 6/28/08-1; fig. 4). Primary soil taxonomic classes on abandoned fan surfaces include Haploxerolls, Argixerolls, and Durixerolls, denoting minor-to-significant accumulations of clays, silica, and carbonate. The ages of these surfaces likely range from Pliocene (but probably post-dating the 3.0 $\pm 0.9 \mathrm{Ma}$ Basalt of Knot Tableland) to perhaps as recent as early Holocene. Where the capping gravel is intact, the abandoned fans largely are stable features that contribute little sediment directly to the modern fluvial system. The sequence of abandoned alluvial fan surfaces indicate overall Tertiary and Quaternary incision of the Sprague River Valley, probably in conjunction with integration and incision of the Sprague River through fault-uplifted canyon segments downstream.

\section{Active Tributary Fans}

Shallowly sloping (less than 10 degrees) alluvial transport surfaces grade to modern main-stem and tributary flood plains, commonly with a singular or composite fan-shaped down-gradient termini. These are active alluvial transport surfaces heading from confined tributaries, colluvial slopes, and bedrock, formed where flow routes expand onto flat terraces, flood plains, and other flat bottomland surfaces. These surfaces commonly are gradational with colluvial slopes and valley bottomlands, but with intermediate slopes. Soils on active fan surfaces are Haploxerolls, Cryorthents, Cryofluvents, Cryoborolls, and Cryaquepts taxonomic classes, all of which only have incipient horizon development in the form of translocated and accumulated carbonates and silica consistent with late Pleistocene to Holocene ages. Many active fans have surfaces post-dating the 7,700 cal yr BP Mazama eruption. Active fans episodically provide sediment to the main-stem rivers and flood plains.

\section{Terraces}

Planar alluvial surfaces as much as $50 \mathrm{~m}$ higher than the active flood plain flank the Sprague River near its confluence with the Williamson River. Similarly, terraces at several altitudes of as much as $20 \mathrm{~m}$ higher than the active flood plain border the Sprague River downstream of the town of Sprague
River (pl. 1). Upstream, isolated low terraces flank the Sprague River near Beatty Gap and along the lower Sycan River. The terrace surfaces are underlain by fluvial gravel, sand, and silt, and generally are stable features upon which Haploxeroll soils have formed, characterized by cambic B horizons and some carbonate accumulation (U.S. Department of Agriculture, 1975). Terrace risers locally expose Tertiary lacustrine sediment or other bedrock units, indicating that at least some of the terraces are strath surfaces cut into the soft Tertiary sediment (for example, section 6/28/05-1; fig. 4). The positions and degree of soil development are consistent with ages of late Tertiary through Quaternary. All these terraces apparently pre-date the 7,700 cal yr BP Mazama eruption, judging from the presence of Mazama fallout tephra in the upper parts of their soil profiles (Cahoon, 1985). Like the abandoned alluvial fans, the terraces owe to episodic filling and incision during Quaternary downcutting of the Sprague River. Some of this downcutting may have resulted from base-level fall associated with integration of the upper Klamath River Basin (Sherrod and Pickthorn, 1992), but some terrace sequences may represent more local tectonic blockages associated with the north-northwest trending basin-and-range faulting affecting the downstream Sprague River Valley segments or regional aggradation during periods of enhanced sediment production in the basin.

\section{Sycan Flood Deposits}

A prominent planar surface extends south discontinuously from the Sycan Canyon, encompassing $5.1 \mathrm{~km}^{2}$ of the Sycan River valley bottom and its confluence with the Sprague River. This surface stands $3 \mathrm{~m}$ higher than the active flood plain at the downstream end of Sycan Canyon and descends to modern flood-plain level near the Sycan River confluence with the Sprague River (figs. 5, $\underline{6}$ ). The surface is underlain by as much as $3.35 \mathrm{~m}$ of bedded sand and gravel composed almost entirely of Mazama pumice (fig. 7). The deposits are finer and thinner downstream, where they are overlain by alternating beds of silty fine sand and sand. At their apex near the downstream end of the Sycan Canyon, these deposits grade to surfaces mantled with 1-m-diameter rounded basalt boulders, apparently originating from the canyon rim and walls and transported downstream. The soil capping these surfaces is classified mainly as an Ashy Typic Cryopsamment, denoting poorly developed soils formed in ash-rich and sandy parent materials. The pumiceous sand and gravel overlie organic-rich silt and clay deposits, locally peaty, and commonly containing, within 3-5 cm of its top, a 0.5 -to- 2.5 -cm-thick layer of silt-and sand-size Mazama tephra (figs. 5, $\underline{8}-10$ ). This fallout tephra (fig. 10), its age constrained by radiocarbon dates here (fig. 5; appendix B) and in other areas (Hallett and others, 1997; Zdanowicz and others, 1999; Bacon and Lanphere, 2006), resulted from the Mazama eruption of about 7,700 cal yr BP. 


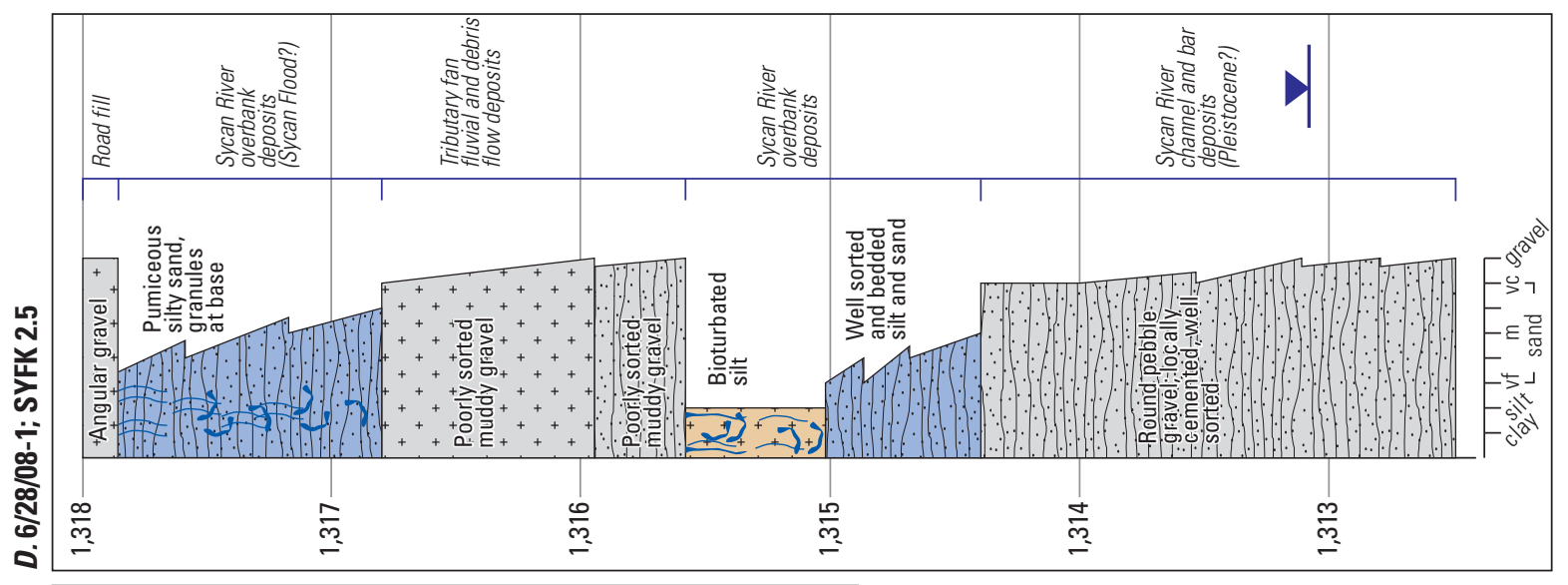

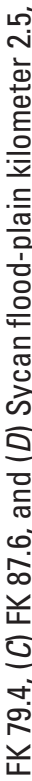
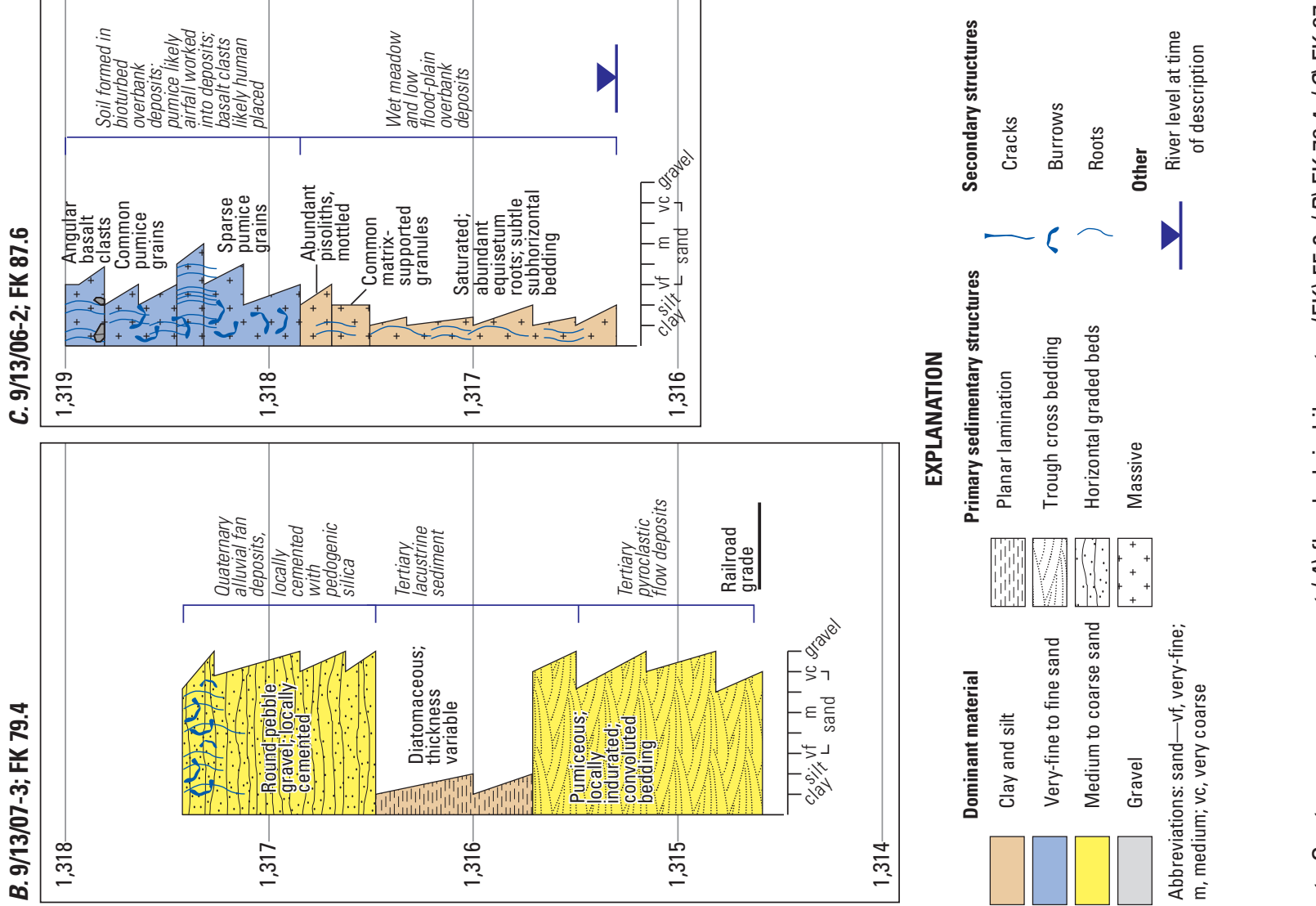

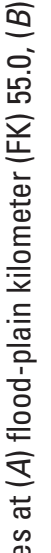
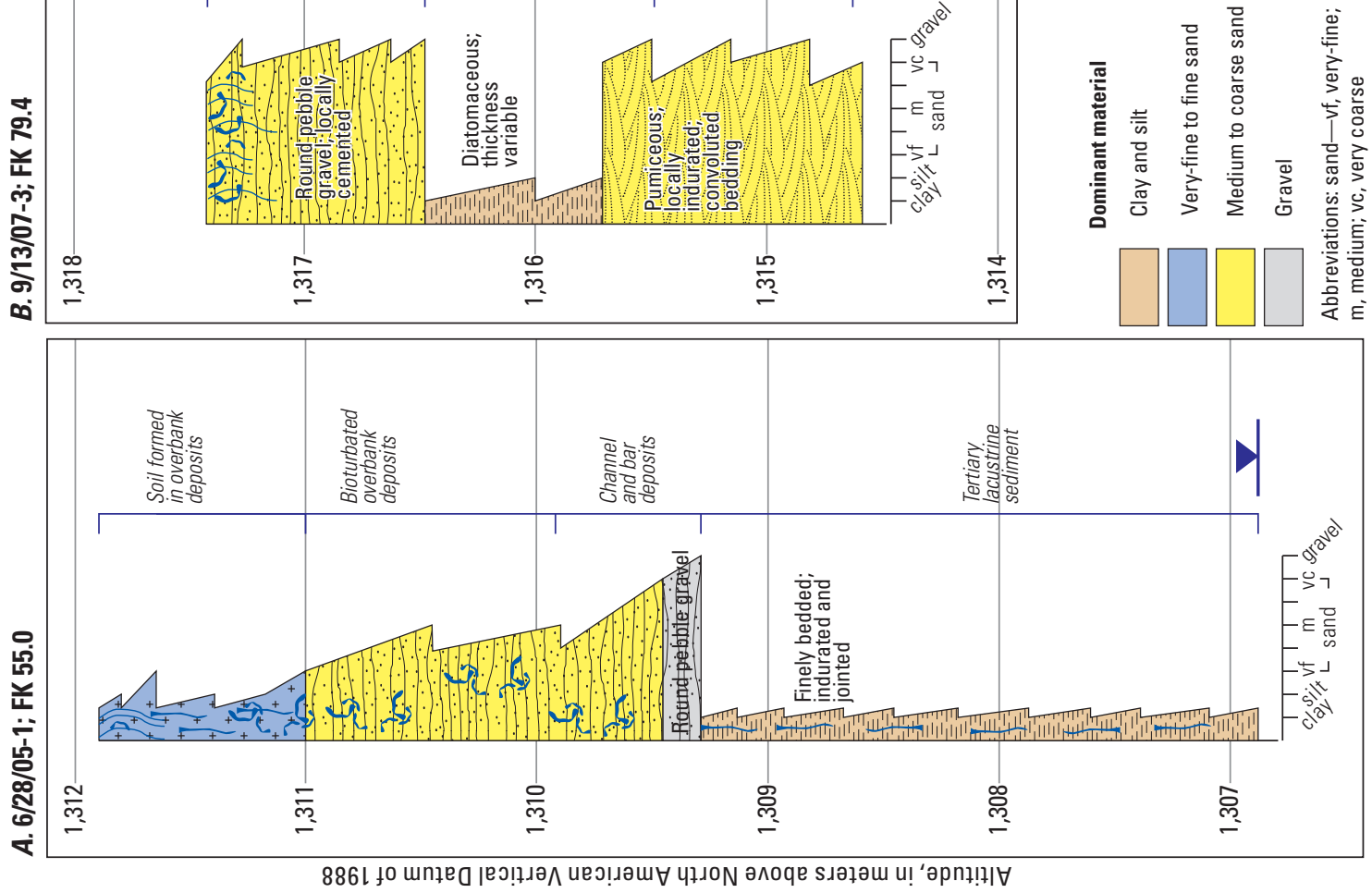

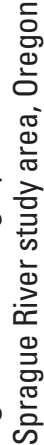


We infer that the Sycan flood deposits resulted from a large, pumice-laden flood down the Sycan River within a few decades or centuries of the 7,700 cal yr BP eruption. This flood and its origins and effects are described more fully in Lind (2009). The close proximity of the base of the deposits to unweathered Mazama fallout tephra (fig. 10) indicates deposition shortly after the eruption. The lack of stratigraphic breaks or other evidence of deposition hiatus within the thick pumiceous sand indicates deposition during a single event. The sedimentary structures (general upward fining of sediment textures in individual sections, as well the downstream fining and flat planar surface) also indicate fluvial deposition during a single event. Toward the Sycan River confluence with the Sprague River, where the flood deposits are closest to river level, the sedimentary structures are overlain by bedded silt and sand deposited by subsequent floods.

Although no mappable Sycan flood deposits are evident downstream of the Sycan River confluence with the Sprague River, the sediment-laden flow almost certainly continued downstream, probably with substantial effects to channel plan form and geometry. A 1948 excavation at Medicine Rock Cave, flanking the Sprague River near FK 11.0 between Braymill and Chiloquin, revealed as much as $50 \mathrm{~cm}$ of fluvially transported pumiceous sand and silt attributable to a short-lived episode of deposition shortly after the Mazama eruption (Cressman and others, 1956, p. 398-400). This distinct deposit, interbedded within a sequence of Sprague River fluvial deposits, rock from roof-fall, and occupation detritus, almost certainly is from the Sycan flood, and is evidence that the flow was one of the largest late Holocene floods on the main-stem Sprague River.

A plausible source for such a flood was the temporary impoundment of a lake in the Sycan Marsh area, possibly by dunes of Mazama pumice blocking the Sycan River channel near the marsh outlet (Lind, 2009). The Sycan flood probably had a mechanism, timing, and perhaps magnitude similar to that of a flood descending the Williamson River from Klamath Marsh after breach of a Mazama pyroclastic flow deposit that blocked the marsh outlet (Conaway, 2000; Cummings and Conaway, 2009).

The Sycan flood deposits are coarse, loose, and erode readily from disturbed sites, particularly along tall banks flanking the modern channel or flood plain (fig. 7). In eroding areas, the Sycan flood deposits provide substantial sand-size material to the lower Sycan River.
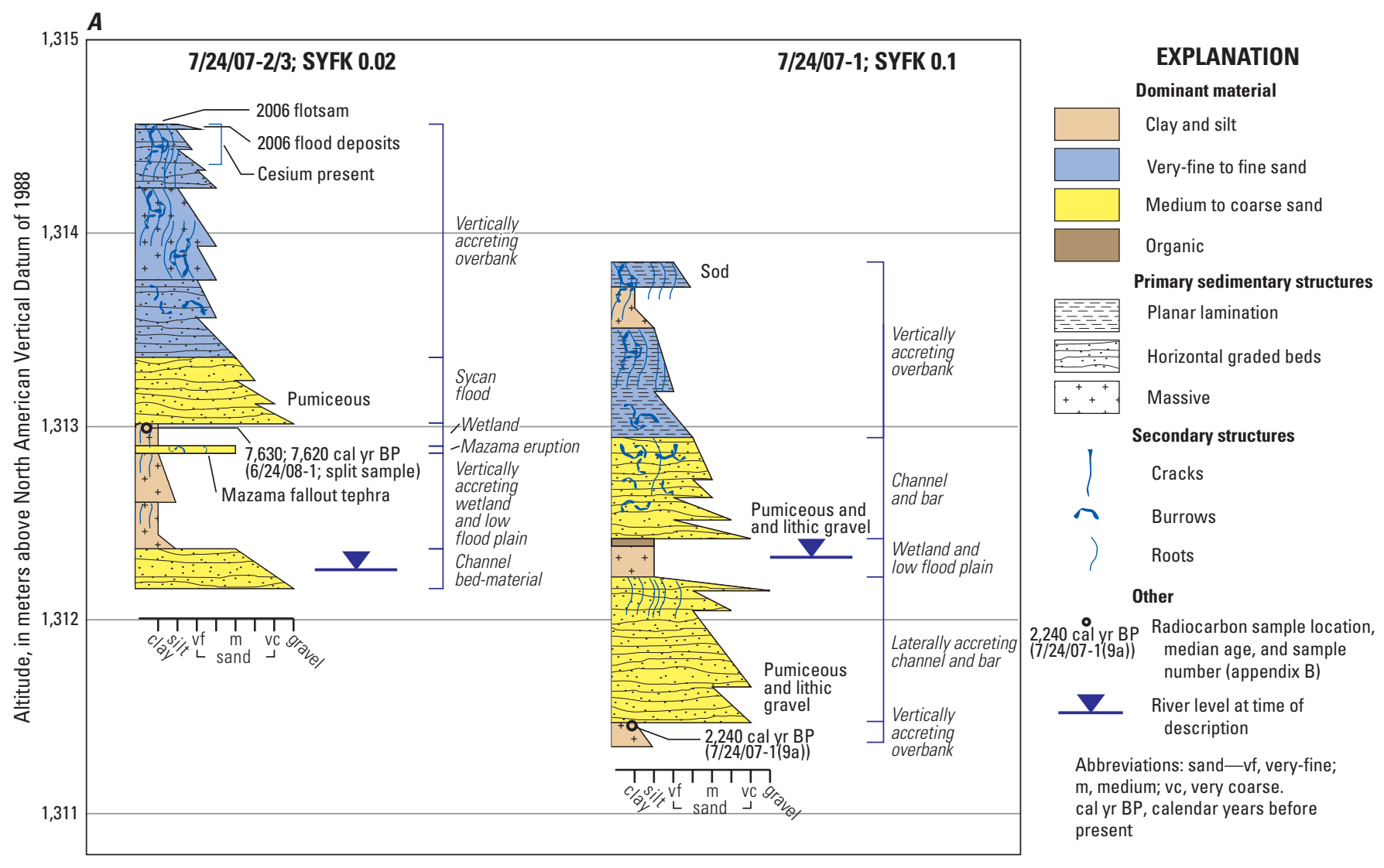

Figure 5. Stratigraphic sections of $(A)$ Sycan River flood-plain kilometers (SYFK) 0.02 and $0.1 ;(B)$ SYFK 1.6 and $1.7 ;(C)$ SYFK $3.5 ;(D)$ SYFK 6.8 and 7.3 ; and $(E)$ SYFK 10.1, 10.3, and 10.6, Sprague River study area, Oregon. 


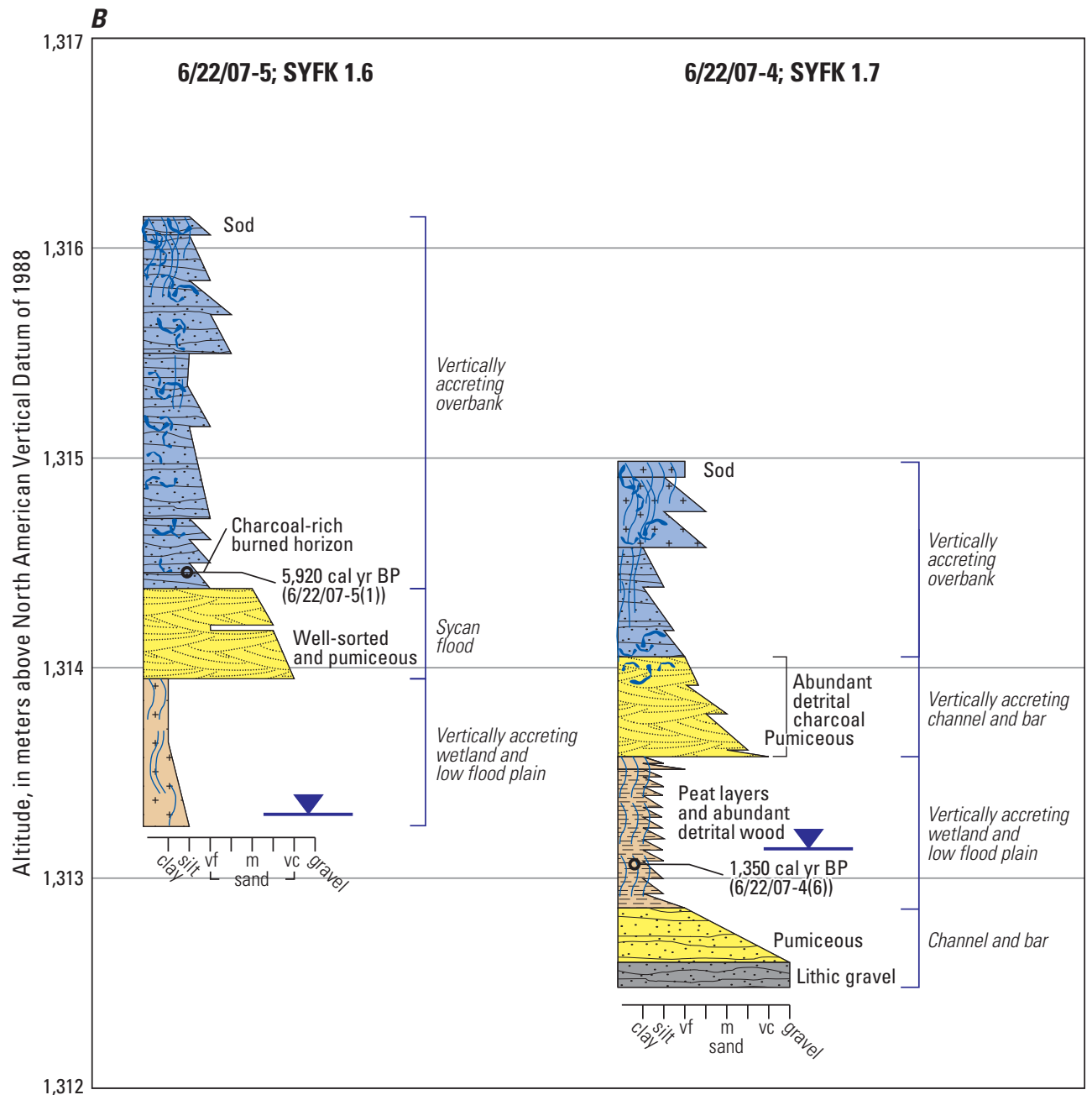

EXPLANATION

Dominant material

Clay and silt

Very-fine to fine sand

Medium to coarse sand

Primary sedimentary structures

Planar lamination

- Trough cross bedding

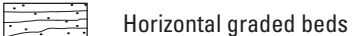

${ }_{++}^{+}+$Massive

Secondary structures

Cracks

Burrows

Roots

Other

1,350 cal yr BP Radiocarbon sample location, $(6 / 22 / 07-4(6)) \quad$ median age, and sample number (appendix B)

$\boldsymbol{\nabla}$ River level at time of description

Abbreviations: sand-vf, very-fine; $\mathrm{m}$, medium; vc, very coarse. cal yr BP, calendar years before present

Figure 5.-Continued 

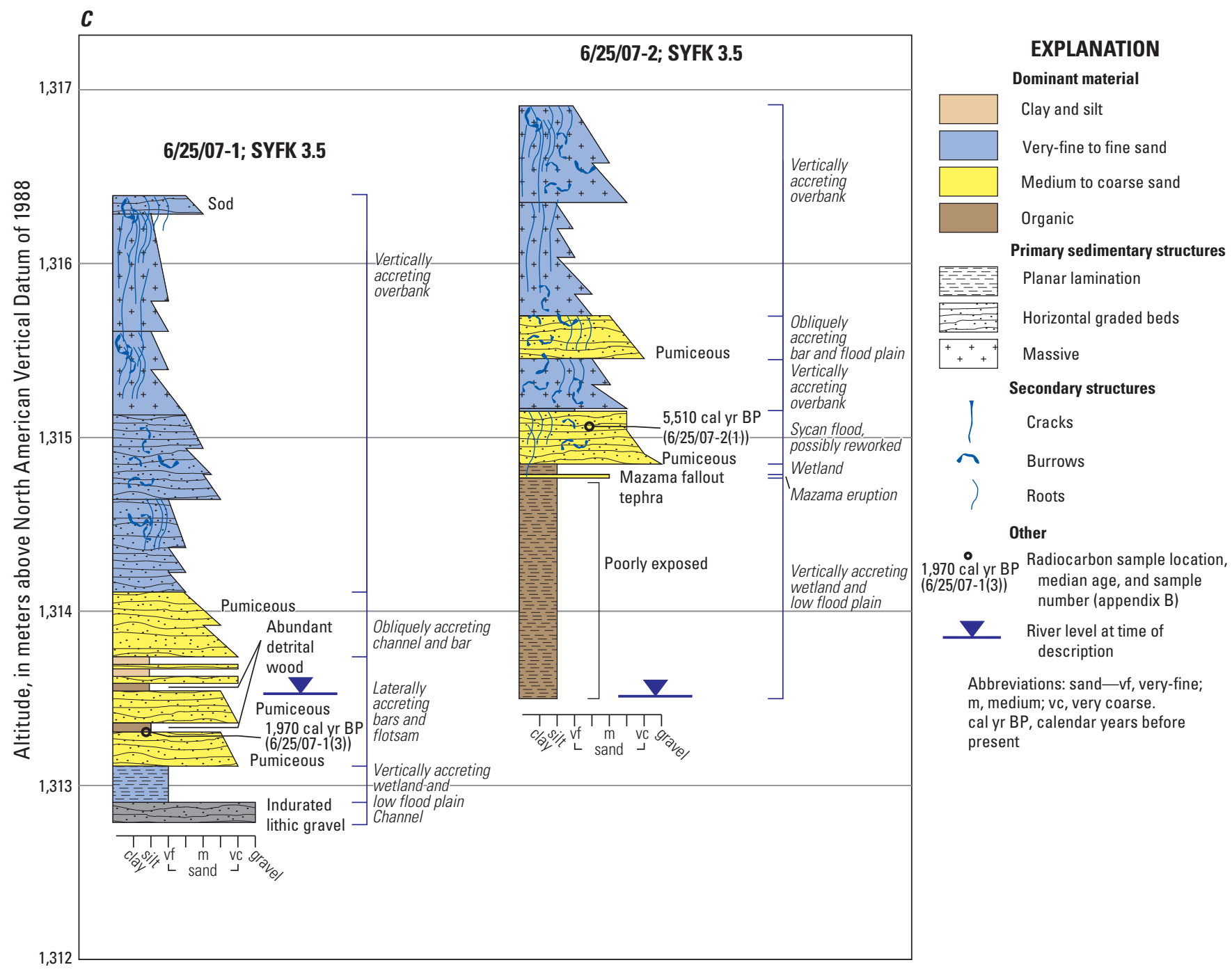

Abbreviations: sand-vf, very-fine; $\mathrm{m}$, medium; vc, very coarse. cal yr BP, calendar years before present

Figure 5.-Continued 

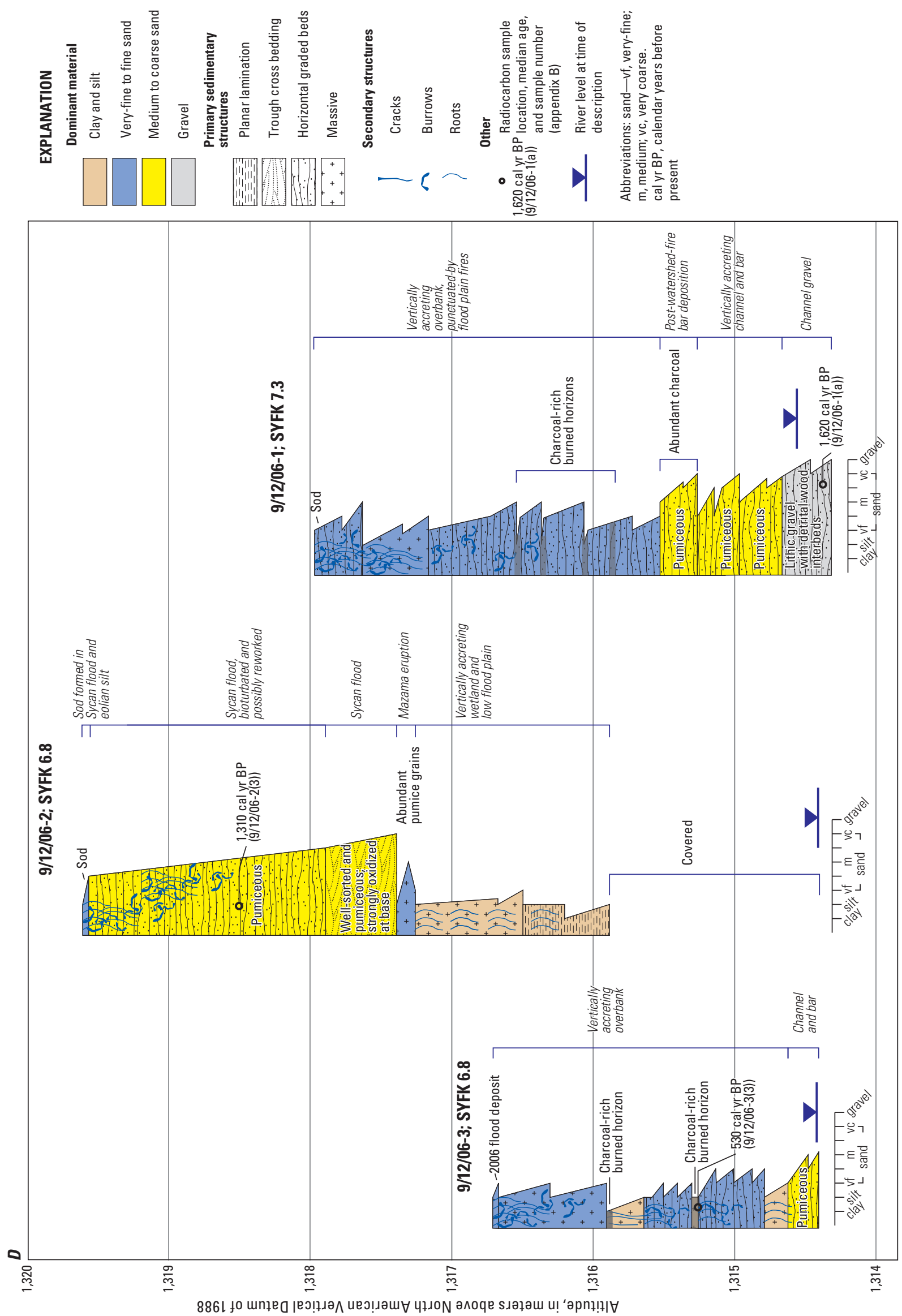

ర) 


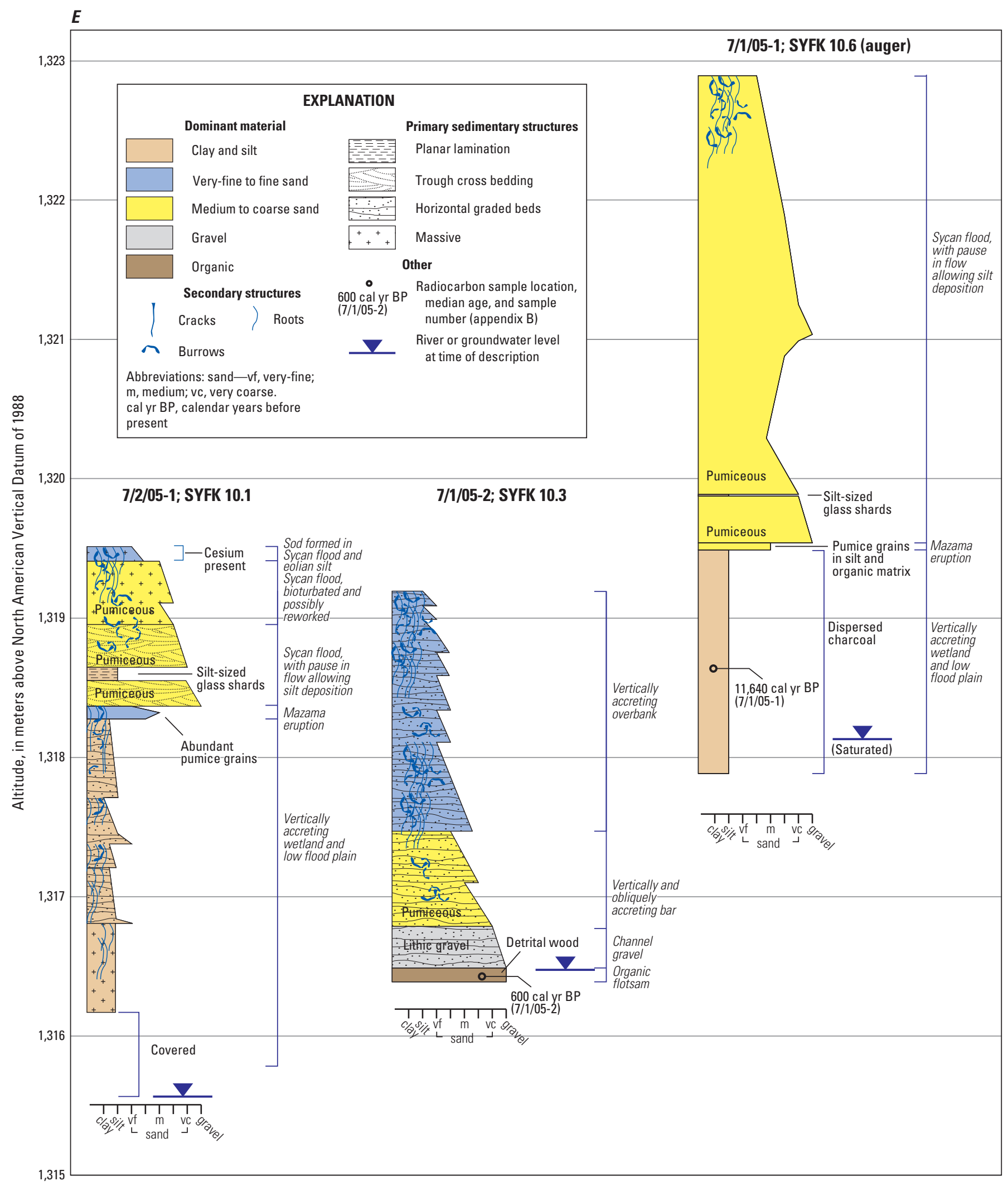

Figure 5.-Continued 


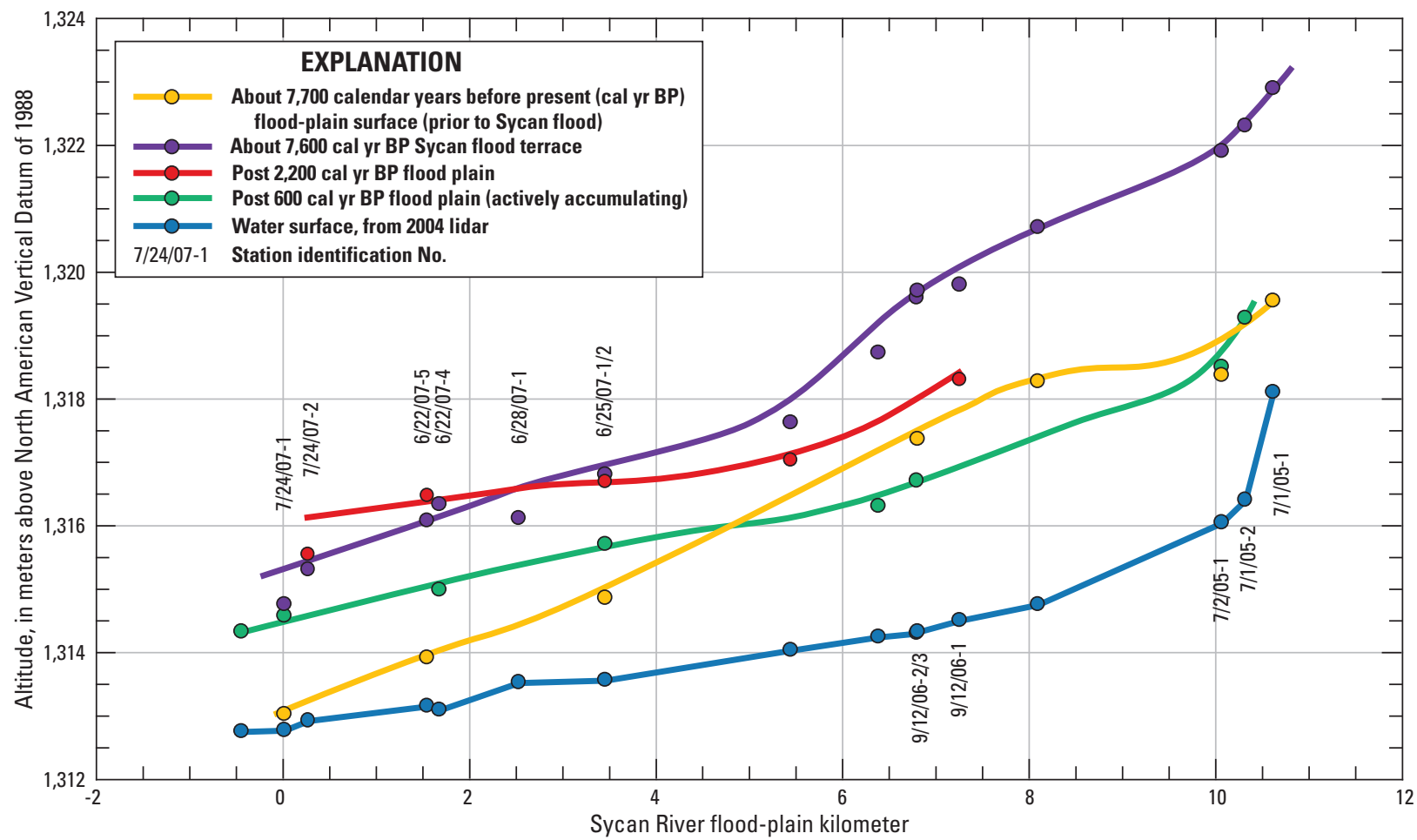

Figure 6. Flood-plain and terrace surface profiles estimated from stratigraphic sections and observations along lower Sycan River, Sprague River study area, Oregon. Modified from Lind (2009).
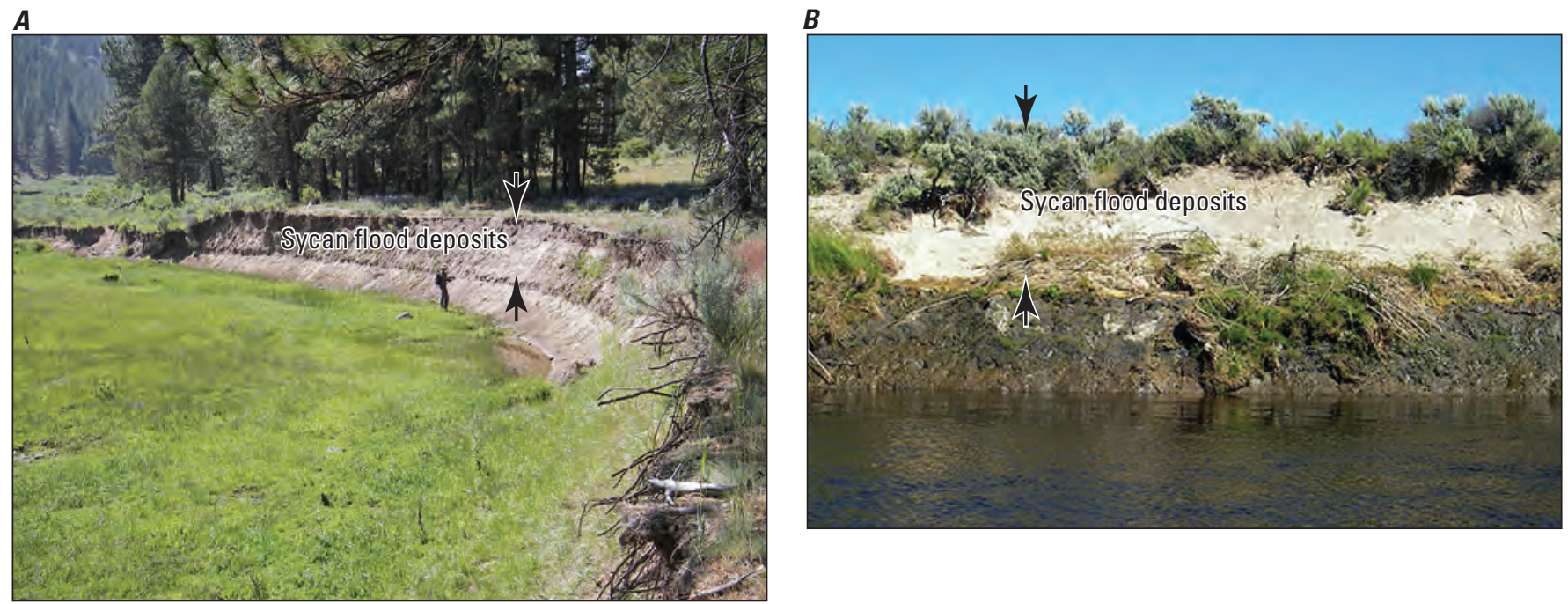

Figure 7. Pumiceous sand deposits of the Sycan flood about 7,700 calendar years before present at $(A)$ exposed site $7 / 2 / 05-1$, Sycan River flood-plain kilometer (SYFK) 10.1 (July 2, 2005); and (B) site 9/12/06-2, SYFK 6.1 (June 20, 2006), lower Sycan River valley segment, Sprague River study area, Oregon. Photographs taken by J.E. O'Connor, U.S. Geological Survey. 


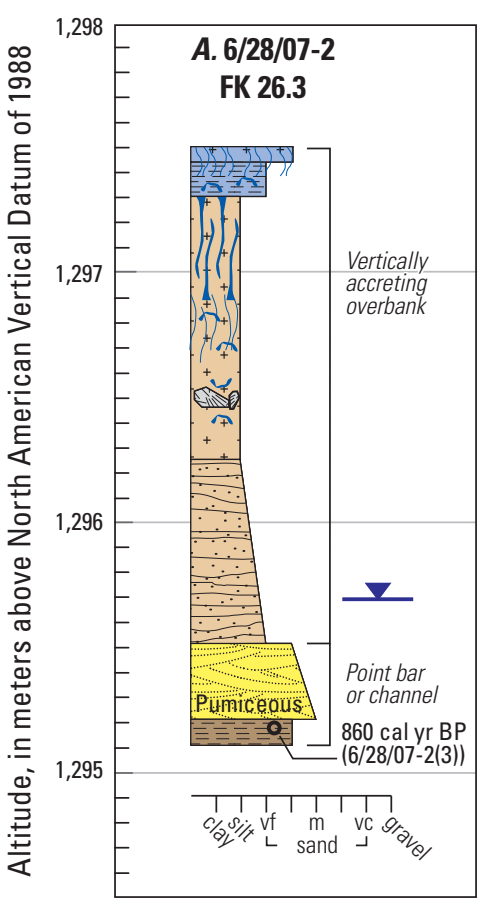

\section{EXPLANATION}

Dominant material

\begin{tabular}{|l|l}
\hline & Clay and silt \\
\hline & Very-fine to fine sand \\
\hline & Medium to coarse sand \\
\hline & Gravel \\
\hline & Organic
\end{tabular}

Primary sedimentary structures

Trough cross bedding
Horizontal graded beds

Secondary structures

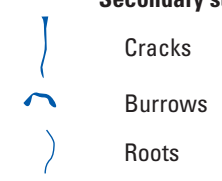

Other

Outsized rock clasts

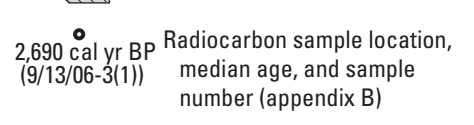

$\checkmark$ River level at time of description

Abbreviations: sand-vf, very-fine;

$\mathrm{m}$, medium; vc, very coarse.

cal yr BP, calendar years before

present

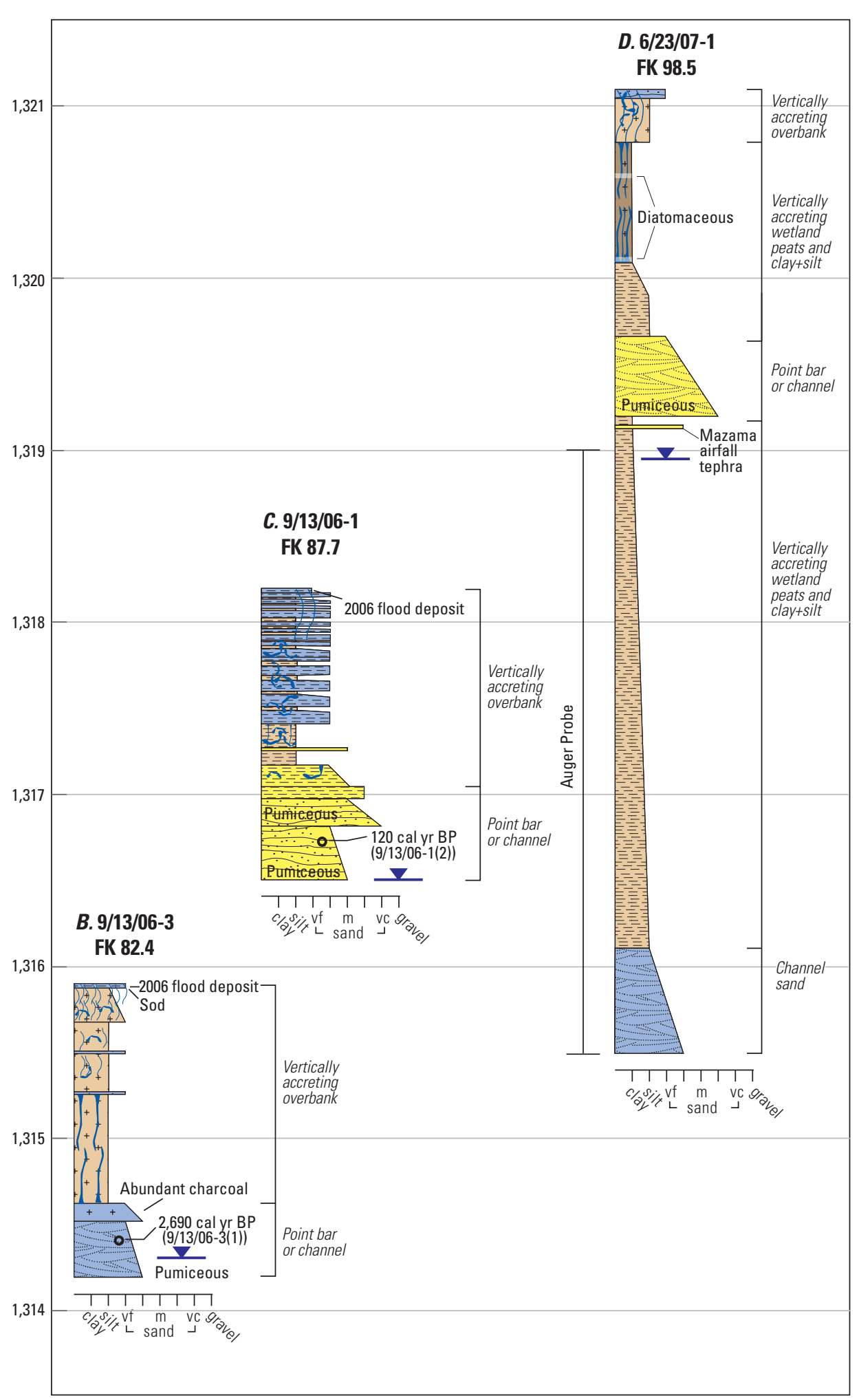

Figure 8. Stratigraphic sections of $(A)$ flood-plain kilometer (FK) 26.3, (B) FK 82.4, (C) FK 87.7, and (D) FK 98.5, along main-stem and South Fork Sprague River geomorphic flood plain, Oregon. 


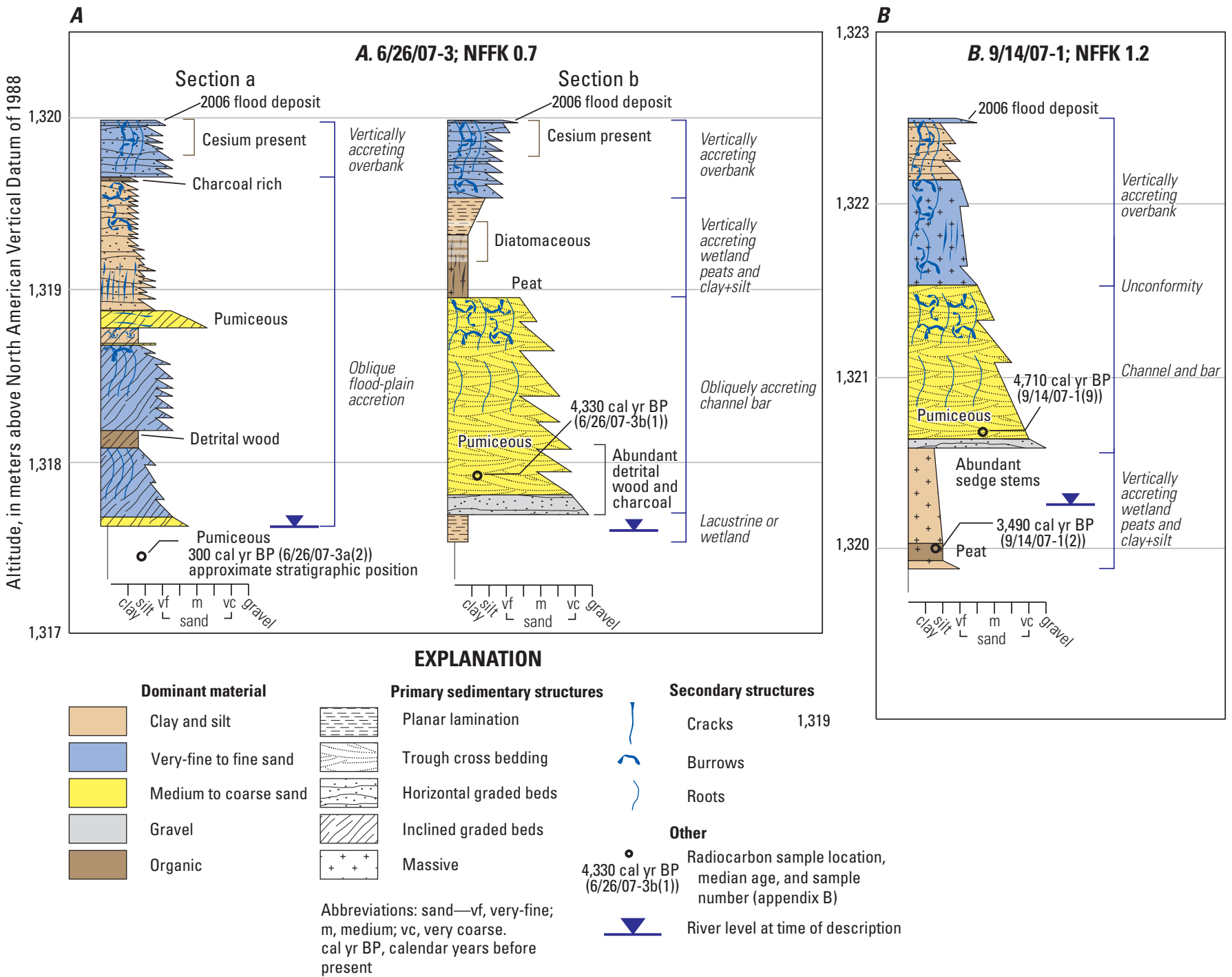

Figure 9. Stratigraphic sections of $(A)$ North Fork Sprague River flood-plain kilometer (NFFK) 0.7, and (B) NFFK 1.2, along North Fork Sprague River geomorphic flood plain, Oregon. 


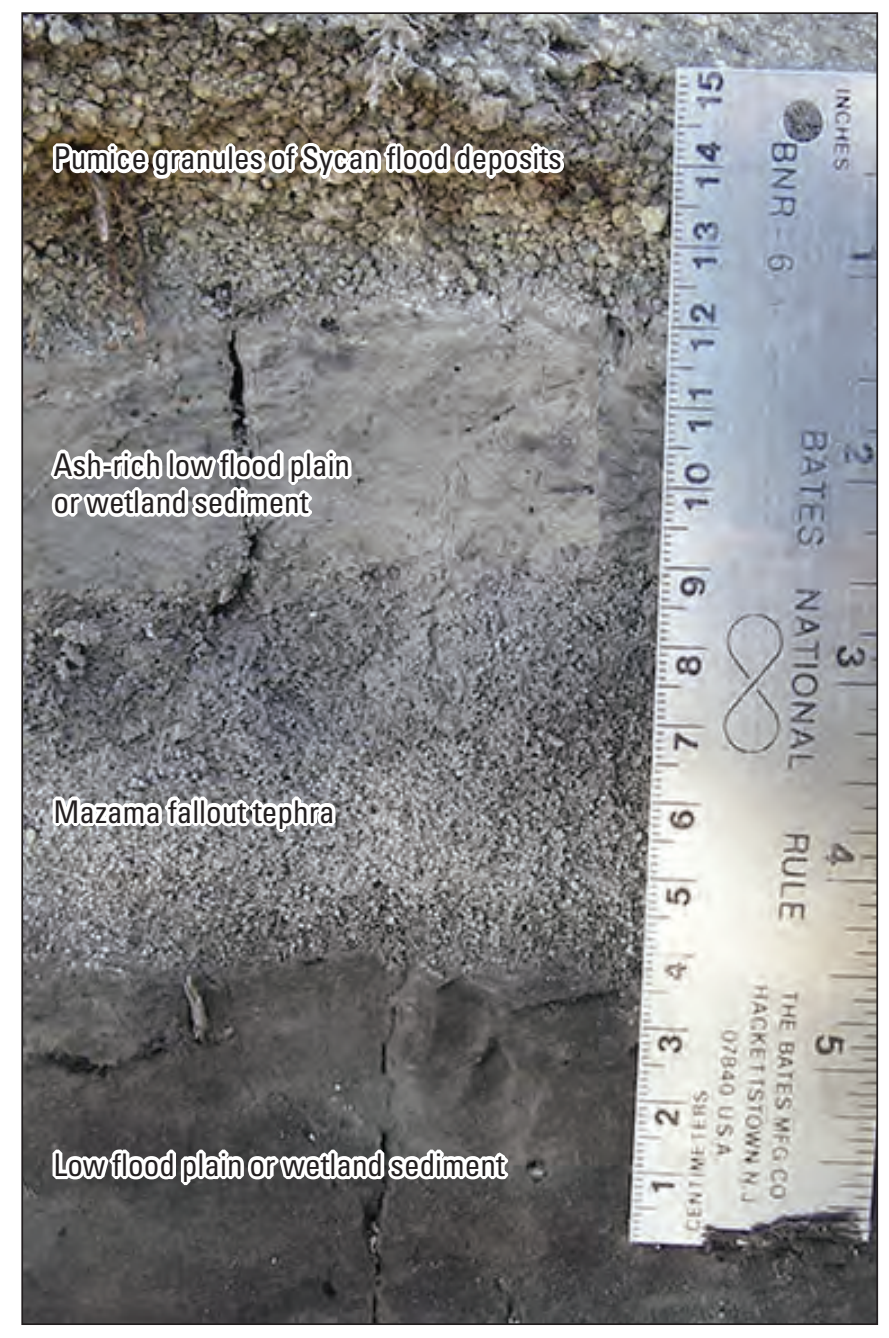

Figure 10. Mazama fallout tephra and Sycan flood deposits exposed at site 7/24/07-2/3, Sycan River flood-plain kilometer (SYFK) 0.02, Sprague River study area, Oregon. Photograph taken by J.E. O'Connor, U.S. Geological Survey, September 12, 2007.

\section{Active Tributary Flood Plain}

Tributary channels and flanking surfaces grade to modern main-stem channels and flood plains, forming narrow and elongate surfaces extending into the uplands where channels become increasingly confined. In some areas, especially near Kamkaun Spring, the tributary valleys have very low, nearly horizontal gradients, whereas in many locations, tributary valley flood plains have gradients of as much as 5 degrees. The distinction between tributary fans and colluvium locally is indistinct, but primarily is made on the basis of plan-view morphology and slope. Primary soils on tributary flood plains are Inceptisols and Mollisols, which typically form in late Pleistocene or Holocene deposits (U.S. Department of Agriculture, 1975).

\section{Main-Stem Valley Fill}

Low-gradient planar surfaces totaling $28 \mathrm{~km}^{2}$ occupy broad basins flanking the main Sprague River flood plain, particularly downstream of the town of Sprague River. Additionally, this map unit includes narrow bottomlands flanking the post-Mazama zone of channel migration (the geomorphic flood plain) between Sprague River and Beatty Gap. These surfaces generally have soils mapped as Inceptisols or Mollisols formed partly by cumulic deposition of silt and clay during overbank flooding. Many of the surfaces were historically flooded during periods of high water, but showed no evidence of hosting major channels. Many of the surfaces now are diked and drained. Some of the broad valley bottoms marginal to the main river course appear to be sites of long-term sediment accumulation as a consequence of overall Sprague River Valley aggradation, perhaps in conjunction with block faulting along the northnorthwest trending faults transecting the lower part of the Sprague River Valley. In places, this map unit may correspond with low terraces mapped upstream of the town of Sprague River. The valley-fill map unit represents areas of Holocene deposition during main-stem overbank flooding as well as from local runoff during seasonal high water.

\section{Pond and Wetland Deposits}

Several small closed depressions host seasonal-toperennial waterbodies. In plate 1, these waterbodies are distinguished only outside the geomorphic flood plains, although all waterbodies are mapped for each aerial photographic set. Most of these waterbodies shown on plate 1 are within areas of valley fill or occupy depressions within abandoned alluvial fans. Nearly all waterbodies are used for water storage, with dikes or small dams augmenting storage capacity.

\section{Active Springs and Spring Deposits}

Springs and related features such as ponds, wetlands, and channels are common within the study area. Most of these features are within or contiguous with the geomorphic flood plain or flanking terraces. Spring outlets with flowing water have sandy-to-gravel substrates, whereas surrounding saturated areas are composed mainly of peat deposits. Most spring complexes are connected to the Sprague and Sycan Rivers by sand-bed spring channels.

\section{Geomorphic Flood Plain}

The channels and active flood plains (encompassing $78 \mathrm{~km}^{2}$ along the North Fork Sprague, South Fork Sprague, main-stem Sprague, and Sycan Rivers) are included in a single map unit identified as the Geomorphic Flood Plain. 
This map unit is the domain of the detailed mapping analysis of constructed features, historical channel change, and vegetation. It encompasses the area of channels, abandoned channels, and scroll-bar topography evident from the 2004 lidar data. The presence of topographic features indicative of channelized flow distinguishes the Geomorphic Flood Plain from the Valley Fill unit. Soils typically are poorly drained and volcanic-ash-rich Mollisols dominated by the Klamath-OntkoDilman series (Cahoon, 1985). Stratigraphy exposed on eroding streambanks and from augering (figs. 5, $\underline{8}, \underline{9}, \underline{11}-\underline{14}$ ) show that these flood-plain deposits almost everywhere formed after the 7,700 cal yr BP Mazama eruption. In places, particularly along the lower Sycan River (Lind, 2009) and the North Fork Sprague River, stratigraphic relations show two or three episodes of flood-plain erosion and rebuilding over the last 6,000 years (igs. $5, \underline{6}, \underline{9}, \underline{11}, \underline{14}$ ). As described in more detail in subsequent sections, the geomorphic flood plain has formed in the last 7,700 years from a combination of channel migration, channel avulsion, and lateral and vertical accretion of bedload and suspended-load deposits. The geomorphic flood plain is mapped on the basis of morphology, soils, and stratigraphy, and does not necessarily correspond to a specific height above the channel or areas subject to flooding at a specific frequency.

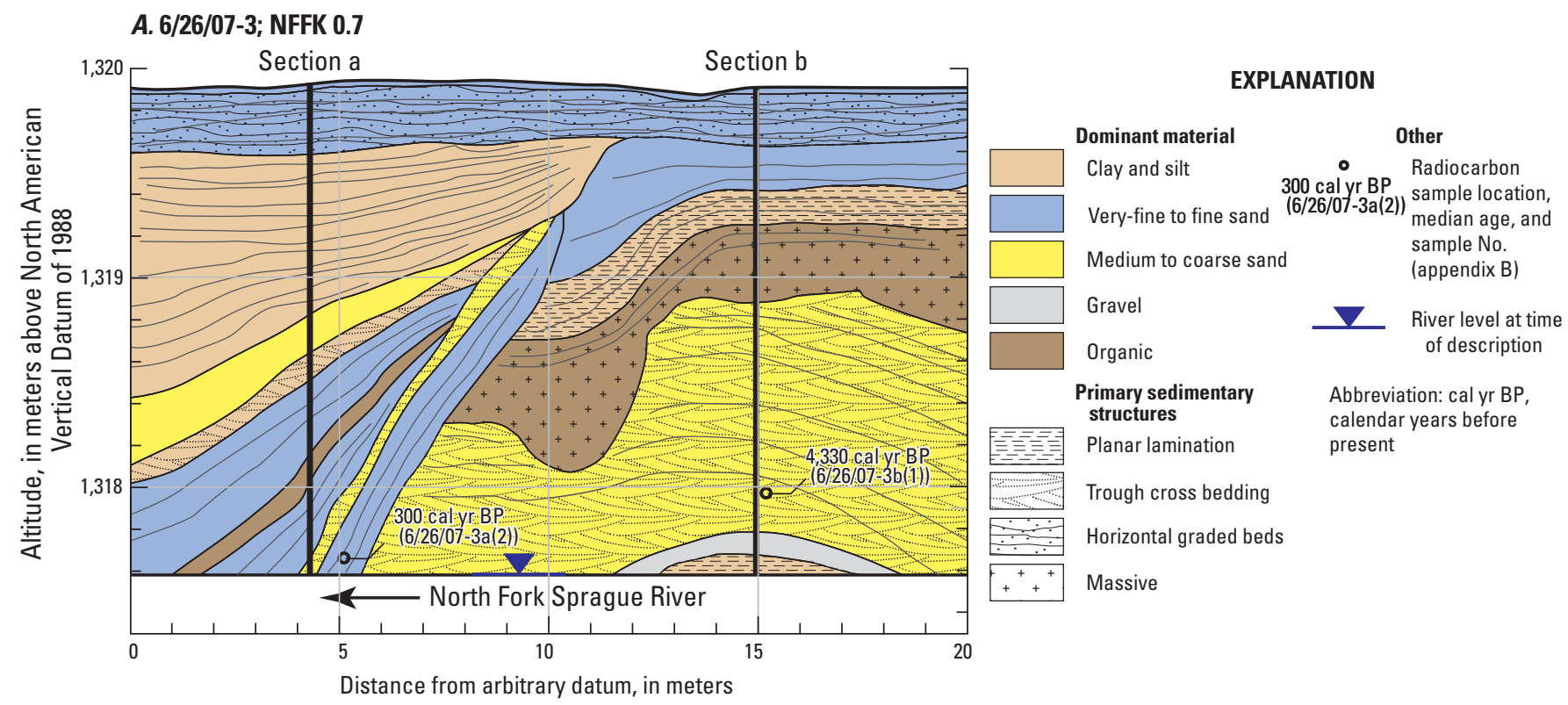

B. NFFK 0.9

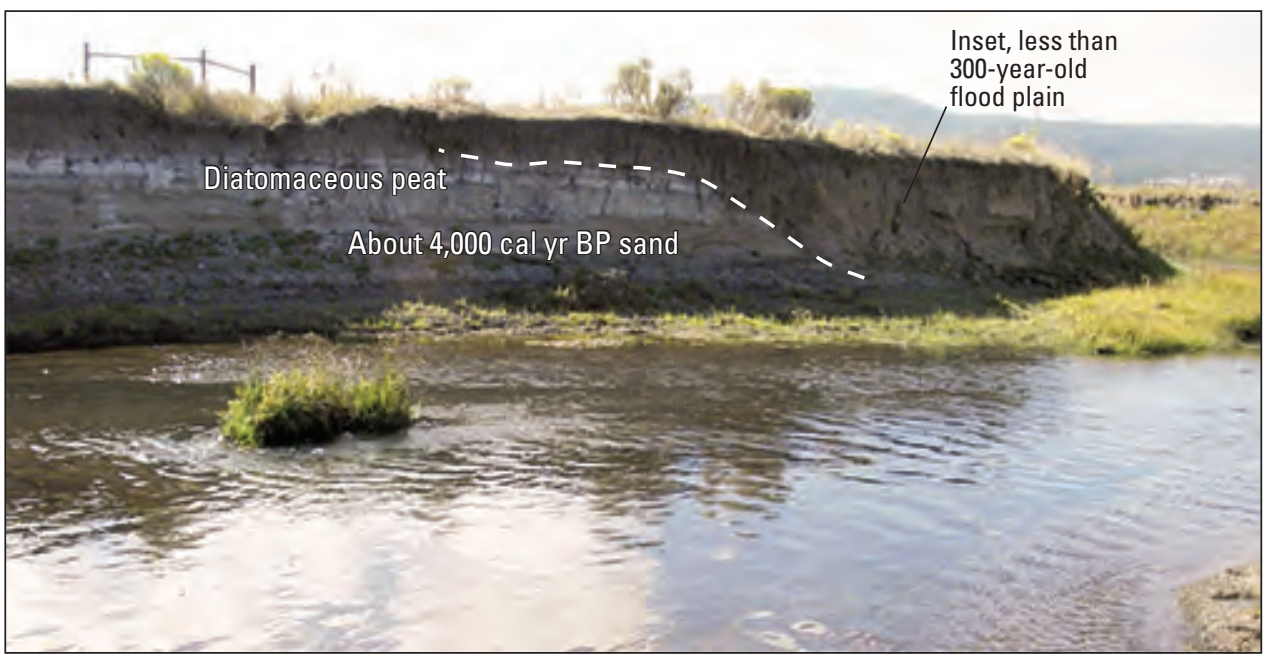

Figure 11. Late Holocene inset flood-plain deposits at the $(A)$ right-bank exposure at North Fork Sprague River flood-plain kilometer (NFFK) 0.7, and (B) left-bank exposure at NFFK 0.9, along North Fork Sprague River, Oregon. Photograph taken by J.E. O'Connor, U.S. Geological Survey, September 14, 2007. 


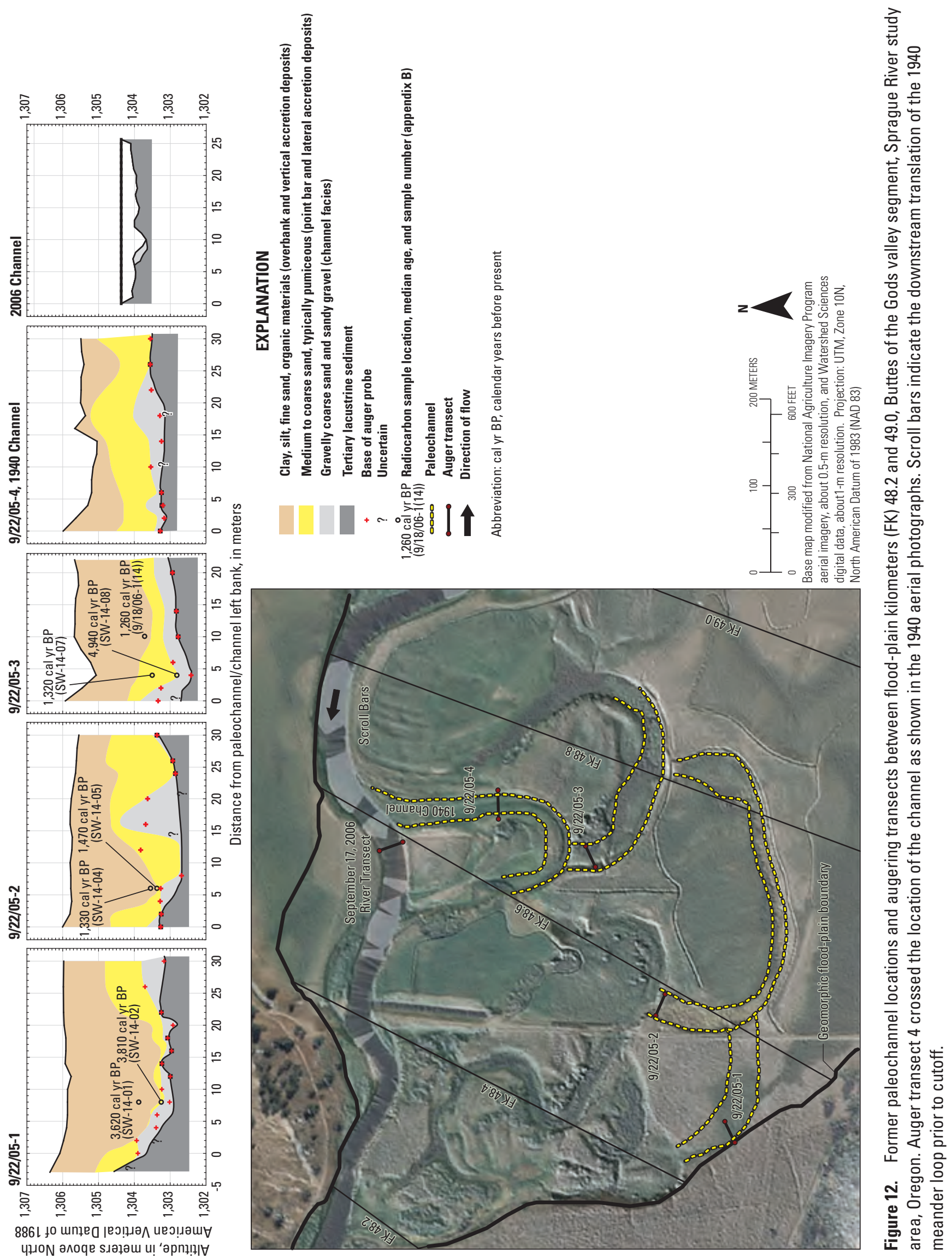




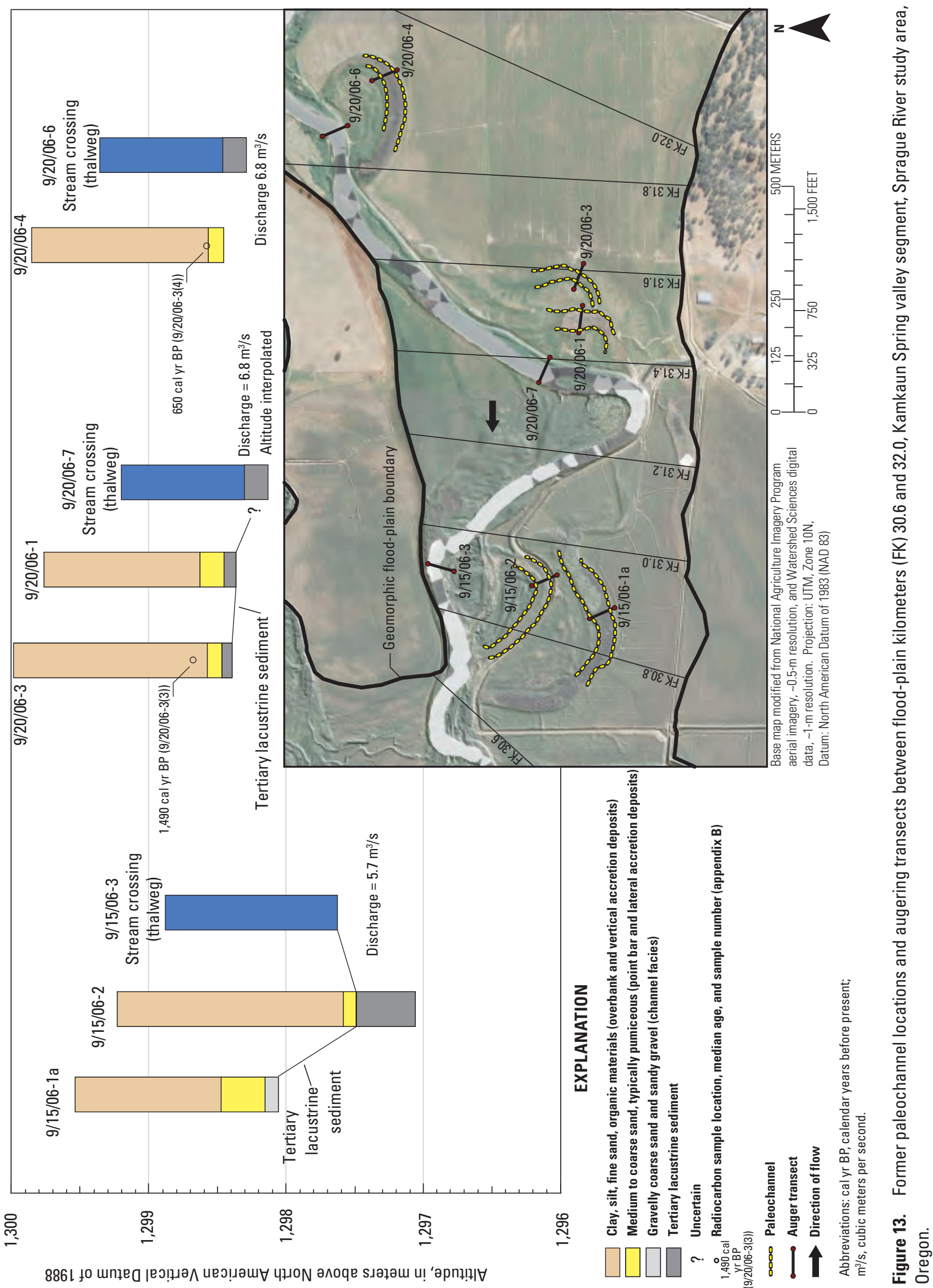




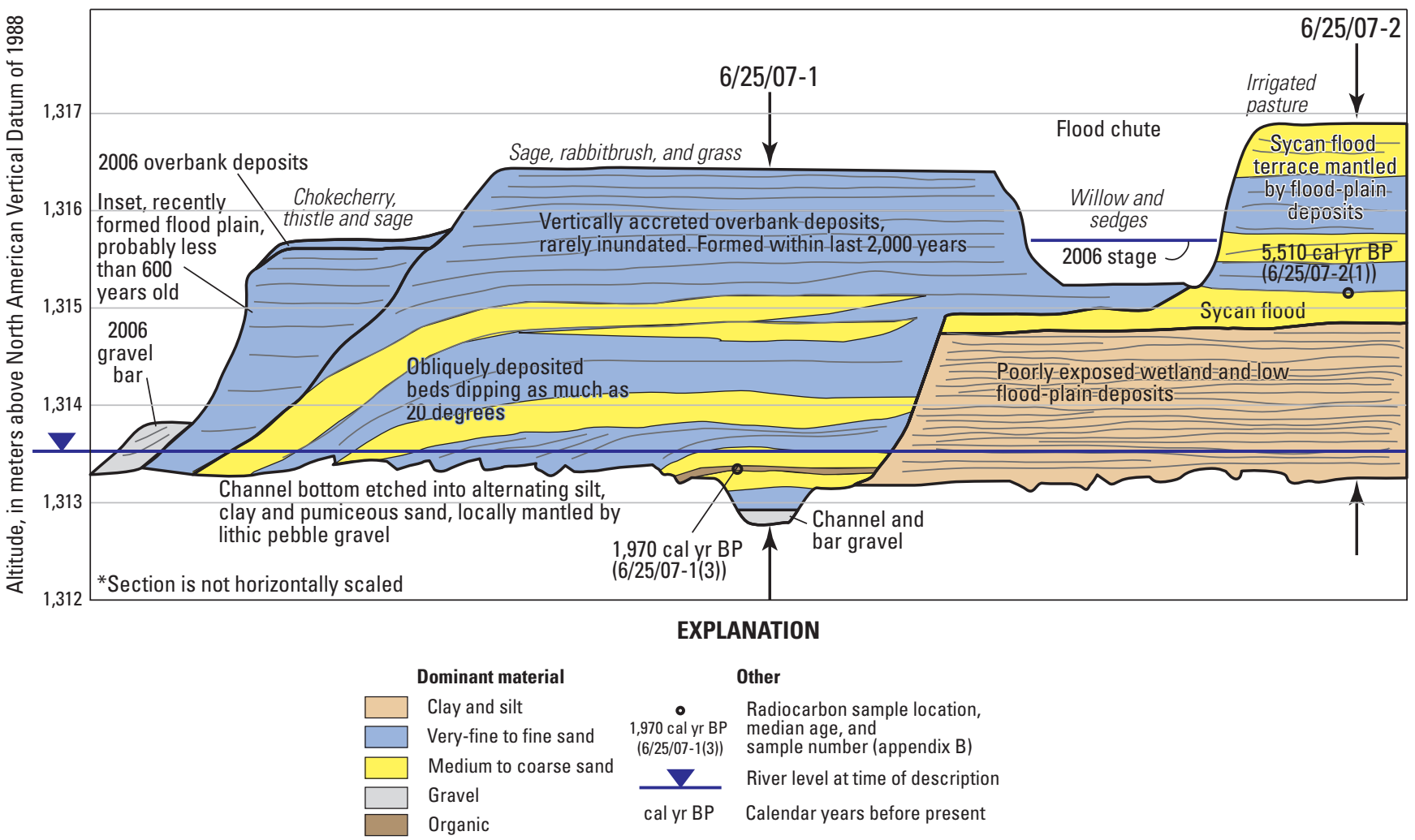

Figure 14. Stratigraphic relation among flood-plain and terrace deposits in Lower Sycan valley segment, Sycan River flood-plain kilometer 3.5, Sprague River study area, Oregon. Stratigraphy represents exposure along approximately 300 meters of right channel margin; horizontal axis is not to scale. Sections 6/25/07-1 and 6/25/07-2 are shown in more detail in figure 5.

\section{Synopsis of Quaternary Geologic History and Sprague River Geomorphology}

This mapping and previous geologic studies support general inferences regarding the Quaternary geologic history of processes and events that have shaped the Sprague River and its major tributaries. During the Miocene and Pliocene, river networks developing in this area periodically were blocked by lava flows and faulting, creating a landscape of lakes and rivers. The present Sprague River downstream of Beatty Gap developed after the 3.0 0.9 Ma eruption of the Basalt of Knot Tableland. Since then, widespread lacustrine sedimentation ended and the Sprague River became integrated into the Klamath River drainage. This integration caused the Sprague River and its major tributaries to incise, locally leaving terraces and abandoned and incised alluvial fans (Sherrod and Pickthorn, 1992). This regional incision probably has not been temporally continuous or spatially even, but interrupted by changes in sediment influx and transport capacity owing to changes in climate, hillslope sediment production, and volcanic sediment influxes. This regional incision also has been interrupted by local uplift and subsidence associated with block faulting along north-northwest to north-northeast trending faults transecting the Sprague River course.
Quaternary faulting probably has been a major factor affecting the lower $60 \mathrm{~km}$ of Sprague River channel, which winds across the trends of several fault zones mapped by Sherrod and Pickthorn (1992). The prominent steepening of the Sprague River at FK 11.4 may owe to uplift and westward tilting along two up-to-the-west north-trending normal faults at FKs 13.0 and 14.5 in conjunction with subsidence to the west of the graben containing Upper Klamath Lake. Tectonic blockage associated with these structures between FKs 13.0 and 14.5 also is consistent with the expansive valley fill deposits near Kamkaun Spring and upstream.

Although there is no absolute age information on the lowest terraces and abandoned alluvial fans flanking the main-stem rivers, their slightly elevated surfaces of as much as $2 \mathrm{~m}$ higher than the main-stem geomorphic flood plain, gravel composition, and capping soils indicate an episode of late Pleistocene valley aggradation. Such aggradation would be consistent with that found for many valleys in the Western United States during and after the last glacial episode of 20-30 thousand years ago, such as the Willamette Valley of western Oregon (O'Connor and others, 2001).

Subsequent to the formation of these terrace surfaces, probably during the late Pleistocene, the Sprague River and its major tributaries incised as much as $2 \mathrm{~m}$ (figs. $4, \underline{8}$, 9) in conjunction with forming Holocene flood plains and 
valley fill. The broad distribution of valley-fill deposits, the locally wide geomorphic flood plain, and the wide tributary flood plains and fans, however, are all evidence of little or no net river incision during the Holocene. The position of the 7,700 cal yr BP Mazama tephra in bank exposures and auger holes indicates little widespread incision since the eruption, although local reaches of the lower Sycan River and North Fork Sprague River have had flood-plain erosion and deposition episodes over the last 6,000 years (figs. 5, 9, 11-14).

The 7,700 cal yr BP Mazama eruption greatly affected the Sprague River fluvial system. Besides many indirect effects on basin hydrology and vegetation from as much as $1 \mathrm{~m}$ of tephra deposition, the large input of sand-size tephra to the basin substantially affected flood-plain and channel processes and their morphology. The watershed of the Sycan River was affected most, being closest to Mount Mazama and accumulating the thickest tephra fall. The Sycan flood deposited as much as $3.3 \mathrm{~m}$ of pumiceous sand during a single flood within a few decades or centuries after the eruption, forming a broad fan originally encompassing an area of about $17 \mathrm{~km}^{2}$ with a total sediment volume of 14 million $\mathrm{m}^{3}$ (Lind, 2009). The Sycan River has incised into the Sycan flood deposits (pl. 1) and reestablished a flood plain (figs. 6 and 14), but the sandy deposits remains a source of sand-size sediment for the Sycan and Sprague Rivers (fig. 7). The large volumes of sand-size sediment in the Sycan River transformed the river from one with fine-grained cohesive banks and flood plains, presumably narrow with slow migration rates, before the
Mazama eruption (fig. 5), to a more dynamic channel after the eruption, laterally migrating in conjunction with formation of pumice-rich sandy point bars. Ensuing episodes of flood-plain erosion and deposition resulted from changes in local and basin-wide sediment supply (Lind, 2009).

The North Fork and South Fork Sprague Rivers also were affected by the Mazama fallout tephra. Stratigraphic exposures on both forks (figs. 8 and 9 ) show evidence of organicrich wetland soils capped by pumice-rich, cross-bedded sands, which indicates a transformation of wet meadows to dynamic sand-bed channels. The stratigraphic exposure along the South Fork Sprague River at FK 98.5 (fig. 8) shows subsequent transformation back to a wetland environment before 20th-century diking and incision. The exposures along the North Fork Sprague River (ig. 9) also show substantial pumiceous sand deposition in point bars followed by transformation to a low-energy wetland environment and production of peaty wetland soils.

No exposures along the main-stem Sprague River show the character of the channel and flood plain immediately prior to the Mazama eruption. Nevertheless, flood-plain morphology as well as augering and exposures of late Holocene stratigraphy (iggs. 8, 12, $\underline{13}$ ), indicates episodes of pumiceous-sand point bar formation associated with lateral channel migration and a post-Mazama flood plain much sandier than the muddy overbank deposits exposed on low Pleistocene terrace deposits (fig. 4). Active point bar deposits along the main-stem Sprague River remain largely composed of Mazama pumice grains (fig. 15).

$\boldsymbol{A}$

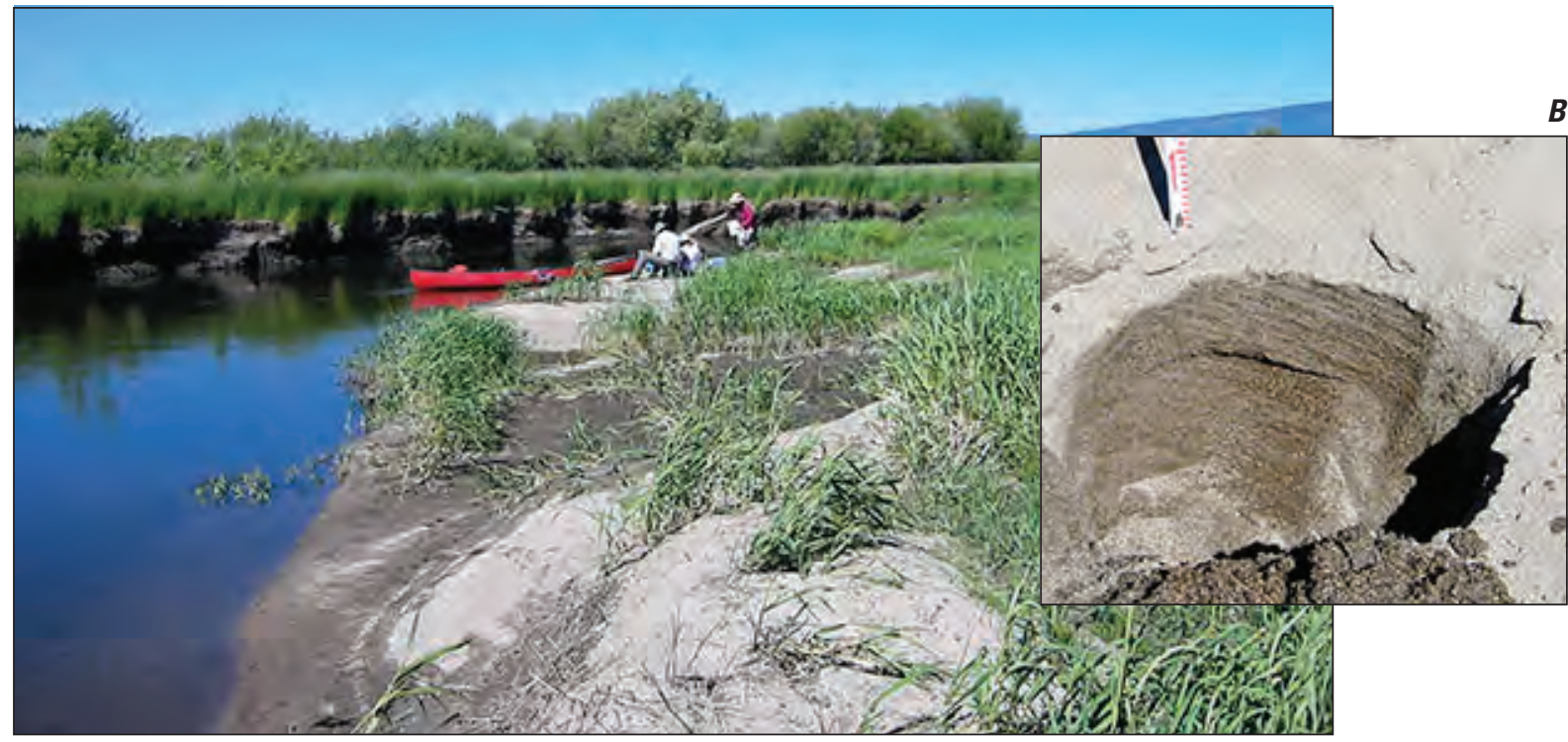

Figure 15. Point bar deposits at survey site 6/23/06-5 with $(A)$ view downstream of partly vegetated point bar mantled with coarse sand deposited during 2006 high flows, and $(B)$ 30-centimeter-deep excavation into 2006 high flow deposits showing bedded coarse sand composed mainly of pumice grains, Upper Valley segment, Sprague River study area, Oregon. Photographs taken by J.E. O'Connor, U.S. Geological Survey, June 23, 2006. Descriptions of survey sites are provided in appendix G. 
Since the major influx of Mazama tephra following the 7,700 cal yr BP eruption and before historical cultural modifications to the channels and flood plains, the Sprague River and the major tributaries probably were slowly reverting to pre-eruption sediment transport and flood-plain building conditions, although the large volume of Mazama tephra still contributes to abundant sand transport. Evidence from stratigraphic exposures and augering transects indicates that channels and flood plains had stable altitudes or were slowly aggrading as a consequence of channel migration, avulsion, flood-plain deposition, and peat accumulation. In conjunction with aggrading main-stem flood plains, active geomorphic surfaces graded to the flood plain - including flanking bottomlands, active tributary fans and flood plains, and colluvial slopes - probably also have widened and aggraded during the last several thousand years.

\section{Valley Segments}

The overall geomorphology of the Sprague River Basin and associated valley and flood-plain characteristics provides a basis for dividing the main-stem Sprague River corridor into nine valley segments. Additionally, the reaches of the North Fork Sprague River and South Fork Sprague River within the study area each constitute defined valley segments. The lower $24 \mathrm{~km}$ of the Sycan River has been divided into two segments - the steep and confined Coyote Bucket valley segment where the river cuts through the Basalt of Knot Tableland, and the less confined Lower Sycan valley segment downstream to its convergence with the Sprague River flood plain.

Distinguishing valley segments provides an analysis framework for evaluating conditions and processes relative to overarching controls such as slope, confinement, history, and materials. If defined valley segments correspond with process regimes, segment-specific understanding can enable more efficient and targeted management for ecological objectives.

The main criteria for defining valley segments are valley confinement, major confluences, and channel slope. Current channel and flood-plain morphologic conditions, as summarized in the following accounts of individual segments (table 2; figs. 16-18), were assessed primarily from mapping based on year 2000 aerial photographs and the 2004 lidar data.

\section{Chiloquin Canyon}

The Chiloquin Canyon valley segment (fig. 19) extends from near the historical Braymill mill to the confluence of the Sprague and Williamson Rivers. The town of Chiloquin occupies a terrace, of either Sprague or Williamson River

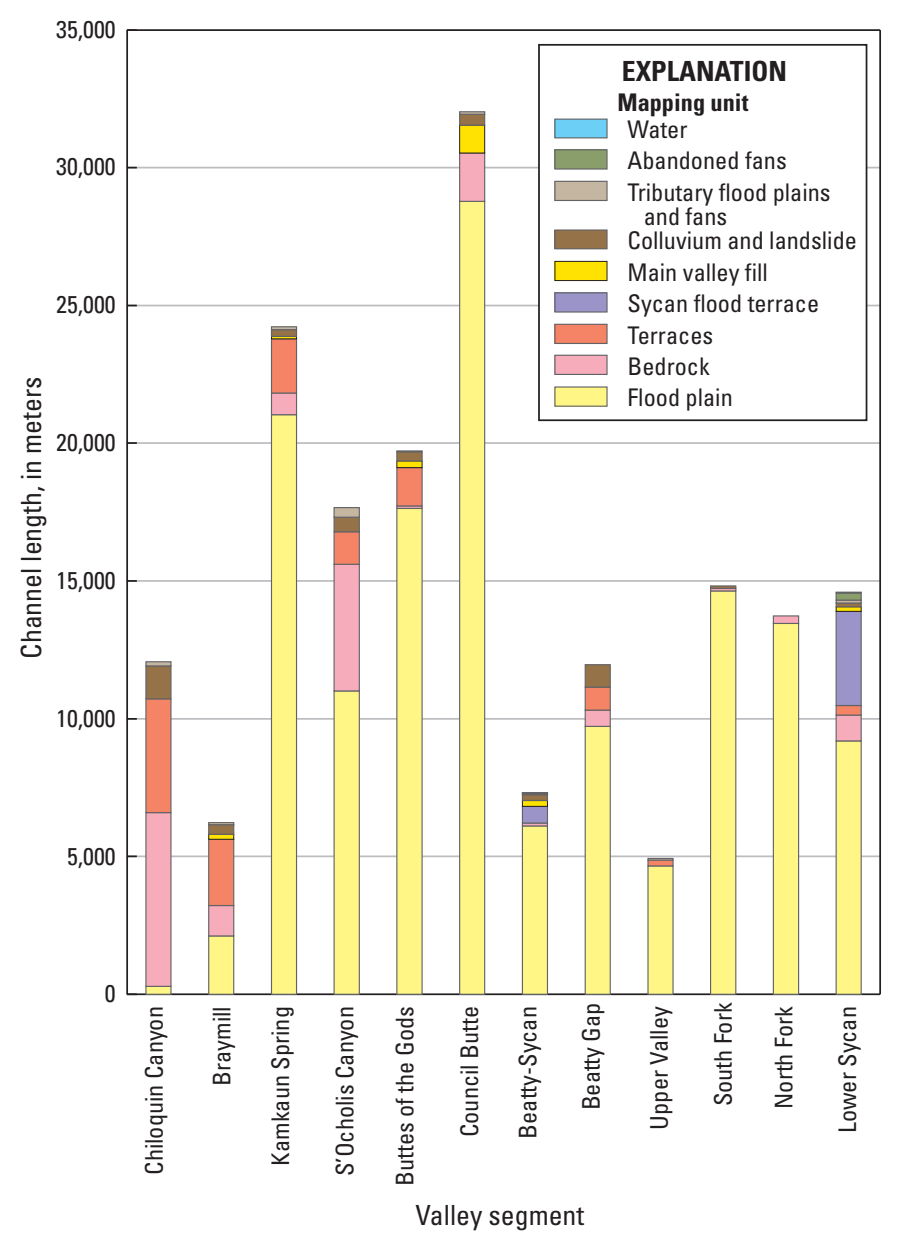

Figure 16. Geomorphic units within 10 meters of primary channel edge for channel location during 2000, Sprague River Basin, Oregon.

origin, north of the Sprague River flood plain. The upstream end of the valley segment is marked by the substantial slope change at FK 11.4, $1.2 \mathrm{~km}$ downstream of Braymill at FK 12.6 (fig. 17). Most of this segment is tightly confined by upfaulted volcanic rocks (fig. 16), resulting in a narrow flood plain (mean width $99 \mathrm{~m}$ ) containing a steep (slope 0.00195 ) boulder- and cobble-bed channel (fig. 19). Many terrace levels, as high as $45 \mathrm{~m}$, locally flank the flood plain. This reach is the steepest of all the main-stem Sprague River Valley segments, probably representing local tectonic uplift and tilting. The low-flow channel averages $37.8 \mathrm{~m}$ in width, occupying about 40 percent of the geomorphic flood plain (table 2; fig. 18). Channel sinuosity is low at 1.06, as measured relative to the flood plain centerline. The flood plain has a mixed vegetation cover of herbaceous vegetation, shrubs, and ponderosa pine with local cottonwood (Populus sp.) and aspen (Populus tremuloides). 


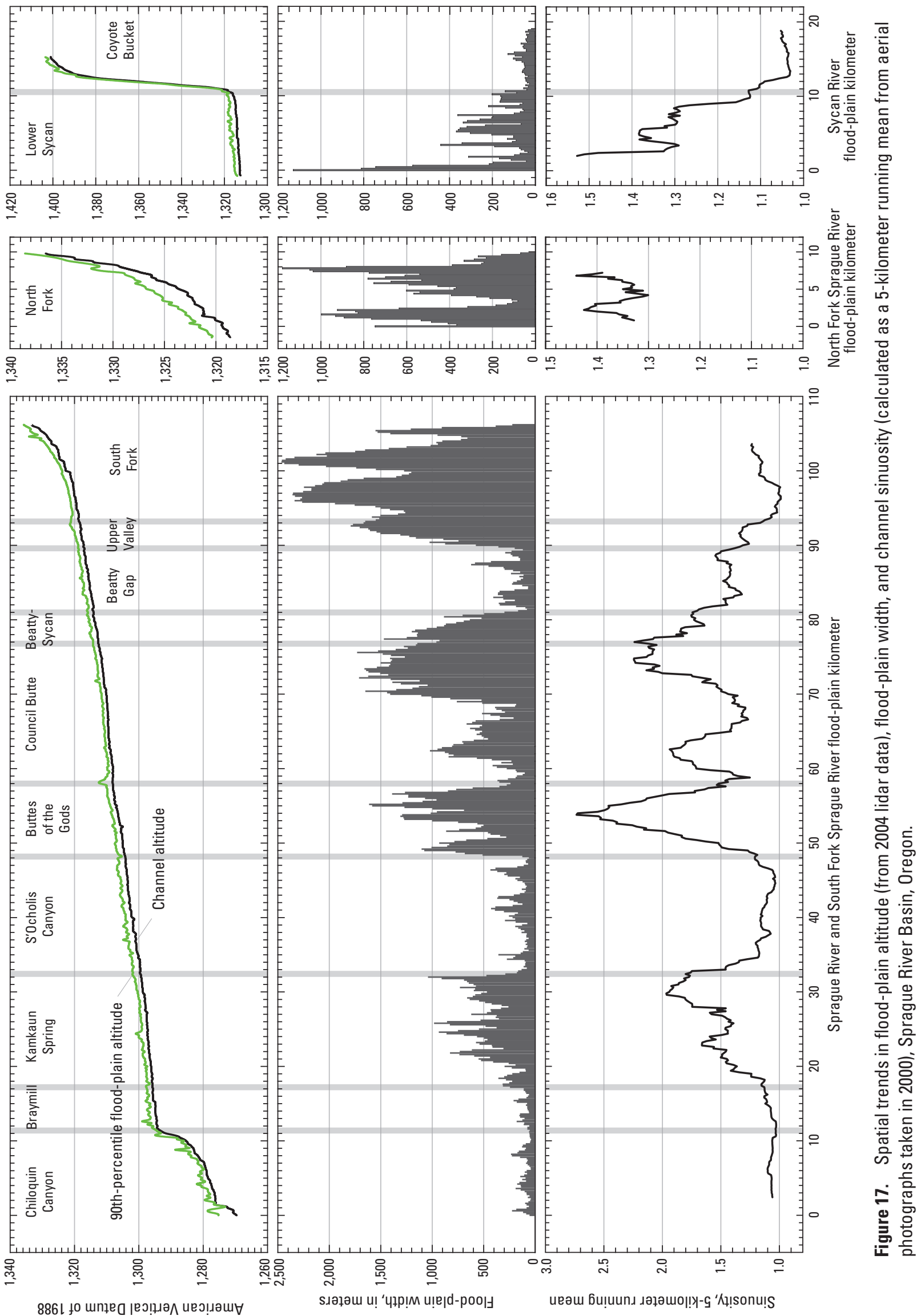

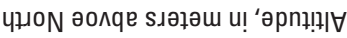



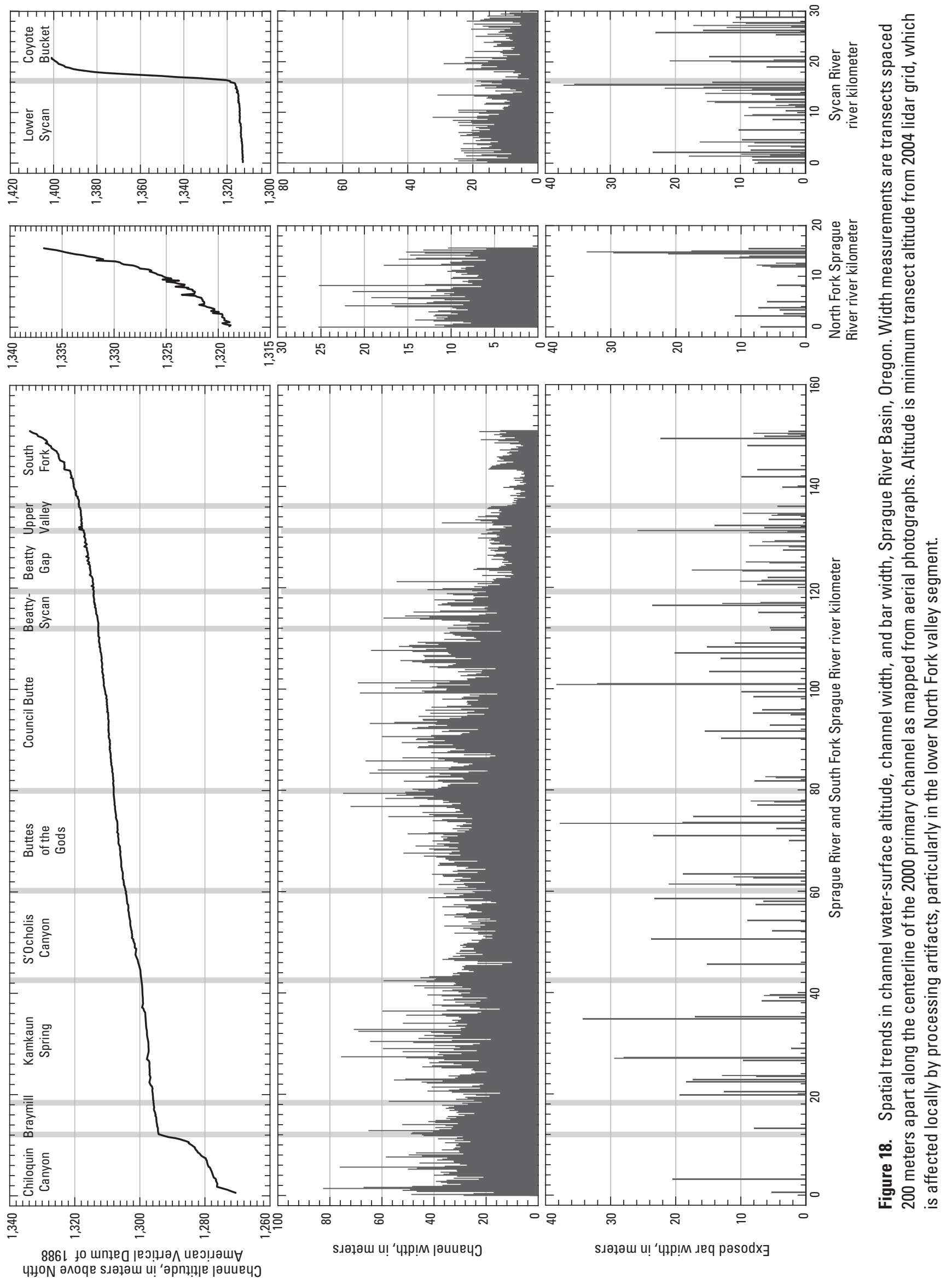
$\boldsymbol{A}$

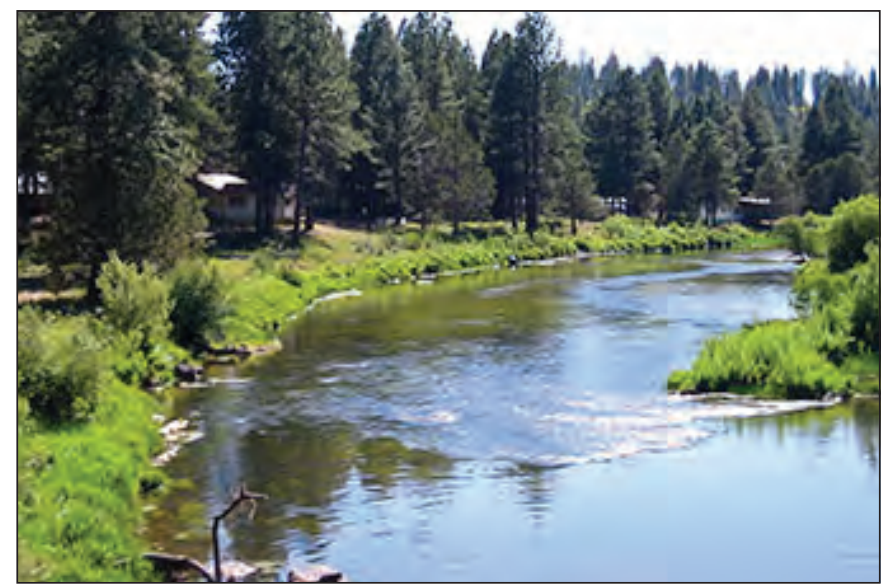

B

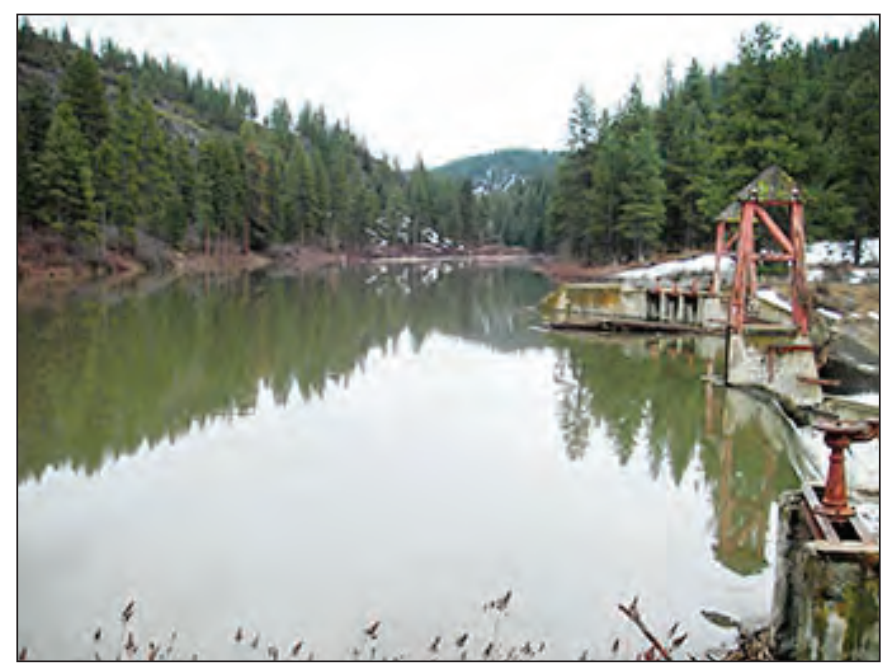

Figure 19. Chiloquin Canyon valley segment with $(A)$ view downstream of bridge crossing at flood-plain kilometer (FK) 8.8 (July 14,2005$)$, and $(B)$ view upstream across pool behind the decommissioned Chiloquin Dam at FK 1.3 (April 3, 2006), Sprague River Basin, Oregon. Photographs taken by J.E. O'Connor, U.S. Geological Survey.

A part of this valley segment is flanked by County Highway 858, which locally encroaches onto the flood plain between FK 9.5 and 11.4. The channel also was affected by Chiloquin Dam at FK 1.3 (fig. 19B), a water supply diversion structure constructed in 1914 and removed in August 2008. A bridge formerly spanned the flood plain and channel at FK 0.7. This valley segment contains USGS streamflow-gaging station 11501000 (Sprague River near Chiloquin, Oregon), at FK 8.3, which has been at this location since 1931, continuously operated with a previous location upstream at FK 28.6 since 1921. An earlier gaging station at about FK 0.7 near the town of Chiloquin (fig. 20) had continuous records for the period 1912-1919, with occasional measurements through 1925 (USGS Oregon Water Science Center, Portland, Oregon, measurement station records for station 11502000, Sprague River at Chiloquin, Oregon).

\section{$\boldsymbol{A}$}

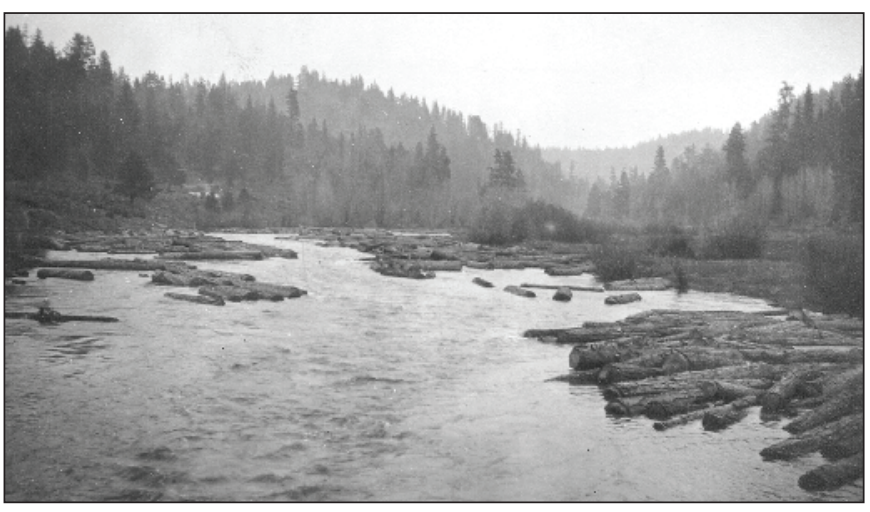

B

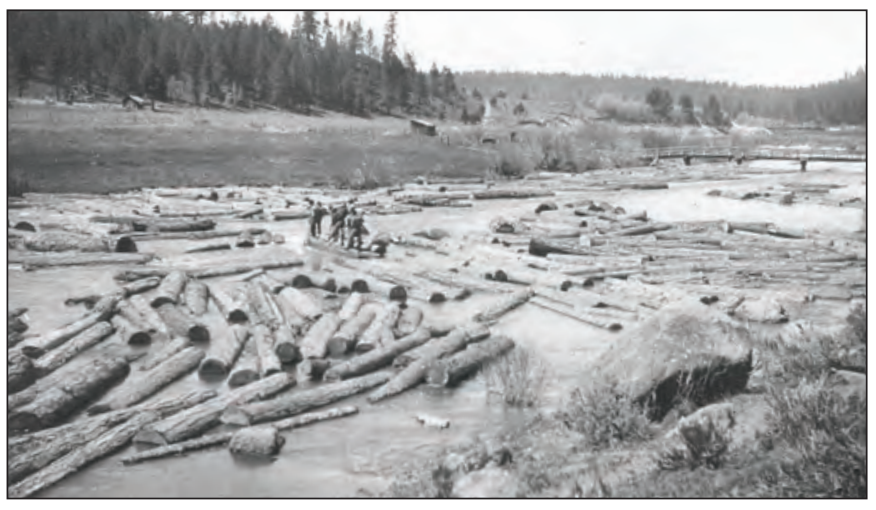

c

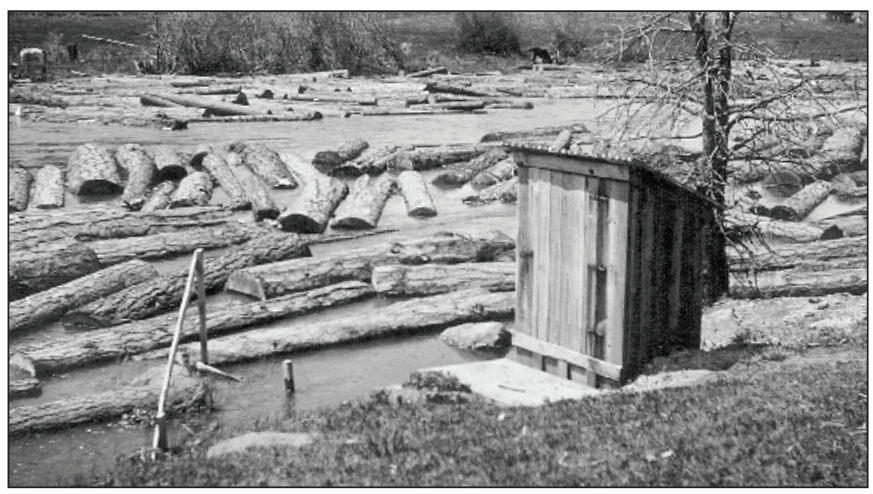

Figure 20. Historical photographs associated with discontinued U.S. Geological Survey (USGS) streamflow-gaging station 11502000 at flood-plain kilometer (FK) 0.7, with $(A)$ view upstream from former wagon bridge crossing of the Sprague River at FK 0.7 (May 2 (?), 1918; date not specifically noted, but indicated by accompanying notes); $(B)$ view downstream from near USGS gaging station (May 6, 1918); bridge visible in upper right of image); and $(C)$ view of USGS gage house on right bank of Sprague River near Chiloquin, Oregon. 
Near the upstream end of the Chiloquin Canyon valley segment, Medicine Rock Cave (Archeological site 35KL8; near FK 10.9) was noted by Spier (1930, p. 14) near the location of the site of the Klamath "First Sucker Ceremony" celebrating the annual spring migration of this fish. As noted in section, "Sycan Flood Deposits," this site contained evidence of fluvial deposition soon after the Mazama eruption (Cressman and others, 1956) that we attribute to the Sycan flood. Substantial sucker spawning has been observed in recent years between FKs 0 and 1.2 at the lower end of this valley segment (Ellsworth and others, 2007).

\section{Braymill}

The Braymill valley segment also is a narrow canyon segment (fig. 21), but is distinguished from the Chiloquin Canyon valley segment by its much flatter gradient -0.00024 compared to the eight-times-steeper slope of the Chiloquin Canyon valley segment (fig. 17, table 2). The Braymill valley segment extends $5.8 \mathrm{~km}$ from the valley contraction at FK 17.2 to the slope inflection at the head of the Chiloquin Canyon segment at FK 11.4. Within this reach, the flood plain averages $110 \mathrm{~m}$ in width and is flanked by bedrock, colluvial slopes, narrow flood-plain surfaces, and terraces rising $10 \mathrm{~m}$ higher than the channel (fig. 16). As with the Chiloquin Canyon valley segment, sinuosity is low (1.07) and the low-flow channel occupies about one-third of the total flood-plain width. Vegetation within the geomorphic flood plain also is similar to that of the Chiloquin Canyon segment: predominantly herbaceous grasses and forbs, shrubs, and ponderosa pine.

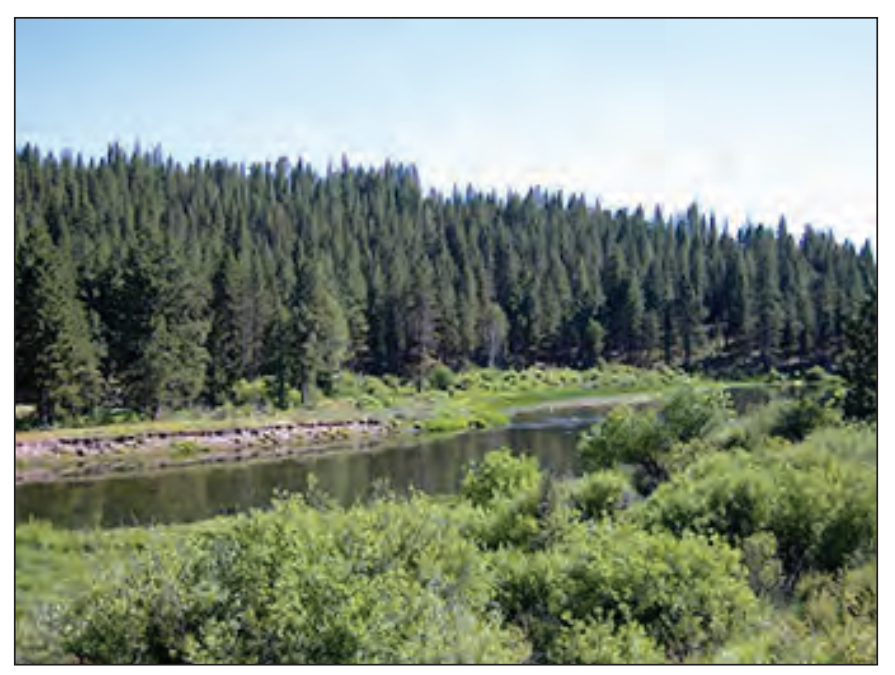

Figure 21. Braymill valley segment looking southwest from near flood-plain kilometer 14.5, Sprague River Basin, Oregon. Photograph taken by J.E. O'Connor, U.S. Geological Survey, July 14, 2005.
The Braymill valley segment is flanked and traversed by County Highway 858 and the Williamson River Road. County Highway 858 crosses the Sprague River at FK 15.5. Outbuildings and mill ponds associated with the decommissioned Braymill mill occupy the flood plain between FKs 12.5 and 12.6.

\section{Kamkaun Spring}

The Kamkaun Spring valley segment (fig. 22) extends $15.2 \mathrm{~km}$ from FK 32.4 at the downstream end of the S'Ocholis Canyon valley segment to the head of the Braymill valley segment at FK 17.2. This is a sinuous (1.59), low-gradient (slope 0.00015 ) reach with broad flood plains (fig. 17, table 2). The channel typically is some distance from valley margins (fig. 16). This segment locally is referred to as the "Nine Mile reach." The flood-plain and flanking main-stem valley fill are bounded by bedrock uplands and terraces as much as $7 \mathrm{~m}$ higher than the geomorphic flood plain. The average width of the geomorphic flood plain is $500 \mathrm{~m}$ (fig. 17), but this area of active channel migration for the last several thousand years is flanked by broad valleys and basins (chiefly mapped as main-stem valley fill; plate 1) that also are inundated during the largest floods. The Sprague River meanders through the flood plain (which in turn is sinuous) and has left several oxbow ponds and abandoned channels. The average channel width is about $33.8 \mathrm{~m}$ (table 2; fig. 18), and the channel mostly flows on sand and gravel, but also in places flows on indurated clay and silt locally scoured into several-meter-deep holes and chutes. Former fords and irrigation diversions are marked by placed rock and coarse gravel accumulations spanning the channel. Flood-plain vegetation is composed chiefly of herbaceous grasses and forbs, with abundant shrubs and local tree-form willows (Salix sp.).

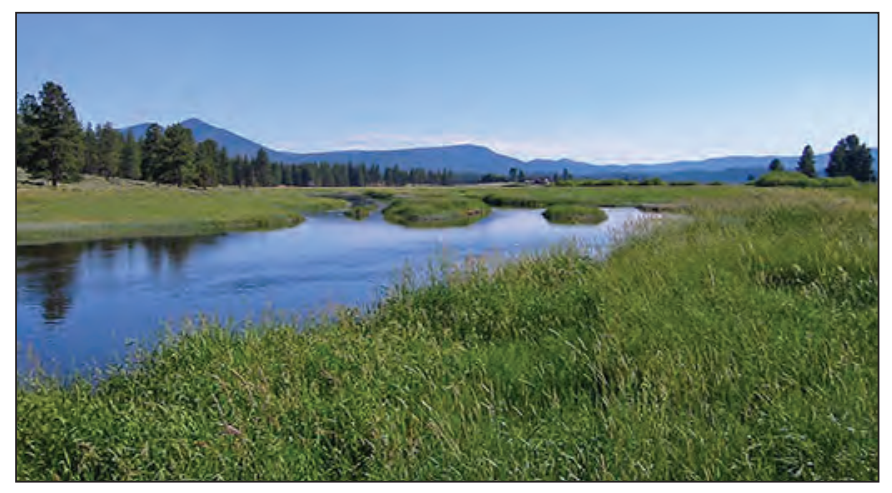

Figure 22. Kamkaun Spring valley segment at flood-plain kilometer 26.8, Sprague River Basin, Oregon. Photograph taken by J.E. O'Connor, U.S. Geological Survey, June 25, 2006. 
Several large spring complexes supplement river flow in this reach, including those at FKs 32.1 (McCready Springs), 30.2 (Kamkaun Spring), 25.5 (Lalo Springs), and at Whitehorse Springs, which enters the flood plain from the north at FK 22.0. Together, these springs add $1.95 \mathrm{~m}^{3} / \mathrm{s}$ of flow to the Sprague River (Gannett and others, 2007), accounting for 12 percent of the annual flow. These spring complexes and associated pools and channels that carry flow from the springs to the river create diverse aquatic habitats that may be important for sucker spawning and rearing, as indicated by concentrated adult sucker movement in this reach (Ellsworth and others, 2007).

These spring complexes provide a reliable water source and inhibit the Sprague River from freezing over, which, along with the wide flood plains, have led to a long history of settlement in this reach. Archeological sites on terraces and hillslopes flanking the flood plain in this reach possibly date back to more than 8,000 years ago (Spier, 1930; Cressman and others, 1956; Butler and others, 2010). Early homesteaders began cattle ranching here at about the time Frank McCready settled in 1915 on the peninsula of the terrace jutting into the flood plain between FKs 31.9 and 28.7 (Greg Harris, Frank McCready's grandson and present landowner, oral commun., September 13, 2007). To enable cattle ranching and flood-plain irrigation, diversion dams and ditches were emplaced within this reach by the mid-1920s (USGS Oregon Water Science Center, Portland, Oregon, measurement station records for station 11501000). Construction of the OC\&E railroad to Bly and concurrent logging also proceeded through this reach in the 1920s, with the railroad grade effectively diking parts of the flood plain. More systematic levee construction and willow eradication began during 1953-54, when the U.S. Army Corps of Engineers constructed levees and dikes by excavating directly from the channel (Greg Harris, oral commun., 2007). More recent channel and flood-plain modifications in this segment include filling of meander cutoffs and associated bank stabilization, and local levee breaching (fig. 23).

\section{S'Ocholis Canyon}

The S'Ocholis Canyon valley segment (fig. 24) encompasses $15.8 \mathrm{~km}$ of confined canyon and narrow valley between the much wider Buttes of the Gods and Kamkaun Spring valley segments. Its upstream boundary (FK 48.2) is close to the confluence of Trout Creek and the Sprague River at FK 48.0. The geomorphic flood plain averages $170 \mathrm{~m}$ wide and is everywhere less than $500 \mathrm{~m}$ wide (table 2; fig. 17). The flood plain is flanked mostly by steep bedrock and colluvium-mantled hillslopes, low terraces of as much as $5 \mathrm{~m}$ higher than the active flood plain, and tributary flood plains and fans (fig. 16). The flood plain is slightly wider between FKs 39.4 and 43.2, where it is confined by low terraces and where a large area of main-stem valley fill is contiguous to the geomorphic flood plain between FKs 42.3 and 42.6.

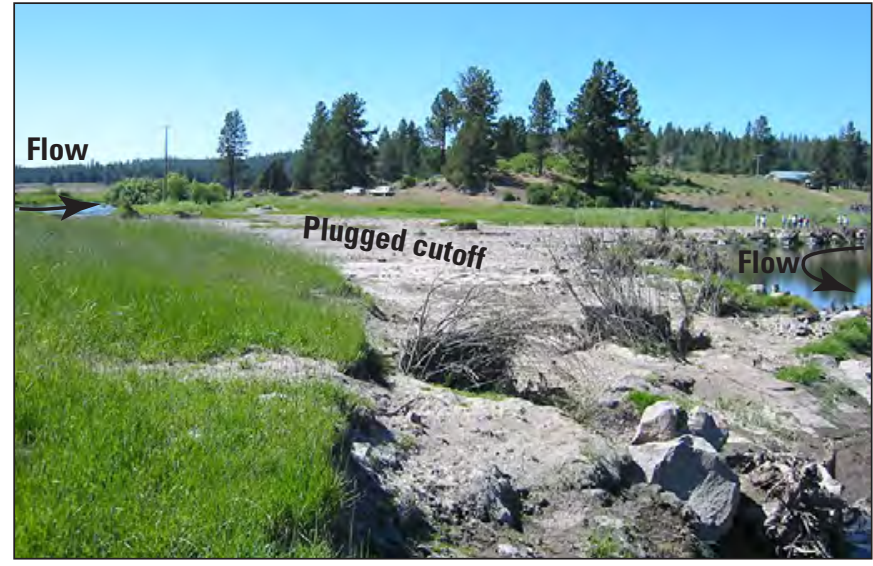

Figure 23. Filled cutoff channel at flood-plain kilometer 25.3, Kamkaun Spring valley segment, Sprague River Basin, Oregon. The upstream outside bend of rechannelized meander bend (right part of photograph) is protected with rock-anchored wood. Photograph taken by J.E. O'Connor, U.S. Geological Survey, June 22, 2006.

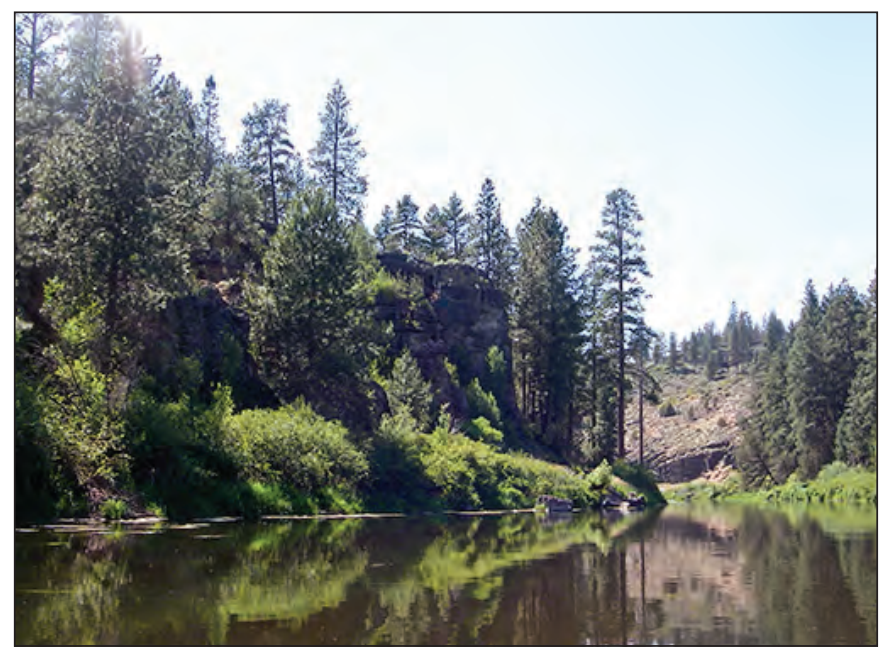

Figure 24. $S^{\prime} 0$ cholis Canyon valley segment at flood-plain kilometer 34.1, Sprague River Basin, Oregon. Photograph taken by J.E. O'Connor, U.S. Geological Survey, July 15, 2006.

Within this valley segment, the channel averages $27.7 \mathrm{~m}$ in width, has a sinuosity of 1.12 , and has a slope of 0.00027 substantially less sinuous and slightly narrower and steeper than the alluvial segments upstream and downstream (table 2 , fig. 18). The channel bed is composed primarily of sand and gravel, locally colonized by dense aquatic growth during summer low-flow periods. The flood plain is vegetated with herbaceous vegetation and shrubs (including locally thick willow patches, particularly in wide reaches), with some ponderosa pine and sparse aspen patches. 
Human disturbance has had few effects on this reach. A rock accumulation associated with an old channel crossing forms a low-flow riffle at FK 35.8. Bridges presently span the channel at FKs 34.3 and 40.7. County Highway 858 flanks the channel and flood plain between FKs 34.3 and 42.3, passing through the Lone Pine community on a low terrace north of the Sprague River at about FK 40.5. Unpaved forest tracks parallel the channel in the confined canyon reaches. Most of the flood plain in this valley segment is not actively cultivated, but is locally grazed.

\section{Buttes of the Gods}

The Buttes of the Gods valley segment (fig. 25) extends $9.8 \mathrm{~km}$ from the town of Sprague River at FK 58.0 to the head of the S'Ocholis Canyon segment near the Trout Creek confluence at FK 48.2. The upstream segment boundary is defined by the valley constriction and change in slope (figs. 17, 18) where abandoned fan surfaces sloping from the south encroach against the downstream end of the Basalt of Knot Tableland and underlying Tertiary lacustrine sediment. The expansive flood plain of this valley segment is bound by terraces, alluvial fans, and pediments, many of which are abandoned and incised (pl. 1). The 2000 channel is within $10 \mathrm{~m}$ of the valley margin for less than 10 percent of its length (fig. 16). The highest terraces are as much as $8 \mathrm{~m}$ higher than the present channel. Large areas of main-stem valley fill, possibly inundated at high flows, occupy valleys marginal to the geomorphic flood plain. Locally, colluvium descends to flood-plain and terrace surfaces from isolated volcanic buttes and the broad mesa underlain by the Basalt of Knot Tableland north of the Sprague River.

The geomorphic flood plain averages $870 \mathrm{~m}$ wide, with the channel averaging $35.8 \mathrm{~m}$ wide (figs. 17, 18). Channel slope for this valley segment is 0.00019 , less than that of the S'Ocholis Canyon valley segment downstream, but distinctly steeper than the upstream Council Butte valley segment. Channel sinuosity is 2.01 , greatest of all the valley segments (table 2). The channel substrate is composed of patchy sand and gravel over indurated silt and clay. Ledges of this silt and clay locally form small drops at low flow. The induration and extensive jointing within the clay and silt indicate that this sediment is Tertiary lacustrine sediment rather than Quaternary fluvial sediment.

The flood plain for the Buttes of the Gods valley segment has very few large trees and just a few, isolated willow patches, mainly at the downstream end of the reach between FKs 48.2 and 49.7. The flood plain is mostly covered with herbaceous vegetation, including irrigated pasture grasses. Riparian vegetation mainly is composed of sedges, rushes, and riparian grasses. Although few roads and structures occupy the flood plain, this valley segment has been extensively modified by levees, irrigation ditches, and, historically, diversion structures and impoundments associated with flood-plain

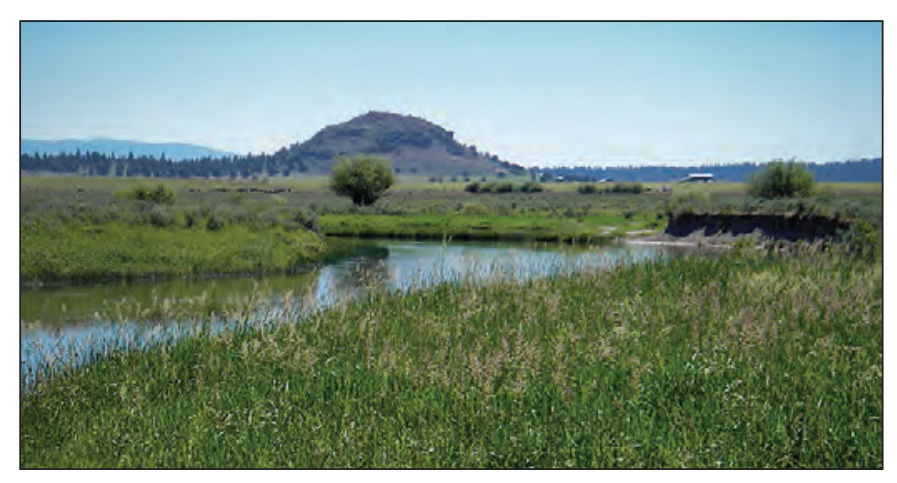

Figure 25. Buttes of the Gods valley segment looking upstream from flood-plain kilometer 49.2, Sprague River Basin, Oregon. Photograph taken by J.E. O'Connor, U.S. Geological Survey, June 28, 2005.

irrigation as well as lumber mill activities in the town of Sprague River. No bridges cross the Sprague River and no paved roads are within the geomorphic flood plain of the Buttes of the Gods valley segment.

\section{Council Butte}

The Council Butte valley segment is another wide valley segment (fig. 26) that, together with the Buttes of the Gods segment, encompasses most of the area known as the Sprague River Valley. The Council Butte segment stretches $18.8 \mathrm{~km}$ from the Sycan River confluence at FK 76.8 to the valley constriction and distinct channel-slope increase at FK 58.0, coinciding with the town of Sprague River and the crossing of the Sprague River by the Sprague River Road. The geomorphic flood plain averages $840 \mathrm{~m}$ in width, but narrows substantially near Council Butte (at FK 66.4) and near the downstream end of the valley segment where it locally is less than $100 \mathrm{~m}$ wide (fig. 17).

For much of its length, the 70-m-high mesa underlain by the Basalt of Knot Tableland and southward-descending colluvial slopes and tributary fans border the north side of the flood plain. The geomorphic flood plain is bounded on the south by main-stem valley fill, low terraces, active and abandoned alluvial fans, and locally by colluvial slopes and bedrock associated with Council Butte and other bedrock uplands. Incised fans emanating from Bly Mountain and surrounding uplands encroach upon the flood plain at the west end of the valley segment, narrowing the flood plain. The upstream end of this segment abuts the Sycan River flood plain as well as pumice-rich deposits of the Sycan flood.

The channel within the Council Butte valley segment averages $35.0 \mathrm{~m}$ in width, is sinuous (1.70), and has a gradient of 0.00015 , which, along with the similarly low-gradient Kamkaun Spring valley segment, is the flattest in the study 


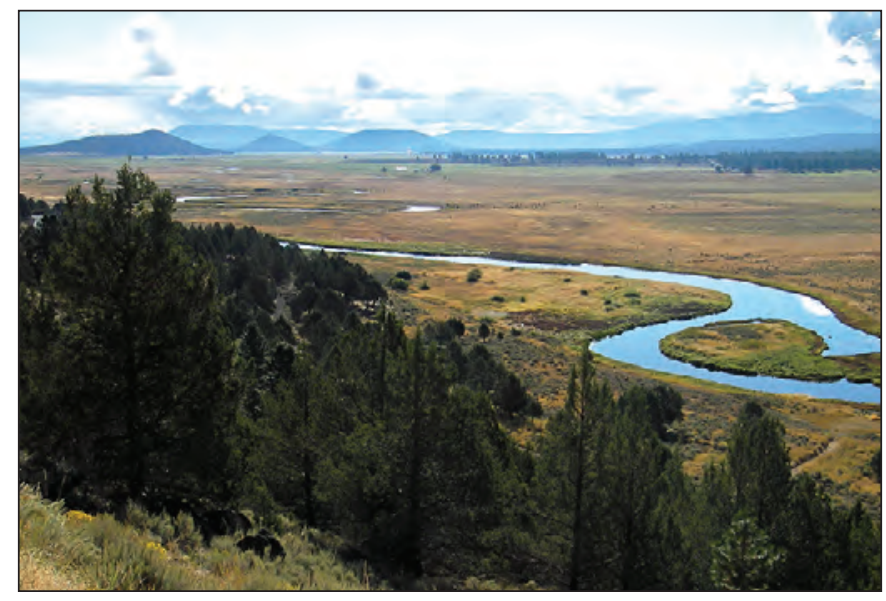

Figure 26. Council Butte valley segment looking upstream from near flood-plain kilometer 59.2, Sprague River Basin, Oregon. Photograph taken by J.E. O'Connor, U.S. Geological Survey, September 16, 2006.

area (table 2; figs. 17, 18). The channel substrate varies from mainly sand with sparse gravel near the Sycan River confluence with the Sprague River to patchy sand over mud and clay at the downstream end of the reach. Except for a rocky ford that spans the channel at FK 76.3, there is little gravel in the channel or banks. At low flow, velocity is slow and the channel is rimmed by dense sedge-rush communities, and locally by several large wapato (Sagittaria cuneata) colonies. The flood plain is treeless, has very few shrubs, and is vegetated mainly by pasture grass that is irrigated in places. Levees, dikes, and dry flood-plain patches are vegetated with sagebrush and grass.

The Council Butte valley segment has been modified extensively by ditches, levees, bank protection, and farm road construction. The total length of such features in 2000 was $76.3 \mathrm{~km}$, most of which were constructed during 1940-68 (table 6). The railroad grade, constructed in the 1920s, locally encroaches onto the southern edge of the geomorphic flood plain and flanking main-stem valley fill. Since the 1990s, as part of channel restoration efforts, meander cutoffs and secondary channels have been plugged and armored with rock and large wood near FKs 61.4 and 76.2.

\section{Beatty-Sycan}

The Beatty-Sycan valley segment (fig. 27) is a short reach extending $4.2 \mathrm{~km}$ from the downstream end of Beatty Gap at FK 81.0 to the Sycan River confluence with the Sprague River at FK 76.8. Like the two downstream segments, this is a wide and unconfined reach containing a sinuous (1.68) Sprague River. This segment constitutes the upper part of the Sprague River Valley. The geomorphic flood plain averages $910 \mathrm{~m}$ wide (table 2, fig. 17) and is mostly bounded by main-stem valley fill that probably is inundated during large

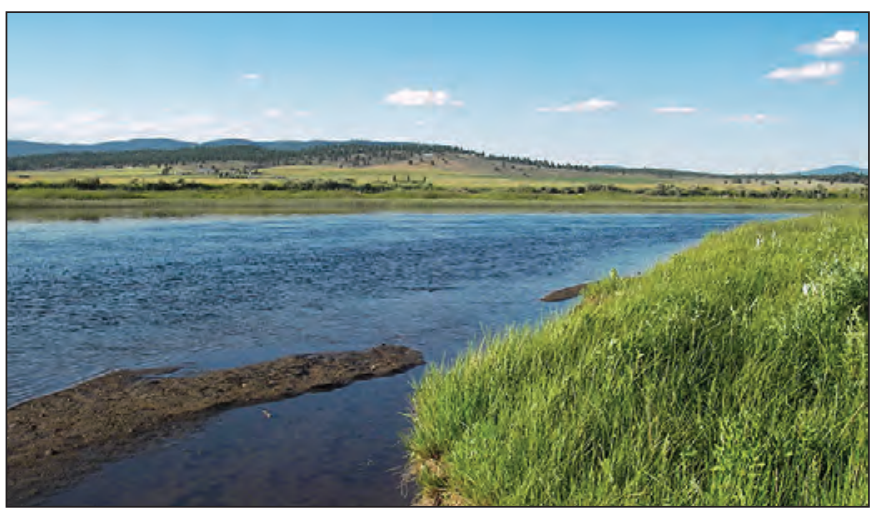

Figure 27. Beatty-Sycan valley segment looking northwest (upstream) from flood-plain kilometer 78.5, Sprague River Basin, Oregon. Photograph taken by J.E. O'Connor, U.S. Geological Survey, June 26, 2006.

floods, as well as active and incised tributary fans and flood plains. The valley of Brown Creek enters from the south at FK 80.7 , adjacent to the large spring complex known locally as Medicine Springs, which contributes about $0.4 \mathrm{~m}^{3} / \mathrm{s}$ of flow to the Sprague River (Gannett and others, 2007). In total, springs in the upper part of this valley segment add about $1.6 \mathrm{~m}^{3} / \mathrm{s}$ of flow to the Sprague River (Gannett and others, 2007), thereby augmenting the annual flow by 18 percent from that measured just upstream at Beatty Gap (streamflow gaging station 11497500).

In this valley segment, the channel chiefly is flanked by flood-plain deposits, averages $29.4 \mathrm{~m}$ in width, and has a slope of 0.00021 (table 2; figs. 18, 16). The channel substrate mostly is sand but locally is muddy. During the June 26, 2006 canoe reconnaissance of this reach, abundant freshwater mussels were noted in the channel bed near FK 79.2 (which subsequently has been filled and relocated as a part of channel-restoration activities). The channel margin mostly is vegetated with sedges, rushes, and some grasses. Willow clumps have grown on a few point bars and along the edges of former channel routes. Otherwise, the flood plain is vegetated with pasture grass, with dry parts hosting sagebrush and xeric grasses.

As with most of the other wide valley segments, the Beatty-Sycan valley segment has been modified by ditches and levees, although the density of such features, particularly levees, is less in this reach than the other wide valley segments. Godawa Springs Road crosses the Sprague River and the flood plain at FK 78.0. The flood plain is flanked and crossed at FK 80.9 by the OC\&E railroad grade, and crossed by the Woods Line branch at FK 80.6, where the trestle bridge effectively traps most wood from upstream. Channel restoration projects during 2006-08 filled three channel cutoffs and excavated a new channel near FK 78.8-79.4. 
Table 6. Mapped built features in the Sprague River geomorphic flood plain, Oregon.

[Abbreviations: km, kilometer; ha, hectare]

\begin{tabular}{|c|c|c|c|c|c|c|c|c|c|}
\hline \multirow[t]{2}{*}{$\begin{array}{c}\text { Valley } \\
\text { segment }\end{array}$} & \multicolumn{3}{|c|}{$\begin{array}{c}\text { Ditches } \\
(\mathbf{k m})\end{array}$} & \multicolumn{3}{|c|}{$\begin{array}{l}\text { Dikes and } \\
\text { levees } \\
\text { (km) }\end{array}$} & \multicolumn{3}{|c|}{$\begin{array}{c}\text { Roads } \\
\text { (km) }\end{array}$} \\
\hline & 1940 & 1968 & 2000 & 1940 & 1968 & 2000 & 1940 & 1968 & 2000 \\
\hline Chiloquin Canyon & 1.0 & 1.0 & 0.0 & 0.3 & 0.0 & 0.6 & 2.5 & 0.4 & 0.7 \\
\hline Braymill & 0.0 & 0.0 & 0.0 & 0.0 & 0.0 & 0.0 & 0.2 & 0.2 & 0.2 \\
\hline Kamkaun Spring & 1.7 & 30.5 & 31.6 & 0.1 & 4.1 & 9.0 & 0.0 & 0.7 & 2.1 \\
\hline $\mathrm{S}^{\prime}$ Ocholis Canyon & 0.0 & 10.0 & 1.2 & 0.0 & 0.5 & 0.2 & 2.2 & 1.8 & 2.9 \\
\hline Buttes of the Gods & 2.8 & 16.7 & 34.7 & 1.9 & 13.1 & 16.9 & 0.1 & 1.4 & 0.9 \\
\hline Council Butte & 0.3 & 31.5 & 42.7 & 0.0 & 19.0 & 25.6 & 1.9 & 3.0 & 8.0 \\
\hline Beatty-Sycan & 0.0 & 5.8 & 12.2 & 0.0 & 0.0 & 0.6 & 3.1 & 4.0 & 2.8 \\
\hline Beatty Gap & 0.0 & 0.0 & 0.0 & 0.0 & 0.0 & 0.0 & 1.0 & 1.1 & 1.9 \\
\hline Upper Valley & 1.2 & 24.3 & 23.5 & 0.0 & 8.1 & 8.1 & 0.0 & 0.3 & 0.3 \\
\hline South Fork & ${ }^{1} 1.1$ & 126.3 & 123.7 & ${ }^{1} 0.0$ & 58.8 & 81.1 & ${ }^{1} 1.2$ & 8.6 & 7.2 \\
\hline North Fork & ${ }^{1} 3.9$ & 21.7 & 22.7 & ${ }^{1} 0.0$ & 5.6 & 8.9 & ${ }^{1} 1.8$ & 3.2 & 3.8 \\
\hline Lower Sycan & 0.0 & 4.7 & 2.3 & 0.0 & 0.0 & 0.5 & 0.9 & 2.0 & 1.3 \\
\hline Study Area & ${ }^{1} 11.9$ & 272.3 & 294.6 & 12.2 & 109.3 & 151.5 & ${ }^{1} 14.9$ & 26.8 & 32.0 \\
\hline \multirow[t]{2}{*}{$\begin{array}{c}\text { Valley } \\
\text { segment }\end{array}$} & \multicolumn{3}{|c|}{$\begin{array}{l}\text { Dams and } \\
\text { diversion } \\
\text { structures } \\
\text { (number) }\end{array}$} & \multicolumn{3}{|c|}{$\begin{array}{l}\text { Buildings and } \\
\text { structures } \\
\text { (number) }\end{array}$} & \multicolumn{3}{|c|}{$\begin{array}{c}\text { Total } \\
\text { built area } \\
\text { (ha) }\end{array}$} \\
\hline & 1940 & 1968 & 2000 & 1940 & 1968 & 2000 & 1940 & 1968 & 2000 \\
\hline Chiloquin Canyon & 1 & 1 & 1 & 1 & 4 & 1 & 2.1 & 1.0 & 0.7 \\
\hline Braymill & 0 & 0 & 0 & 3 & 3 & 3 & 0.4 & 0.3 & 0.3 \\
\hline Kamkaun Spring & 0 & 0 & 2 & 0 & 0 & 1 & 0.3 & 7.1 & 11.0 \\
\hline $\mathrm{S}^{\prime}$ Ocholis Canyon & 0 & 0 & 0 & 0 & 0 & 0 & 1.1 & 1.9 & 1.7 \\
\hline Buttes of the Gods & 10 & 13 & 19 & 3 & 1 & 3 & 2.2 & 13.9 & 18.2 \\
\hline Council Butte & 1 & 11 & 11 & 5 & 0 & 1 & 1.5 & 26.5 & 36.0 \\
\hline Beatty-Sycan & 0 & 0 & 0 & 0 & 3 & 5 & 2.6 & 4.3 & 4.5 \\
\hline Beatty Gap & 0 & 0 & 0 & 0 & 0 & 0 & 0.8 & 0.7 & 1.1 \\
\hline Upper Valley & 0 & 0 & 0 & 0 & 0 & 0 & 0.1 & 11.5 & 11.3 \\
\hline South Fork & ${ }^{1} 0$ & 110 & 69 & ${ }^{1} 0$ & 1 & 0 & ${ }^{19.8}$ & 81.1 & 101.3 \\
\hline North Fork & ${ }^{1} 0$ & 17 & 17 & 15 & 2 & 4 & 132.0 & 8.9 & 12.8 \\
\hline Lower Sycan & 0 & 1 & 25 & 0 & 0 & 1 & 1.0 & 2.5 & 2.0 \\
\hline Study Area & ${ }^{1} 12$ & 153 & 144 & ${ }^{1} \mathbf{1 7}$ & 14 & 19 & ${ }^{1} 162.8$ & 159.7 & 200.9 \\
\hline
\end{tabular}

${ }^{1}$ Aerial photograph coverage incomplete.

\section{Beatty Gap}

The Beatty Gap segment encompasses the canyon between FKs 89.6 and 81.0 where the Sprague River flows between Ferguson and Medicine Mountains. The geomorphic flood plain is narrow, averaging $240 \mathrm{~m}$ wide (table 2, fig. 17), and is flanked by bedrock, colluvial slopes, small tributary fans and terraces of as much as $5 \mathrm{~m}$ higher than the modern channel. The channel in this segment averages only $17.3 \mathrm{~m}$ in width, about 60 percent the width of downstream Beatty-Sycan valley segment, and has a slightly steeper slope of 0.00024 compared to the Beatty-Sycan valley segment (table 2). Unlike the other canyon segments where sinuosity is less than 1.1, the Sprague River meanders through Beatty Gap with a sinuosity of 1.39 . The channel substrate mainly is sand, but locally contains gravel and cobbles, particularly where the channel is close to bedrock or colluvial slopes. In places, sand and gravel are thin or patchy on a clay bed. Locally, live freshwater mussels inhabited the channel bed during the June 2006 survey.

The flood plain has abundant shrub and tree cover, including willow, aspen, currant (Ribes L.), and rose (Rosa L.; fig. 28). Slightly higher and more xeric flood-plain surfaces are vegetated with sagebrush, rabbitbrush (Chrysothamnus Nutt.), and grasses. The channel margin and flanking point bars are vegetated with grasses, sedges, rushes, and common reed canarygrass. Wood accumulations, including some large ponderosa pine boles originating on adjacent hillslopes, locally flank and span the channel. 


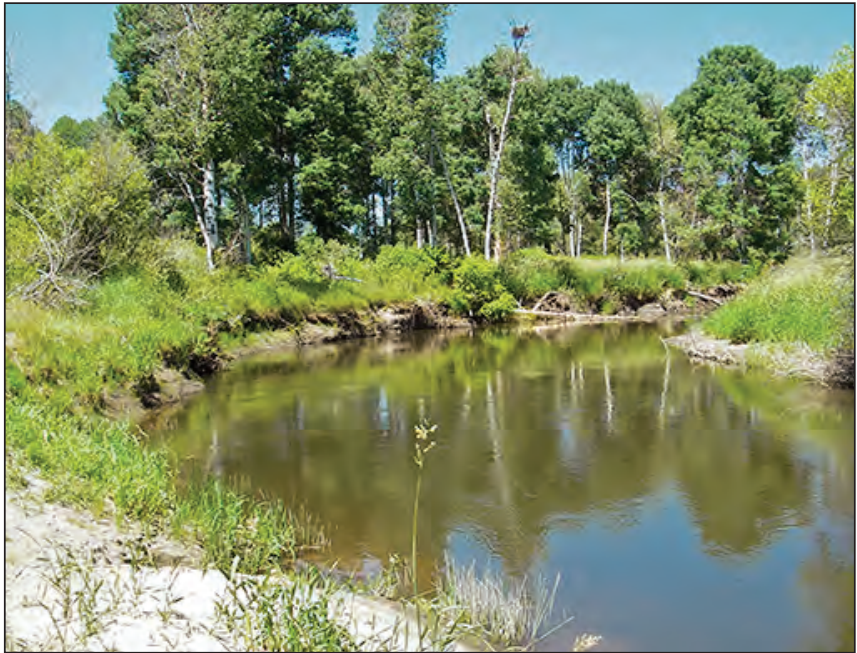

Figure 28. Beatty Gap valley segment looking west (downstream) from flood-plain kilometer 85.2, Sprague River Basin, Oregon. Photograph taken by J.E. O'Connor, U.S. Geological Survey, June 26, 2006.

Flow has been measured in the Beatty Gap valley segment episodically since about 1904 , but more continuously since 1912 by the USGS and then the OWRD (figs. 2, $\underline{3}$; USGS Oregon Water Science Center, Portland, Oregon, streamflow-gaging station records). Records from these stations and additional measurements and observations show that several springs supplement flow through Beatty Gap. Gannett and others (2007) reported $0.73 \mathrm{~m}^{3} / \mathrm{s}$ of spring inflow between the long-term Beatty Gap gaging station at FK 81.4 and near the 1912 gaging station at FK 84.2. However, additional springs upstream, including significant inflow at FK 85.0 and just upstream of the upstream segment boundary at FK 89.6, may contribute a similar volume, thereby accounting for nearly all the gain in flow estimated by Gannett and others (2007) for the upper Sprague River. The spring flow in this reach, as well as the spring flow at Medicine Springs near the downstream end of this valley segment, may have attracted early Native American settlement dating back 8,000 years (Jenkins and Connelly, 2007) — settlement that was sustained partly by Chinook and steelhead salmon (Butler and others, 2010). Spring flow in this reach also may be partly responsible for the present high levels of adult sucker activity (Ellsworth and others, 2007).

The Beatty Gap valley segment has few diversions, ditches, and levees. It is crossed by a private bridge at FK 89.3 and a concrete bridge along the OC\&E railroad grade at FK 87.7. Historically, a wagon road and later a highway crossing spanned the river at FK 81.5 (fig. 29). State Highway 140 traverses the southern edge of the flood plain, and the
$\boldsymbol{A}$

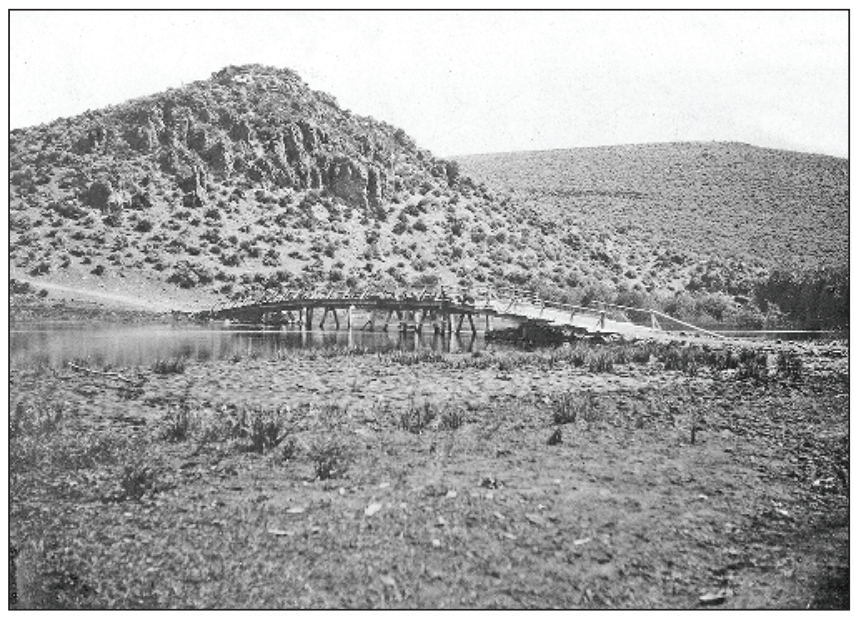

B

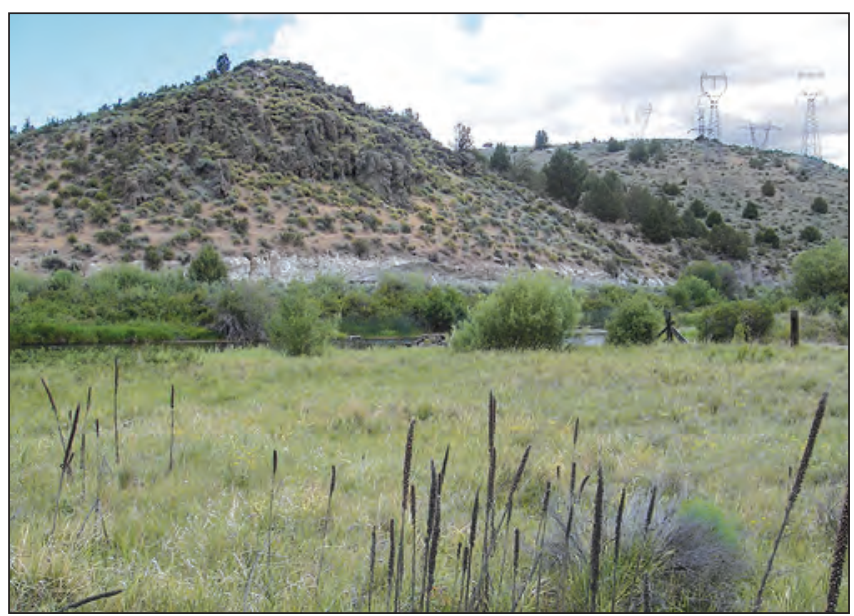

Figure 29. Approximately matched locations at flood-plain kilometer 81.4 near the downstream end of the Beatty Gap valley segment, Sprague River Basin, Oregon. (A) Former Beatty Bridge, photograph probably taken May 21, 1904, during establishment of streamflow-gaging station near present site of Oregon Water Resources Department station 11497500. (B) Photograph taken close to the same location on June 29, 2007, showing increase of riparian willow (Salix sp.), hillslope juniper (Juniperus occidentalis), and transmission towers. Source of figure 29A: Bureau of Reclamation, Klamath Waters Digital Library; http:// digitallib.oit.edu/cdm/singleitem/collection/kw//id/522/rec/5, accessed February 11, 2012). Figure $29 B$ taken by J.E. O'Connor, U.S. Geological Survey.

railroad grade and a private road flank parts of the northern flood-plain boundary. For most of the reach, however, these roadways do not significantly encroach upon the geomorphic flood plain, except for the upstream and downstream ends, where the railroad grade crosses and traverses the flood plain. 


\section{Upper Valley}

The Upper Valley segment (fig. 30) extends $3.6 \mathrm{~km}$ from the confluence of the North Fork and South Fork Sprague Rivers at FK 93.2 to the entrance of Beatty Gap at FK 89.6. This is a wide valley segment, with the flood plain averaging $1,280 \mathrm{~m}$ wide. The geomorphic flood plain mainly is flanked by active tributary fans, colluvial slopes, and low terrace deposits. The channel winds through the flood plain with an average width of $17.8 \mathrm{~m}$ and a sinuosity of 1.37 , and rarely encroaches the valley margins (table 2; figs. 16, 18). Channel slope for the Upper Valley segment (0.00033) is higher than for any main-stem Sprague River valley segment except for Chiloquin Canyon. The channel substrate chiefly is sand with local gravel accumulations. In places, the sand and gravel are patchy on top of indurated silt and clay. Many live freshwater mussels were colonizing the channel bed during the June 23, 2006, canoe reconnaissance.

Willow clumps locally flank the present channel as well as swales marking former channel locations, particularly between FKs 89.6 and 91.0. Otherwise, the channel corridor is vegetated with rushes, sedges, and reed canarygrass. The flood plain mainly is vegetated with pasture grasses, sage, and rabbitbrush.

Levees bound the channel on the north from FKs 89.7 to 92.3, and on the south from FKs 92.3 to 93.2. The flood plain also has many ditches and diversions and is locally leveled. The railroad grade flanks the southern margin of the channel, but mostly is outside the geomorphic flood plain.

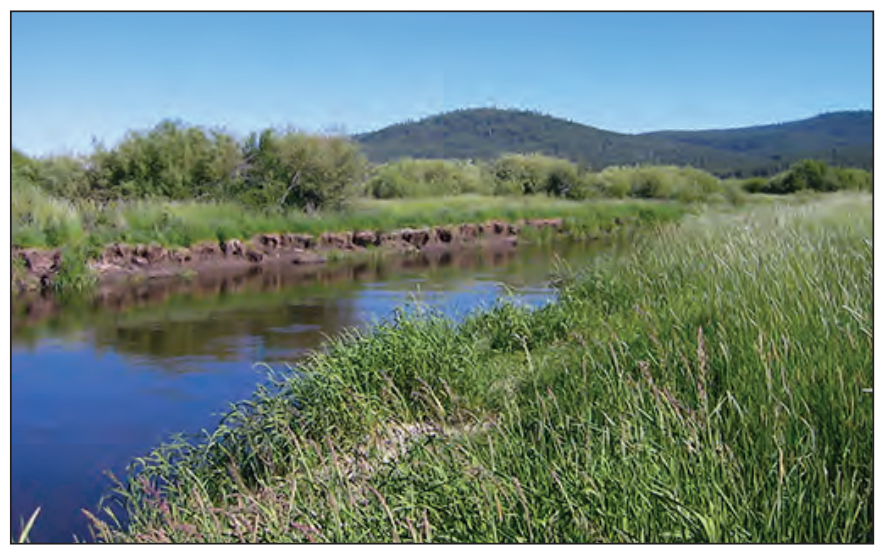

Figure 30. Upper Valley segment looking downstream from flood-plain kilometer 88.5, Sprague River Basin, Oregon. Photograph taken by J.E. O'Connor, U.S. Geological Survey, June 23, 2006.

\section{South Fork}

The South Fork valley segment (fig. 31) spans $13.1 \mathrm{~km}$ from FK 106.3, $5.7 \mathrm{~km}$ east-southeast of Bly, to FK 93.2, at the confluence of the South Fork Sprague River with the North Fork Sprague River. This segment encompasses the broad alluvial valley from where the river leaves the uplands dividing the Sprague River Basin from those basins to the east. The geomorphic flood plain is flanked by active and

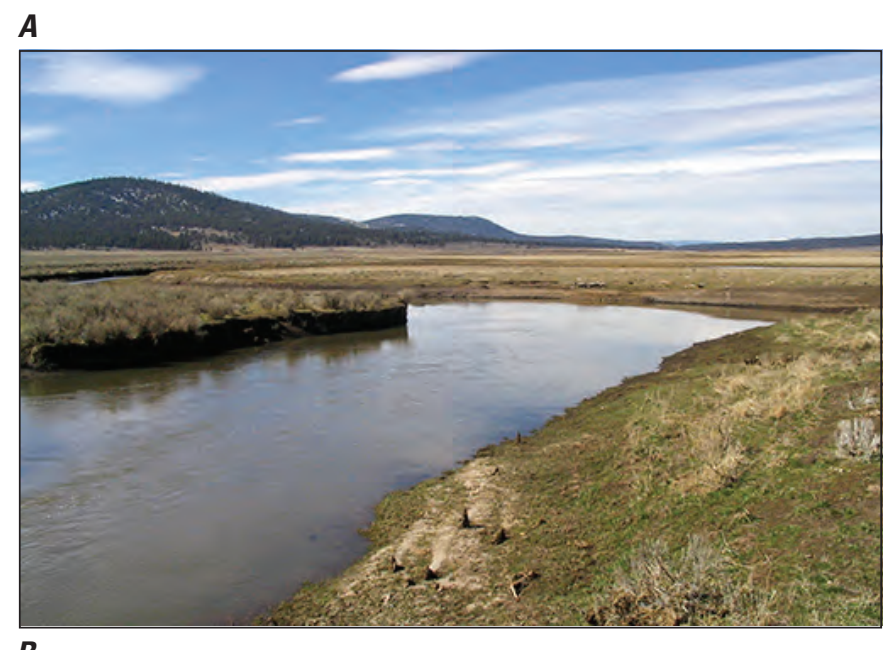

B

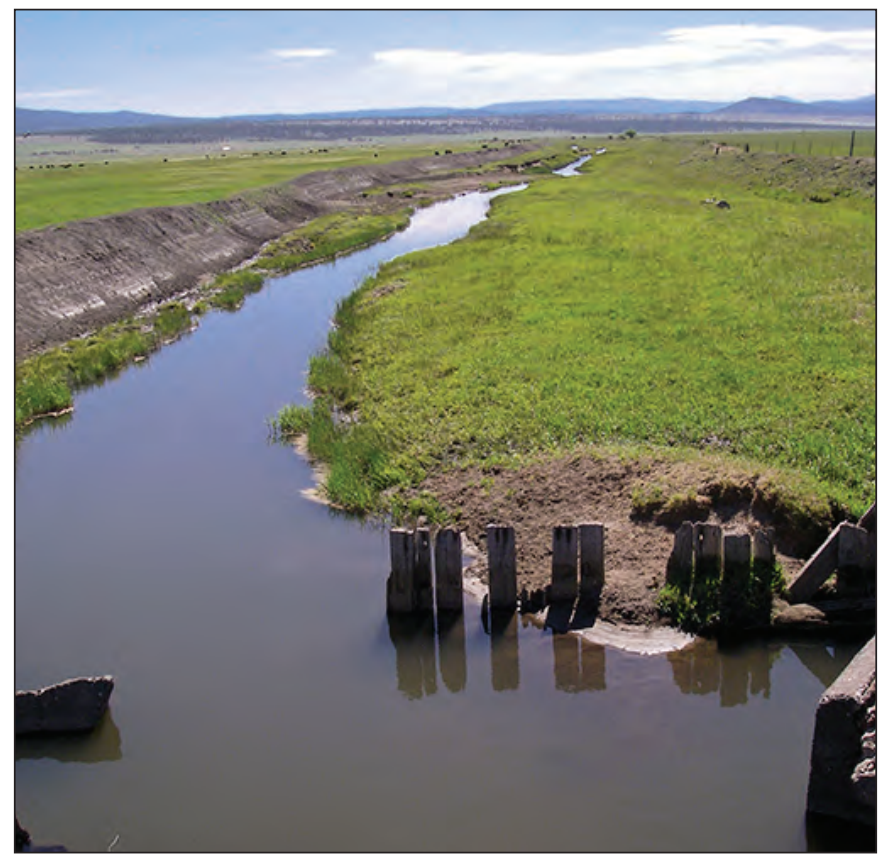

Figure 31. South Fork valley segment looking $(A)$ downstream from Ivory Pine Road bridge crossing at flood-plain kilometer (FK) 94.3 (March 9, 2004); and (B) upstream from diversion at FK 98.6 (June 20, 2007), Sprague River Basin, Oregon. Photographs taken by J.E. O'Connor, U.S. Geological Survey. 
abandoned tributary fans, tributary flood plains, and colluvial slopes, and by bedrock in upstream stretches. Fishhole Creek and Paradise Creek enter the flood plain from the south, and Deming Creek enters the flood plain from the north. Within this segment, the geomorphic flood plain is as wide as 2,500 $\mathrm{m}$ and averages $1,650 \mathrm{~m}$ in width, the widest of any valley segment in the study area (table 2 ; fig. 17). The channel only is locally close to the valley margin (fig. 16). The South Fork Sprague River is part of the geomorphically continuous east-west trending valley of the Sprague River; therefore, longitudinal plots in this report showing channel and flood-plain measurements join the main-stem and South Fork Sprague River measurements.

Average channel width for the South Fork valley segment is $10.5 \mathrm{~m}$, the narrowest of the study area, and the segment has a sinuosity of 1.17 , the lowest of any of the unconfined valley segments (table 2). The channel substrate has not been systematically evaluated, but at the upstream end of the reach it is cobbly sand and gravel. Downstream in the alluvial basin, substrate chiefly is indurated silt and clay with patchy sand and gravel. Channel slope averages 0.00100 for the entire segment, but decreases from 0.003 at the upstream end of the reach to about 0.0003 at the downstream end. The channel is interrupted by diversions at FKs 100.0 and 101.4, which both create 2-m steps in the longitudinal profile (fig. 32).

The flood plain of this valley segment has been the most modified of all segments in the study area. More than $200 \mathrm{~km}$ of ditches and levees constrain and divert the channel and overbank flow. Between FKs 93.2 and 101.6, the channel has levees on both sides, everywhere less than $100 \mathrm{~m}$ apart. The channel itself has been straightened, particularly between FKs 97.0 and 101.0 (fig. $31 B$ ). In these reaches, levee material likely was excavated from the channel. Much of the area of the geomorphic flood plain outside the leveed-channel area has been leveled and is lined with irrigation ditches. Two paved roads, Ivory Pines Road at FK 94.3 and Campbell Road at FK 101.4, as well as the railroad grade at FK 104.2, cross the flood plain and South Fork Sprague River. A private farm road bridges the river at FK 98.6.

The USGS measured streamflow on the South Fork Sprague River at the upstream end of the valley segment (near FK 106.2) during 1925-26 (USGS Oregon Water Science Center, Portland, Oregon, measurement records for station 11495500). More recently, Oregon Department of Water Resources has monitored flow near FK 98.6 (South Fork Sprague River downstream of Fishhole Creek near Bly; 11495600). Mean annual flow for WY 2010 (the only recent complete year of flow measurements) was $1.22 \mathrm{~m}^{3} / \mathrm{s}$.

\section{North Fork}

A single segment encompasses the alluvial portion of the North Fork Sprague River downstream from its emergence from the forested southwestern slopes of Gearhart Mountain.

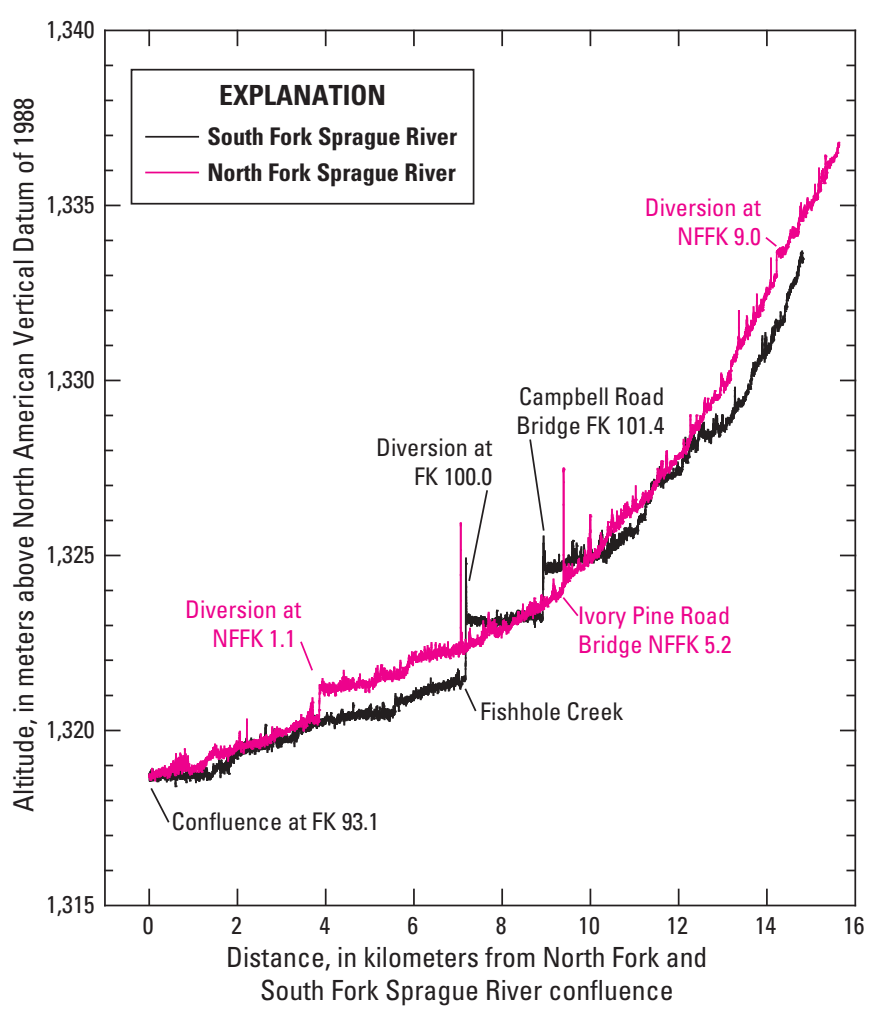

Figure 32. Approximate water-surface profiles from 1-meter spacing lidar data along 2004 channel centerlines, North Fork and South Fork Sprague Rivers, Oregon. Some of the high-frequency variability is from processing artifacts, but major discontinuities and slope changes represent actual channel conditions. FK, flood-plain kilometer; NFFK, north Fork Sprague River flood-plain kilometer. Locally, the channel margins are vegetated with sedges, rushes, and reed canarygrass. The flood plain is vegetated with grass (much of it irrigated), with dry parts growing sagebrush, rabbitbrush, and upland grasses. A few willows line the channel in the upstream part of the valley segment between FKs 104.0 and 106.3.

This valley segment includes $9.8 \mathrm{~km}$ of North Fork Sprague River flood plain outside the main-stem and South Fork Sprague River flood plain (thereby excluding the lower $1.9 \mathrm{~km}$ of the lower North Fork Sprague River channel). The North Fork Sprague River is joined by Meryl Creek at North Fork Sprague River flood-plain kilometer (NFFK) 4.8 and by Fivemile Creek at NFFK 1.7. The flood-plain width ranges from $90 \mathrm{~m}$ to nearly $1,200 \mathrm{~m}$ (average $530 \mathrm{~m}$ ), and is flanked by bedrock, colluvial slopes, and active tributary fans and flood plains.

The North Fork Sprague River winds through the North Fork valley segment with a sinuosity of 1.39 and an average width of $11 \mathrm{~m}$ (table 2). Channel slope averages 0.00124 , but it declines from 0.004 at the upstream end of the valley segment to 0.0004 near the South Fork Sprague River confluence. 
The channel substrate for the North Fork valley segment was not systematically investigated, but at NFFK 5.2, near the crossing of Ivory Pine Road, the channel has a cobblegravel bed, with some of the rock apparently placed to inhibit erosion. Farther downstream, at NFFK 3.7, the channel substrate is sand and gravel formed into pool-riffle sequences, and at NFFK 0.7, near the Campbell Road crossing, the bed is indurated silt and clay with patches of sand. A 1-m-high rock and timber diversion structure crosses the channel at NFFK 1.1 (fig. 32).

Low surfaces and bars near the channel are vegetated with rushes and sedges. Flood plains are vegetated with sagebrush, rabbitbrush, and grass. Some higher flood-plain surfaces are more than $3 \mathrm{~m}$ higher than the low-flow water surface and are densely vegetated with sagebrush and rabbitbrush (fig. 11). Sparse mature willows flank the channel near NFFK 2.1 and between NFFK 3.8 and 5.1.

For periods between 1917 and 1925, the USGS maintained a streamflow-gaging station at the upstream end of the reach near NFFK 9.4, but records are not sufficient to determine average annual flow (USGS Oregon Water Science Center, Portland, Oregon, measurement records for station 11496500, North Fork Sprague River near Bly). From various records, Gannett and others (2007) reported a total groundwater discharge to the North Fork Sprague River of $2.6 \mathrm{~m}^{3} / \mathrm{s}$, of which about $0.93 \mathrm{~m}^{3} / \mathrm{s}$ are contributed by springfed Meryl and Fivemile Creeks.

The North Fork valley segment also has many levees, diversions, and road crossings. Since at least 1904, as much as $0.7 \mathrm{~m}^{3} / \mathrm{s}$ of flow has been diverted from the North Fork Sprague River upstream of the study area to the South Fork valley segment by the Sprague River Irrigation Company (Kent, 1905; USGS Oregon Water Science Center, Portland, Oregon, measurement records for station 11496000). At least two local diversions also support nearby flood-plain irrigation (fig. 32). The channel is flanked locally by $8.9 \mathrm{~km}$ of levees, many of which protect areas of leveled and irrigated flood plain. Roads and bridges cross the flood plain and channel at NFFK $0.7,3.7$, and 5.4.

\section{Lower Sycan}

The Lower Sycan valley segment (fig. 33) encompasses the Sycan River valley bottom from near where it leaves Sycan Canyon to the Sycan River confluence with the Sprague River. This valley segment is $10.6 \mathrm{~km}$ long (table 2), not including the $0.75-\mathrm{km}$-long traverse across the Sprague River flood plain at the confluence of the Sycan and Sprague Rivers. Flood-plain width generally increases downstream, from less than $200 \mathrm{~m}$ near the downstream end of Sycan Canyon, to more than 1,000 $\mathrm{m}$ as the Sycan River flood plain joins the Sprague River flood plain. The Sycan River flood plain is adjacent to Sycan flood deposits for much of its length, but is locally also flanked by bedrock, active and abandoned tributary fan deposits, terraces, colluvial slopes, and spring deposits (figs. 7, 16). Snake Creek joins the Sycan River at Sycan River flood-plain kilometer (SYFK) 2.4.

The Sycan River channel averages $16.9 \mathrm{~m}$ wide, has a sinuosity of 1.38 , and is flanked by abundant bars, mainly composed of sand (table 2; figs. 17, 18, 33). Channel substrate ranges from mostly gravel at the upstream end of the reach to sand and gravel patches partly covering indurated silt and clay, probably Tertiary lacustrine sediment, at the lower end of the reach (fig. 34).

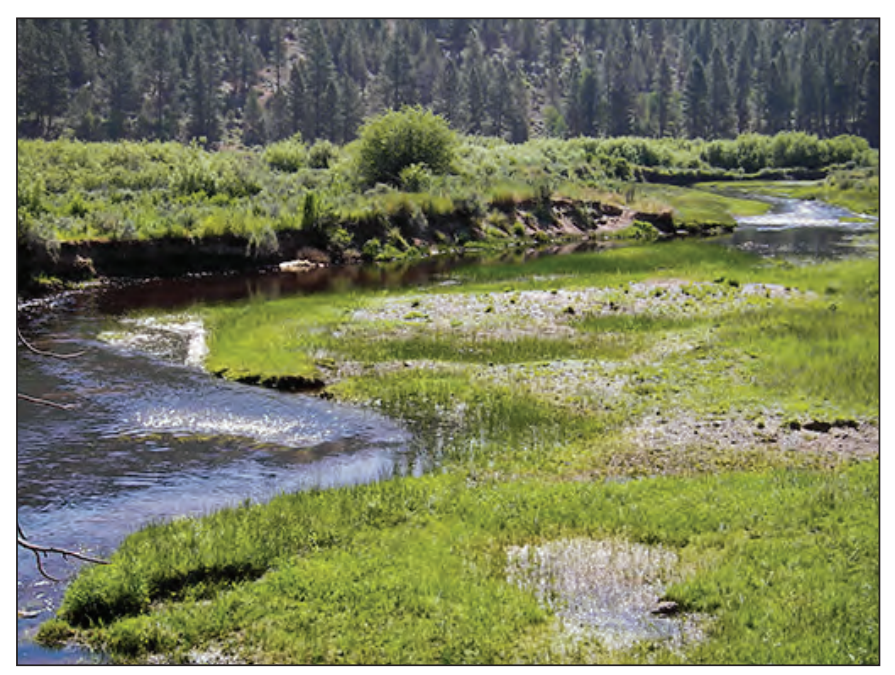

Figure 33. Lower Sycan valley segment looking downstream from Sycan River flood-plain kilometer 10.7, Sprague River Basin, Oregon. Photograph taken by J.E. O'Connor, U.S. Geological Survey, June 30, 2005.

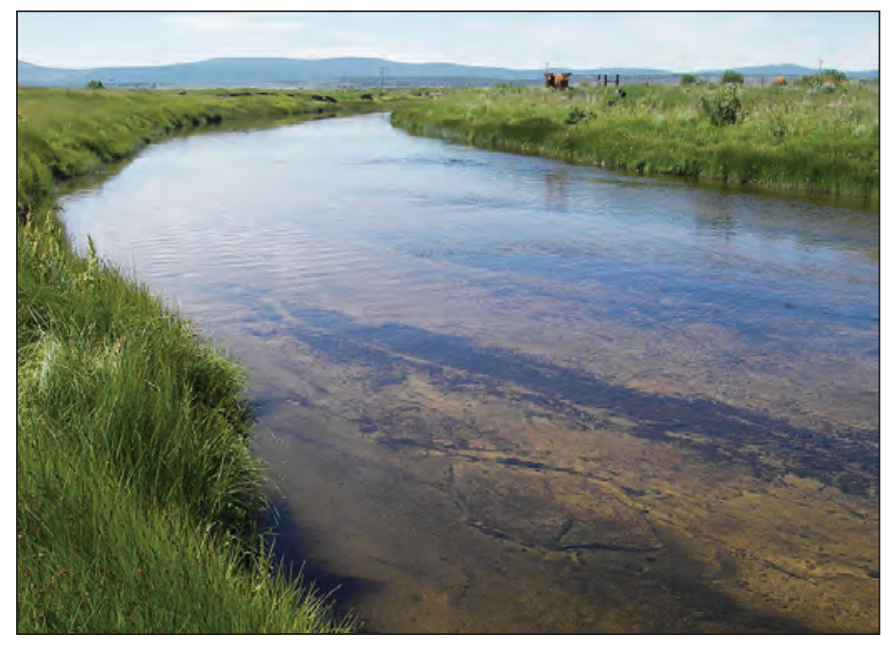

Figure 34. Sycan River flowing on Tertiary lacustrine sediment at Sycan River flood-plain kilometer 1.2 in the Lower Sycan valley segment, Sprague River Basin, Oregon. Photograph taken by J.E. O'Connor, U.S. Geological Survey, June 22, 2007. 
Channel margins and low flood-plain surfaces are locally vegetated with sedges and rushes, with abundant shrub cover (including willow, rose, and currant) along former channel paths (fig. 33) and taller stream banks. Higher flood-plain surfaces mainly are vegetated with sagebrush, rabbitbrush, and upland grasses.

Springs contribute flow by way of Snake Creek at SYFK 2.4, Brown Spring at SYFK 3.7, and many unnamed springs between SYFK 6.6 and 11.2. Total spring flow in this reach is about $0.14 \mathrm{~m}^{3} / \mathrm{s}$, contributing about 24 percent of the groundwater discharge (and total base flow) to the Sycan River downstream of Sycan Marsh (Gannett and others, 2007). Streamflow has been measured discontinuously on the Sycan River within this reach since 1912 (USGS Oregon Water Science Center, Portland, Oregon, measurement records for station 11499000, Sycan River near Beatty). For the OWRD streamflow-gaging station 11499100 at the Drews Road crossing at SYFK 2.2, mean annual flow for 1973-2010 was $4.22 \mathrm{~m}^{3} / \mathrm{s}$ (fig. 2).

The Lower Sycan valley segment has few ditches, levees, and roads on the active main-stem flood plain, totaling only $4.1 \mathrm{~km}$ (table 6). Spring diversions provide for water storage and irrigation. A few small areas of the flood plain have been leveled. The flood plain is crossed by Drews Road, which crosses the Sycan River at SYFK 2.2. The Sycan River channel abuts Godowa Springs Road at SYFK 0.3, where rip rap protects the road alignment from channel migration.

\section{Coyote Bucket}

The Coyote Bucket valley segment (fig. 35) includes $13.4 \mathrm{~km}$ of the Sycan River corridor through the lower and steepest part of the Sycan Canyon, from the downstream end of Teddy Powers Meadows at SYFK 24.0 to the downstream end of the canyon at SYFK 10.6. Because aerial photography and lidar coverage is limited to downstream of SYFK 15.4, mapping and analysis is complete only for the lower part of this valley segment. For the entire segment length, mean flood-plain width is $60 \mathrm{~m}$ (table 2); the narrowest of any segment in the study area, and is almost everywhere confined by bedrock or colluvium. The lower part of the segment, from near the confluence of Blue Creek at SYFK 13.4 to the downstream end of the canyon at SYFK 10.6, is narrowest and steepest, corresponding to where the river cuts through the Basalt of Knot Tableland. Two small rockfall landslides encroach upon the channel in this reach.

For the lowermost $4.6 \mathrm{~km}$ of this reach (the part within lidar coverage), average channel slope is 0.01794 , nearly 10 times steeper than the average channel slope of any other study reach (table 2). The channel bed is formed mostly of basalt boulders that have fallen from the canyon edges. The channel is confined largely by this coarse material, and sinuosity is a low 1.04. Four-wheel-drive tracks approach and parallel the river in a few locations, but otherwise this reach is unaffected by ditches, diversions, and levees.

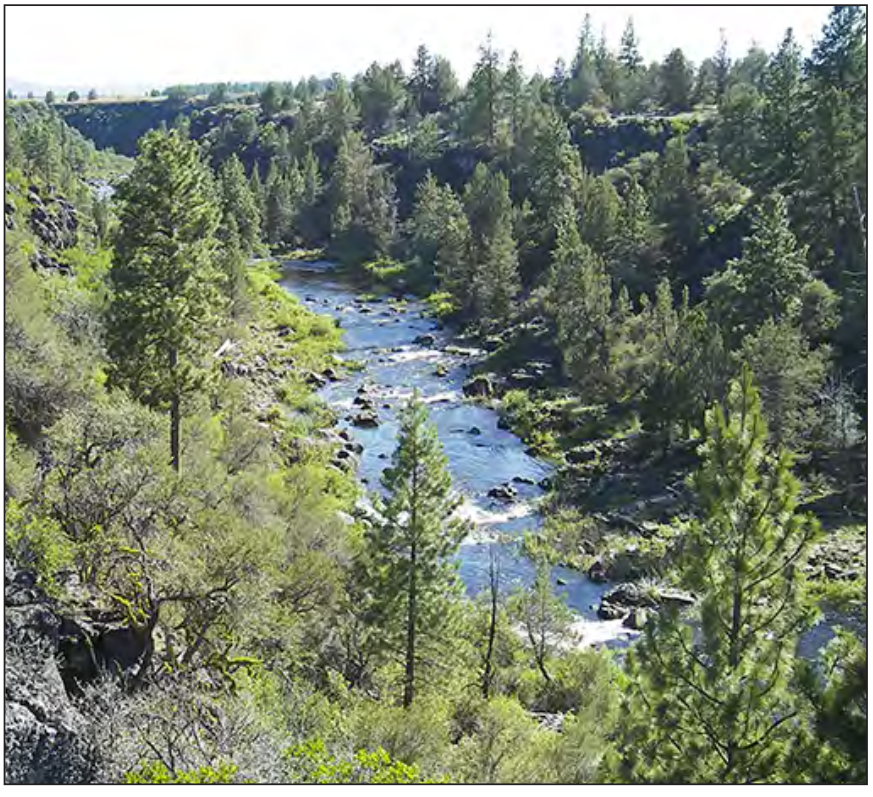

Figure 35. Coyote Bucket valley segment of the Sycan River looking downstream from near Sycan River flood-plain kilometer 13.2, Sprague River Basin, Oregon. Photograph taken by J.E. O'Connor, U.S. Geological Survey, June 24, 2006.

\section{Channel and Flood-Plain Conditions and Processes}

This section outlines key morphologic attributes of the Sprague River channel and flood plain, and how these attributes have changed at time scales encompassing the last century to the last several thousand years. These morphologic characteristics relate, in turn, to past and present processes of channel and flood-plain formation.

Historical data used in mapping and quantitative analysis of channel and flood-plain conditions mainly were from the cadastral surveys, aerial photographs, and lidar (table 4). Sediment transport measurements and a survey of effects of the 2006 high flow provide evidence of key processes presently affecting channels and flood plains. The augering transects and analysis of stratigraphic exposures (appendix C) provides information on flood-plain stratigraphy and channel position and processes over the last several thousand years, pre-dating substantial human flood-plain and channel alteration. Methods for analysis build upon previous studies of rivers in the Pacific Northwest, including the Queets and Quinault Rivers of western Washington (O'Connor and others, 2003c), the Deschutes River of central Oregon (O'Connor and others, 2003a), the Umatilla River of eastern Oregon (Hughes and others, 2006), and the Umpqua River of western Oregon (Wallick and others, 2011). 


\section{Historical Modification}

Much of the analysis of status and trends for the channels and flood plains of the Sprague and lower Sycan Rivers stems from maps, photographs, and observations from the $1860 \mathrm{~s}$ through 2010 (table 4). This period, however, coincides with the main period of human manipulation of the channel and flood plain for purposes such as agriculture, water supply and delivery, transportation infrastructure, flood protection, and channel and flood-plain habitat restoration. Therefore, analyses and observations are affected partly by these human-caused changes to the system, prompting this description of the major historical changes.

\section{Early Observations of Flood-Plain and Channel Conditions}

The earliest systematic descriptions of the study area were recorded in the maps and notes from General Land Office cadastral surveys (table 3 ). The maps and notes provide information on channel width and position as well as vegetation. Summary observations from the field notes accompanying GLO surveys have been transcribed onto modern USGS topographic quadrangles by the Oregon Institute of Technology and Shaw Historical Libraries (2011). These observations, spanning 1866-1892, typically describe the geomorphic flood plain of the wider valley segments as "land-level; soil-1st rate." Many of these wider flood plain areas also are described as "prairie." Unique among the wide flood-plain segments was the observation of extensive wetlands and marshes in the Upper Valley during the September 1866 survey of T36S-R14E. Here, several section corners between FK 96.9 and FK 94.3, just upstream of the North Fork confluence, were described in surveyor notes as "swampy." Wetlands also were shown on the corresponding plat map for parts of sections 16, 17, 20, 21, 22, 27, and 28. The GLO descriptions for the confined segments mainly note the rocky and forested terrains flanking the narrow flood plains.

These early GLO descriptions are in accord with subsequent maps and observations. A USGS land classification and timber survey encompassing the Klamath Quadrangle includes the study area downstream of FK 92 (Leiberg, 1903), showing most of the Sprague Valley as "non-forested as marshes, meadows and agricultural lands," and, near the town of Sprague River, "bottom lands, mostly grass covered, bordering Sprague River...” (p. 416). Similarly, a preliminary report on water resources for the Klamath Indian Reservation (Henshaw, 1912) and the field notes of botanist W.E. Lawrence summarizing observations in July 1922 and July 1934 (W.E. Lawrence, Oregon State University Herbarium, Corvallis, Oregon, unpublished field journals), show extensive and untimbered bottomlands flanking the Sprague River.
Early USGS records of streamflow measurements and related activities also provide information on channel and flow conditions and document the effects of diversions and log-driving activities on the Sprague River (U.S. Geological Survey, Oregon Water Science Center, Portland, Oregon, streamflow-gaging station records). In particular, channel conditions dating back to 1904, with extensive accounts for the period between 1912 and 1930, are contained in station notes and photographs for USGS streamflow measurement sites on the South Fork Sprague River near Bly, North Fork Sprague River near Bly, Fivemile Creek near Bly, Sprague River near Beatty, Sycan River near Beatty, and Sprague River near Chiloquin. Observations for the 1920s along the South Fork Sprague River (station 11495500) included accounts of "hardpacked gravel" substrate and that "willows may affect extremely high water." Likewise, for the North Fork Sprague River (station 11496500), station notes for May 18, 1925 report the "Channel very crooked near gage; no well [de]fined control...Willows on banks, left bank low..." Similarly at Fivemile Creek (station 11497000), “A crooked channel lined with a thick growth of alders was not conducive to a stable stage-discharge relationship for the site used 11 September 1917, to 11 May 1919...The pumice sand composition of the soil also contributed to constantly shifting conditions."

In the Beatty Gap area, 1912 reconnaissance notes by H. Kimble record that "The Sprague River from its forks near the eastern Indian Reservation line [near FK 93.0] westward to mouth of Sycan R. flows in a very deep channel and at very sluggish velocity and has many stagnant bychannels" (USGS Oregon Water Science Center, Portland, Oregon, streamflow-gaging station records; station 11497500, Sprague River near Beatty). Several early 20th-century accounts indicate mobile channel conditions and sand and gravel substrate for the Sycan River (Station IDs 11499000, 11499100), as well as measurements affected by thick late-summer aquatic growth.

For the Sprague River within the Kamkaun Spring reach, station records for streamflow-gaging station 11501000 , located at FK 28.6 between July 1920 and September 30, 1931, note that "Current sluggish everywhere; right bank well defined and high, left bank rather low, and some willows; bottom of hard pan overlain with pumice sand, probably shifting very slowly" (U.S. Geological Survey, Oregon Water Science Center, Portland, Oregon, streamflow-gaging station records). Additionally, records for this location summarize some of the alterations to the Sprague River associated with early European settlement that ultimately forced relocation of the station. These include construction of the OC\&E Railroad, the 1926 construction of a diversion dam $2 \mathrm{~km}$ downstream at FK 27.2, upstream diversion dams affecting flow as early as 1920, sudden flow fluctuations caused by operation of upstream regulating dams, and frequent log drives (fig. 20) that apparently led to many log jams (USGS measurement station records for station 11501000). 
Evidence for changing beaver, otter, and muskrat population was noted by some of the early streamflow measurement station records as well as a 1943 wildlife resource report on the Klamath Reservation by A.W. Moore (unpub. wildlife resource report by 1943, U.S. Fish and Wildlife Service, in Klamath Indian Agency records, National Archives, written commun. from Larry Dunsmoor, The Klamath Tribe, 2006). Moore reported:

Otter at present are practically extinct on the Reservation although some are occasionally reported from the lower Williamson River. Reports are that at one time this animal was common to all of the area." and "The muskrat is a relatively recent addition to the Reservations fauna. Introduction was through the establishment of a muskrat farm on Crooked [C]reek, a few miles north of the Agency.

Regarding beaver, Moore reported:

Evidences are that at one time the Reservation was abundantly supplied with this animal. A thorough reconnaissance along the Sprague river from the Modoc Point diversion dam [Chiloquin Dam; FK 1.3] to the island, in Section 26 R. 8 E. Twp. 34 S., a distance of about 9 miles [near FK 21.8], showed 32 old colony sites with their canals extending, in places, 100 yards from the river's banks. At present but three beaver were along this area. One was a solitary migrant, while at Braymill, a pair had established themselves and seven slides existed.

In sum, these early observations indicate pre-Europeansettlement flood plains that typically were grass-covered in the wider valley segments but forested in the narrow valley segments. The South Fork valley segment was swampy, even in September, an observation consistent with the organic-rich soils evident in the stratigraphy at the section described at FK 98.5 (fig. 8). The Sprague River locally was multichanneled and composed of sand and gravel substrate thinly or patchily covering indurated silt and clay. Channels were at least locally flanked by willow and colonized by beaver and otter. The Sycan River within the Lower Sycan valley segment was sandy and mobile.

\section{Ditches, Dams, Levees, Field Leveling, and Roads}

Digging of diversion ditches and temporary dams along the Sprague River started as early as 1890 , soon after first European settlement (Helfrich, 1974). By 1904, $37 \mathrm{~km}$ of ditches were irrigating parts of the South Fork, North Fork, and Upper Valley segments (Kent, 1905). By 1920, $37.6 \mathrm{~km}^{2}$ of valley bottom were irrigated in the Sprague River Basin, mainly by ditches within the wider flood-plain parts of the study area (La Rue, 1922). Additionally, the 1916 construction of Chiloquin Dam at FK 1.3 enabled water diversion from the Sprague River to the Modoc Irrigation District.
Extensive ditch and dike networks control flow within wider flood-plain segments, particularly in the South Fork valley segment (table 6; fig. 36). By 1968, the South Fork valley segment had more than $120 \mathrm{~km}$ of ditches and nearly $60 \mathrm{~km}$ of levees partitioning, draining, and diverting flow along the $13.1 \mathrm{~km}$ length of flood plain. By 2000, total levee length exceeded $80 \mathrm{~km}$. No other valley segment has the same density of flow manipulation structures, but all the unconfined reaches have substantial lengths of ditches and levees. The length of ditches and levees has increased in most valley segments for most time periods, but most construction was between 1940 and 1968, a result of a U.S. Army Corps of Engineers channelization program in the 1950s (Rabe and Calonje, 2009, p. 2-7). Since 1968, the length of levees generally has increased, whereas total ditch length has remained the same.

Associated with the locally extensive ditch network are many small dams and diversions. Most of these structures are in the South Fork valley segment, where 110 structures were evident in 1968 aerial photographs (table 6). The North Fork, Lower Sycan, Council Butte and Buttes of the Gods valley segments all had at least 10 diversion structures in 2000. Several low dams were built across the Sprague River between 1916 and 1926 to facilitate water diversions and mill and log transport operations (USGS Oregon Water Science Center, Portland, Oregon, measurement station records for station 11501000). Remnants of these structures, chiefly pilings and dumped rock, are still visible at many former diversion locations along the river. With the 2008 removal of Chiloquin Dam, no structures currently span the main-stem Sprague River.

As with the length of dikes and levees, the total road length and developed area within the flood plain has increased in all segments between 1940 and 2000, with the exception of the Chiloquin Canyon and Beatty-Sycan segments (ig. 36). The increase in road length noted from aerial photograph mapping is in addition to earlier wagon and automobile roads, and railroads constructed in conjunction with first settlement and expanded timber harvest in the early 1900s. In particular, the raised bed of the railroad alignment locally limits flood-plain inundation.

Although not systematically measured or mapped, another evident flood-plain modification is leveling or smoothing (fig. 37). Such smoothing and leveling, facilitated in recent years by global-positioning-system-controlled land leveling systems, aims to improve efficiency of flood irrigation - the most common irrigation practice in the Sprague River Basin (U.S. Department of Agriculture, 2009). Leveled fields within the Sprague River geomorphic flood plain appear as areas of obscured channel and scrollbar topography, and typically are associated with dense and regular networks of irrigation ditches. Leveled areas are most common in the Upper Valley and South Fork valley segments, although it is likely that all unconfined segments have areas of field leveling. 

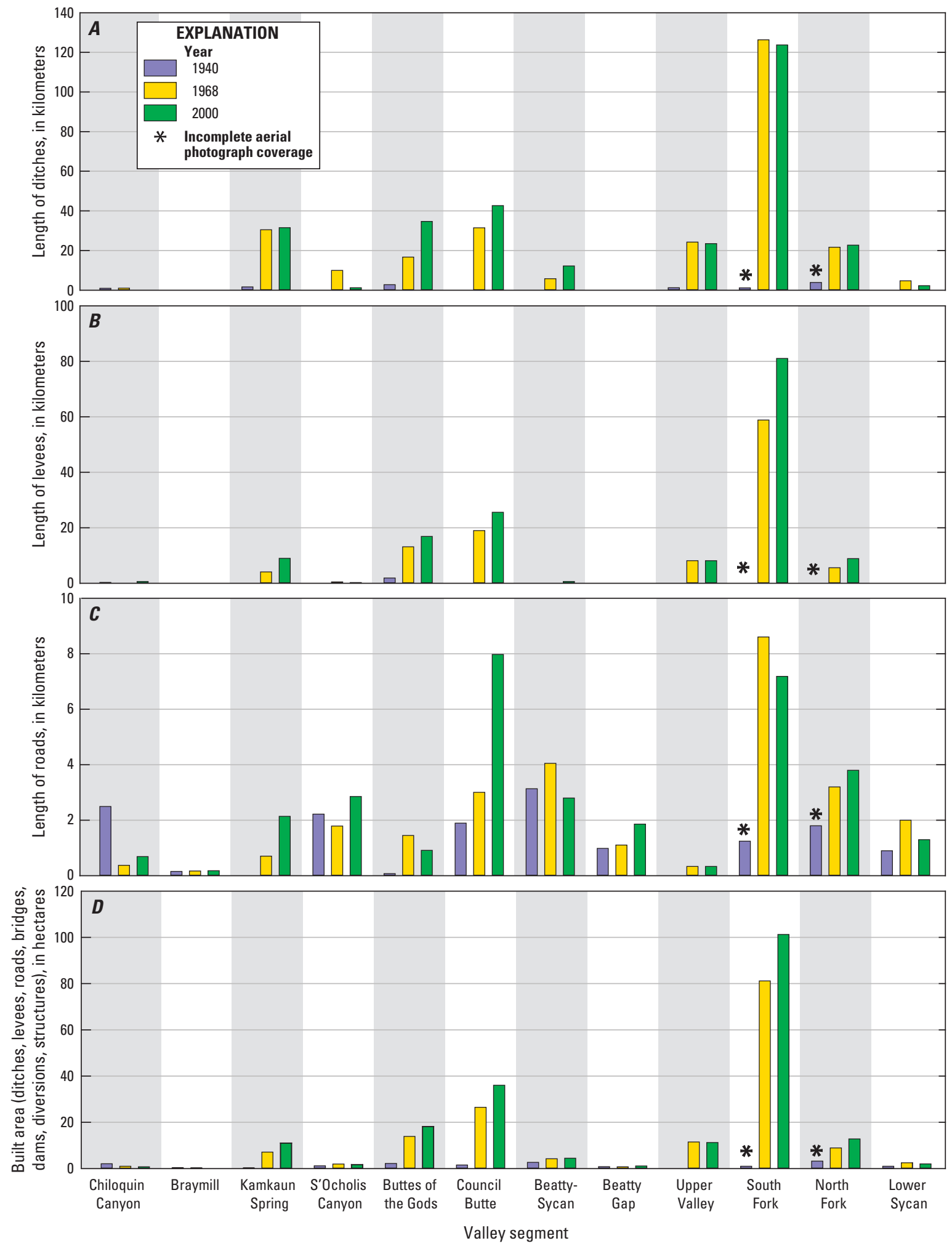

Figure 36. Extent of cultural features in the flood plain, including $(A)$ irrigation and drainage ditches; $(B)$ levees and dikes; $(C)$ roads; and $(D)$ total area covered by ditches, levees, roads, dams, diversions, and structures, as mapped from 1940, 1968, and 2000 aerial photographs, summed by valley segment, Sprague River Basin, Oregon. 


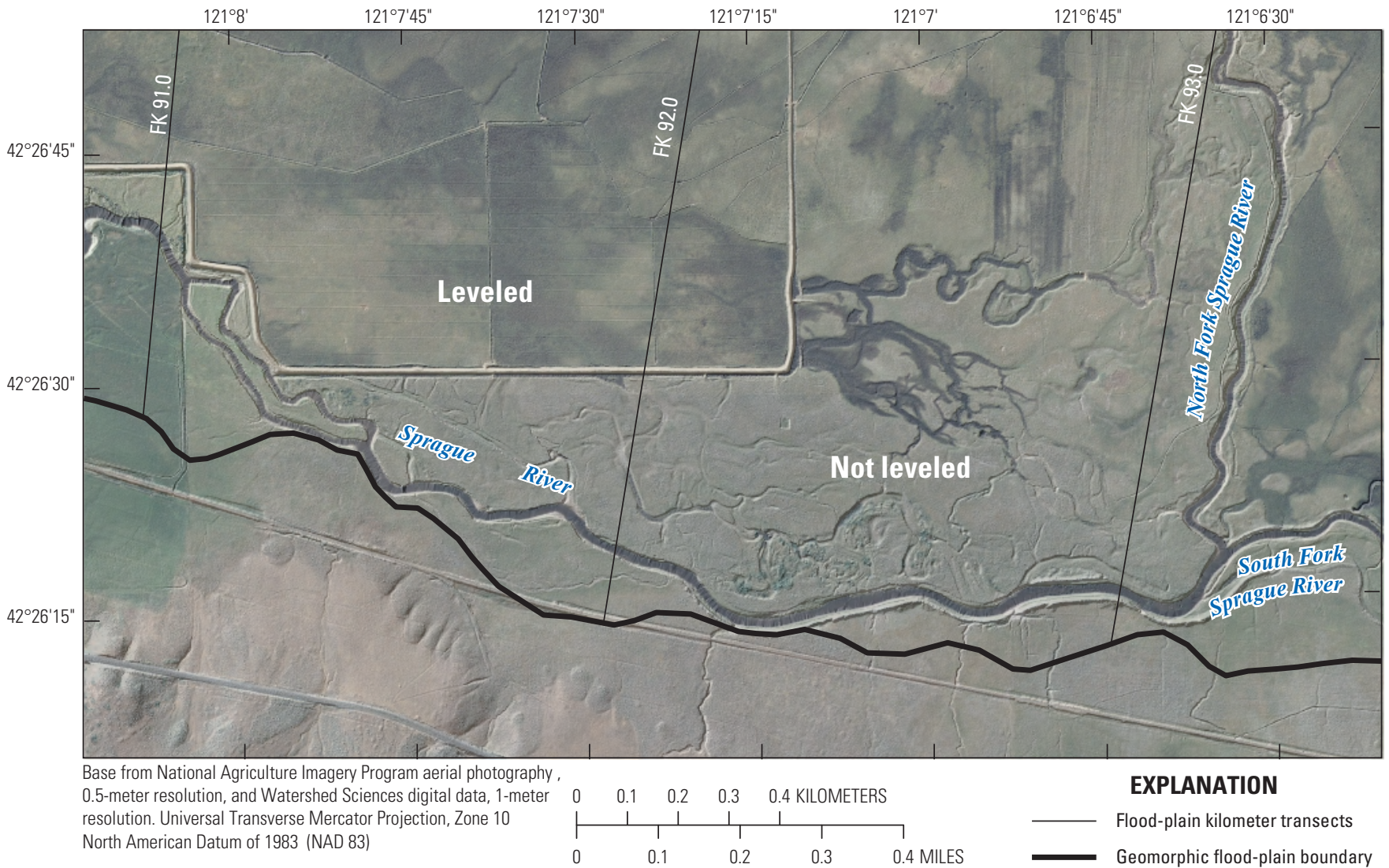

Figure 37. Flood-plain topography smoothed by field leveling between flood-plain kilometers 91.0 and 93.0, Upper Valley segment, just downstream of confluence of South Fork and North Fork Sprague Rivers, Sprague River Basin, Oregon.

\section{Channel Rehabilitation and Remeandering}

Since the 1990s, several channel restoration and rehabilitation projects have involved channel and flood-plain manipulation. These projects aim to improve aquatic and flood plain habitat conditions, and include activities such as riparian fencing, bank stabilization (with vegetation plantings and placement of rock and large wood), levee breaching, and channel manipulation. These activities generally date from the early 1990s, and most have been coordinated with the U.S. Fish and Wildlife Service. The most physically manipulative of these activities have been the channel plugs and remeandering, whereby the channel course is altered or moved by filling and excavating. In many cases, the channel is placed back in locations occupied prior to recent avulsions. In some instances, the new channel course is protected by rock and anchored logs placed along banks (fig. 23). At least five such projects were completed within the study area between 2004 and 2010, including sites in the Kamkaun Spring, Council Butte, Beatty-Sycan, North Fork, and Sycan valley segments (Sue Mattenberger, U.S. Fish and Wildlife Service, written commun., 2011).

\section{Channel Planform-Spatial and Temporal Trends}

Broadscale attributes of flood-plain and channel planform that are important geomorphically and ecologically include channel pattern, channel sinuosity, channel width, and the number and type of secondary channels. Important finer-scale attributes include bank morphology, bar area, bar frequency, and habitat measures such as pool frequency. The analyses in this study provide quantitative assessments of temporal changes for several of these channel and flood-plain attributes, drawing mainly from the historical maps and photographs.

\section{Channel Pattern}

Channel pattern characteristics such as sinuosity and frequency of secondary channels and backwater areas are important ecologically because they increase in-stream habitat complexity at all flow stages and provide refugia for fish and other aquatic organisms during high-flow stages (National Research Council 1992, 1996; Gregory and Bisson, 1997). 
Planform channel pattern varies from straight in confined reaches to highly sinuous in some of the unconfined valley segments (fig. 17). For the Kamkaun Spring, Buttes of the Gods, Council Butte, Beatty-Sycan, Beatty Gap, North Fork, and Lower Sycan valley segments, sinuosity approaches or exceeds 1.4. For the Chiloquin Canyon, Braymill, S'Ocholis Canyon, Coyote Bucket, and South Fork valley segments, sinuosity is less than 1.2 (fig. 38). The South Fork valley is unconfined, but the low sinuosity here owes to channel straightening and confinement by levees (fig. $31 B$ ), which, in turn, has resulted in a channel slope more than twice that of the adjacent downstream Upper Valley segment. For all unconfined reaches, sinuosity has decreased between 1940 and 2000 (fig. 38).

Within most of the study area, low flow is confined to a single channel. In total, secondary channels in which flow is conveyed during base-flow conditions occur along about 25 percent of the flood plain of the main-stem Sprague River and South Fork Sprague River (fig. 39). Few or no secondary channels convey flow in the Lower Sycan and North Fork valley segments. Most secondary channels are in the unconfined reaches, particularly the Kamkaun Spring and Council Butte valley segments, which have the lowest overall channel slopes.

The types of secondary channels present in the Sprague system include (1) short channels at the scale of a single meander, where a chute has developed across the meander core or neck but both chute and meander are still open and flowing; and (2) anabranches that are longer than a single meander (fig. 40). Such anabranches are distinct from channel braids in that they are separated from the main channel by vegetated and stable flood-plain surfaces rather than active bars. The degree of anabranching varies among segments in the Sprague River Basin, but they are particularly distinctive in the upper part of Council Butte valley segment and just downstream of the Sycan River confluence where they attain lengths of as much as $2.8 \mathrm{~km}$ and have been stable since 1940 (fig. 40C). The stability of these anabranches is consistent with the overall absence of temporal trends in the area of secondary channels between 1940 and 2000 (fig. 38).

Backwater areas, defined as side channels connected to the primary channel but without through-flow at low flow (sometimes termed blind channels), occupy about one-half of the total area of secondary channels (fig. 39). Their spatial distribution follows that of secondary channels, with 90 percent of the total backwater area in the unconfined Kamkaun Spring, Buttes of the Gods, and Council Butte valley segments. For these three valley segments, the total area of backwater has decreased by 32 percent between 1940 and 2000, although backwater area has increased since 1968 in the Council Butte valley segment (fig. 38).

\section{Channel Width}

Channel width is an ecologically important attribute affecting in-channel hydraulic conditions, flow conveyance, and stream temperature (by affecting exposure to solar radiation). Channel width may change through time by many causes, including human disturbance, land-use, and changes in hydrologic regime (Wolman, 1967; Hammer, 1972; Kauffman and Krueger, 1984; Simon, 1989; Trimble and Mendel, 1995; Simon and Rinaldi, 2006). Therefore, changes in stream width are commonly evaluated in fluvial assessments. Assessments of the upper and lower Sprague River Basin conducted by the Klamath Basin Environmental Foundation proposed that there has been historical stream incision and widening in some streams within the Sprague River basin, but that the extent of this disturbance is unknown (Connelly and Lyons, 2007; Rabe and Calonje, 2009). Similar observations and inferences throughout the Upper Klamath Basin have led to the regional management goal to decrease channel widths (Boyd and others, 2002).

Within the Sprague River study area, historical changes in channel width were assessed in two ways: (1) comparison of measurements during the GLO cadastral surveys of the late 1800 s with channel width as measured from the aerial photographs from 2000, and (2) measurement of changes since 1940 on the basis of channel mapping in this study from the sequential aerial photographs.

\section{Analysis of Channel Width from General Land Office Surveys}

The original GLO surveys in the Sprague River Basin date from 1865 to 1892 (table 3), corresponding to first European settlement but predating significant disturbance of the valley bottom and channel system. These surveys aimed to facilitate land parceling and distribution; consequently, information regarding the channel was incidental to these goals. Nevertheless, the notes and maps recorded by the surveyors as they measured the township grids and surveyed bank lines provide information on channel conditions and geometry. In general, channel width was noted in two ways: (1) for all surveys of the township boundaries and its subdivisions (1-mi square sections), surveyors indicated locations along section lines where they crossed water and the width (in the direction of the surveyed line) of the water body; (2) for the 1871-72 meander surveys within parts of the Chiloquin Canyon, Council Buttes, and Beatty-Sycan valley segments, bank lines were surveyed to better document river location and available acreage for homesteading and cultivation. The bank lines of these meander surveys were marked by posts or stones at intersections with section lines. 

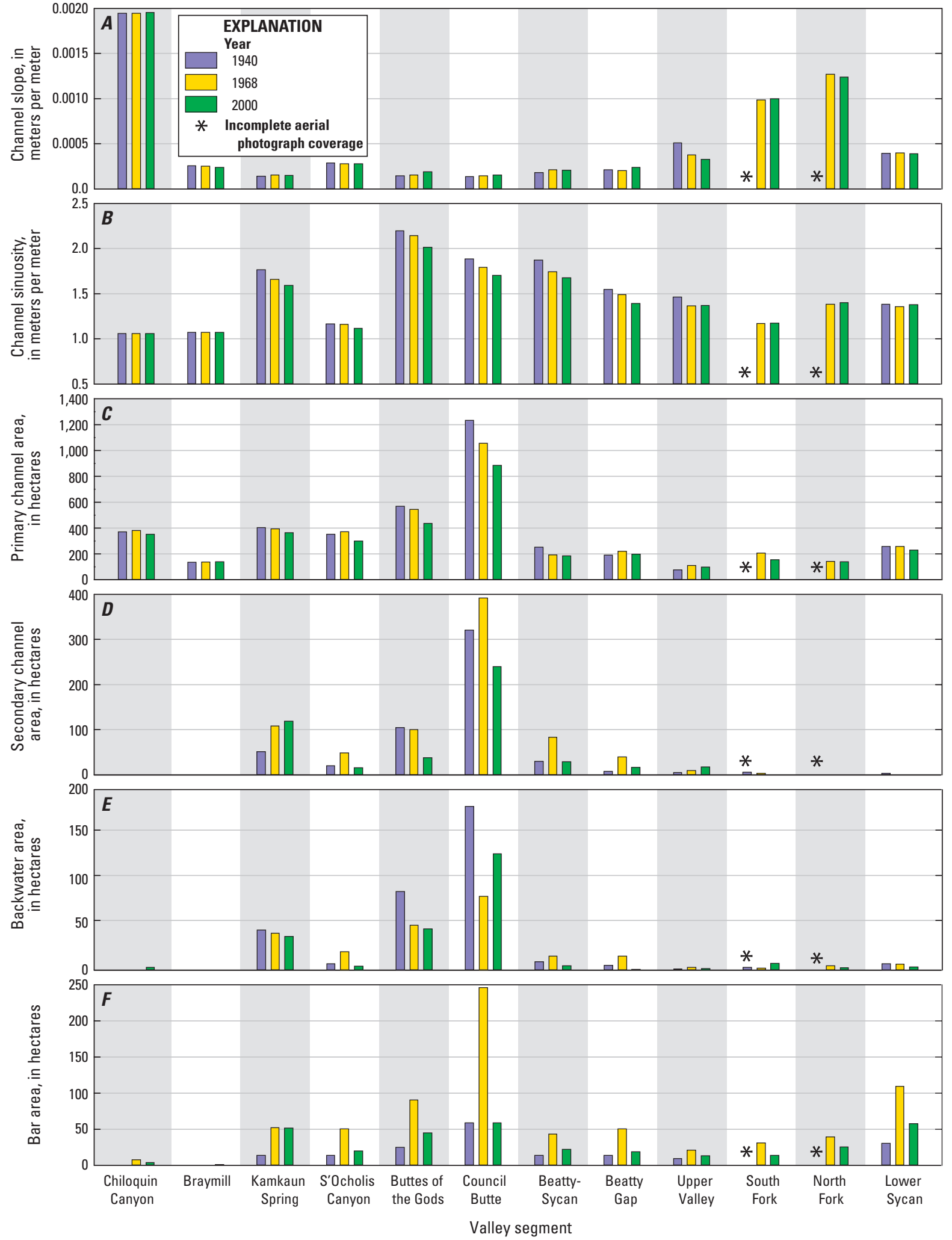

Figure 38. Summary plan-view channel and flood-plain characteristics, including $(A)$ channel slope, $(B)$ channel sinuosity, $(C)$ primary channel area, $(D)$ secondary channel area, $(E)$ backwater area, and (F) bar area, as mapped from 1940, 1968, and 2000 aerial photographs, summed by valley segment, Sprague River Basin, Oregon. 


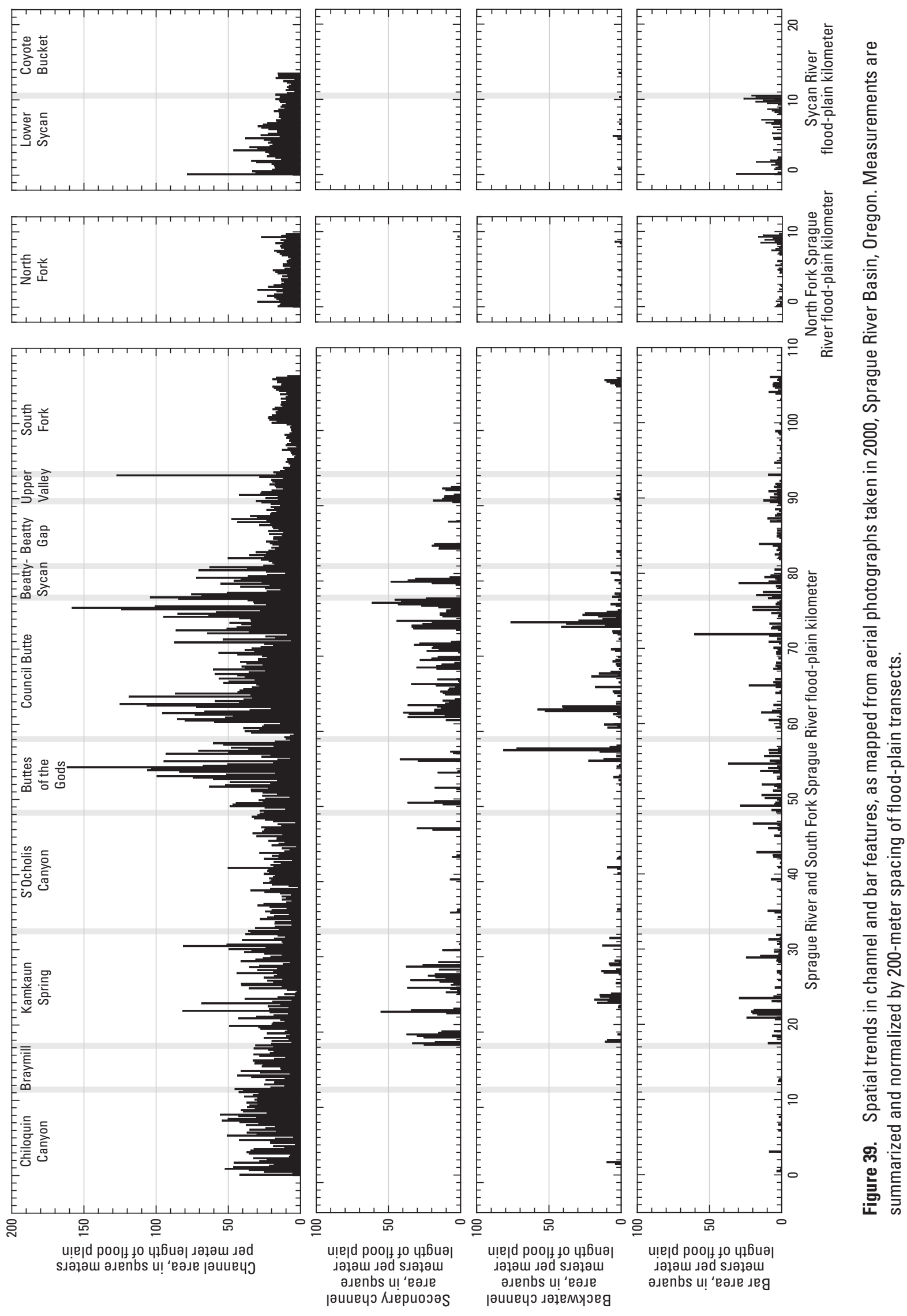


A

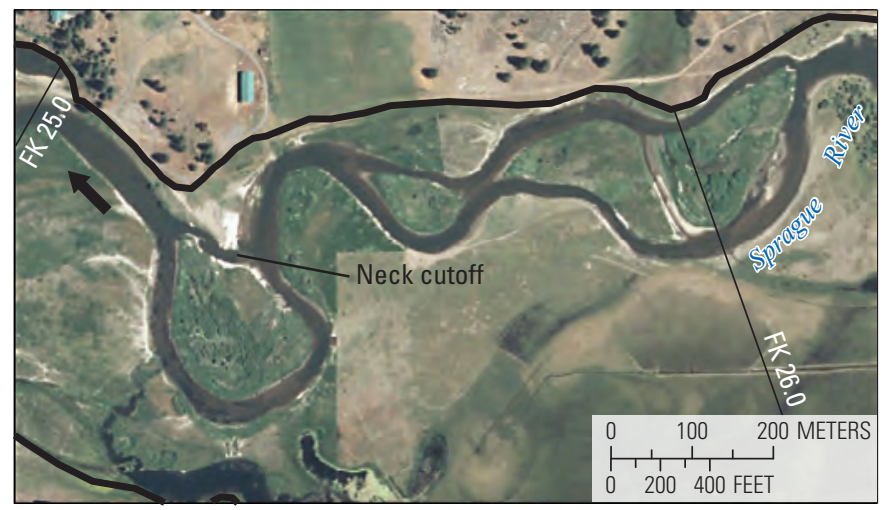

B

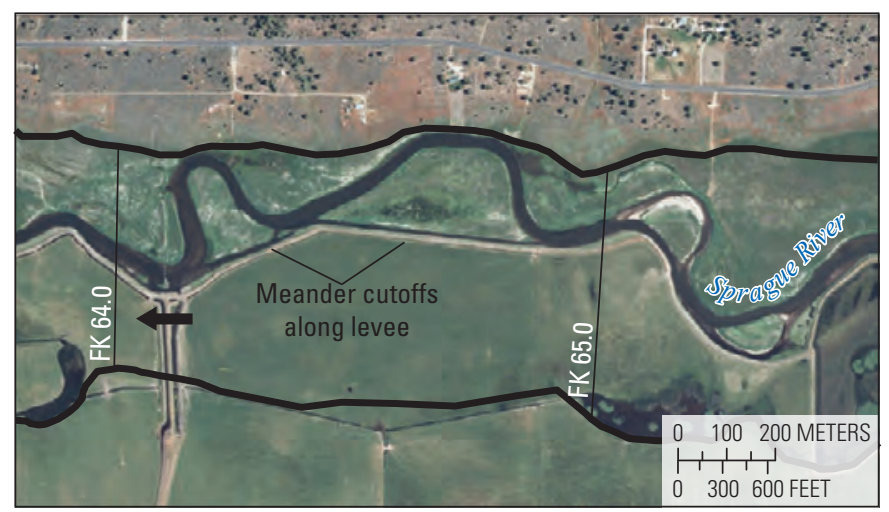

c

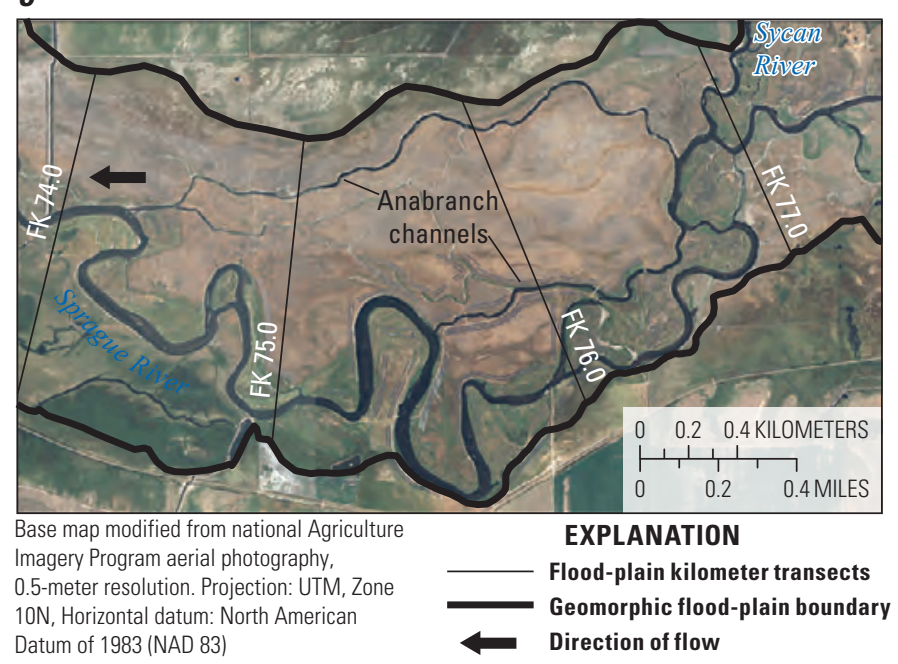

Figure 40. Examples of meander cutoffs, avulsions, and anabranches, including $(A)$ neck cutoff and avulsion between flood-plain kilometers (FKs) 25.0 and 26.0, Kamkaun Spring valley segment (the neck cutoff at FK 25.3 was filled in 2005-06, as shown in figure 23); $(B)$ meander cutoffs formed along levees between FKs 64.0 and 65.0 ; and $(C)$ anabranches spanning many meander loops between FKs 74.0 and 77.0, Sprague River Basin, Oregon.
In analyzing the river-width observations from the GLO surveys, an important uncertainty is the nature of the measured width - was it actual water width at the time of survey, or bank-to-bank width (similar to bankfull or active channel width)? In many situations, meander surveys can provide continuous channel-width information (for example, O'Connor and others, 2003c), but for the Sprague River, meander surveys were done for a limited section of the river, and only one bank was surveyed, so no actual measurements of river width can be obtained for these meander surveys except for where they were monumented at section-line intersections. The observations along section lines are more difficult to extract, requiring access to the surveyor notes, but may provide better information on actual channel width (Knox, 1977). The 1855 manual to GLO surveyors instructed surveyors to measure the widths of water features on the section lines, including "all creeks, rivers and smaller streams of water which the line crosses," with no mention of banks (White, 1983, p. 17), although practices varied from surveyor to surveyor and across time (Collins and others, 2003).

To clarify the distinction between the widths indicated by the meander surveys and those from the surveys along the section lines, we assessed the GLO surveys for three townships within the Council Butte segment, T36S R10E, T36S R11E, and T36S R12E. The section lines for these townships were surveyed in 1866 , at which time river width was measured along each section line as the surveyor crossed it. In July and August 1872, another surveyor returned to these townships to survey subdivisions of some sections (into 20 -acre lots) and to conduct a meander survey. Although only the south bank line was surveyed during this meander survey, surveyed monuments of both banks were placed at the intersections of the section lines, allowing direct comparison with the channel width as noted in the 1866 survey. This comparison shows that for 13 of the 17 section lines intersected by the meander survey, channel width noted in the 1866 section-line survey was less than the 1872 width from the meander survey, ranging from 22 to 94 percent (median value 67 percent) of the 1872 width (table 7). Of the four 1872 measurements showing a narrower channel width, two appear erroneous because the noted measurements do not close properly along the length of the section line (resulting in a negative calculated 1872 channel width). The other two measurements indicating a channel narrower by $10-15 \mathrm{~m}$ in 1872 also may represent survey error or possibly channel change in the 6 years between surveys. In sum, this comparison indicates narrower measurements associated with the section line crossings of 1866 relative to the meander surveys of 1872 , consistent with the inference that the meander surveys are of bank edges whereas the section line surveys denote actual water edges, as has been assumed in previous studies (Williams, 1971; Wallick and others, 2006). 
Table 7. Channel width measurements from General Land Office section-line and meander surveys, Sprague River Basin, Oregon.

[Chains, units for the General Land Office measurements were Gunter's chain, where 1 chain equals 20.1168 meters. Abbreviations: m, meter; T, Township; S, South; R, Range; E, East]

\begin{tabular}{|c|c|c|c|c|c|c|}
\hline $\begin{array}{l}\text { Township } \\
\text { and range }\end{array}$ & $\begin{array}{c}\text { Sections } \\
\text { separated by } \\
\text { surveyed line }\end{array}$ & $\begin{array}{c}1872 \text { distance } \\
\text { between } \\
\text { meander posts } \\
\text { (chains) }\end{array}$ & $\begin{array}{l}1866 \text { section- } \\
\text { line river width } \\
\text { (chains) }\end{array}$ & $\begin{array}{c}\text { Difference } \\
\text { between } 1872 \\
\text { and } 1866 \text { width } \\
\text { measurements } \\
\text { (chains) }\end{array}$ & $\begin{array}{c}\text { Difference } \\
\text { between } 1872 \\
\text { and } 1866 \text { width } \\
\text { measurements } \\
\text { (m) }\end{array}$ & $\begin{array}{l}\text { Channel } \\
\text { morphology }\end{array}$ \\
\hline T36S R10E & 10,11 & 2.25 & 2.00 & 0.25 & 5.03 & Straight section \\
\hline T36S R10E & 11,12 & 2.50 & 3.00 & -0.50 & -10.06 & Straight section \\
\hline T36S R10, 11E & 7,12 & 1.50 & 1.00 & 0.50 & 10.06 & Bend \\
\hline T36S R11E & 7,8 & 0.50 & 1.25 & -0.75 & -15.09 & Straight section \\
\hline T36S R11E & 8,9 & -1.00 & 1.00 & -2.00 & -40.23 & Slight bend \\
\hline T36S R11E & 9,10 & -1.50 & 3.00 & -4.50 & -90.53 & Bend \\
\hline T36S R11E & 10,11 & 3.75 & 2.50 & 1.25 & 25.15 & Bend \\
\hline T36S R11E & 11,12 & 1.50 & 1.25 & 0.25 & 5.03 & Bend \\
\hline T36S R11, 12E & 7,12 & 1.80 & 1.50 & 0.30 & 6.04 & Bend \\
\hline T36S R12E & 7,8 & 1.75 & 1.40 & 0.35 & 7.04 & Slight bend \\
\hline T36S R12E & 17,8 & 7.60 & 2.00 & 5.60 & 112.65 & Straight section \\
\hline T36S R12E & 17,16 & 3.50 & 2.00 & 1.50 & 30.18 & Bend \\
\hline T36S R12E & 16,15 & 3.50 & 2.50 & 1.00 & 20.12 & Bend \\
\hline T36S R12E & 15,10 & 3.75 & 1.50 & 2.25 & 45.26 & Bend \\
\hline T36S R12E & 10,11 & 4.50 & 1.00 & 3.50 & 70.41 & Straight section \\
\hline T36S R12E & 11,14 & 2.80 & 0.90 & 1.90 & 38.22 & Bend \\
\hline T36S R12E & 13,14 & 4.50 & 4.25 & 0.25 & 5.03 & Bend \\
\hline
\end{tabular}

Assuming that the section line surveys report measurements of actual wetted width, we assessed 143 section line crossings in the study area from the surveyors' notes, available from the Bureau of Land Management (2011). Because the section lines may cross the channel at various angles, the measured width was adjusted from available information on the channel orientation. For section lines where the river the survey notes indicate the channel crossing the section line perpendicularly, the GLO river width was not adjusted. However, for locations where the intersection between the channel and section line was not perpendicular, measurements of channel width along the section line were converted to width perpendicular to flow at the time of survey by multiplying the observed width by the sine of the angle between the direction of river flow and the surveyed section line. For most section lines, surveyors noted river flow direction only to the nearest cardinal or intercardinal direction, but for some sections it was recorded to the nearest degree. Additionally, for 16 section lines in the Council Butte and Beatty-Sycan valley segments, river flow directions were obtained from the plat maps showing 1872 meander surveys, assuming little change since the 1866 section-line survey.

Sixty of the 143 crossings were not fully analyzed because (1) they were highly oblique (greater than 60 degrees) to the channel direction, (2) they were at locations where comparison to modern channel widths would be challenging, such as at the apex of a meander bend or at a tributary confluence, or (3) no channel direction information was provided. Another 21 crossings were excluded because the GLO survey records of channel width and orientation were inconsistent with topography, indicating errors in the GLO survey notes.

Excluding the less reliable measurements, 62 late19th-century, channel-width measurements remained at known locations (appendix F). The spatial distribution of these measurements is uneven, ranging from only one observation along the combined length of the Chiloquin Canyon and Braymill valley segments, to 14 observations in the Council Butte valley segment. The resulting channel widths (perpendicular to flow) ranged from 6 to $58 \mathrm{~m}$, with many of the widest sections in the Kamkaun Spring and Council Butte valley segments. The narrowest channel widths were in the South Fork, North Fork, and Coyote Bucket valley segments. These GLO width measurements can be compared to the channel width measurements from the 2000 aerial photographs at the same locations. At the six sites where the 2000 aerial photographs showed bars flanking the channel at the section line crossing, the width of the bar was included in the channel width. All measurements from the 2000 aerial photographs were perpendicular to flow direction. Similar to the GLO measurements, measured channel width in 2000 ranged from 7 to $51 \mathrm{~m}$. 
Although the discharge at the time of the GLO surveys is unknown, the water widths in the GLO surveys and 2000 photographs likely are comparable because all widths were measured at relatively low flow. The 2000 aerial imagery was taken between late July and mid-August (table 4). The GLO surveys were between July and November, the five lowest flow months of the year based on long-term average discharge at Chiloquin (fig. 3).

Whereas different discharges associated with the surveys and measurements may introduce a small but unknown bias, more significant are transcription and survey errors that affect some of the observations, as apparent from the clear miscues noted in comparing the 1872 meander survey and 1866 GLO section-line surveys. An even more likely pervasive error results from adjusting the GLO measured channel widths to channel width perpendicular to flow direction. For locations where the angle of intersection was within 25 degrees of perpendicular, likely errors in the adjusted width are smallless than 10 percent. However, a plus-or-minus 25-degree uncertainty about a 45 degree intersection angle results in a plus-or-minus 30-percent uncertainty in the resulting adjusted width. For lower incidence angles, the resulting uncertainty is even greater.

The resulting 62 comparisons between channel width surveyed by the GLO between 1865 and 1892 (most were surveyed between 1865 and 1869) and those measured at the same location from 2000 aerial photographs show a wide range of change (appendix F; fig. 41). Although there are substantial discrepancies at some sites - in places the channel in 2000 is as much as four times as wide as it was at the GLO survey and in others it is less than one-half of its previous width - some overall trends are evident. In general, channels that were wide during the GLO surveys became narrower, and channels that were narrow became wider. The trend of the measurements crosses the 1-to-1 line between channel widths of 20 and $30 \mathrm{~m}$ (fig. 41A), indicating that this width range generally separates the channels that widened from those that narrowed. Overall, the median value of the ratio between the 2000 width and the GLO width is 0.96 , indicating slight overall narrowing of the measurement sites, but the difference is small relative to the variance and the measurement uncertainty.

Stratifying the observations by valley segments reveals trends within specific reaches (fig. $41 B$ ). The Kamkaun Spring and North Fork valley segments apparently have narrowed between the GLO surveys and year 2000, as possibly has the Beatty Gap valley segment with three of its four measurements showing narrowing. By contrast, four of the five comparisons in the South Fork valley segment indicate widening. Overall widening trends also are possible in the Council Butte, Beatty-Sycan and Coyote Bucket valley segments, although data are either few or the differences are small.
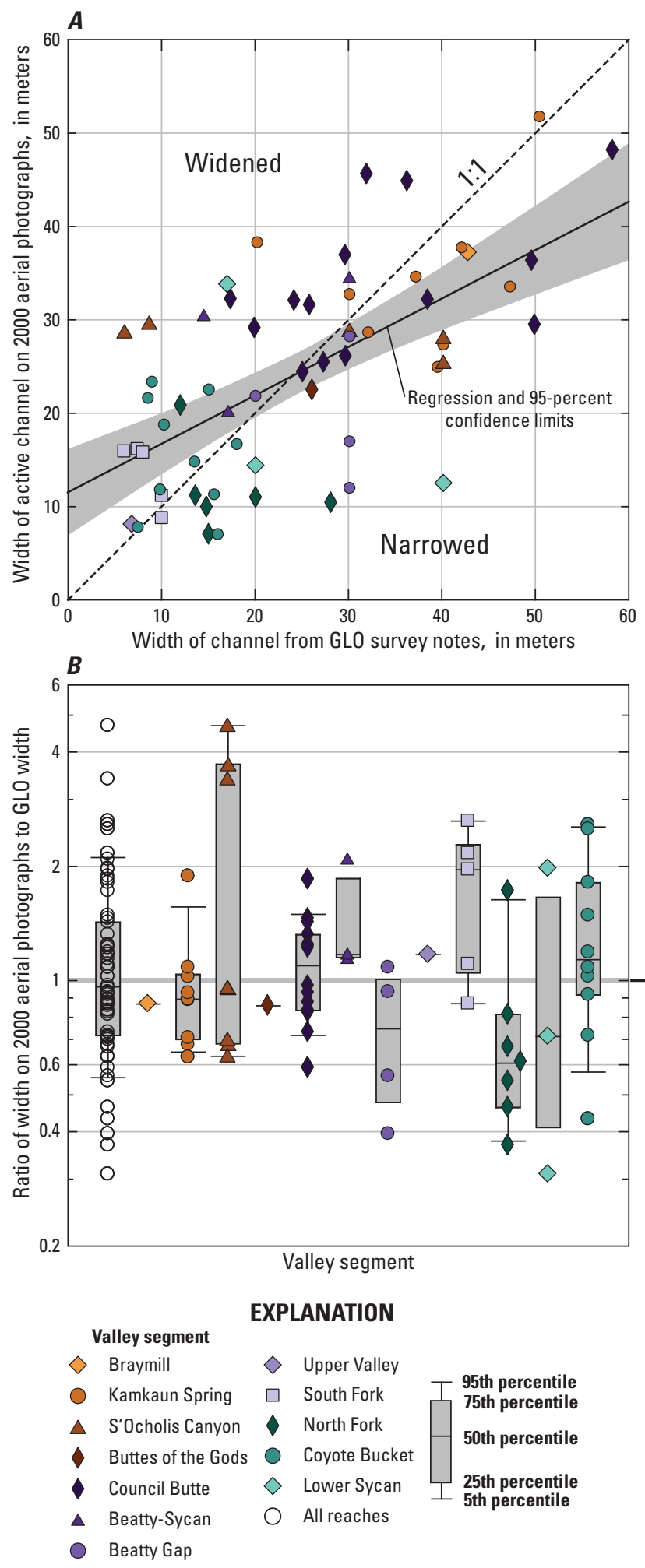

Figure 41. General Land Office (GLO) surveyed (chiefly in 1866) widths compared with measured widths from aerial photographs taken in 2000 for $(A) 62$ GLO surveyed widths and at the same location as determined from aerial photographs (table 7); and $(B)$ relation between $\mathrm{GLO}$ and widths in 2000 by valley segment, Sprague River Basin, Oregon. 


\section{Analysis of Channel Width from Aerial Photographs}

Observations of channel width derived from historical aerial photographs are more systematic but cover a shorter period than those derived from GLO surveys. For this analysis, channel widths for each of the 1940, 1968, and 2000 photographic sets were measured on transects spaced $200 \mathrm{~m}$ apart along the channel centerline. For these measurements, the wetted width orthogonal to the channel centerline was considered the channel width. Because the channel centerline shifted between years, transect locations are not identical for each period. However, the large number of observations - for example, 932 width measurements within the study area from the 1968 aerial photographs - permits observation of general trends in channel width both spatially and temporally (figs. 42, $\underline{43}$ ).

Overall, the median primary channel width for 682 measurements along the main-stem Sprague River in 2000 was 30.3 m. For the North Fork Sprague River, the median channel width (for 79 measurements) was $10.0 \mathrm{~m}$; for the South Fork Sprague River (74 measurements), the median channel width was $9.3 \mathrm{~m}$; and for the Sycan River along both the Lower Sycan and Coyote Bucket segments (152 measurements), the median channel width was $14.1 \mathrm{~m}$. For all time periods, the channel generally is widest in the unconfined segments, particularly the Buttes of the Gods, Council Butte (where width locally exceeds $100 \mathrm{~m}$ ), and Beatty-Sycan segments. The channel also is wide in parts of the Kamkaun Spring segment as well as in the lower part of the Chiloquin Canyon segment near the Sprague River confluence with the Williamson River and where the channel was impounded by Chiloquin Dam at FK 1.3.

The channel generally was widest in the 1968 aerial photographs, when the median width of the main-stem Sprague River was $32.4 \mathrm{~m}$ compared to $29.9 \mathrm{~m}$ in 1940 and 30.3 in 2000. This was the case for most individual valley segments as well (fig. 43); of the valley segments with complete aerial photograph coverage for all three years, only the Braymill and Council Butte valley segments had wider channels in either 1940 or 2000. For six segments (Kamkaun Spring, S'Ocholis Canyon, Buttes of the Gods, Beatty-Sycan, Beatty Gap, and Upper Valley), widening was substantial - as much as 60 percent of the 1940 width in the case of Upper Valley. Between 1968 and 2000, most segments narrowed to widths similar to those measured from the 1940 photographs. For some valley segments, such as Lower Sycan and BeattySycan, narrowing decreased median channel width by as much as 20 percent. The Council Butte valley segment is unique in having an apparent systematic decreasing trend in median width between 1940 and 2000 (fig. 43). The South Fork valley segment shows a similar trend, but the 1940 aerial photograph coverage is incomplete for this segment. The variance in channel width has decreased since 1940 for several valley segments, particularly upstream of S'Ocholis Canyon (fig. 43).

\section{Bars}

Bars are significant fluvial features because they are indicative of bedload transport and contribute to physical habitat complexity. Active sand and gravel bars are relatively sparse for much of the Sprague River and its major tributaries (fig. 39). Total bar area in the study area at the time of the 2000 aerial photographs was about $330,000 \mathrm{~m}^{2}(33.0$ hectares [ha]), less than 10 percent of the corresponding primary channel area. Bars are distributed more broadly than secondary and backwater channels, with a few bars flanking the channel in all valley segments (fig. 18). Bars generally are more common and larger in the unconfined reaches than in confined reaches, although the confined Beatty Gap and $S^{\prime}$ Ocholis Canyon valley segments have abundant bars. Bars are sparse in the narrowly confined Chiloquin Canyon and Braymill valley segments.

Bars are locally abundant where the North Fork Sprague River and Sycan River leave steeper and more confined segments. For the North Fork Sprague River, this corresponds to the upper end of the study reach where the North Fork emerges from Fremont National Forest. For the Sycan River, bars are most abundant where the river leaves the steep and confined Coyote Bucket valley segment (figs. 18, 39). Similarly, many of the few small bars in the South Fork valley segment are at the upstream end of the study area, where the river emerges from the foothills east of Bly. Bars also are concentrated near the Sycan River confluence with the Sprague River within the Council Butte and Beatty-Sycan valley segments.

In nearly all valley segments, bar area was greater in 2000 than it was in 1940, with the total area (excluding the North Fork and South Fork valley segments for which the 1940 photographs are incomplete) increasing from 18 to 29 ha (fig. 38). It is not clear, however, that this is a longterm trend because the area of bars was much larger in 1968 (when bar area totaled $67 \mathrm{ha}$ ) than in 2000. This large 1968 total almost certainly owes to enhanced sediment transport and bar formation and expansion during the $422 \mathrm{~m}^{3} / \mathrm{s}$ flow of December 26, 1964, the largest flood since at least 1920 (fig. 2).

\section{Channel Migration}

Closely related to processes affecting channel planform are those that control the rates and styles of lateral channel migration. For the Sprague River study area, the stratigraphic analyses and the analyses of sequential photographs together document the relative importance of processes such as lateral migration, meander cutoffs, and avulsions in controlling the overall channel pattern and rates of evolution. 

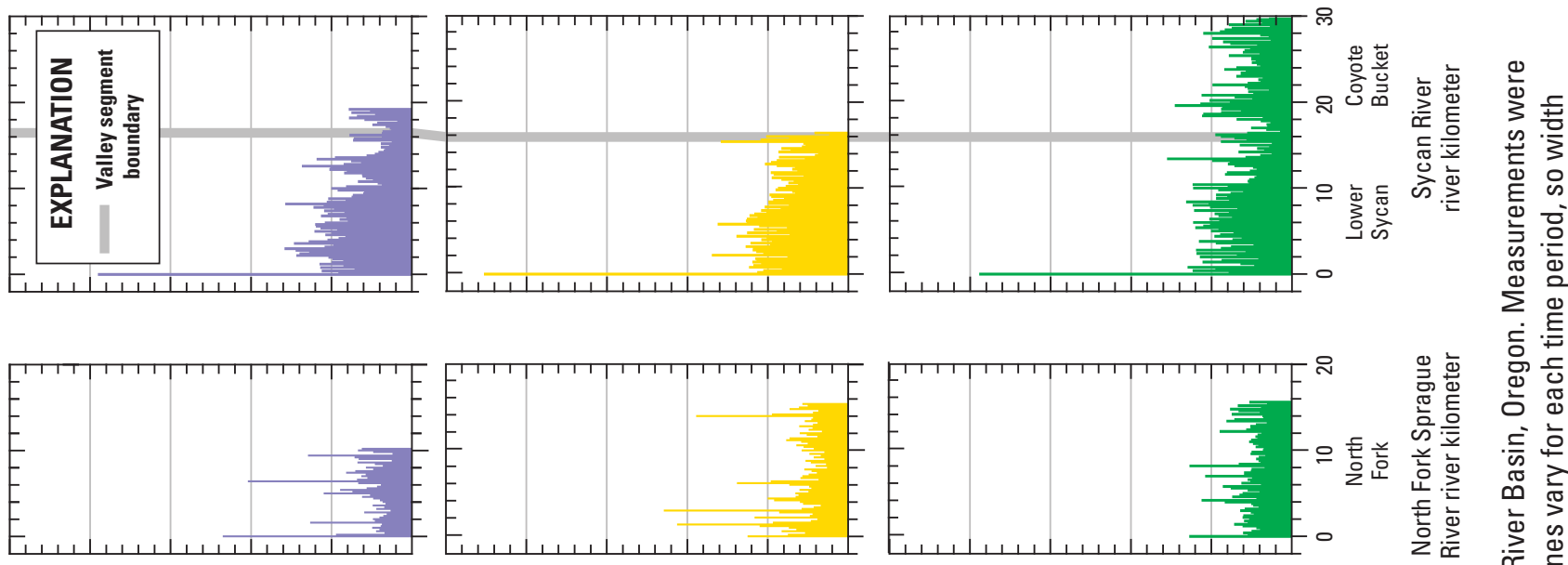

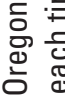

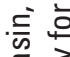

苑

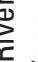

,

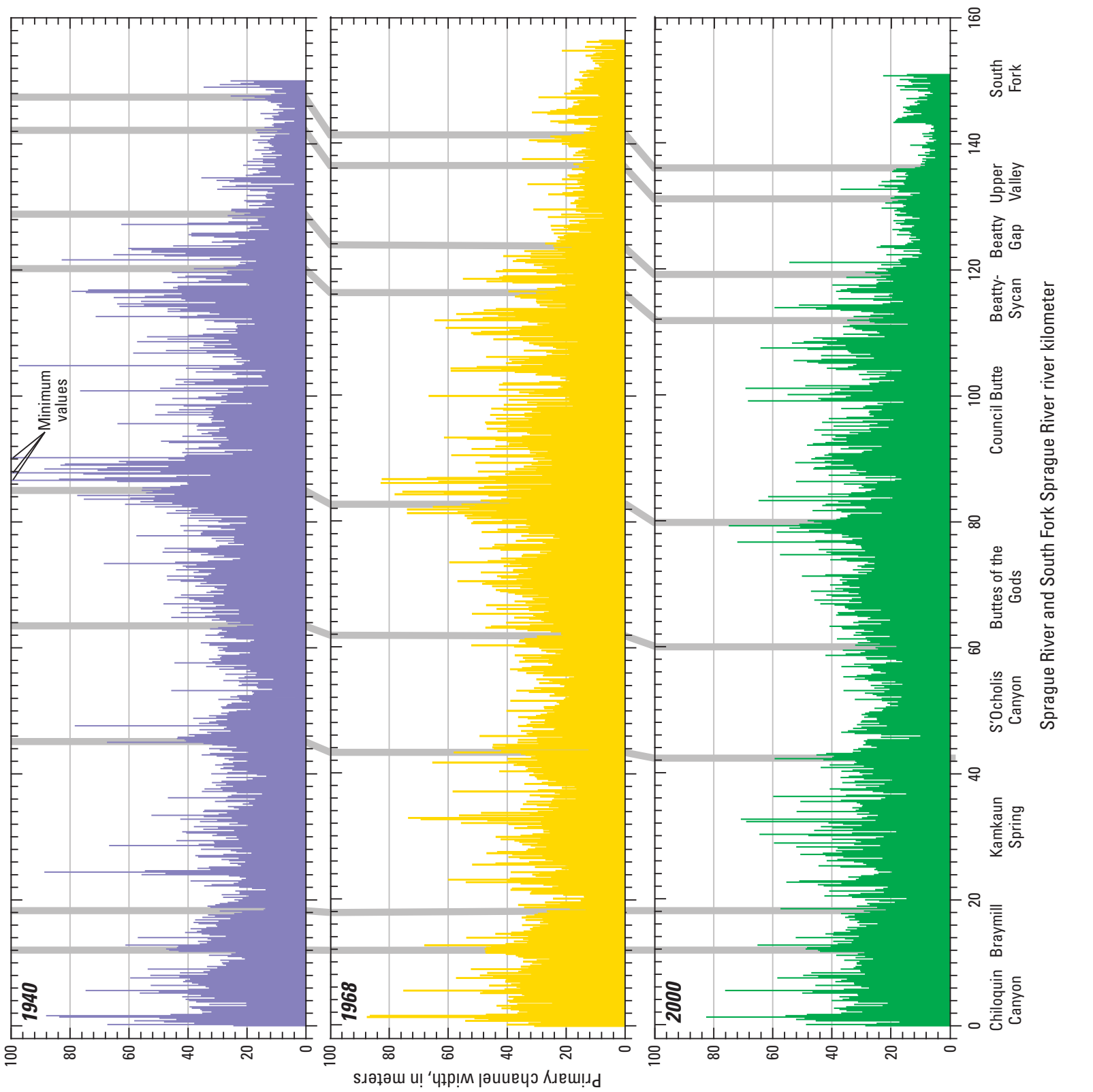

売

흔

융

은

क

흠

守

듬

헣 들

등을

ธัँّ

옹

등 융

즌 능

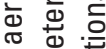

E E त

은 융으

Ф)

응흔

造 क

赵

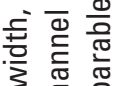

3 증 을

은 언

든 흠

등 음 원

등 ㄴ.

닌 응

뜰 힌

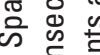

ชั

元

흠 吾 


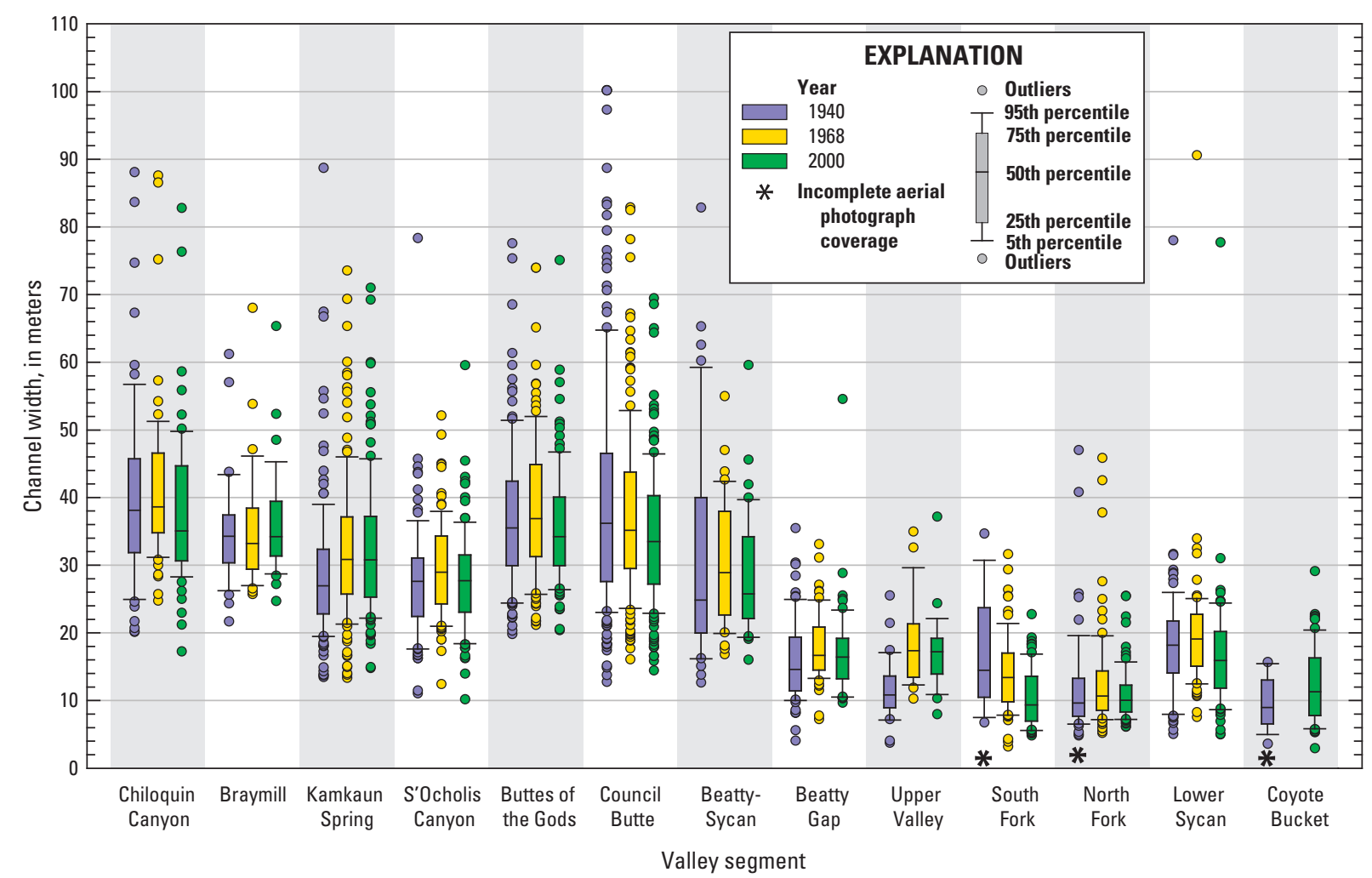

Figure 43. Wetted channel width measurements summarized by valley segment, Sprague River Basin, Oregon. Because of aerial photograph coverage limits, the 1940 measurements include only small parts of the South Fork, North Fork, and Coyote Bucket valley segments; no 1968 measurements are available for the Coyote Bucket valley segment. Channel widths are shown in figure 42.

\section{Observations from Stratigraphy and Morphology}

The stratigraphic exposures, augering transects, and surficial morphology indicate lateral bar growth and channel migration, followed in many instances by channel abandonment, presumably by meander cutoff or avulsion. Lateral flood-plain building is evident from the dipping beds visible in stratigraphic exposures along the North Fork Sprague River (figs. 9, 11) and Sycan River (fig. 14). The scroll-bar morphology locally evident on low and young flood-plain surfaces (fig. 13) indicates lateral channel migration in conjunction with sandy point bar development, an observation consistent with point bar deposition during the 2006 high flows (fig. 15).

Many of the meander bends, however, appear to have been abandoned rapidly, leaving distinct and isolated oxbows or swales. The stratigraphy of deposits filling these former channels shows abrupt transitions, with basal bedrock strath surfaces, gravel, and sand associated with active channel environments overlain by peat, silt, and clay (figs. 12, 13). At some sites, such as 9/22/05-4 at FK 48.7 (fig. 12), where the paleochannel is substantially filled with sand and gravel, meander cutoff or channel avulsion may have been promoted by point-bar growth blocking sharp bends. Prehistoric avulsions, particularly in the more densely timbered confined reaches, may have been triggered by log jams.

Channel migration only slowly works its way across the flood plain, as also is evident from the stratigraphic analyses. Some of the preserved paleochannels are nearly 4,000 years old (fig. 12), and many flood-plain sections have been accumulating overbank deposits for several hundreds of years and, in places, thousands of years subsequent to the last channel occupancy (ㅁigs. $5, \underline{8}, \underline{9}$ ). 


\section{Centerline Analysis}

Rates of channel migration can be derived from the historical maps and photographs, although rates and mechanisms observed since the first maps of the 1860s and the photographs beginning with 1940 likely have been affected by land use and channel manipulation. Channel migration was measured in the manner of O'Connor and others (2003c), in which the channel centerline position for each time period was evaluated in reference to flood-plain transects spaced $200 \mathrm{~m}$ apart along the flood-plain centerline. The change in position of the intercept between successive channel centerlines and the flood-plain transects indicates the net lateral movement with respect to the flood-plain reference system. This net movement divided by the time period between mapped positions gives an average annual migration rate. Centerlines were mapped for the meandered sections of the GLO maps in the Council Butte and Beatty-Sycan valley segments, as well as from the 1940, 1968, 1975, 2000, and 2005 aerial photograph and map sources (table 4). Parts of the South Fork, North Fork, Lower Sycan, and Coyote Bucket valley segments are incompletely covered by the 1940 or 1975 photographs and maps; consequently, migration rates encompassing those time periods and segments are incomplete.

Calculated migration rates for various periods between about 1870 and 2005 mostly are less than $0.5 \mathrm{~m} / \mathrm{yr}$ but are as much as $30 \mathrm{~m} / \mathrm{yr}$ (figs. 44, 45). Migration rates vary spatially and temporally, with the overall greatest migration rates in the unconfined valley segments, particularly the Kamkaun Spring, Buttes of the Gods, and Council Butte valley segments. The unconfined South Fork valley segment is an exception, with low migration rates (particularly since 1975) similar to those measured for the Chiloquin, Braymill, and S'Ocholis Canyon valley segments.

Migration rates are spatially and temporally correlated; reaches of high and low mobility tend to extend for several kilometers and to persist for many measurement periods (fig. 44). Additionally, some reaches for some periods have exceptional migration rates exceeding $5 \mathrm{~m} / \mathrm{yr}$. These very high rates owe to the channel moving large distances laterally by translocation across the flood plain rather than by continuous migration from lateral bank erosion and point bar development. In most cases where migration rates exceeded $1 \mathrm{~m} / \mathrm{yr}$, avulsion or meander cutoff was responsible. The median migration rates, ranging from about 0.06 to $0.3 \mathrm{~m} / \mathrm{yr}$ for most segments (ig. 45 ), probably represent rates of continuous lateral shifting by bank erosion.

For most valley segments, the 1968-1975 period had the highest migration rates (fig. 45). However, this period appears unique within an overall declining trend of historical migration rates, with the 2000-2005 period having the lowest median migration rate for 10 of the 13 analyzed valley segments. This declining trend is evident particularly for the Council Butte and Beatty-Sycan valley segments, for which migration rates were calculated dating back to the 1870 s GLO meander maps.

Channel migration rates on the Sprague River are slow in relation to many other alluvial rivers of western North America. Mean migration rates range between 0.16 and $0.59 \mathrm{~m} / \mathrm{yr}$ for all analyzed time periods on the mainstem Sprague River. By contrast, the gravel-bed rivers of the Olympic Peninsula have migration rates ranging from $2.1 \pm 1.7 \mathrm{~m} / \mathrm{yr}$ for the lower Elwha River (Draut and others, 2011 ) to $8.8 \pm 4.1 \mathrm{~m} / \mathrm{yr}$ for the Quinault River (O'Connor and others, 2003c). Nanson and Hickin (1986) reported average migration rates of $0.57-8.3 \mathrm{~m} / \mathrm{yr}$ for 18 river reaches in western Canada, and Giardino and Lee (2011) document an average migration rate of $3.28 \mathrm{~m} / \mathrm{yr}$ for the Brazos River, Texas, for an analysis period extending back to 1929 .

Expressed in terms of channel width, most segments had median migration rates of less than 0.01 channel widths per year (fig. 46). Such rates place the Sprague River within Hooke's (2003) class of stable meanders. These rates are also in the low end of the range of migration rates $(0.0003$ to 0.23 channel widths per year ) for other low-gradient rivers like the Sprague River (Dietrich and others, 1999; Gilvear and others, 2000; Brooks, 2003; Micheli and others, 2004; Rodnight and others, 2005; Gautier and others, 2007).

\section{Channel Cutoffs and Avulsions}

The locally high channel migration rates evident for short reaches within the unconfined valley segments (fig. 44) resulted from meander cutoffs and channel avulsions. Such events result in rapid translocation of the primary channel, leaving secondary or backwater channels in their wake (fig. 40). Mapping changes in channel position from the historical aerial photographs and GLO maps (where the channel was meandered in 1872 within the Council Butte and Beatty-Sycan valley segments) show cutoffs and avulsions widely distributed throughout the Sprague and Sycan River system, but more common in the wider and unconfined valley segments (fig. 47). When normalized by length of channel available for comparison and time period, the periods between 1940 and 1975 had the greatest frequency of avulsions, with rates more than twice those of any other time period (table 8). This finding is consistent with the locally very high lateral migration rates determined for those time periods from the flood-plain transect analysis of lateral migration (fig. 44) and probably represent effects of the 1964 flood or possibly human modifications of the channel and flood plain. 


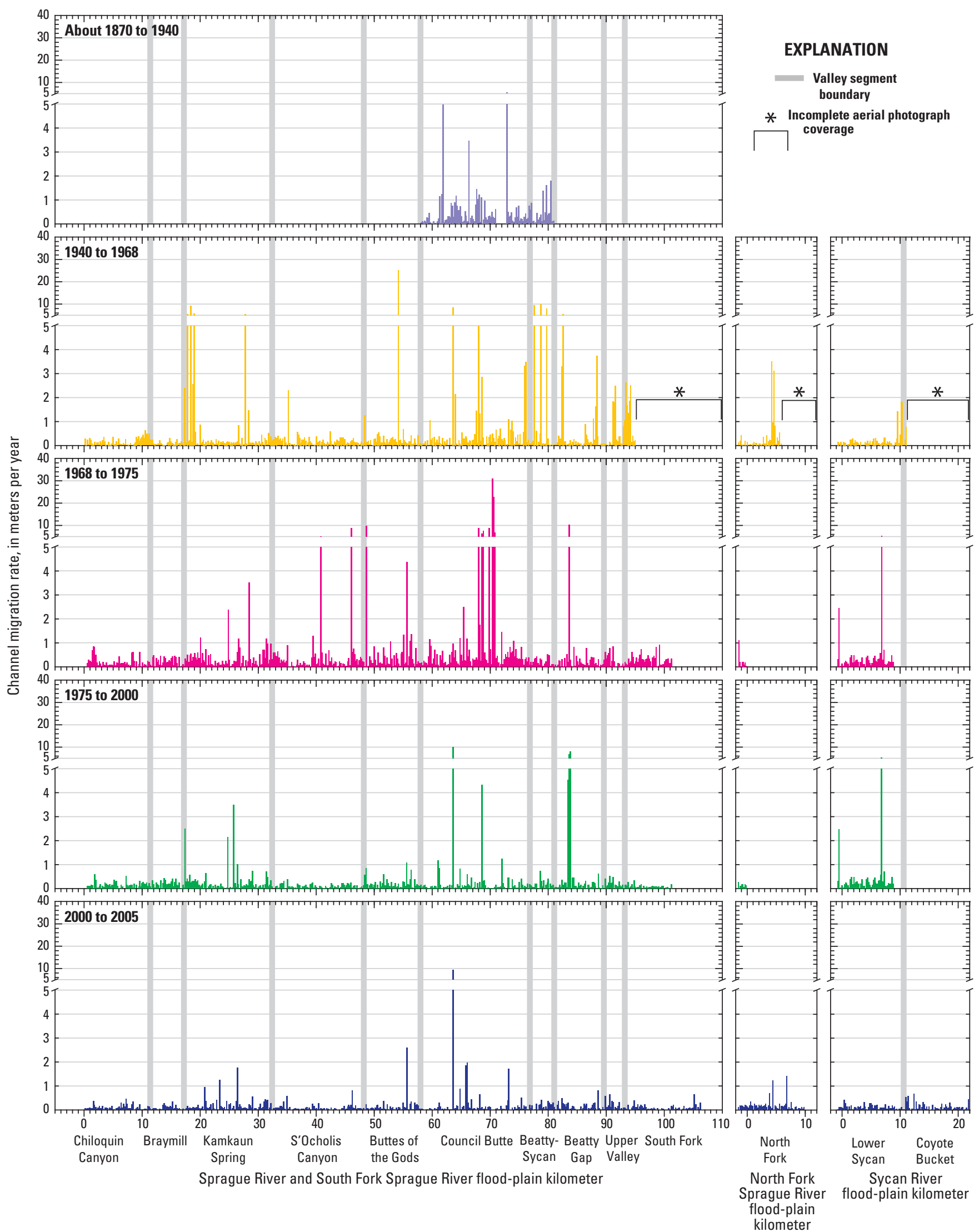

Figure 44. Spatial trends in lateral channel migration rate determined from channel centerline positions, as mapped from General Land Office (GLO) maps and aerial photographs from 1940, 1968, 1975, 2000, and 2005, Sprague River Basin, Oregon. Channel movement was determined from sequential centerline intercepts with flood-plain transects spaced 200 meters apart. GLO to 1940 migration rates were determined only for parts of Council Butte and Beatty-Sycan valley segments where the channel was meandered. Observations from South Fork, North Fork, Lower Sycan, and Coyote Bucket valley segments were limited for some time periods by incomplete map and photographic coverage. 


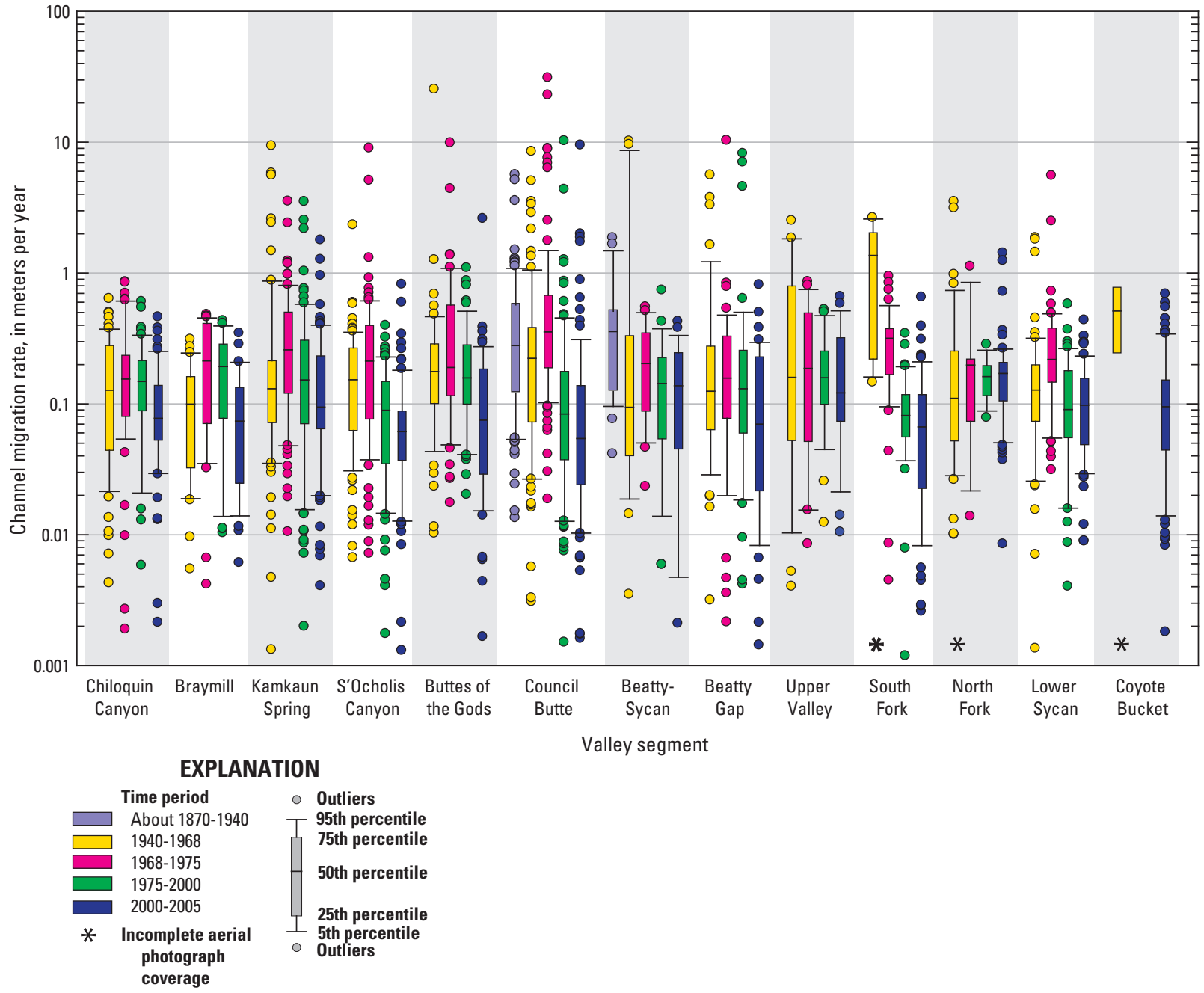

Figure 45. Channel migration rate measurements summarized by valley segment, Sprague River Basin, Oregon. Migration rates are in figure 44.

Table 8. Avulsion and cutoff frequency, Sprague River Basin, Oregon.

[Abbreviations: km/yr, kilometer per year; , approximately]

\begin{tabular}{rcccccc}
\hline Period & $\begin{array}{c}\text { Total } \\
\text { number }\end{array}$ & $\begin{array}{c}\text { Neck } \\
\text { cutoffs }\end{array}$ & $\begin{array}{c}\text { Chute } \\
\text { cutoffs }\end{array}$ & $\begin{array}{c}\text { Indeter- } \\
\text { minate }\end{array}$ & $\begin{array}{c}\text { Frequency } \\
\text { Avulsions }\end{array}$ & $\begin{array}{c}\text { (number/ } \\
\text { km/yr) }\end{array}$ \\
\hline${ }^{1} 1870-1940$ & 3 & 0 & 3 & 0 & 0 & 0.001 \\
${ }^{1} 1940-1968$ & 35 & 7 & 18 & 2 & 8 & 0.007 \\
$1968-1975$ & 16 & 1 & 12 & 1 & 2 & 0.014 \\
$1975-2000$ & 9 & 1 & 7 & 0 & 1 & 0.002 \\
$2000-2005$ & 3 & 0 & 2 & 0 & 1 & 0.003 \\
\hline
\end{tabular}

${ }^{1}$ Incomplete aerial photograph coverage. 


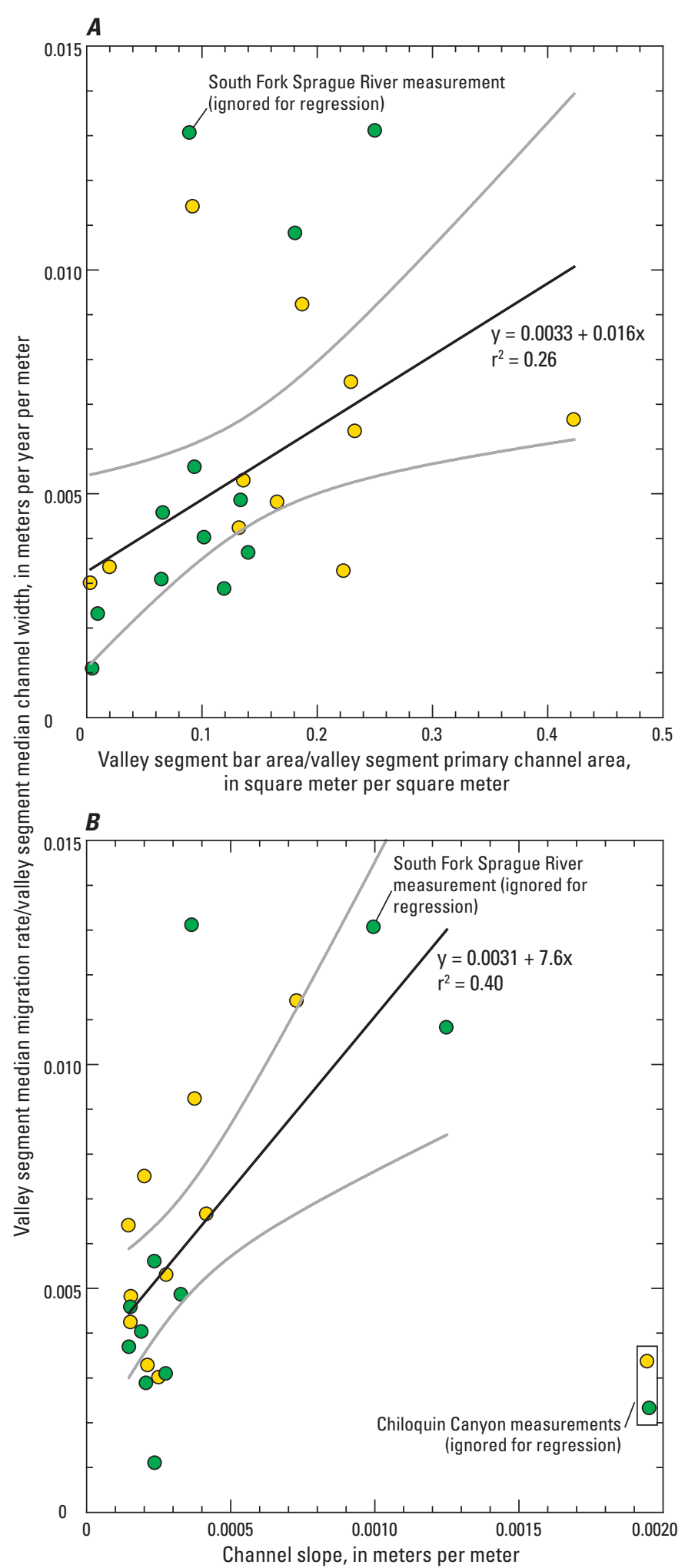

EXPLANATION

1968 bar area; 1940-1968 migration rate $\quad r^{2}$, coefficient of determination

O 2000 bar area; $1968-2000$ migration rate

\section{Channel Incision}

Although long-term channel incision or downcutting is the inevitable consequence of drainage systems eroding landscapes, short-term episodes of channel incision into flood plains can lead to many morphologic, ecologic, and water-quality consequences to the fluvial system (Williams and Wolman, 1984; Schumm, 1999; Simon and Rinaldi, 2006; Shields and others, 2010; Cluer and Thorne, 2013). Such short-term incision can be triggered by land-use changes, changes in hydrologic regime, and channelization, among other causes. Once incision begins in alluvial channel systems, it typically propagates upstream and leads to an enduring sequence of channel evolution involving downcutting and widening before establishment of a new flood-plain inset within the original flood-plain surface (Simon and Hupp, 1986; Cluer and Thorne, 2013). In certain environments, recovery to pre-incision states requires decades or centuries (Beechie and others, 2008), while in others a compound cross section composed of a narrow flood plain laterally constrained by paired terraces may persist for similar lengths of time. Therefore, preventing or reversing channel incision is a common goal of watershed and channel restoration (Palmer and others, 2005; MacWilliams and others, 2010). Incision has been a concern in the Sprague River Basin (Connelly and Lyons, 2007; Rabe and Calonje, 2009).

\section{Stratigraphic Analysis}

The stratigraphic records and augering transects provide a century-to-millennial scale perspective on historical channel incision. Along the main-stem Sprague River and lower Sycan River, the stratigraphic sections recording older stratigraphy locally show pre-Mazama fluvial gravel as much as $2 \mathrm{~m}$ higher than the present channel bed (fig. 4), indicating channel and flood-plain formation higher than present levels prior to $7,700 \mathrm{cal}$ yr BP. Subsequent incision may represent overall valley excavation, but more likely the higher channels and flood plains (now terraces) of the late Pleistocene and early Holocene represent higher sediment loads and flow regimes, similar to conditions in the Willamette Valley (O'Connor and others, 2001) and the Oregon Coast Range (Personius and others, 1993) where greater sediment (owing to more intense physical weathering) and water fluxes during colder Pleistocene climates resulted in regional aggradation.

Figure 46. Migration rate correlations and confidence intervals along valley segment summarized variables, Sprague River Basin, Oregon. (A) Normalized bar area and migration rate (normalized by median channel width) and (B) channel slope and normalized migration rate. 


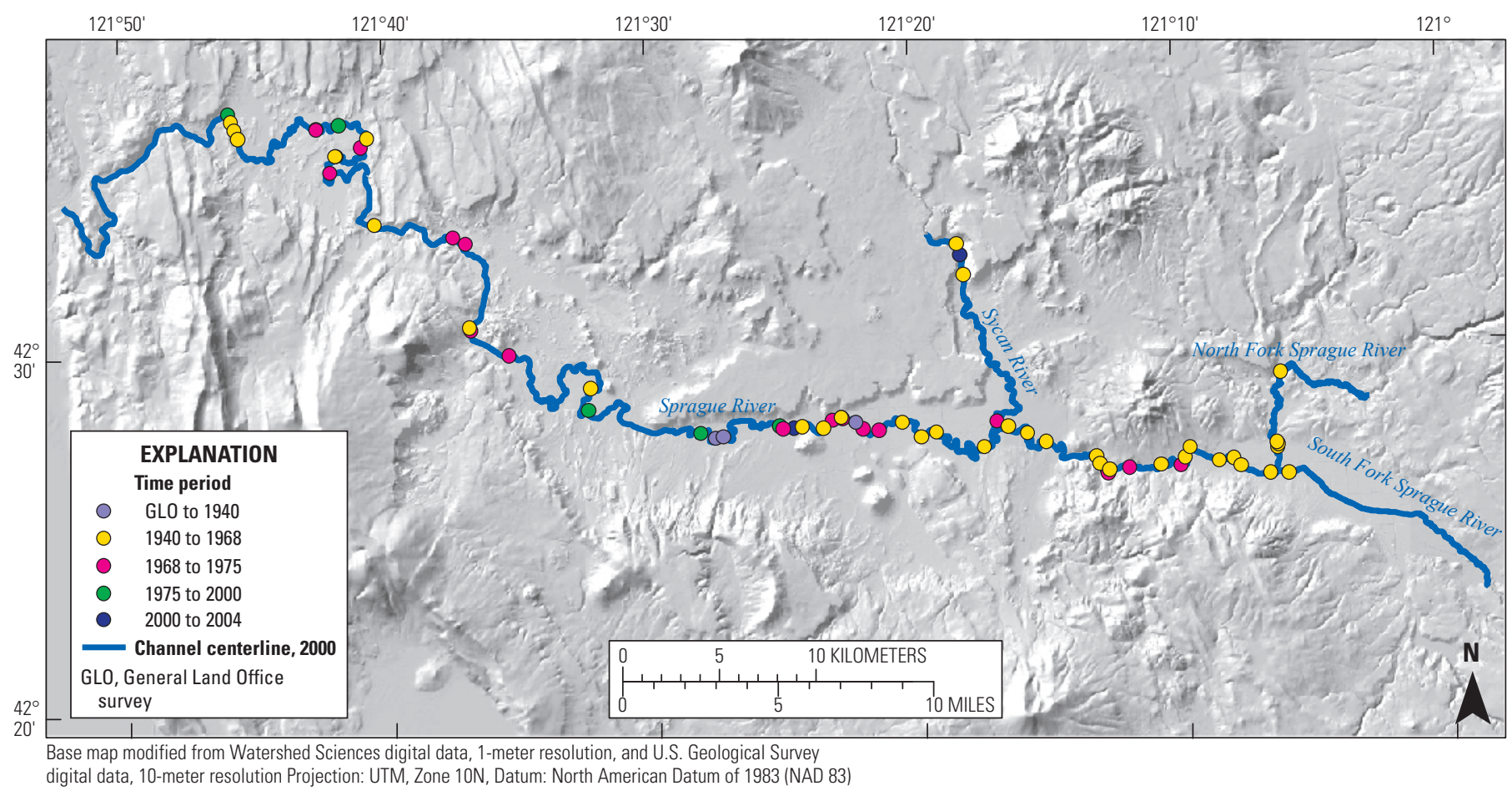

Figure 47. Locations and timing of avulsions and cutoffs evident from map and aerial photograph analysis, Sprague River Basin, Oregon.

However, subsequent to the Mazama eruption of about 7,700 years ago, the stratigraphic exposures and augering indicate little or no overall channel incision for most of the Sprague River study area. The base of paleochannels (abandoned as much as 3,800 cal yr BP) probed during the augering transects near FK 31 and 48 are as much as $1 \mathrm{~m}$ lower than the present channel to $0.2 \mathrm{~m}$ higher, indicating little net incision and perhaps even aggradation of the valley bottom in the Kamkaun Spring and Buttes of the Gods valley segments during the late Holocene (igs. 12, 13). Similarly, the bank exposures of post-Mazama flood-plain stratigraphy along the main-stem Sprague River, North Fork Sprague River, and Sycan River show channel gravels nowhere more than $40 \mathrm{~cm}$ above the present base-flow water surface (figs. 5, $\underline{8}, \underline{9}$ ). Modern (2006) coarse sand and gravel deposition to similar or higher levels on point bars during high flows also indicate that the present channel is not incised (fig. 14). Similar to the auger probes, several sections show channel deposits of the last 1,000-2,000 years as much as $50 \mathrm{~cm}$ below the present channel bottom, also indicating late Holocene channel aggradation.

Stratigraphic exposures along the North Fork Sprague River and the Sycan River indicate episodes of flood-plain erosion and construction possibly resulting from different hydrologic and sediment regimes. Along the North Fork Sprague River, an actively aggrading flood plain less than
$300 \mathrm{cal}$ yr BP is inset into an older flood plain as much as 4,700 cal yr BP (igs. 9, 11). The older flood-plain deposits along the North Fork Sprague River are distinctive because of a 0.5 -m-thick peat and diatomaceous horizon, indicating a significant period of wet flood-plain conditions with little sediment transport sometime after 4,330 cal yr BP (fig. 9).

Similarly, the Sycan River is flanked by low floodplain surfaces that began accumulating overbank deposits as recently as $600 \mathrm{cal}$ yr BP (fig. 5). In some locations, this younger flood plain is inset against taller and older flood-plain deposits that began accumulating soon after the approximately 7,700 cal yr BP Sycan flood (Lind, 2009). For the Sycan River and North Fork Sprague River, however, there is no evidence of substantial and persistent changes in channel altitude associated with these multiple episodes of flood-plain formation and erosion.

Channel incision is evident, however, in the stratigraphy exposed at the single investigated site along the South Fork Sprague River (fig. 8). Here, the base of post-Mazama channel and bar deposits is about $50 \mathrm{~cm}$ above the present thalweg. The top of a $60-\mathrm{cm}$ thick diatomaceous peat layer, probably actively accumulating deposits at the time of the first GLO surveys (judging from surveyor descriptions of a swampy flood plain during their September 1866 traverse), was more than $1.6 \mathrm{~m}$ above the water surface at the time of description in 2007. 


\section{Channel Centerline Altitude Changes}

Trends in channel incision are more challenging to document quantitatively from historical sources such as aerial photographs than are planform changes. In some instances, repeat longitudinal topographic and cross section surveys can indicate spatial and temporal trends in channel incision (for example, Wallick and others, 2010, 2011). However, for the Sprague River study area, no such surveys are known. Therefore, to evaluate possible channel altitude changes across time, we have used the channel centerline mapping in conjunction with the lidar topography to estimate changes in channel altitude across time within the study area (fig. 48).

This analysis entailed determining altitudes from the 2004 lidar at intercepts between the flood-plain transects, spaced $200 \mathrm{~m}$ apart, for the length of the study area, and channel centerlines, as mapped from each of the historical map and aerial photograph sources (figs. 48, 49). No analysis is possible at the many such intercepts where lidar altitudes are missing because of specular reflection during the 2004 acquisition, mainly in the Kamkaun Spring valley segment. Furthermore, for locations where the channel has not moved during the analysis period, the location of the intercept remains the same, thus, the altitude obtained from the 2004 lidar also remains constant, and trends cannot be determined. However, for locations where the channel had shifted and lidar altitude is available, the difference in altitude can be determined between the channel intercept of the first location and that of subsequent channel positions. This difference owes to the combined consequences of (1) actual channel altitude changes, (2) differential rates of overbank aggradation and paleochannel filling within abandoned channel traces, and (3) errors in the lidar altitude data. Resolution of these errors is possible only where thalweg gravel altitudes can be surveyed precisely for many channel centerlines at a single transect, as has been done with the augering transects for the prehistoric paleochannels (figs. 12, 13).

Because such surveys of channel deposits have not been conducted for the 1940-2005 centerlines, evaluation is approximate and emphasizes overall spatial and temporal trends rather than changes at specific transects. Local differences of less than about $1 \mathrm{~m}$ in channel altitudes between time periods could relate to lidar altitude errors as well as paleochannel filling or lateral flood-plain accretion rather than changes in actual channel altitude, especially for the more recent and shorter time periods after 1968. Larger changes owing to deposition are plausible for the 1870-1940 period. Coherent patterns over several kilometers, and particularly over many time periods, however, likely indicate systematic changes in channel altitude across time.

From this perspective, the strongest evidence for persistent channel incision is within the South Fork and Upper Valley segments (fig. 49). Observations for the South Fork are incomplete because of limited aerial photograph coverage for some periods, but channel lowering is apparent for much of the Sprague River above FK 90.0, perhaps extending

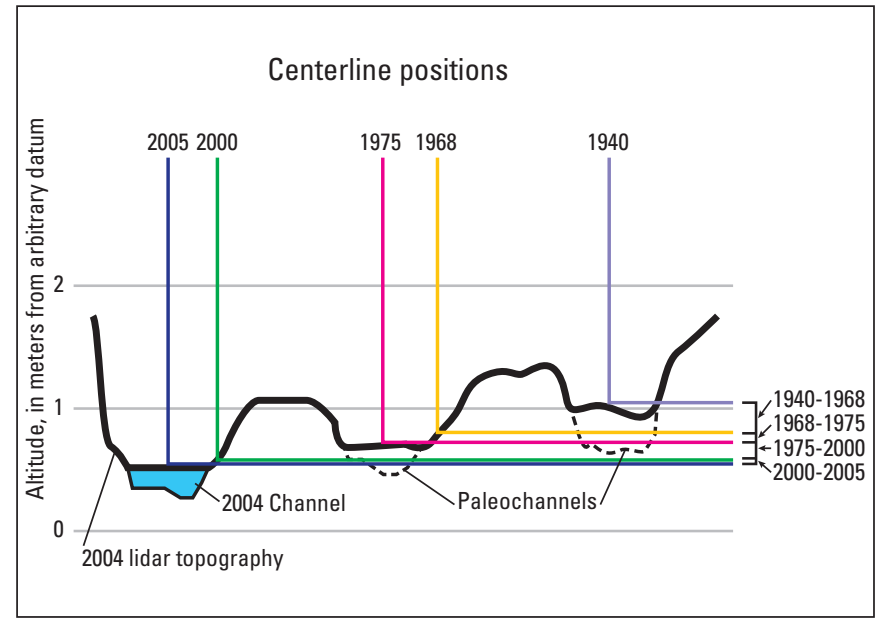

Figure 48. Flood-plain transect, illustrating the approach for assessing vertical channel movement from intercepts between channel centerline positions and 2005 lidar topography, Sprague River study area, Oregon.

downstream to FK 86.0 in the Beatty Gap valley segment. For the 1940-1968 period, apparent incision exceeded $1 \mathrm{~m}$ in many locations within these three valley segments, with lowering also possibly evident in the Council Butte valley segment during this time period. After 1968, however, changes in channel centerline altitude show no systematic changes along the main-stem Sprague River.

Incision in the North Fork Sprague River valley segment is difficult to assess because of limited aerial photograph coverage. Nevertheless, local incision, or more likely, lateral migration with rapid bar and flood-plain building, may be indicated by as much as a $1.3-\mathrm{m}$ difference in present centerline altitudes between NFFK 2.0 and 4.0 for 2000 and 2005 channel locations (fig. 49). The Sycan River shows little spatial or temporal systematic patterns in channel altitude changes, except for the downstream part of the Coyote Bucket valley segment, which likely represents bar and flood-plain building.

Figure 49. (On opposite page) Spatial trends in channelcenterline altitude differences, as mapped from 2004 (lidar) in conjunction with sequential channel centerline positions, as mapped from General Land Office (GLO) maps and aerial photographs taken in 1940,1968, 1975, 2000, and 2005, Sprague River study area, Oregon. Measurements at flood-plain transects are spaced 200 meters apart. GLO-to-1940 channel-altitude differences were determined only for parts of Council Butte and Beatty-Sycan valley segments where channel was meandered. Observations from South Fork, North Fork, Lower Sycan, and Coyote Bucket valley segments are limited for some time periods by incomplete map and photographic coverage. 


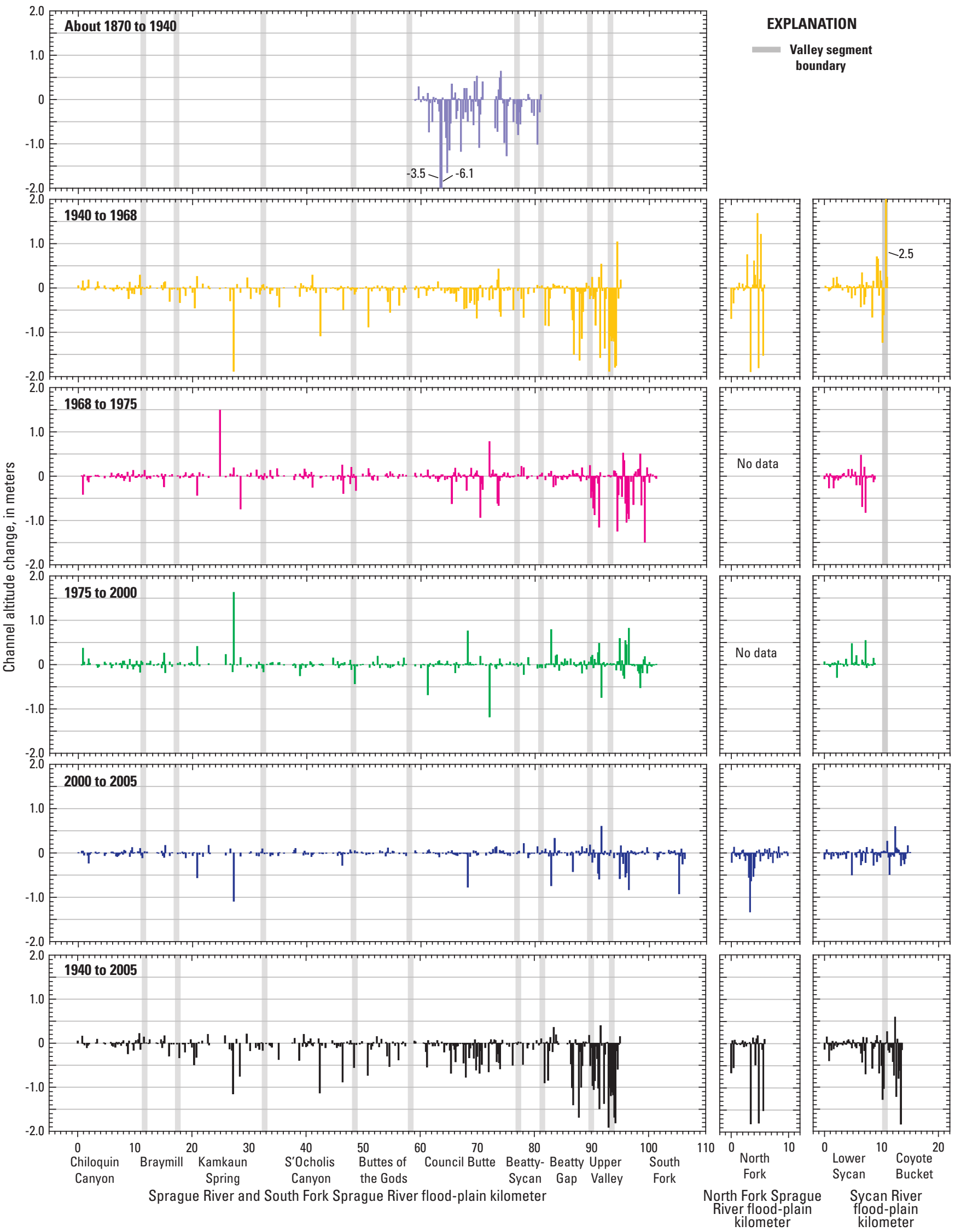


Results of this centerline analysis are consistent with the stratigraphic records: There is no evidence of substantial incision throughout most of the Sprague River corridor. The main areas of likely historical incision are in the South Fork valley segment, and possibly in parts of the Upper Valley and Beatty Gap valley segments, although this incision mostly pre-dates 1975.

\section{Effects of the 2006 High Flows}

High flows in 2006 (fig. 50) provided an opportunity to investigate channel and flood-plain processes associated with the greatest flooding since WY 1999 (since WY 1996 on the Sycan River and on the Sprague River near Beatty Gap; fig. 2). In WY 2006, mean daily discharge exceeded $80 \mathrm{~m}^{3} / \mathrm{s}$ on the Sprague River near Chiloquin (streamflow-gaging station 11501000) for many days in December and January from rain and snowmelt, with the largest discharge of $101.7 \mathrm{~m}^{3} / \mathrm{s}$ on January 5, 2006. Earlier during this period of high flow, peak flow exceeded $86 \mathrm{~m}^{3} / \mathrm{s}$ on January 1, 2006 at the Sprague River streamflow-gaging station (station 11497500) near Beatty Gap. During the following spring, regional snowmelt raised flows in April and May 2006, resulting in two peaks of about $90 \mathrm{~m}^{3} / \mathrm{s}$ near Chiloquin. The Sycan River also had its greatest flow of the year during this late April and early May snowmelt flow, peaking at $67 \mathrm{~m}^{3} / \mathrm{s}$ on May 1, 2006. The combined effects of the December-January and April-May runoff episodes were two peaks on the main-stem Sprague River, both exceeding $90 \mathrm{~m}^{3} / \mathrm{s}$, but the first of shorter duration compared to the longer spring runoff to which the Sycan River also contributed significantly (fig. 50).

\section{Distribution and Character of Flood Deposits}

Between June 23 and July 15, 2006, the effects of these large flows were surveyed by mapping and measuring deposit characteristics along most of the main-stem Sprague River. At each of 70 measurement sites (fig. 51), spaced an average of $1.7 \mathrm{~km}$ apart, we measured deposit thickness, texture, and altitude relative to the low-flow water surface, and, where possible, surveyed the altitude of the highest evidence of flow from WY 2006 (fig. 52; appendix G).

The goal of these surveys was to sample sites of evident deposition at about $1-\mathrm{km}$ intervals along the river corridor. Sparse deposits in some reaches necessitated longer distance intervals, as did time constraints imposed by far-spaced river access locations. Therefore, distance intervals between sample locations are not even, with larger gaps between sites mainly in the Council Butte, Buttes of the Gods, and S'Ocholis Canyon valley segments. Each depositional site was classified as either a bar or flood-plain deposit (appendix G).

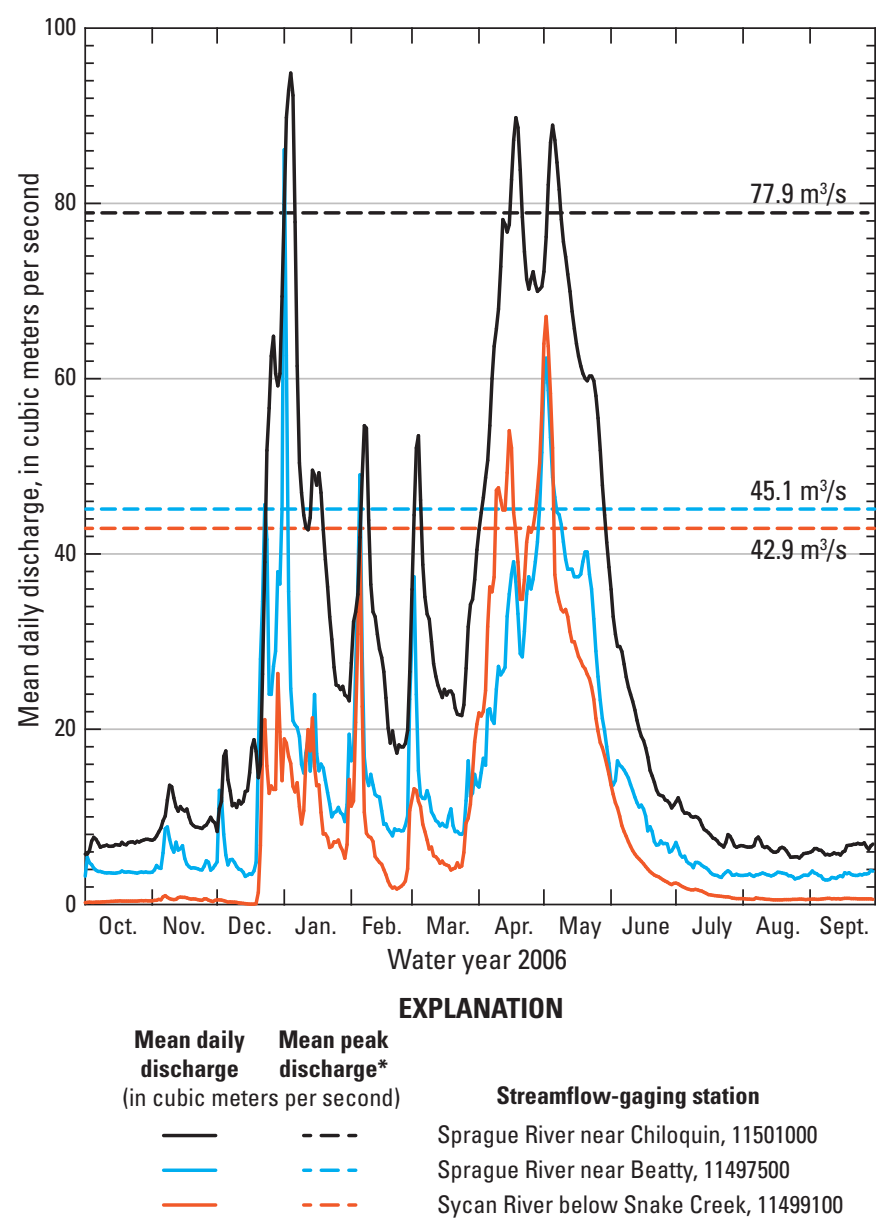

* Mean peak annual discharge for period of record: Sprague River near Chiloquin $=77.9 \mathrm{~m}^{3} / \mathrm{s}$ (1921-2011 with gaps) Sprague River near Beatty $=45.1 \mathrm{~m}^{3} / \mathrm{s}$ (1914-1991 with gaps) Sycan River below Snake Creek $=42.9 \mathrm{~m}^{3} / \mathrm{s}(1974-2007)$

Figure 50. Mean daily discharge during water year 2006 for select streamflow-gaging stations, Sprague River Basin, Oregon.

At each sampling site, we excavated through the 2006 flood deposits to the preexisting surface, apparent at all sites by buried vegetation (fig. 53). At some locations, we could infer separate deposits resulting from the two high-flow episodes on the basis of stratigraphic breaks or more definitively by young vegetation that had germinated in the intervening period between the early January peak and the April and May high flows. However, distinguishing the deposits from the specific high flows generally was not possible, so the total thickness and texture of the deposit was measured and summarized for analysis. Texture was fieldcategorized into broad grain-size classes ranging from gravel to silt-clay. 


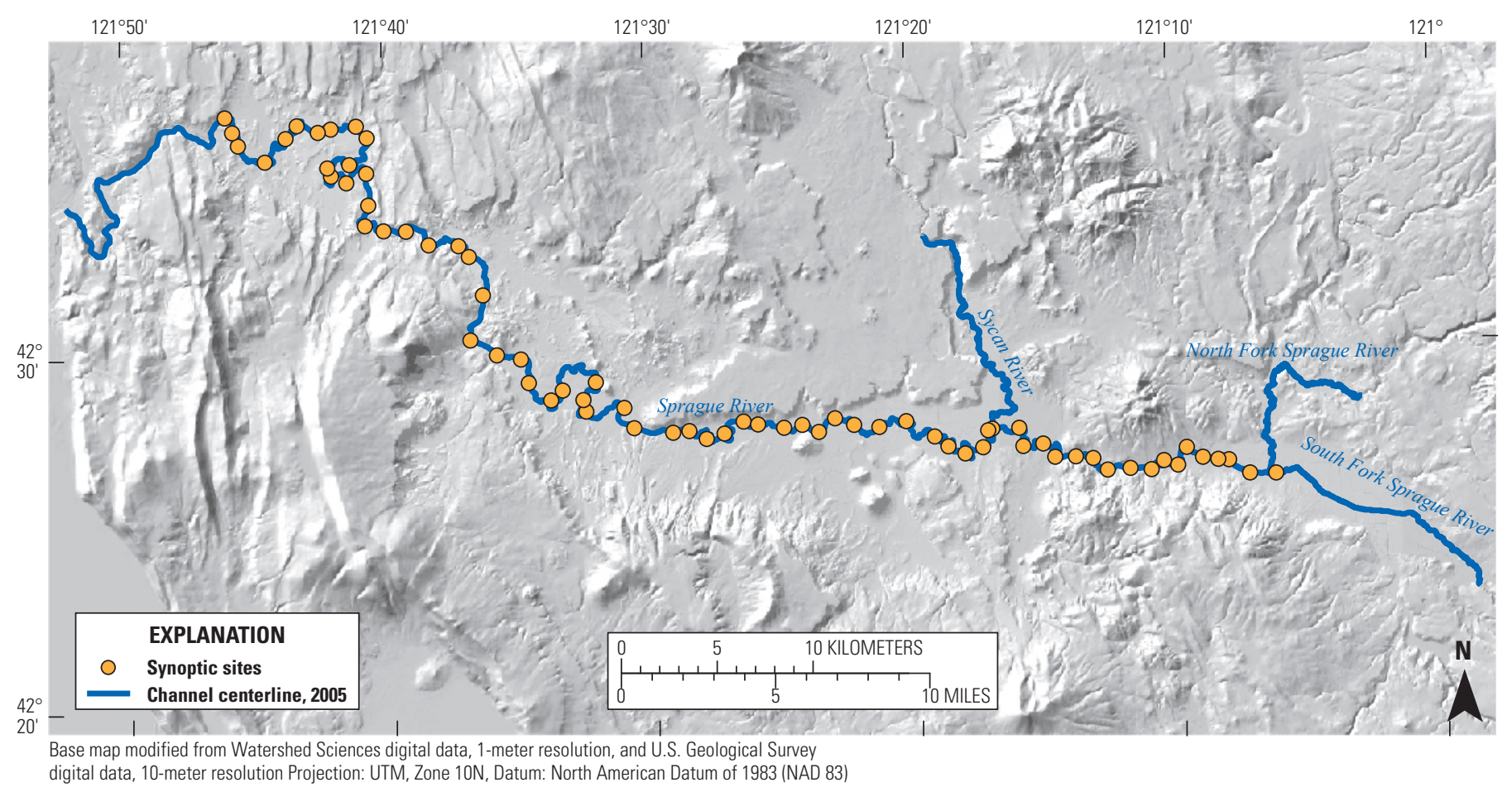

Figure 51. Sites assessed in the summer of 2006 for water year 2006 sediment deposition and flood altitude, Sprague River Basin, Oregon.

The top of the excavated sequence at each site was surveyed relative to the Sprague River water surface by hand level and stadia. Additionally, the highest preserved evidence of 2006 flow stage was surveyed, commonly consisting of flotsam or detritus entangled in vegetation and fencing. In locations of low flood plains, this evidence provides a minimum local estimate of the maximum 2006 flood stage. During the course of mapping, the Sprague River flow varied from $8.7 \mathrm{~m}^{3} / \mathrm{s}$ to $12.7 \mathrm{~m}^{3} / \mathrm{s}$. Therefore, all surveyed altitudes were adjusted to a reference discharge of $11.5 \mathrm{~m}^{3} / \mathrm{s}$ (which slightly exceeds the median daily flow of $9.7 \mathrm{~m}^{3} / \mathrm{s}$ ) on the basis of the stage-discharge rating for USGS streamflow gaging-station 11501000, Sprague River near Chiloquin, Oregon, at FK 8.3. This resulted in altitude adjustments ranging between -0.22 and $0.08 \mathrm{~m}$ (appendix $\mathrm{G}$ ).

Maximum flood stages along the main-stem Sprague River were highest in the confined valley segments, such as Beatty Gap and S'Ocholis Canyon, and downstream in the Kamkaun Spring valley segment (figs. 52, 54). In several reaches, maximum flood stage was more than $2 \mathrm{~m}$ higher than the altitude of the $11.5 \mathrm{~m}^{3} / \mathrm{s}$ reference discharge. The lowest flood stages were in the wide and low-gradient Council Butte and Buttes of the Gods valley segments, where maximum 2006 flood stages were 1.2-1.5 m above the reference altitude. Even in these reaches, however, maximum flood stages inundated large areas of the flood plain.
Deposit distribution and characteristics varied among the valley segments (fig. 52). The thickest, coarsest, and some of the highest deposits are in the Beatty Gap valley segment, where coarse sand was deposited as high as $1.85 \mathrm{~m}$ above the reference discharge altitude. By contrast, no flood deposits were observed more than $1 \mathrm{~m}$ above the reference discharge altitude in the Beatty-Sycan, Council Butte, or Buttes of the Gods valley segments. Coarse sand and gravel typically was deposited within $1 \mathrm{~m}$ of the reference discharge stage. Finer sand, silt, and clay were the dominant constituents of higher deposits.

The thickest and coarsest deposits were on bars, whereas finer and thinner deposits typified flood-plain depositional sites (figs. 52 and $\underline{53}$ ). For example, the median 2006 deposit thickness on bars was $21 \mathrm{~cm}$, whereas the median accumulation on flood plains was about $4 \mathrm{~cm}$. All bar deposits were sand and gravel. By contrast, more than 60 percent of the flood-plain sites accumulated fine sand, silt, or clay, typically at altitudes higher than bar sites. Where stratigraphy was evident, inclined bedding indicated that most of the bars formed by lateral accretion, contrasting with horizontally bedded vertical accretion on flood plains. This pattern is consistent with the long-term stratigraphic records, especially those on the North Fork Sprague River and Sycan River where stratigraphic relations indicate laterally accreted coarse sand transitioning up into vertically accreting finer sand and silt (figs. 11, 14). 

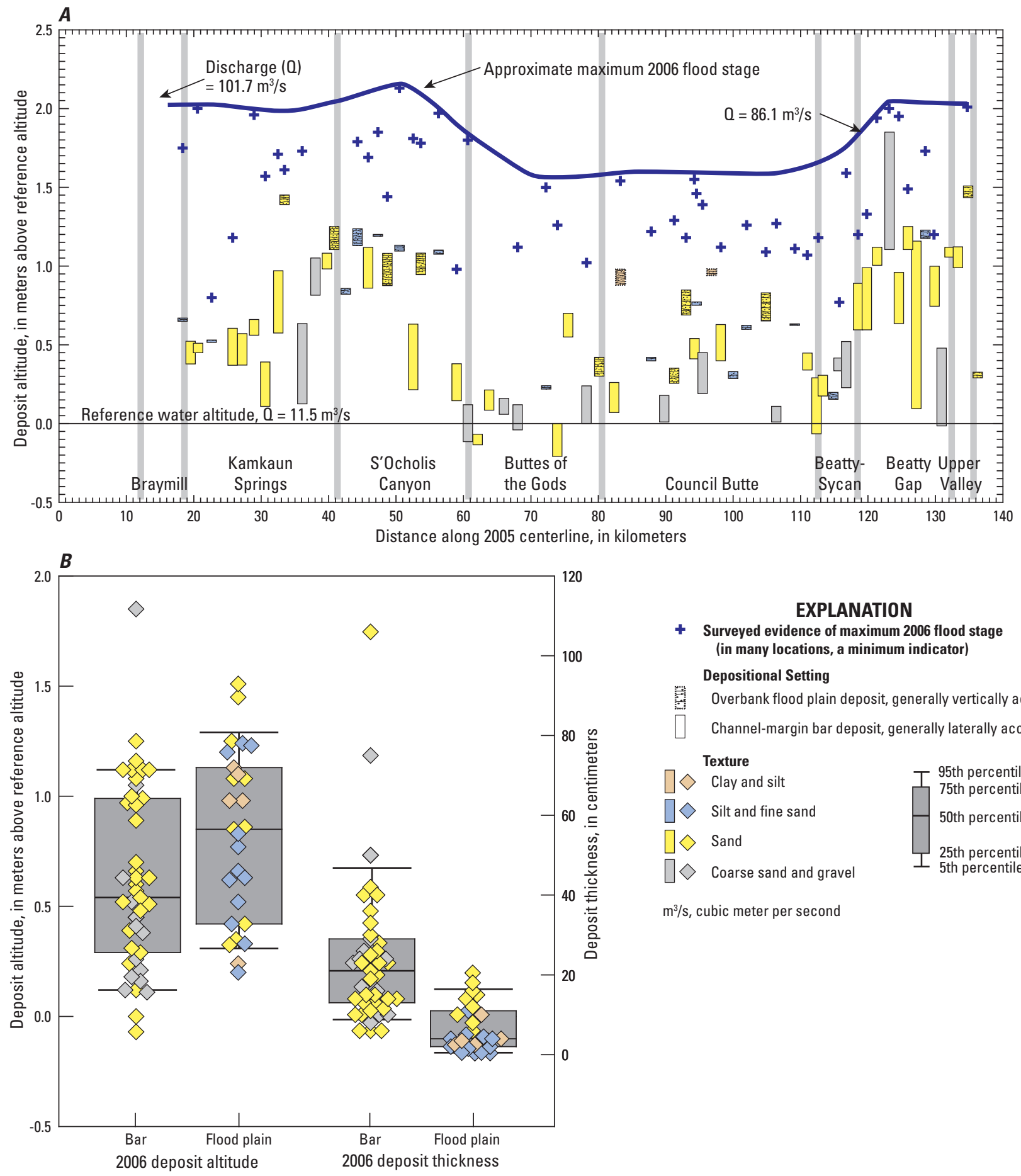

\section{EXPLANATION}

+ Surveyed evidence of maximum 2006 flood stage (in many locations, a minimum indicator)

Depositional Setting

Overbank flood plain deposit, generally vertically accreted

$\square$ Channel-margin bar deposit, generally laterally accreted

\section{Texture}

$\nabla$ Clay and silt

$\oslash$ Silt and fine sand

$\sqcap$ Sand

$\sqcap$ Coarse sand and gravel

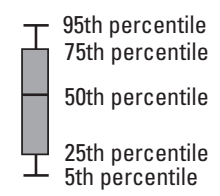

$\mathrm{m}^{3} / \mathrm{s}$, cubic meter per second

Figure 52. Summary observations of 2006 survey of deposits and inundation levels of water year 2006 floods, including $(A)$ longitudinal trends of deposits and inundation evidence (with peak flow values from Sprague River near Chiloquin [streamflow-gaging station 11501000] and Sprague River near Beatty [streamflow-gaging station 11497500]; peak flow at both sites was on January 1, 2006); and (B) summary plots of 2006 flood deposit texture and altitude, grouped by bar and flood-plain settings, main-stem Sprague River, Oregon. No observations were made in the Chiloquin Canyon valley segment. All altitudes are adjusted to the stage associated with 11.5-cubic-meters-per-second discharge (0) at U.S. Geological Survey streamflow-gaging station 11501000. 


\section{$\boldsymbol{A}$}

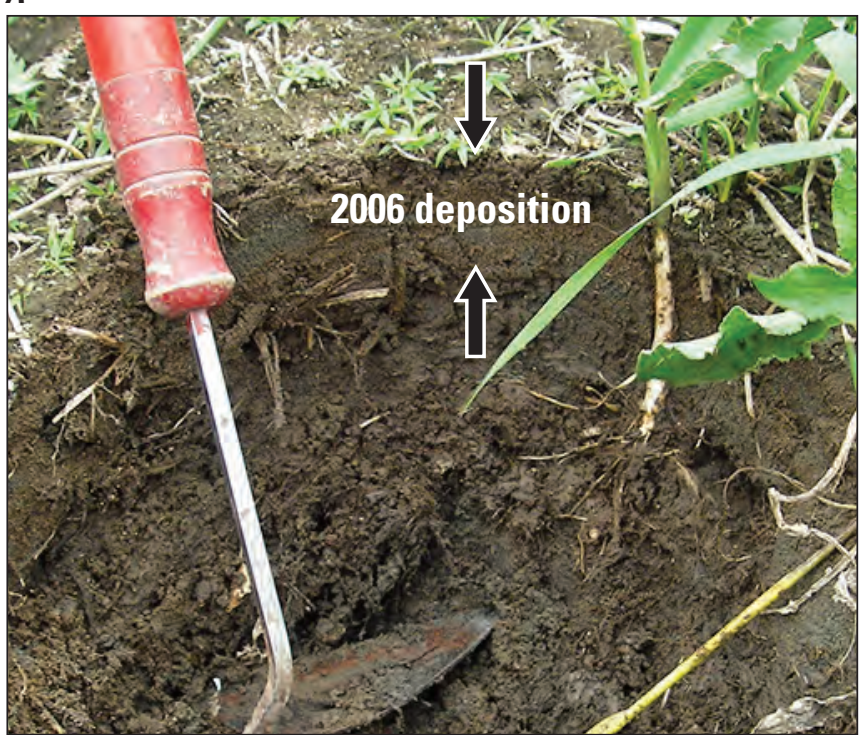

B

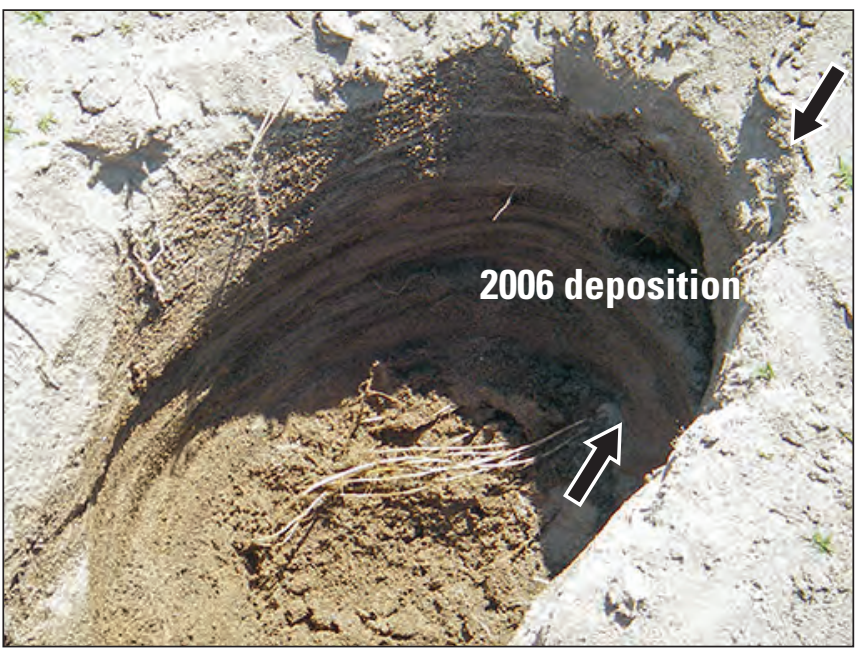

Figure 53. Examples of sediment deposition resulting from the 2006 high flows, including $(A)$ overbank deposition of 4.5 centimeters of silt and sand on low flood-plain surface, Council Butte valley segment (survey site 6/28/06-8); and $(B)$ deposition of 33 centimeters of sand on point bar, Beatty Gap valley segment (survey site 6/26/06-1), main-stem Sprague River, Oregon. Photographs taken by J.E. O'Connor, U.S. Geological Survey; (A) June 28, 2006; (B) June 26, 2006.

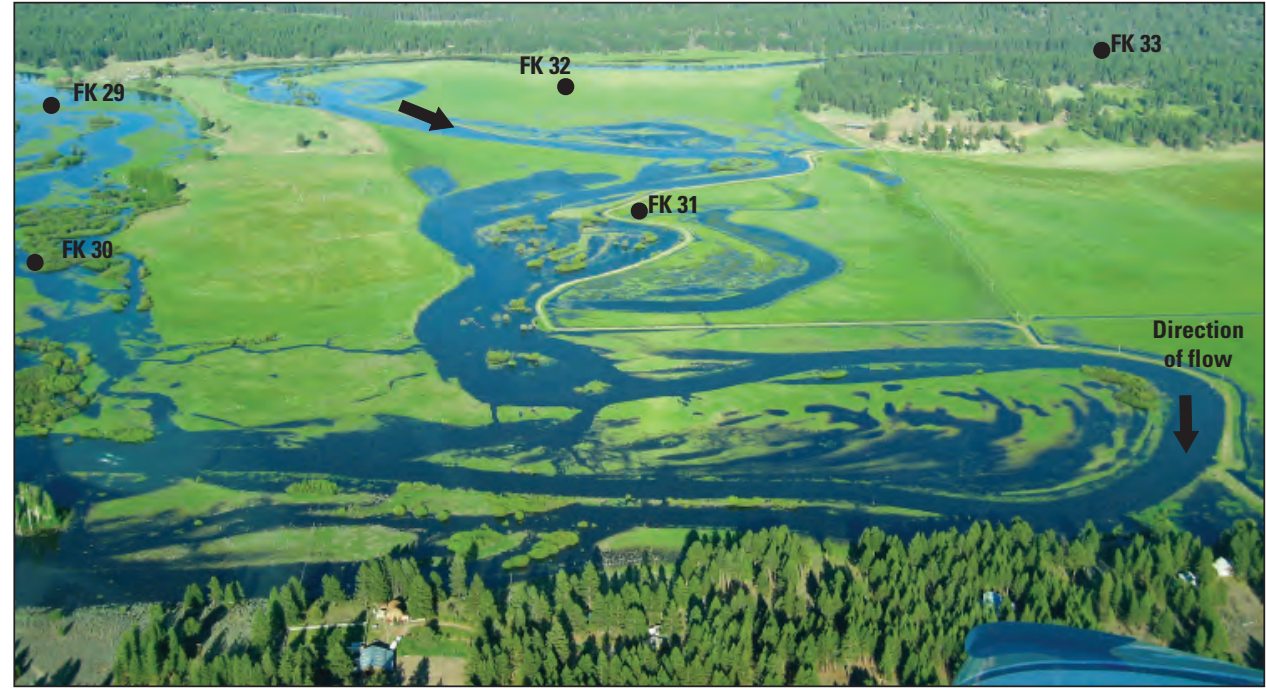

Figure 54. Kamkaun Spring valley segment, looking north, main-stem Sprague River, Oregon, during high flow in water year 2006. Photograph courtesy of Greg Koonce, Inter-Fluve Inc., May 16, 2006 (used with permission). 
Nearly all the sand and gravel particles, particularly in the coarse sand-to-granule range of $1-4 \mathrm{~mm}$, were lightcolored pumice grains (fig. 53B ). This observation also is consistent with the stratigraphic records from the length of the study reach, which show nearly all coarse sand deposits that post-date the Mazama eruption dominantly composed of pumiceous materials.

\section{Measured Sediment Transport}

In a sediment study commissioned by The Klamath Tribes, Graham Matthews and Associates (2007) measured streamflow and sediment transport at 14 sites in the Sprague River Basin between February 2004 and January 2006. Included in this measurement period is the high flow resulting from the winter storm of late December 2005 and early January 2006 (fig. 50). During these elevated flows, Graham Matthews and Associates (2007) report four to eight suspended sediment measurements from each of seven sites along the main-stem Sprague River, Sycan River, South Fork Sprague River, and North Fork Sprague River (fig. 55). Five of these sites are within the study area; the other two are on the North Fork and South Fork Sprague Rivers less than $5.5 \mathrm{~km}$ upstream of the alluvial part of the river corridors within the study area.

Flow at all sites peaked on December 31,2005, except for the main-stem Sprague River site at Godawa Springs Road, which peaked the next day on January 1, 2006, and the Sycan River site at SYFK 2.3, which peaked a week earlier on December 23, 2005 (Graham Matthews and Associates, 2007). Sediment concentration measurements were made at discharges ranging from $2.61 \mathrm{~m}^{3} / \mathrm{s}$ (with a suspended-sediment flux of 0.0055 kilogram per second $[\mathrm{kg} / \mathrm{s}])$ on the North Fork Sprague River at Road 3411 (5.5 km upstream of the study area) to $74.2 \mathrm{~m}^{3} / \mathrm{s}$ (with suspended-sediment load of $38.8 \mathrm{~kg} / \mathrm{s}$ ) on the Sprague River at Godawa Springs Road (FK 78.2) (Graham Matthews and Associates, 2007). This $74.2 \mathrm{~m}^{3} / \mathrm{s}$ measurement at the most downstream site was very close to the peak flow of $75.4 \mathrm{~m}^{3} / \mathrm{s}$ on January 1, 2006 . Additionally, this measurement site had the highest measured sediment concentration of 523 milligrams per liter $(\mathrm{mg} / \mathrm{L})$. They also made measurements at discharges within 95 percent of the peak discharge on December 31, 2005 for the North Fork Sprague River at NFFK 0.7, South Fork Sprague River at Picnic Area (1.5 km upstream of where the South Fork Sprague River enters the study area, equivalent to FK 107.6), South Fork Sprague River upstream of Fishhole Creek (FK 100.1), and South Fork Sprague River at Ivory Pine Road (FK 94.3).

In addition to high sediment concentrations near the time of peak discharge, all sites had high sediment concentrations and mass flux early during the measurement period. Later measurements at all sites showed substantial decreases in concentrations and flux during the course of the flood (fig. 55). This hysteresis (changing sediment concentration relative to streamflow during a period of high flow) is most evident for the upstream and tributary sites, where sediment fluxes decrease by a factor of 10 or more relative to discharge on the North Fork Sprague River at Road 3411, South Fork Sprague River at Picnic Area, and Sycan River at Drews Road. Hysteresis is present but to a lesser degree on the other downstream sites, particularly the main-stem Sprague River at Godawa Springs Road, where sediment concentration decreased by a factor of five during the flood.

Such hysteresis commonly owes to sediment depletion during the period of high flow. Sediment depletion may be more rapid in smaller streams and during initial wet-season flows (Williams, 1986; Smith and Dragovich, 2009). The pronounced peak in sediment fluxes and concentrations associated with peak flows in the Sprague River indicates entrainment from additional sediment sources at high flows (likely bank and channel materials), as well as from floodplain diversion channels (Michael Hughes, Oregon Institute of Technology, written commun., 2013).

The spatial evolution of sediment concentrations also clarifies sediment sources, especially along the South Fork and main-stem Sprague Rivers. Four sites had closely coincident measurements, including measurements at very close to peak discharge (fig. 56; Graham Matthews and Associates, 2007). These measurements show suspended sediment concentration markedly increasing between the South Fork Sprague River at Picnic Area (FK about 107.6) and the next downstream site above Fishhole Creek (FK 100.1). At peak discharge and for the three measurements leading up to the peak flow, sediment concentration increased in this 6.5 -km-long reach by factors ranging from 1.4 to 4.8 , despite the drainage area increasing only by a factor of 1.2. For the December 21, 23, 30 and 31 measurements, sediment concentrations diminished downstream of the measurement site upstream of Fishhole Creek. Together, these measurements indicate significant sediment entrainment in the South Fork valley segment above FK 100.1. Because tributaries are few in this reach, channel and bank erosion was probably a source of some of this suspended sediment. Additional sources of sediment in this reach likely include eroding bank crevasses or cuts, which facilitate sediment transport from flood-plain surfaces and irrigation channels into the South Fork Sprague River (Michael Hughes, Oregon Institute of Technology, written commun., 2013).

Entrainment patterns apparently changed at or soon after peak flow. On January 1, 2006, sediment concentrations and total flux increased downstream, culminating with a sediment concentration of $523 \mathrm{mg} / \mathrm{L}$ (and a suspended load flux of $38.8 \mathrm{~kg} / \mathrm{s}$ ) on the Sprague River at Godawa Springs Road (FK 78.2). This pattern also was indicated by the January 6, 2006 measurements, although at much lesser levels. 
EXPLANATION

- Discharge, outline indicates measurement near peak discharge

- $\square$ Sediment flux, outline indicates measurement near peak discharge

$\rightarrow$ Stream network relations

Abbreviations: $\mathrm{km}^{2}$, square kilometer; NFFK, North Fork Sprague River flood-plain kilometer SYFK, Sycan River flood-plain kilometer; FK, flood-plain kilomete

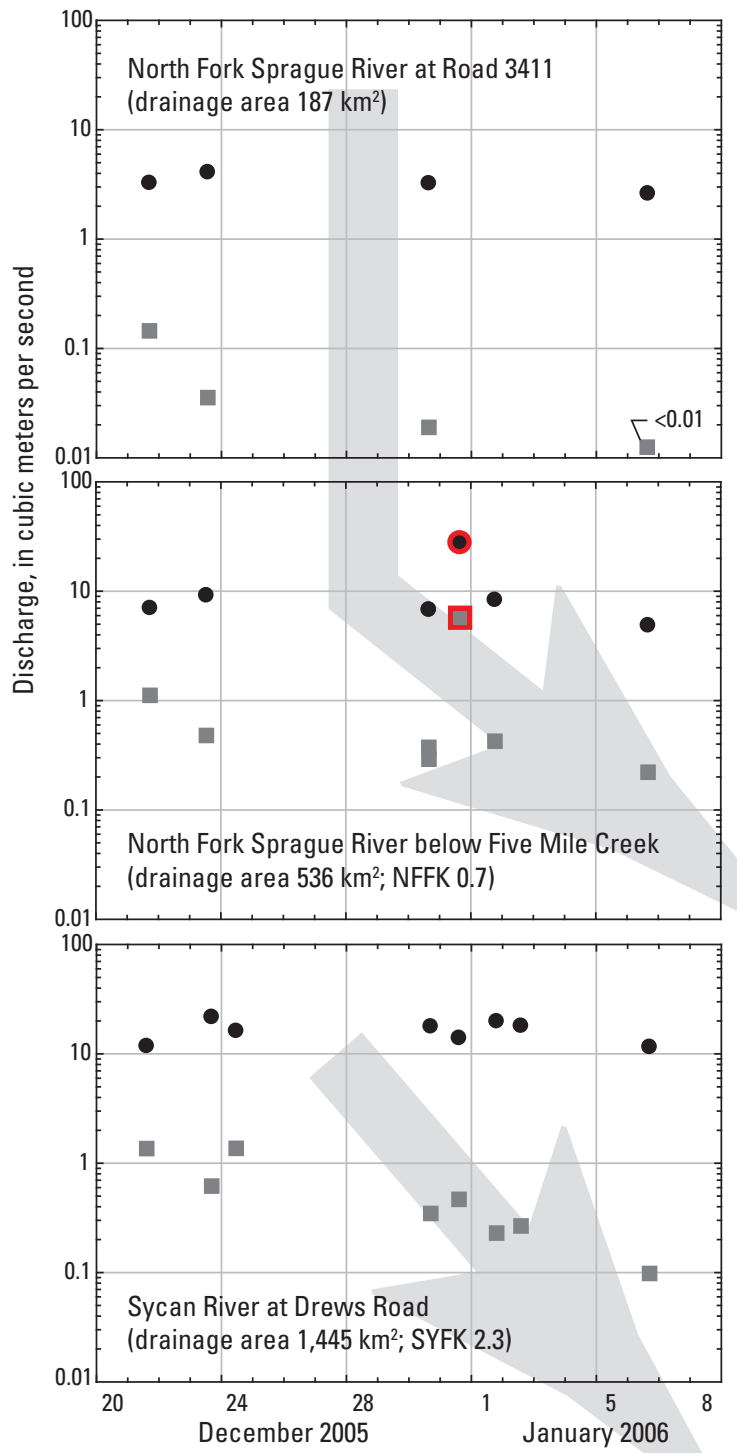

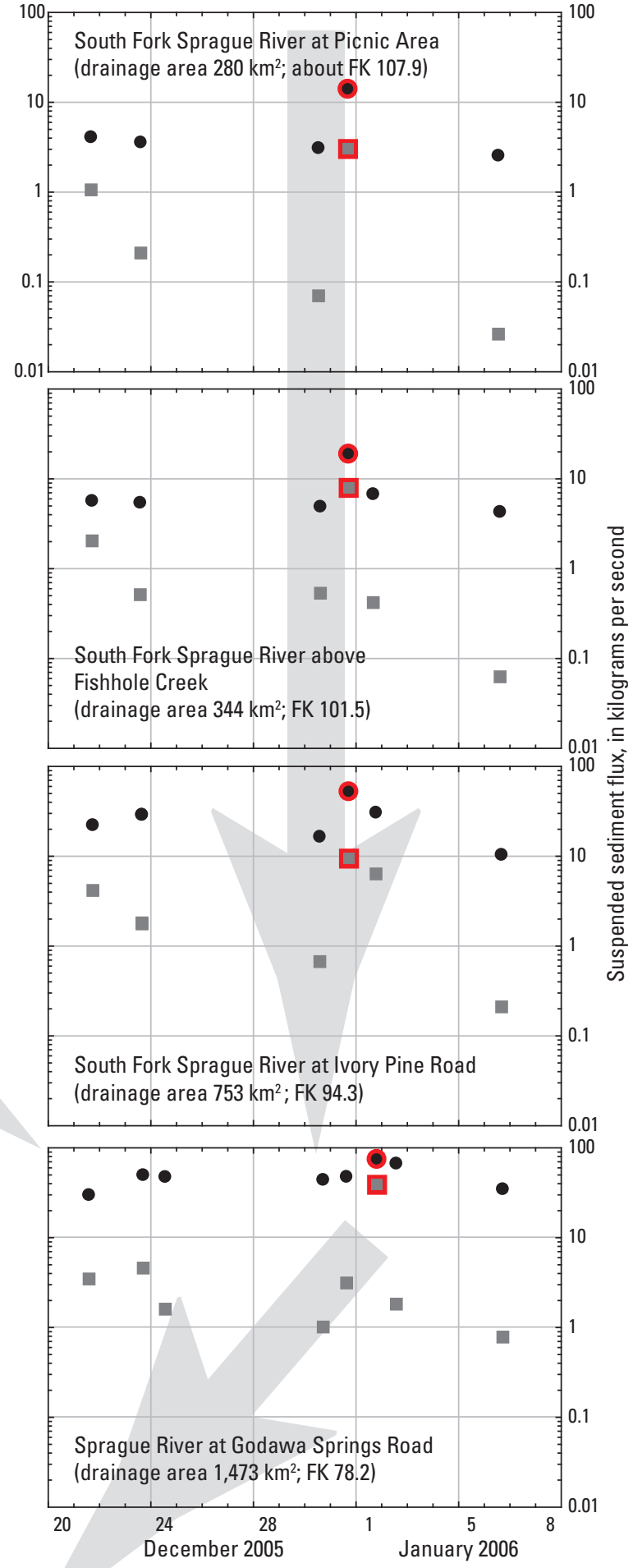

Figure 55. Discharge and suspended sediment transport between December 20, 2005 and January 7, 2006 period of high flows for seven locations in the Sprague River Basin, Oregon. Data source: Graham Mathews and Associates (2007). 


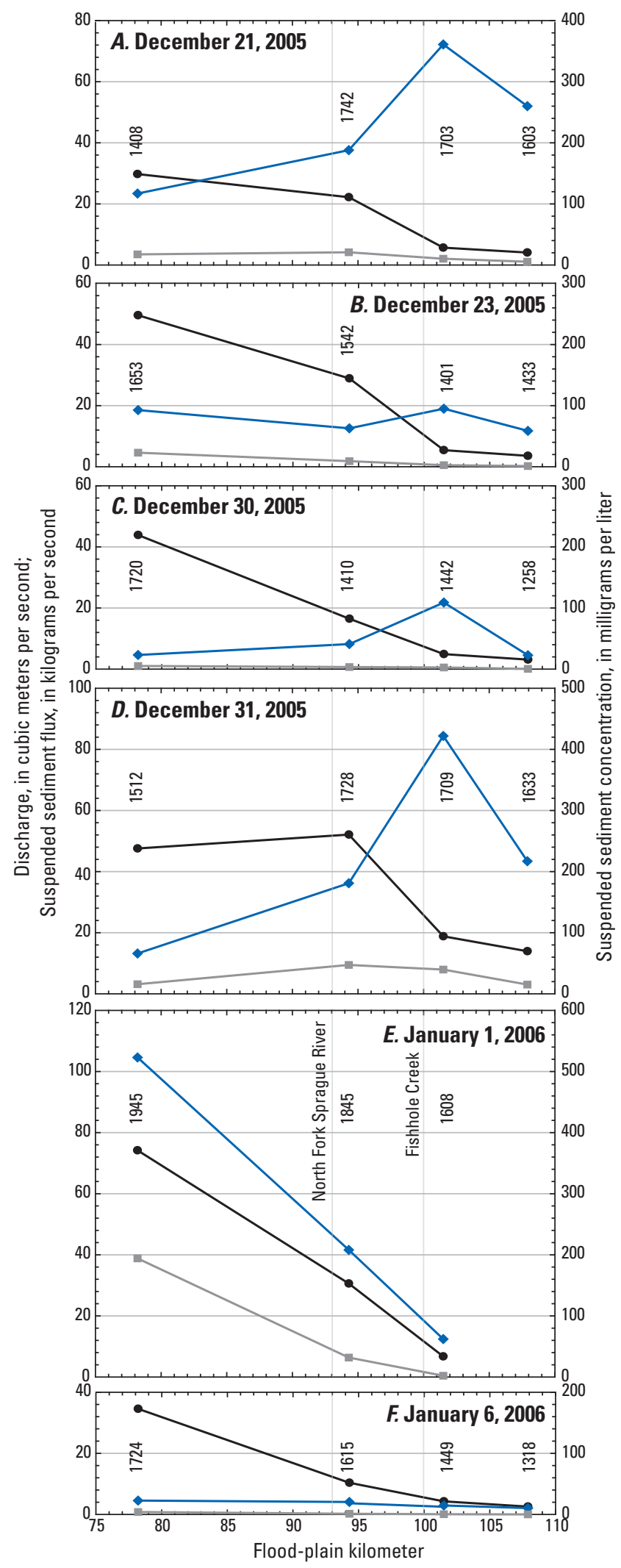

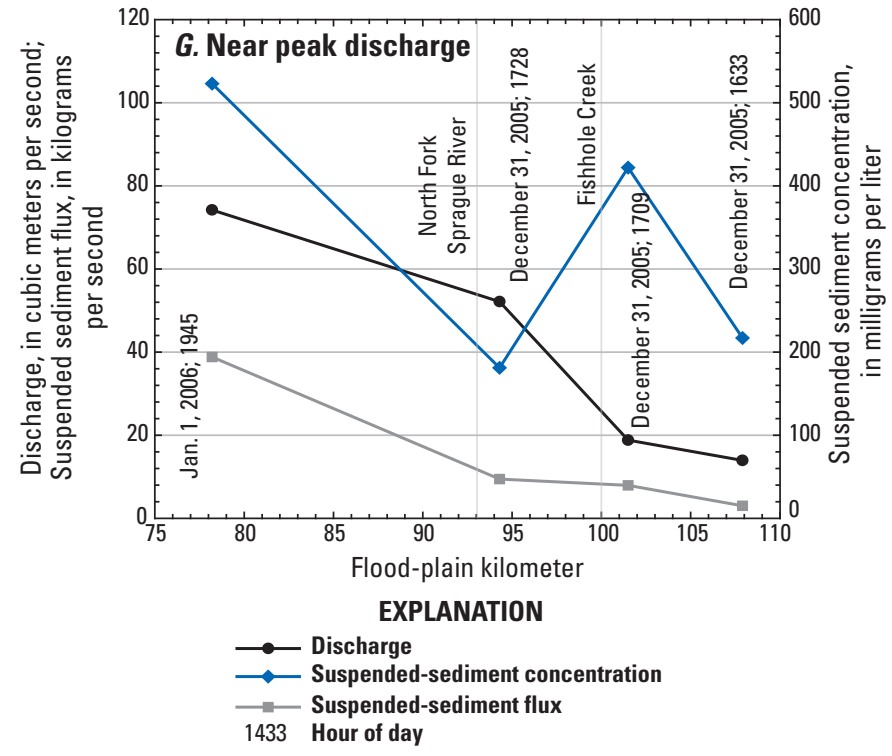

Figure 56. Longitudinal trends in discharge and suspended sediment transport for 6 days of observations $(A-F)$ and at nearpeak discharge $(G)$. Graphs were developed from data reported in Graham Mathews and Associates (2007). 
The downstream increase in sediment concentration and load must result from sediment derived from sources downstream of the North Fork Sprague River confluence with the main-stem Sprague River because the January 1, 2006, North Fork suspended-sediment load at NFFK 0.07 together with the load at South Fork Sprague River at Ivory Pine Road (FK 94.3, $0.9 \mathrm{~km}$ upstream of the North Fork Sprague River confluence) do not come close to accounting for the load measured downstream at nearly the same time on the Sprague River at Godawa Springs Road. This sediment input most likely resulted from channel and bank erosion or tributary inputs in the Upper Valley or Beatty Gap valley segments.

\section{Channel and Flood-Plain Processes}

The geomorphic mapping and historical observations, in combination with the observations and trends evident from the map and photograph analyses and synoptic survey, provide a basis for interpretation of channel and flood-plain processes. Additionally, these observations can support inferences as to how geologic conditions and human alterations have affected these processes.

\section{Channel Processes}

Channel processes are influenced broadly by basin-scale conditions of flow and sediment supply (in particular bed material) and, at the segment scale, channel slope. Therefore, attributes such as channel width, flow, and slope are strongly correlated. However, specific local morphologic characteristics and associated physical habitat conditions relate to local interactions among sediment transport, bed and bank materials, depositional processes, and lateral and vertical erosion.

\section{Sediment Transport}

Bed-material and suspended sediment transport are important channel-forming processes in the Sprague River Basin. Transport and deposition of bed material composed of sand and gravel builds bars; therefore, they are factors in building new flood-plain surfaces as well as in promoting lateral channel migration, including cutoffs and channel avulsions. The suspended load of very fine sand, silt, and clay is the dominant sediment accumulating on established flood plains deposits, therefore influencing bank erosion processes and riparian vegetation.

Measurements of suspended sediment load during 2004-2006 by Graham Mathews and Associates (2007) show that the South Fork Sprague River contributes about 60 percent of the total suspended sediment load to the Sprague River, with the North Fork Sprague River (27 percent) and Sycan River (13 percent) contributing markedly less. The overall measurement program of Graham Mathews and Associates, as well as the measurements made during the
December 31, 2005 and January 1, 2006 high flows, show that much of the suspended sediment originates in the North Fork and South Fork valley segments (figs. 55, 56). This sediment possibly is the result of lateral channel erosion, bed incision, or tributary input. The historical evidence of possible incision in the North Fork and South Fork valley segments suggests that bed incision, either within the two forks themselves or possibly by incising tributaries and irrigation ditches graded to the rivers, probably is an important factor in the increased suspended sediment loads. This sediment may result in part directly from bed erosion, but probably more significantly from enhanced channel widening within incising reaches.

Some of the suspended sediment load is deposited on flood-plain surfaces, resulting in the vertical accretion evident in all of the stratigraphic sections of post-Mazama flood plains in the study area (figs. 5, $\underline{8}, \underline{9}$ ). Downstream of the confluence of the North Fork and South Fork Sprague Rivers, the sequence of high flows in WY 2006 deposited as much as $20 \mathrm{~cm}$ of sediment (median thickness $4 \mathrm{~cm}$ ), presumably composed of suspended sediment load onto flood-plain surfaces as high as $1.5 \mathrm{~m}$ higher than the low-flow water surface. This deposition might be an important factor in the overall sediment budget. Suspended sediment load estimates by Graham Mathews and Associates (2007) indicate that the load passing the measurement site near the basin outlet near Chiloquin was only 63 percent of the combined load delivered by the North Fork and South Fork Sprague Rivers, and the Sycan River between November 2, 2005 and January 6, 2006. This indicates substantial net deposition along the main-stem Sprague River, probably on floodplains. The presence of cesium-137 $\left(\mathrm{Cs}^{137}\right)$ in the near-surface floodplain stratigraphy (as much as $20 \mathrm{~cm}$ below the land surface; appendix D) also indicates significant post-1950 deposition on many flood-plain surfaces.

Flood-plain deposition requires flood-plain inundation. During the 2006 flood, much of the flood plain was inundated along the main-stem Sprague River as well as along at least the lower North Fork Sprague River (figs. 9, $\underline{52}, \underline{54}$ ). However, if the frequency or extent of flood-plain inundation is decreased by channel incision, levee construction, or reduced formation of low flood-plain surfaces (mainly from channel migration), downstream sediment loads may increase because of the combined effects of less overbank deposition and greater in-channel flow velocities accelerating bank erosion and increasing transport capacity.

Bed-material transport is evident by the bars along the length of the study reach (figs. 15, 18, $\underline{\text { 39) }}$ ), but little is known about actual transport rates. Graham Mathews and Associates (2007) measured bedload 14 times among 5 locations during WYs 2004 and 2005. From six measurements of the Sycan River at Drews Road (SYFK 2.2), Graham Mathews and Associates estimated that bedload constituted about 30 percent of the total sediment load, a value similar to the 35 percent estimated from five measurements on the South Fork Sprague River picnic area just upstream of the study area at FK 107.6. 
Both of these sites are steeper than most of the study area, and bed-material transport rates likely are lower and constitute a smaller fraction of the total sediment load in the lower-gradient main-stem valley segments than at these sites.

The reaches of greatest bed-material transport are those where both transport capacity (chiefly a function of channel slope and flow depth) and bed-material supply are high. These conditions can be inferred in part from the spatial and temporal distribution of bars. Bars are more abundant where the South Fork and North Fork Sprague Rivers emerge onto the alluvial valleys from the uplands surrounding the study area into the South Fork and North Fork valley segments. However, the greatest frequency and area of bars is near the confluence of the Sprague River with the Sycan River in the Beatty-Sycan and Council Butte valley segments (figs. 18, 39), pointing to the Sycan River as a key source of bed material (Hughes and others, 2009). Bars also are abundant in the Buttes of the Gods segment. The scarcity of bars in the Chiloquin Canyon and Braymill segments is the consequence of the greater slope and confinement of these reaches, which results in most bed-material sediment delivered from the low-gradient and unconfined reaches upstream being transported efficiently through these segments.

The relatively high volume of bed material associated with the Lower Sycan valley segment compared to the North Fork and, even more so, the South Fork valley segments (figs. 18, 39) owes to the much greater sand supply in the Sycan River. The much thicker accumulation of Mazama pumice in the Sycan River watershed compared to the other watersheds (Sherrod and Pickthorn, 1992), in conjunction with locally eroding banks of Sycan flood deposits (fig. 7), provides abundant sand-size pumiceous material to the Sycan River. The North Fork Sprague River and South Fork Sprague River drainages were blanketed with respectively thinner accumulations of Mazama tephra - particularly sand-size accumulations. Therefore, these drainages have had less bed-material transport during the late Holocene. As a result, bar frequency is less upstream of the Sprague River confluence with the Sycan River, and bars are very sparse upstream on the South Fork Sprague River. During late Holocene and historical periods of wetland soil formation, evident in the stratigraphy of both the North Fork (fig. 9) and South Fork (fig. 8) Sprague River segments, there likely was little bed-material transport in these valley segments.

The much greater bar frequency mapped from the 1968 aerial photographs compared to the 1940 and 2000 aerial photographs indicates the importance of large flows in transporting bed material. In this case, the December 26, 1964, flood almost certainly is responsible for significant bed-material transport and resulting bar formation and expansion, similar to but to a greater degree than the depositional patterns documented by the survey of effects of the 2006 high flows. The relatively greater importance of high flows in transporting bedload is consistent with the few measurements by Graham Mathews and Associates (2007) and the observations from more systematic bed-material transport measurements and modeling studies for other western Oregon rivers (Wallick and others, 2010, 2011).

Overall bed-material transport rates likely are low in the Sprague River. The absence of continuous sand and gravel bed-material cover of the channel bottom (all valley segments have significant reaches of channel bottom composed of consolidated silt and clay) indicates that bed-material supply is exceeded by transport capacity at decadal to century time scales, despite low transport capacities in most reaches because of low channel gradients. Bed-material supply is limited in the Sprague River Basin because, like in the Deschutes River Basin to the north, the basin geology of mainly volcanic rocks does not produce substantial bed material (O'Connor, and others, 2003b). Given the composition of modern and late Holocene bed-material deposits, pumiceous sand from the 7,700 cal yr BP Mazama eruption, derived either from upstream parts of the basin or from the reworking of flood-plain deposits, continues to be a major source of bed material. The low supply and transport rates partly explain the overall scarcity of bars as well as the low channel migration rates of the main-stem Sprague River.

\section{Bar Building}

In addition to providing an index to bed-material transport rates, bar deposition affects channel and flood-plain morphology by promoting channel migration and by providing a foundation for young and low flood-plain surfaces. Bare bars also provide germination sites for riparian vegetation, particularly rushes, sedges, and riparian grasses. Most of the bed material forming bars is pumiceous sand, mainly derived from the Sycan River Basin but also, to a lesser degree, from the North Fork and South Fork Sprague Rivers. An unknown but probably sizeable fraction of modern bar material is from the reworking of older (but post-Mazama) flood-plain deposits, including the Sycan flood deposits, by lateral erosion and channel migration.

Where visible in stratigraphic sections and during the 2006 survey, dipping beds of sandy material indicate that bars grow laterally. In most situations, bar growth is in the form of point bars, but also locally as mid-channel islands and accumulations in flow separation zones formed by woody debris accumulations, natural and artificial channel obstructions, and channel bifurcations. Stratigraphic sections along the Sycan River and North Fork Sprague River (figs. 11, 14) show that these point bars gradually evolve into floodplain surfaces, with bedding indicating a transition from lateral to vertical accretion.

Bars are a factor promoting bank erosion and lateral migration. Bars deposited on the inside of channel bends and in mid-channel force flow to the outside of bends and channel margins, enhancing bank erosion and lateral migration. Bars are sparse in the Sprague River study area compared to many alluvial rivers; nevertheless, their frequency correlates 
with migration rates (fig. 46A). This finding also is consistent with the evident transformation recorded by the stratigraphy of the fluvial system at the time of the Mazama eruption from one of low-energy and possibly locally unchanneled floodplains and wetlands to a connected fluvial system consisting of channels migrating across the flood plain.

\section{Bank Erosion}

In conjunction with bar building and channel migration, bank erosion is a ubiquitous process in the Sprague River study area. Judging from the sediment transport measurements, bank and channel erosion, especially in the Upper Valley and South Fork valley segments, is a significant contributor to suspended sediment loads. Bank erosion is a complex process (Simon and others, 1999) involving fluvial processes of direct entrainment and undercutting, gravity-caused mass movements and raveling, and disturbances such as trampling by animals (including livestock) and effects of debris, waves, and vehicular traffic. The relative effectiveness of different processes is affected by the nature of the bank materials, bank and channel geometry, flow conditions and vegetation (Florsheim and others, 2008).

Bank erosion is most evident in the study area in the form of vertical banks, commonly flanked at their base with down-dropped blocks of flood-plain sediment (fig. 57). Although approaches are available for quantitatively assessing bank erosion, especially for low-energy and fine-grained fluvial systems such as the Sprague River (Simon and others, 1999; Pollen-Bankhead and Simon, 2008), our observations were qualitative, drawn from inspections of banks during the course of stratigraphic analyses and the survey of the effects of the WY 2006 high flows.

Banks in the Sprague River study area are mostly formed in young, fine-grained flood-plain deposits, particularly in the unconfined reaches. For example, the Kamkaun Spring, Buttes of the Gods, Council Butte, Beatty-Sycan, Upper Valley, South Fork, and North Fork valley segments all have more than 80 percent of their year 2000 channels wholly contained within the geomorphic flood plain (fig. 16), which mostly post-dates the Mazama eruption of 7,700 cal yr BP. The case for the Lower Sycan valley segment would be similar except that the channel is within $10 \mathrm{~m}$ of the Sycan flood deposits for 23 percent of its length.

The different bank materials apparently correlate with different mechanisms and consequences of bank erosion. The young flood-plain deposits - with their typical stratigraphy of unconsolidated pumiceous sand overlain by more cohesive very-fine sand, silt, and clay locally strengthened by dense root networks - are subject to undercutting, especially on the outside of bends where boundary shear stress is greatest (Dietrich and others, 1979). In many cases, such undercutting during WY 2006 promoted down dropping of cohesive blocks of overlying flood plain, resulting in stepped bank forms. These fallen blocks, which appear to have moved by toppling and slip failure, provide substrate for colonization by

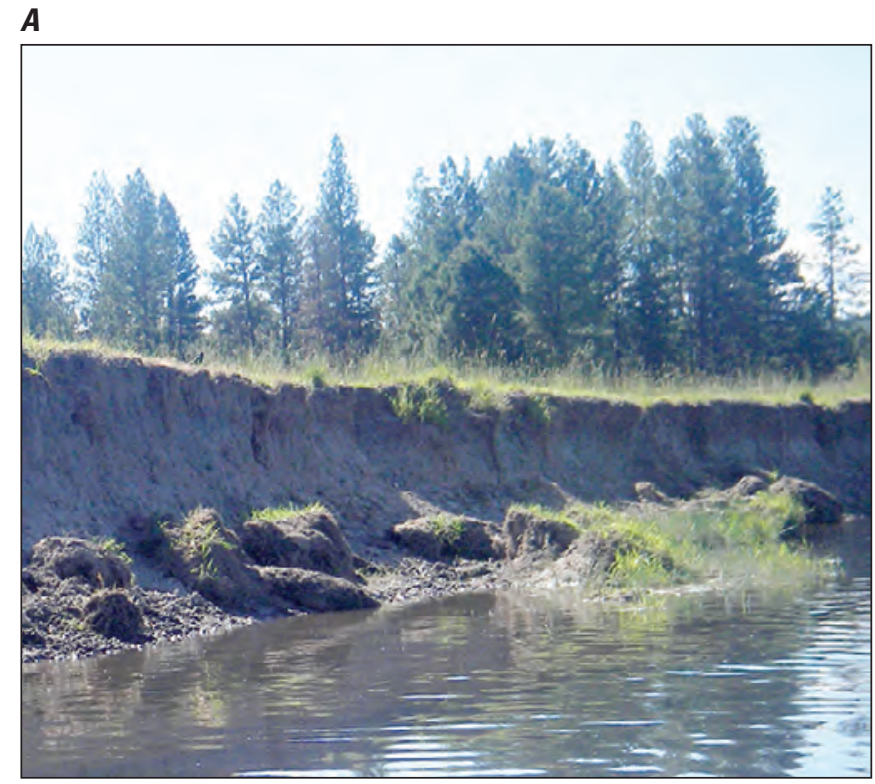

\section{B}

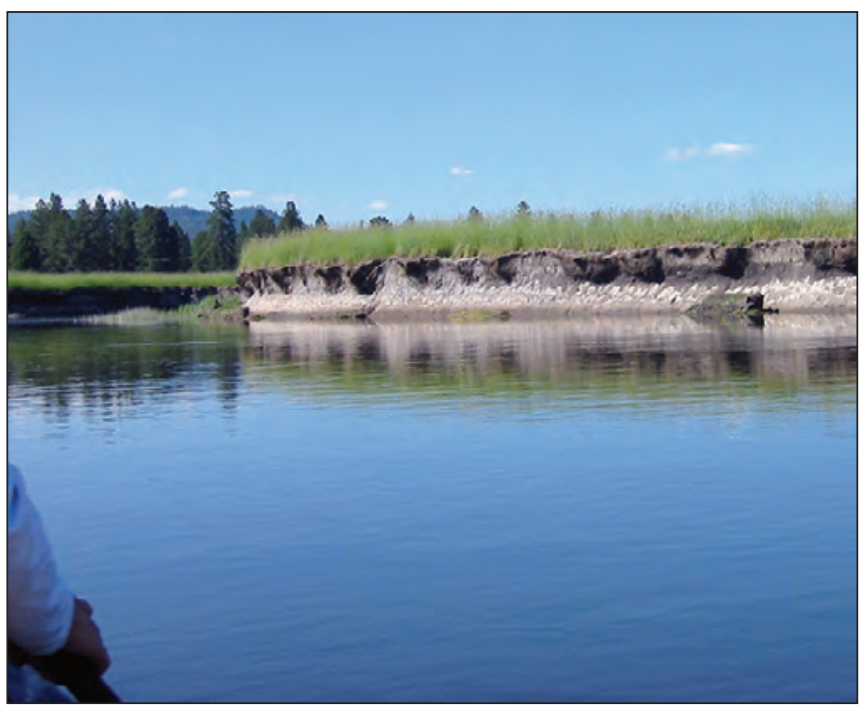

Figure 57. Examples of bank erosion with down-dropped blocks of flood-plain deposits, including $(A)$ left-bank erosion in $\mathrm{S}^{\prime}$ Ocholis Canyon valley segment (June 29, 2005), and (B) right-bank erosion in Kamkaun Spring valley segment (June 25, 2006), main-stem Sprague River, Oregon. Photographs taken by J.E. O'Connor, U.S. Geological Survey.

saturation-tolerant species (fig. 57A). The Sycan River flood plain, with its more prevalent pumiceous sands and overall greater channel slopes than other valley segments, appears to be especially susceptible to bank erosion. Young flood-plain deposits in the South Fork valley segment do not have thick pumiceous sands at the base of their stratigraphic sections, perhaps inhibiting bank erosion by undercutting and mass wasting, although the sediment transport analyses indicate that this segment is a major contributor of suspended sediment. 
Bank erosion where the channel impinges on older surfaces is less common because contact between the active channel and older surfaces is rare in most reaches (fig. 16). In the few locations where the present channel is eroding edges of pre-Mazama terraces and fans, erosion rates appear to be slow with less undercutting because of the more consolidated character of sand and gravel at the base of these stratigraphic sections compared to the pumiceous sand at the base of the late Holocene flood-plain deposits. Tall raw banks formed in older materials locally extend along the channel for distances exceeding tens of meters. These banks appear to erode slowly, with freeze-thaw, desiccation, and biogenic disturbance possibly being the main processes loosening bank materials, thereby facilitating fluvial entrainment and helping to maintain unvegetated faces.

The Sycan River has a distinctive situation that locally promotes bank erosion. Within the Lower Sycan valley segment, the channel abuts the Sycan flood deposits along about 23 percent of its length (fig. 16). Here, the bank stratigraphy is composed of coarse and granular pumiceous sand overlying compact silt and clay, with the contact between the strata as much as $2.5 \mathrm{~m}$ above the low-flow water surface (figs. 5, 7). Whereas the pre-Mazama fine-grained flood-plain deposits resist erosion, the loose pumiceous sands above are exceptionally erodible, especially where vegetative cover is disturbed. Erosion is enhanced by water seepage concentrated at the basal contact of the granular sand and the underlying and less permeable silt and clay. This seepage locally conveys the overlying sand to the channel edge. In places, this seepage appears augmented by irrigation of the Sycan flood deposits.

Although bank erosion can increase sediment loads, cause property and infrastructure loss, and perhaps locally adversely affect aquatic and riparian habitat conditions, bank erosion also is a key process for maintaining channel migration and other key ecologic processes (Florsheim and others, 2008). Bank erosion probably is a significant source of bed material for the Sprague River and North Fork Sprague River, particularly by providing a supply of the pumiceous sand, which is an important bar-building material. Locally, bank erosion also creates diverse bank and channel-margin conditions, especially where blocks of flood-plain sediment have down-dropped to low-water levels. Together these features create variable hydraulic environments and provide many of the low, near-channel surfaces for colonization by aquatic and riparian flora (Hughes and Leeseberg, 2009).

\section{Incision}

The common cut banks in the Sprague River study area are cited as an indicator of recent channel incision (Connelly and Lyons, 2007; Rabe and Colonje, 2009). However, evidence of historical channel lowering primarily is restricted to the upstream parts of the study area, including the South Fork, and possibly parts of the North Fork, Upper Valley, and
Beatty Gap valley segments. No local observations document the processes and specific timing, but in these locations, incision probably has proceeded by upstream migration of knickpoints, as is commonly the case for channels with fine-grained or cohesive beds (Simon and Rinaldi, 2006). Like many incised streams (Cooke and Reeves, 1976; Schumm, 1999), some of these knickpoints may have been initiated by diversion or diking leading to flow concentration, or by clearing or removal of wood accumulations, including beaver dams. For the South Fork Sprague River, particularly for the straightened section with levees between FK 97.0 and 101.1, channel incision probably was partly caused by direct excavation of materials from the channel for levee construction. In-channel excavation, documented by historical observations in the Kamkaun Spring valley segment (Greg Harris, oral commun., September 13, 2007), may be a factor in other local areas of possible historical channel incision in the Upper Valley and Council Butte valley segments.

The irregular channel profile along the South Fork Sprague River upstream of the diversion structure at the Campbell Road Bridge at FK 101.4 (fig. 32) may represent active channel erosion. Migrating knickpoints in this upper part of the South Fork valley segment would be consistent with the higher suspended sediment loads derived from this reach during the 2006 high flow (fig. 56). Enhanced sediment loads could result from direct sediment introduction to the flow either as the knickpoint erodes or from incision of diversion channels and bank crevasses connected to the lowering channel.

Channel incision can be mitigated locally by gradecontrol structures as well as natural processes such as beaver activity and in-channel wood accumulation. The existing diversions on the South Fork Sprague River at FKs 100.0 and 101.5, as well as the shorter structure on the North Fork Sprague River at NFFK 1.1 and the in-channel rock placement at NFFK 5.2, are all currently protecting upstream reaches from incision (fig. 32). Judging from overall profile trends, removal of these structures, either planned or by flood, without mitigating grade protection measures, likely would trigger incision extending perhaps several kilometers upstream.

\section{Channel Substrate}

Channel substrate varies across the study area, ranging from coarse boulder material in the steep and confined Chiloquin Canyon and Coyote Bucket valley segments to indurated silt and clay where the channel is flowing directly on older Tertiary lacustrine sediment. Additionally, most valley segments have patchy to nearly continuous sand and gravel on the channel bottom and margins. Placed rock marks some fords and former bridge crossings, as well as channel restoration and bank protection sites. 
The coarse cobble and boulder substrate in the Chiloquin Canyon and Coyote Bucket valley segments and other locations where the channel impinges on or is near bedrock probably is rarely mobilized. Stable rock accumulations locally may promote erosion and deposition of other substrate materials by changing local hydraulic conditions. Placed rock, however, may be susceptible to displacement in locations of bank erosion or channel incision.

Indurated silt and clay substrate is common in several valley segments. During the 2006 synoptic survey, we noted extensive reaches of this substrate in the Buttes of the Gods and the Kamkaun Spring valley segments. Indurated silt and clay substrate also is common in the lower part of the Lower Sycan valley segment (fig. 34), and was the main substrate visible at road crossings of the South Fork Sprague River in the South Fork valley segment. Impenetrable silt and clay marked the bottom of most augering attempts in the Buttes of the Gods and Kamkaun Spring valley segments (figs. 12, 13). In the Lower Sycan, Buttes of the Gods, and Kamkaun Spring valley segments, this indurated substrate is inferred to be Tertiary lacustrine sediment on the basis of the pervasive jointing, similar to that in roadcut exposures in the area. However, in some places (particularly in the Upper Valley and South Fork valley segments), the indurated silt and clay substrates may be late Quaternary low-energy flood-plain and wetland deposits.

The silt and clay substrate erodes into forms commonly associated with soft bedrock channels (Richardson and Carling, 2005), including flutes, furrows, and potholes. Some furrows, particularly in recent meander cutoffs, have low-flow water depths exceeding $2 \mathrm{~m}$. These erosional features seem to be stratigraphically and structurally controlled, with plucking and erosion taking advantage of horizontal weaknesses associated with softer strata and vertical zones of weakness caused by joints. At low flow in the Buttes of the Gods valley segment, several small and short water-surface drops result from spill over ledges formed of resistant beds.

This hard substrate probably inhibits channel incision in several of the valley segments where it forms much of the channel bottom. Where incision has occurred or is ongoing, as is probably the case for the South Fork valley segment, the resistant silt and clay form persistent and slow-migrating knickpoints or short reaches of high channel slope.

In most valley segments, patchy-to-continuous sand and gravel (and in places, soft mud) locally cover the indurated silt and clay substrates. This sediment represents current bed-material supply and transport conditions. These materials generally are loose, and the sand-size component is dominated by pumice grains. Gravel, typically with a diameter of less than $2 \mathrm{~cm}$, locally is common along the channel thalweg in several valley segments, and is mostly volcanic clasts. In the steeper upstream parts of the Lower Sycan, North Fork, and South Fork valley segments, gravel and cobble channel bottoms and marginal bars are more common, in places forming continuous alluvial channels extending for several kilometers. In some reaches, particularly in the Lower Sycan and North Fork valley segments, sand and gravel bed material is organized into pool and riffle sequences (fig. 33). However, the patchiness of alluvial cover in the Sprague River channel network indicates that overall bed-material supply does not match the transport capacity.

The augering transects, stratigraphic studies, and observations from the 2006 survey indicate that bed material locally accumulates in areas of reduced flow velocity during high flows, particularly downstream of obstructions, on the inside of channel bends, and in entrances of side channels. In addition to mid-channel and point bars, such deposition locally creates sandy bars at the entrance of side channels and can promote flow diversion into nascent meander cutoffs.

Spring channels, connecting springs to the main channel through the geomorphic flood plain, typically have well-sorted pumiceous sand bottoms. For these channels, it appears that spring flow is sufficient to mobilize silt and clay, leaving wellsorted sand. In situations where river channel migration or avulsions result in the formation of new spring channels, these new channels also will likely evolve, through time, to have well-sorted sandy beds under conditions of relatively constant spring discharge.

Maintaining an alluvial cover on the channel bottom depends partly on maintaining a supply of bed material. Over millennial time scales, as the supply of pumice sand diminishes from the upper parts of the basin, the importance of bank erosion and reworking of flood-plain accumulations of sand and gravel will grow as a source of sand and gravel channel substrate.

\section{Flood-Plain Processes}

The overall observations of historical and modern flood-plain conditions and trends, as well as inferences regarding important channel processes, provide a framework for understanding the major flood-plain forming processes. These processes include the mechanisms and consequences of lateral channel movement across the flood plain - in the Sprague River study area, meander growth counteracted by meander cutoff and channel avulsion - as well as the overbank depositional and erosional processes by which flood-plain surfaces are built, eroded, and modified.

\section{Meander Growth}

Meander growth strongly contributes to flood-plain morphology in the Sprague River study area. Meander enlargement provides opportunities for channel cutoffs and meander abandonment that result in the overall native floodplain morphology of abandoned channels (and associated ponded water and side-channel environments) and multi-level, flood-plain surfaces. 
On the Sprague River, meander growth is by the tightly coupled processes of bar formation and lateral erosion. Judging from the presence of measureable migration rates and bar presence in all valley segments, these processes appear important to some degree for the entire study area. It is primarily the unconfined (either by valley margins or levees) segments, however, where meander loops can enlarge to promote high sinuosity (fig. 38).

Bar morphology also can indicate patterns of meander growth. In particular, the orientation of scroll bars - concentric ridges developed on a point bar surface through time as it evolves (Lobeck, 1939; Hickin 1974)—support interpretations of the direction and type of channel movement. Hooke (1997) identified five major types of bar movement: (1) downstream translation, (2) upstream translation, (3) expansion (growing toward the flood-plain margin), (4) rotation, and (5) development of a compound or double-headed meander. Scroll bars are more evident in the wide valley segments. The dominant types of meander movement indicated by scroll bars in the Kamkaun Spring, Buttes of the Gods, Council Butte, and Sycan-Beatty valley segments are downstream translation (fig. 12) and expansion (fig. 54), although some bars show evidence of upstream translation and development of compound meanders.

The slow rates of meander growth for the Sprague River and its major tributaries owe to the low overall bedmaterial transport rates and the low stream power. Channel confinement and slope are local factors also apparently exerting control on migration rates at the segment scale. The confined canyon segments and the South Fork valley segment confined by levees all have low migration rates compared to the unconfined valley segments (fig. 45). Channel slope is positively correlated to migration rates (fig. $46 B$ ), except for the steeper but closely confined Chiloquin Canyon segment, consistent with observations that stream power (which is directly proportional to slope) is correlated to bank erosion and channel migration (Nanson and Hickin, 1986; Richard and others, 2005).

\section{Cutoff and Avulsion Processes}

Cutoffs and avulsions counteract meander growth by isolating meander loops from the main channel. Cutoffs and channel avulsions typically reduce local sinuosity and increase local channel slope. They also leave a suite of backwater and side-channel environments, thereby providing important aquatic and riparian habitats.

A cutoff is the breaching of a meander bend at or near its base. They typically form by one of two processes: (1) Neck cutoffs, which result from bank erosion, narrowing the neck until the channel breaches between the upstream and downstream meander limbs; and (2) Chute cutoffs, which result from new channels shortcutting between upstream and downstream meander bends, commonly without narrowing of the meander base (Thomas and Goudie, 2000) (figs. 40A, $\underline{B}$ ).
Prolonged meander growth inevitably leads to meander cutoff as the enlarging meanders intersect. Consequently, sinuosity commonly attains a stable level maintained dynamically by the concomitant processes of meander growth and cutoffs (Hooke, 2003).

An avulsion refers to the sudden movement of the channel to a new location on the flood plain without substantially eroding or reforming the intervening flood-plain surface. Avulsions may result in anabranches that bypass several meander loops, forming new primary or secondary channels (fig. 40C). The new location may be a new channel incised into the flood plain or an older channel that is re-occupied. In some locations, chutes or neck cutoffs may involve secondary channels formed by avulsions (fig. 40A).

Avulsions and chute cutoffs require overbank flow. Lateral migration and resulting neck cutoffs may result from flows confined to the channel (Hooke, 1997). After a secondary channel forms, channel infilling and bar growth in the older channel may accelerate diversion of primary flow into the newly formed channel, transforming the older channel into low flood plain and backwater areas (fig. 12). In some cases, however, multiple channels may convey flow for several decades.

The main mechanism for meander abandonment in the Sprague River study area is chute cutoff, accounting for 42 of the 63 instances of observed meander abandonment for which the process could be determined (table 8 ). Only 12 avulsions were evident, but their effects are more significant than individual chute cutoffs because typically they result in abandonment of many meander loops. Only nine examples of neck cutoff were evident from the historical aerial photograph and map analysis. The relative rate of cutoff and avulsion processes is consistent with the overall geomorphic regime of frequent overbank flooding (which facilitates chute cutoffs and avulsions) and slow migration rates (which reduces the occurrence of neck cutoffs).

A process possibly promoting chute cutoffs in the Sprague River Basin is the formation of ice jams. Residents report that the Sprague River is subject to ice-flow jams that lead to backwater and overbank flow. Small incised channels on the flood-plain surface that drain from meander interiors to the main channel (fig. 58) may have been formed by overbank flow returning to the main channel during ice-jam floods. These may serve as pilot channels that initiate chute cutoffs, as has been observed for other rivers (Smith and Pearce, 2002; Prowse and Culp, 2003).

Chute cutoffs in the Sprague River Basin also may be promoted by channel and flood-plain modifications imposed by levees and railroad grades. This mechanism is evident in the Council Butte valley segment, where incipient chutes appear to be forming along levees (fig. 40B), where overbank flow depth (and erosive power) has been enhanced by confinement and where new channel formation may be taking advantage of areas of flood-plain excavation for levee 

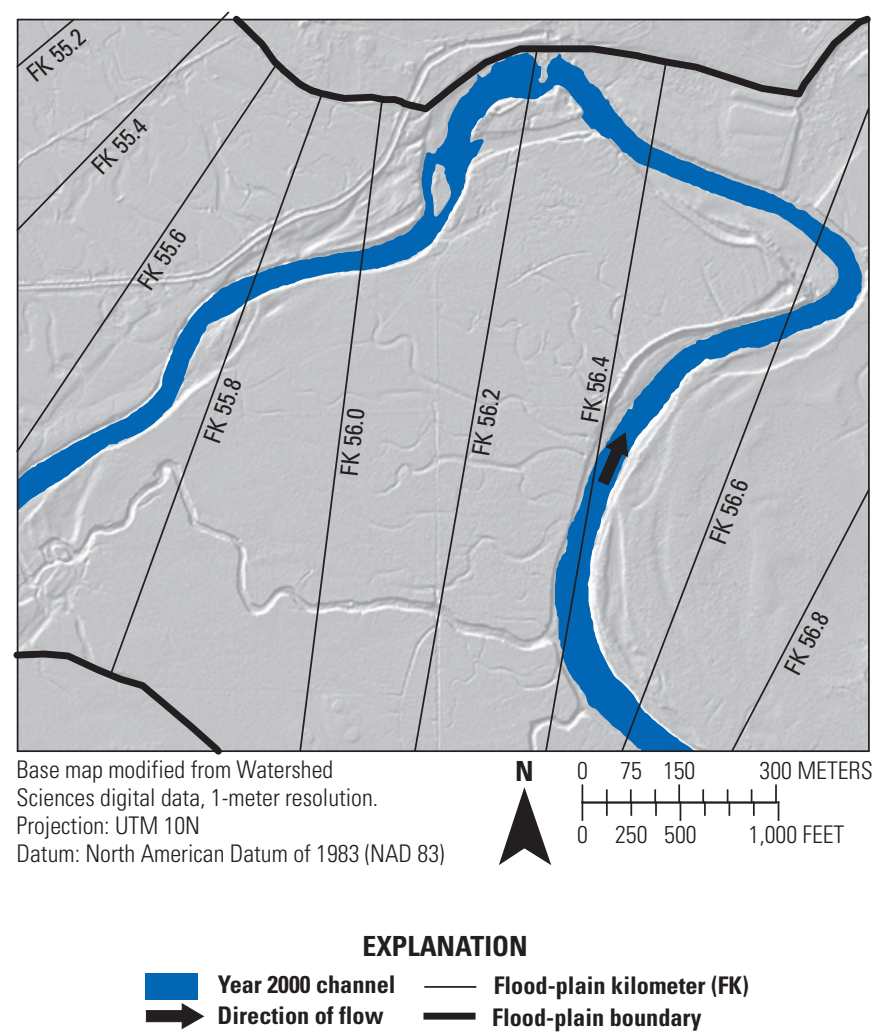

Figure 58. Channels, possibly caused by ice jams, formed on Sprague River flood plain, Oregon. The narrow continuous channel spanning the meander bend eventually may enlarge, resulting in a meander cutoff.

construction. In general, flow confinement will increase the likelihood of cutoffs, as will ground-disturbing activities such as vehicle tracks or animal paths that disrupt flood-plain vegetative cover and thereby facilitate new channel formation.

Some avulsions may result from processes similar to those for chute cutoffs, but with the new channels bypassing many meander loops. In particular, the 12 avulsions since 1940 appear to be of this type (fig. 40A). These avulsions generally are short, cutting off only two or three meander loops. Contrasting with these are the longer anabranches near the Sycan River confluence (fig. 40C). Long anabranches are typically associated with aggrading rivers, particularly those with high sediment loads (Slingerland and Smith, 2004). The long anabranches in the Council Butte near the Sycan River confluence have been stable since at least 1940 and partly may be relic features related to aggradation of the lower Sycan River and parts of the Sprague River after the Mazama eruption and the Sycan flood.

The 35 cutoffs and avulsions in the 1940-68 period exceed the 28 instances in the ensuing 37 years through 2005. The significant overbank flow during the 1964 flood probably was a contributing factor to this period of significant channel change. The extensive levee building and diking in the 1940-1968 period may have accelerated or promoted cutoff formation.

At channel avulsions and meander cutoffs, the resulting abandoned channels typically become backwater or secondary channels, oxbow lakes, and wetland areas. These channels eventually fill with sediment and organic materials, depending on the nature of the connection with the primary channel. For isolated abandoned channels, the topographic channel form and resulting oxbow lakes or seasonally wet areas may persist for millennia before filling with overbank deposits. For connected abandoned channels, infilling may be much more rapid, as is the case for the 1940 channel at FK 48.2 (fig. 12).

\section{Flood-Plain Building}

Together, all of these processes of channel movement and sediment erosion, deposition, and transport create the geomorphic flood plains of the study area with their diverse forms, including oxbows, scroll bars, overflow channels, and flood-plain surfaces of varied altitudes. In addition to providing sources of bedload and suspended sediment load for building downstream bars and flood-plain surfaces, channel migration provides new surfaces for flood-plain formation. In many areas of lateral migration, such surfaces typically begin as low-altitude bars formed of laterally and obliquely accreted bed material (fig. 15). In areas of more rapid channel migration and high bed-material supply, scroll bars may form in conjunction with lateral accretion. As the surfaces grow and become vegetated, vertical accretion becomes dominant. In most situations, rates of vertical growth gradually diminish as surfaces accumulate material and grow taller and as the active channel moves farther away. The highest flood-plain surfaces may accumulate sediment only during exceptional floods.

The pattern of flood-plain deposition can change if controlling factors vary. Most broadly, flood-plain deposition is affected by basin and climate factors that affect the frequency, magnitude, and duration of flooding. Channel migration, incision, and aggradation locally can change the frequency of overbank flooding and deposition. Local land use also can affect flood-plain deposition by changing the depth, velocity, and sediment concentration of overbank flows. A hint of such changes is provided by the stratigraphy of the geomorphic flood-plain, which in many cases shows coarser deposits near the top (iggs. 8, 9), indicating higher velocity flows associated with overbank deposition. Plausible explanations for this given the current understanding of changing basin and flood-plain conditions include (1) confinement (and resulting acceleration) of flow by levees and embankments, and (2) decreased surface roughness (by smoothing and vegetation removal), which also increases local flow velocities. 


\section{Geologic Controls and Legacy}

As with many fluvial systems, geologic controls and past events strongly influence channel and flood plain processes in the Sprague River system. At the broad scale, the valley segments and their morphologies represent tectonics and volcanism of the last several million years. The widespread volcanic rocks and Tertiary lacustrine sediment in intervening basins result in relatively low quantities of sand-to-gravel size bed material available for fluvial transport, leading to a general condition of supply-limited fluvial systems flowing on or close to bedrock, even in the alluvial valleys of the study area. In places where channels flow directly on Tertiary lacustrine sediment, the potential for channel incision is limited. The North Fork, Upper Valley, and South Fork valley segments all appear to be within a basin of thicker alluvial fill than other valley segments, perhaps making these segments more susceptible to channel incision.

The valley bottoms in most valley segments are bounded partly by alluvial fans and terraces deposited during the Quaternary. Although these features locally confine the flood plain and form tall banks, they probably provide little sediment to the modern rivers.

The Mazama eruption of 7,700 cal yr BP probably has been the most important geologic event affecting modern flood-plain and channel conditions. Flood-plain stratigraphy and morphology, bar distribution, and the deposits of the 2006 high flows all show the major role of pumiceous sand derived from that eruption in controlling channel migration and floodplain processes for the Sprague River and its major tributaries, mainly by enhancing bar deposition and channel movement. The historical condition of the South Fork Sprague Riverextensive wetlands flanking a poorly defined channelprobably is similar to what much of the Sprague River was like before the eruption. Because the Sycan River was the most affected by the Mazama eruption, including the ensuing Sycan flood, this tributary responded most dynamically, with many episodes of flood-plain formation and erosion over the last several thousand years (Lind, 2009). Judging from the overall distribution of bars, the Sycan River, and, to a lesser extent, the North Fork Sprague River, continue to be major sources of bed material to the Sprague River fluvial system. The many anabranches in the Council Buttes valley segment downstream of the confluence of the Sprague River with the Sycan River (fig. 40C) also may represent bed-material deposition and resulting channel avulsions.

In the absence of additional disturbance or substantial change in basin conditions, the long-term trajectory of the Sprague River and its major tributaries would likely be reversion back to pre-Mazama characteristics as the supply of sandy bed material decreases. The active channel and bar environments may shift to low-energy wetland and low-floodplain fluvial systems. This long-term transition may not be gradual in either time or space, but depending on climate, hydrology, and sediment supply, may occur as back-and-forth transformations. The North Fork Sprague River apparently has alternated already between such conditions since the Mazama eruption, perhaps indicating future sequences on other parts of the fluvial system.

\section{Human Influences}

Overlaying geologic controls of flood-plain and channel processes and conditions is the locally strong influence of human manipulation. Alterations range from subtle, such as historical vegetation changes as discussed in more detail in the section, "Flood-Plain and Riparian Vegetation," to substantial, such as channelization and confinement of the South Fork Sprague River. The types of human influences have changed over time, from flow diversion, beaver eradication, and log transport practices in the early 1900s, to levee construction and channelization in the mid-1900s, followed by more recent channel and flood-plain manipulation as part of restoration projects (NewFields River Basin Services and Kondolf, 2012). The various scales, intensities, and confounding effects of all these activities challenge direct attribution of specific human activities to specific consequences for the Sprague River study area, but general conclusions can be drawn from overall observed changes to flood-plain and channel conditions and known linkages among disturbance factors and channel and flood-plain processes.

\section{Channel and Flood-Plain Manipulation}

The most evident human manipulations with direct and continuing effects on channels and flood plains in the study area are channelization and flood-plain confinement. The South Fork valley segment in particular has been straightened and confined, directly causing the low sinuosity and high slope of this valley segment compared to other unconfined valley segments. Channelization was mostly prior to 1940 and perhaps mostly subsequent to 1925 , given the May 18, 1925 notes by USGS streamgager K.N. Phillips of a "very crooked" channel (USGS Oregon Water Science Center, Portland, Oregon, measurement station records for station 11495500). Confinement, channelization, and the consequent loss of sinuosity and increase in slope have almost certainly led to the transformation from a wet meadow fluvial system at the time of the GLO surveys to the locally straight and incised present channel. Incision likely began at the time of channelization but evidently has continued in the lower part of the South Fork valley segment through at least 1968 . This incision likely contributed to local channel widening in this segment since the GLO surveys (fig. 41). The locus of present incision probably is upstream of Campbell Road Bridge (FK 101.5), given the greater suspended sediment concentrations in that reach (fig. 55) as well as the irregular channel profile (fig. 32). Diversion structures at FK 100.0 and 101.5 apparently have slowed incision for parts of the South Fork valley segment (fig. 32). 
Although the South Fork Sprague River is the valley segment with most substantial channel realignment and confinement and most clear consequences, confinement has probably affected other unconfined valley segments in less obvious ways. In particular, the overall loss of sinuosity since 1940 for most unconfined valley segments and decrease in channel migration rates are both consistent with the effects of confinement by roads, railroad grades, and levees. These effects are most evident for the Kamkaun Spring, Buttes of the Gods, and Council Buttes valley segments. Additionally, the flood-plain stratigraphy along the main-stem, South Fork, and North Fork Sprague Rivers shows coarsening toward the top, including sequences of post-1950 deposition as indicated by the presence of $\mathrm{Cs}^{137}$ (figs. 8, 9). This coarsening possibly represents higher-velocity overbank flow, possibly augmented by flood confinement. Similarly, the locally high incidence of avulsions and chute cutoffs in the 1940-68 period (fig. 59) may represent confinement creating deeper, faster, and more erosive overbank flow than during earlier times of unconfined flood-plain conditions.

Although not quantifiable from this analysis, levees, roads, ditches, and railroad embankments likely have substantially affected lateral connectivity (Poff and Ward, 1990) within the Sprague River flood plain. Two factors contribute to this: (1) In the incised reaches (including the South Fork and possibly parts of the Upper Valley, Beatty Gap, and Council Butte segments), the frequency of floodplain inundation probably is reduced, although without detailed understanding of historical topographic conditions, documenting the magnitude of change is not possible. (2) The areal extent of seasonal flood inundation is reduced by levees and dikes, preventing sediment, water, and organic material transfers between flood plain and channel during floods. The thin but extensive overbank deposition during the 2006 high flows (fig. 52) as well as the young overbank deposits in the stratigraphic exposures of flood-plain deposits (fig. 8) confirms the importance of overbank flooding in flood-plain formation.
Dams and diversions have reduced longitudinal connectivity since the first diversion dams were constructed in the South Fork valley segment in the 1890s. The most significant such blockage was Chiloquin Dam at FK 1.3. Other small dams were constructed throughout the study area during the early and mid-1900s for log storage and transport, and water diversions. With the advent of pumping and the demise of the local timber industry, nearly all these structures have been removed. The only diversions presently affecting the channel profile are the 1-to-2-m-high structures diverting flow along the North Fork and South Fork Sprague Rivers (fig. 32). Although these structures affect low-flow conditions by diverting water from the channel into irrigation networks, the ecologic and geomorphic effects of these structures are uncertain except for their likely control on upstream migration of incision-related knickpoints.

Since the 1990s, efforts to restore channel and floodplain conditions have resulted in various channel alterations and realignments (NewFields River Basin Services and Kondolf, 2012). A primary objective has been to restore sinuosity by plugging meander cutoffs and avulsion channels and relocating the primary channel into historically occupied locations (fig. 23). Such efforts have focused on the Kamkaun Spring, Council Butte, and Beatty-Sycan valley segments, where meander cutoffs have been frequent over the last several decades (figs. 47, 59). When implemented and stable, these channel manipulations increase sinuosity and decrease local channel slope, but they typically include some form of bank hardening (commonly rock or anchored wood) that suppresses channel migration processes. Additionally, channel remeandering in itself typically does not address some of the local factors that may have contributed to increased rates of meander cutoffs, such as flood-plain confinement by levees and dikes.

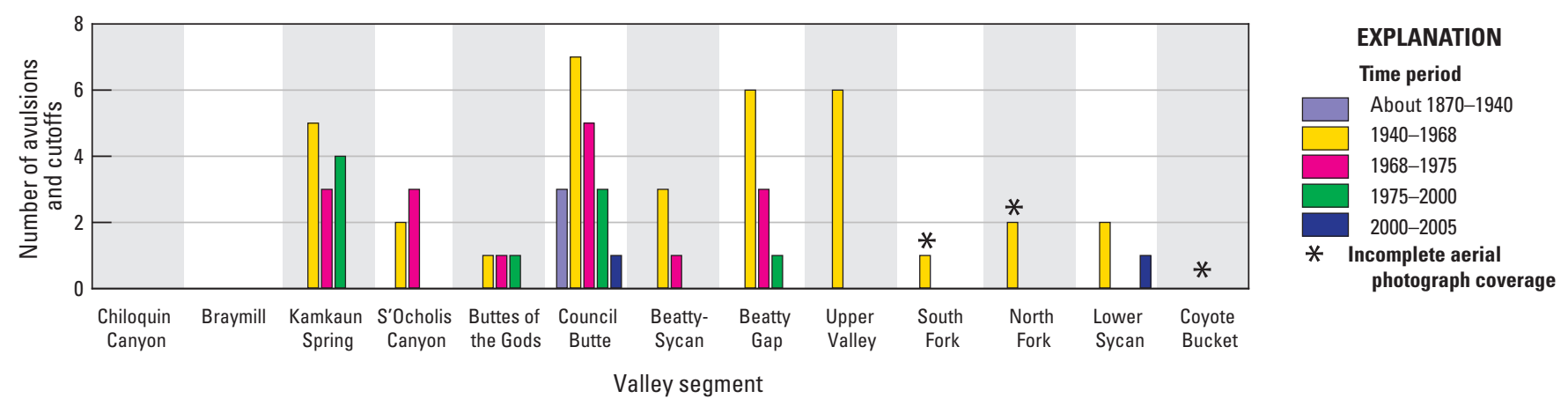

Figure 59. Avulsions and cutoffs, summarized by valley segment, Sprague River Basin, Oregon. General Land Office (about 1870)-to-1940 avulsions only were determined for parts of Council Butte and Beatty-Sycan valley segments where the channel was meandered. Observations from South Fork, North Fork, Lower Sycan, and Coyote Bucket valley segments were limited for some periods by incomplete map and photographic coverage. 


\section{Grazing Management}

Livestock or wild ungulate grazing in riparian areas can lead to decreased streamside vegetation and bank trampling, both of which increase susceptibility to fluvial erosion. Overgrazing has been associated with channel widening, incision or aggradation depending on the particular stream characteristics, and loss or diminution of other processes related to aquatic habitat (Armour and others, 1991; Trimble and Mendel 1995; National Research Council, 2002). Grazing effects are evident at some locations along the Sprague and Sycan Rivers in the form of trampled banks and heavily browsed shrubs or grasses, although affected areas presently are limited in extent. Fencing and other methods to reduce livestock effects on the riparian zone have been adopted for some properties along the Sprague River. Effects of grazing on the channel banks and riparian zone likely were more extensive in the past, although no direct evidence is available for documenting changes in grazing intensity. Vegetation changes documented in the section, "Flood-Plain and Riparian Vegetation," particularly a decrease in short woody shrubs between 1940 and 1968, are consistent with more intense grazing in the past.

\section{Other Historical Activities}

Besides the ongoing influences of channelization, diversions, levees, flood-plain confinement, and grazing practices, other historical activities also may contribute to present channel and flood-plain conditions in the study area. In particular, past timber practices and beaver eradication may have continuing effects on channel conditions, although the passage of several decades since these activities obscures evidence of their effects.

Timber harvest has likely decreased the volume of river-transported logs and large woody debris accumulations, especially in the confined valley segments where ponderosa pine colonizes the flood-plain and flanking surfaces. Although past and present wood flux is uncertain in the Sprague River system, it was (and is) likely small compared to forested flood plains. Nevertheless, in-channel wood provides a variety of channel structures and habitats (Gregory and others, 2003; Montgomery and others, 2003), and in supplylimited systems such as the Sprague River can promote deposition of bed material (Massong and Montgomery, 2000). Decreased transport of large wood also possibly has affected flood-plain environments. Wood deposition on flood-plain surfaces can provide ecological functions - well documented for forested alluvial valleys ( $\mathrm{O}^{\prime}$ Connor and others, 2003c; Collins and others, 2012), but less understood in sparsely timbered environments such as the wide valley segments of the study area. Contrasting with a likely overall long-term decrease in large wood transport in the Sprague River fluvial system is the period of substantial fluvial wood transport during the first few decades of the 1900s, when the Sprague River was used for the storage and transport of saw logs (fig. 20). These operations resulted in substantial flow fluctuations (USGS Oregon Water Science Center, Portland, Oregon, measurement station records for station 11501000). Log transport during this time likely scoured banks of sediment and vegetation, possibly widening channels, but no quantitative measurements are available to document specific and persistent effects. Log drives and in-river storage probably diminished substantially after the 1928 completion of the OC\&E railroad to Bly.

An even earlier activity, beaver eradication, also may have affected channel and flood-plain conditions in the study area. Several beaver lodges currently flank the channel in the study area, locally impounding flow in side channels and irrigation canals. However, beaver evidently were more common in the early 1900s in the Sprague River Basin, given A.W. Moore's 1943 survey of 32 abandoned colony sites in the Chiloquin Canyon, Braymill, and Kamkaun Spring valley segments (unpub. wildlife resource report by A.W. Moore, 1943, U.S. Fish and Wildlife Service, in Klamath Indian Agency records, National Archives, written commun. from Larry Dunsmoor, The Klamath Tribe, 2006). Moore further concluded that "while the beaver population has been severely depleted, it is believed that where trapping of the animal stopped, a satisfactory population would build up in from seven to ten years." Bailey (1936, p. 223) noted that "in 1914, L.J. Goldman reported them [beaver] on the west slope of the Yamsay Mountains, on the Sprague and Yamsay Rivers [upper Williamson], and in Klamath Marsh," and that "in July 1927, there were still a few beavers in Sprague River and its branches north and east of Bly..." "[C]hannel in general very crooked, winding through beaver dam land..." noted USGS hydrologist K.N. Phillips in 1926 at the North Fork Sprague River measurement site, then located at Bailey Flat, a 2-km-long alluvial reach $3 \mathrm{~km}$ upstream of the upstream extent of the North Fork valley segment (USGS Oregon Water Science Center, Portland, Oregon, streamflow-gaging station records for station 11496500). As was the case throughout western North America (Jenkins and Busher, 1979), beaver populations were mostly eradicated by fur traders throughout Oregon by the mid-1850s (Bailey, 1936), although the timing of their demise in the Sprague River area is unknown.

The exact role of beaver on channel and flood-plain morphology in the Sprague River Basin also is uncertain. In many low-gradient montane basins of western North America, beaver can substantially affect channel morphology, in places creating extensive areas of wet meadows and promoting valley-bottom aggradation (Ives, 1942; Naiman and others, 1988; Kramer and others, 2012). In the Sprague River Basin, beaver dams likely played a role in the formation and maintenance of the historical wet meadow complexes historically occupying the South Fork valley segment as well as earlier episodes of wet meadows evident in the bank stratigraphy flanking the North Fork Sprague and Sycan Rivers (figs. 5, 9). Beaver-chewed stick fragments commonly were found within these exposures. Given these observations, 
local reductions in beaver population likely contributed to loss of wet-meadow environments in the South Fork Sprague and North Fork Sprague valley segments and possibly contributed to channel incision in the Upper Valley and Beatty Gap valley segments.

Timber harvest and land use can affect flood-plain morphology indirectly by altering hydrologic regimes, which in turn affect channel and flood-plain processes. Timber harvest has increased peak streamflows at some locations in the Oregon Cascade Range (Jones and Grant, 1996, Beschta and others, 2000; Grant and others, 2008), and such changes to peak flows could have affected Sprague River stream channels, particularly between the 1920s and 1960s when harvest was most intense in the basin. However, the magnitudes of these changes are not known and their effects likely are to have been small compared to direct flood-plain and channel modifications. Low flows and total runoff were more likely affected than peak flows for the Sprague River study area, particularly by implementation of irrigation systems (U.S. Department of Agriculture, 2009). Some of the historical precipitation-runoff changes noted by Risley and Laenan (1999) may be a consequence of timber harvest and changing irrigation practices; such changes may affect riparian vegetation, but they probably have had little effect on physical channel and flood-plain processes.

\section{Summary of Physical Flood-Plain and Channel Conditions, Processes, and Trends}

Strong geologic controls have resulted in distinct valley segments within the alluvial portion of the Sprague River Basin, ranging from low-gradient reaches with expansive flood plains to steep and narrow canyon segments. The wide flood-plain valley segments are broadly similar; most contain a sinuous, low-gradient channel that migrates slowly across the valley bottom. The narrow valley segments include the steep, boulder-and-cobble-bed Chiloquin Canyon, at the downstream end of the study area, and the Coyote Bucket valley segment as the Sycan River leaves Sycan Canyon. The other confined valley segments - Braymill, S'Ocholis Canyon, and Beatty Gap - have similar gradients and substrates as adjacent unconfined valley segments, but much lower sinuosities. Although the geologic setting of the expansive South Fork valley segment resulted in historical conditions of sinuous and poorly defined channels and wet meadows, flanking levees now narrowly confine the channelized South Fork Sprague River for much of its length.

The fine-grained extrusive volcanic rocks and lacustrine sediment that constitute most of the Sprague River Basin produce little sand and gravel bed material. In the absence of substantial bed material prior to the Mazama eruption of $7,700 \mathrm{cal} y \mathrm{BP}$, the main rivers of the study area apparently were flanked by wetlands and low flood plains, and migration rates probably were very low. The eruption, however, covered much of the northern basin with sand- and granule-size pumice clasts, transforming the fluvial system by increasing bed-material transport and promoting bar formation and channel migration, particularly for the Sycan River, North Fork Sprague River, and Sprague River downstream of its confluence with the Sycan River. The South Fork Sprague River, which had much less Mazama pumice deposited in its watershed, remained a low flood plain and wet meadow fluvial system until historical channelization and diking.

Despite the pumiceous sand input and the general low gradients of the main channels within the study area, the present overall bed-material sediment regime is supply limited, meaning the transport capacity exceeds the supply of bed material. This is evident by the discontinuous alluvial cover of the channel bottom, the sparse bars in and flanking the channel, and the overall slow channel migration rates for the Sprague River compared with many western North American rivers.

Despite slow channel migration rates, lateral channel movement is an important process for maintaining channel and flood-plain materials, form, and function. Movement is by continuous lateral migration associated with bar formation, lateral accretion, and bank erosion, as well as by translocations by avulsion and meander cutoffs. Lateral migration forms and expands meanders, increasing sinuosity. In unconfined valley segments, sinuosity values typically exceed 1.6 (fig. 60). The positive correlation between migration rates and bar area attests to the strong coupling between bed-material deposition and lateral channel movement.

Avulsions and meander cutoffs counter meander enlargement, including chute and neck cutoffs, which reduce sinuosity. Avulsions and chute cutoffs are much more common in the study area than neck cutoffs. Avulsions and chute cutoffs require overbank flow, whereas neck cutoffs do not. In some instances, ice jams may promote overbank flow and resulting cutoffs. The decrease in sinuosity since 1940 for nearly all the unconfined valley segments (table 2) owes partly to decreased migration rates, but mostly to cutoffs and avulsions, mainly between 1940 and 1975 (fig. 60). The frequency of avulsions and meander cutoffs may have been enhanced historically by (1) flood-plain confinement by levees, dikes, roads, and railroads leading to deeper and faster overbank flow, thereby promoting erosion of new flood-plain channels; and (2) flood-plain disturbances such as trails, ditches, and vegetation manipulation or eradication, thereby locally concentrating overbank flow and more generally decreasing surface resistance to channel erosion.

For the most part, the Sprague River is not incised to the extent that floods fail to inundate the flood plain. The 2006 flood left overbank deposits on flood-plain surfaces along the entirety of the main-stem Sprague, lower Sycan, and lower North Fork Sprague Rivers, consistent with the stratigraphic evidence of substantial flood-plain deposition and construction during the last several hundred years. The stratigraphy of exposed bank sections and along augering transects also 


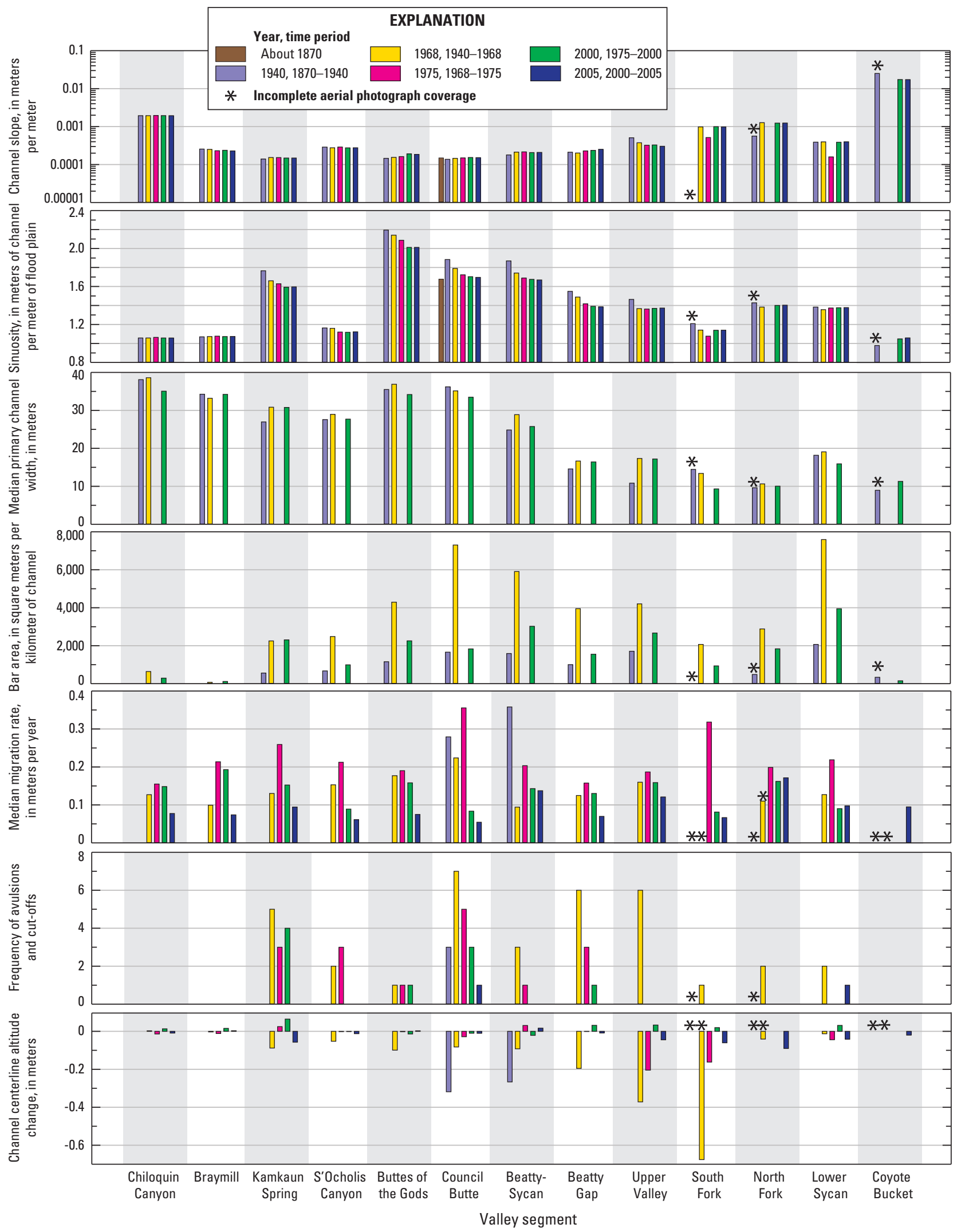

Figure 60. Summary trends of major flood-plain and channel attributes, summarized by valley segment, Sprague River Basin, Oregon. 
indicates little or no incision during the last 4,000 years within most of the study area, including the North Fork and Lower Sycan valley segments. As much as $1.6 \mathrm{~m}$ of historical incision is evident in the upstream part of the study area, chiefly in the South Fork valley segment, but also possibly including parts of the Upper Valley and Beatty Gap valley segments. For the South Fork valley segment, incision (along with ditching and levee construction) has transformed areas of wet meadow at the time of the 1866 GLO surveys to rarely inundated flood plain. The locus of ongoing incision in the South Fork valley segment appears to be primarily upstream of FK 101.4.

The general absence of channel incision for much of the study area is consistent with little evidence of channel widening (fig. 60). Neither analyses using the GLO surveys (fig. 41) nor those of historical aerial photographs (ig. 43) substantiate overall widening or narrowing trends in channel width. Since the GLO surveys, wide channels have narrowed and narrow channels have widened. For measurements going back to the earliest aerial photographs of 1940, the channel generally was widest in the 1968 aerial photographs, probably representing channel widening during the high flow of December 1964. Between 1968 and 2000, most segments narrowed to widths very similar to those measured from the 1940 photographs. The Council Butte valley segment is unique in having a systematic narrowing trend for the entire time period. The variance in channel width has decreased since 1940 for several valley segments, particularly upstream of S'Ocholis Canyon (fig. 43).

All measurements, stratigraphic analyses, and other observations point to the important role of flooding in creating and maintaining channel and flood-plain conditions. Floods promote channel movement, including lateral migration and meander cutoffs, which together create a dynamic mosaic of channel and flood-plain landforms. Floods deposit water, sediment, and organic materials in the channel and overbank areas. Large floods, as in 1964, and moderate floods, as in 2006, can have persistent effects including bank erosion, channel widening, bar building, and overbank flood-plain deposition, as well as creation of new channels from avulsions and cutoffs.

The Sycan River is unique because of the great influence of the 7,700 cal yr BP Mazama eruption on its catchment. The Sycan flood, shortly after the eruption, formed a surface underlain by loose and coarse pumiceous sand that now flanks the channel and younger flood plains. Where disturbed, this surface contributes substantial sand to the Sycan River. Subsequent to the flood, episodes of watershedscale, enhanced sediment supply resulted in construction of sandy flood plains flanking the channel, which continue to be susceptible to lateral erosion. This situation results in a Lower Sycan valley segment with abundant bars, wide channels, and high migration rates relative to other valley segments. Additionally, these local sediment sources make the Sycan River a major source of bed material for the Sprague River, as indicated by the high bar frequency and bar-area measurements in the Council Butte valley segment near the Sycan River confluence (fig. 60).

The Mazama eruption had much less effect on the South Fork Sprague River; consequently, the historical condition of its fluvial systems probably was much different from that of the Sycan River and, to a lesser extent, the North Fork Sprague River. At the time of the GLO surveys and for thousands of years earlier, the South Fork Sprague River probably was a poorly defined, stable (and locally multi-thread) channel and wet-meadow complex fringed by willows. The expansive valley bottom likely was seasonally flooded and slowly aggrading, with peats and organic-rich marsh and low-energy fluvial deposits. Beavers likely had a strong role in controlling local flood-plain and channel conditions.

The South Fork valley segment has been the most transformed of all the valley segments since first historical observations. The present channel is incised, straightened, and separated from the flood plain by levees for much of the valley segment. Significant portions of the flood plain have been drained and leveled. In-channel structures currently divert flow into irrigation ditch networks. The South Fork valley segment also appears to be a major source of suspended sediment to the Sprague River fluvial system.

Since first European settlement in the 1860s, human actions locally have affected Sprague River channel and flood-plain conditions. Early activities such as beaver trapping and timber harvest (and associated activities) almost certainly had consequences for channels and flood plains, although their persistent effects are unknown. Similarly, the consequences of late-19th- and early-20th-century diversions, dams, timber harvest, and saw-log transport are unclear. More evident are the contemporaneous and persistent effects of channelization and flood-plain confinement by levees, roads, and the former OC\&E railroad alignment, mainly dating from the 1920s through the 1970s. Channelization before 1940 in particular has directly transformed the South Fork Sprague River between FKs 97.0 and 101.0. Less evident are the effects of levees, but flood-plain confinement probably has increased the frequency of avulsions and cutoffs, resulting in reduced sinuosity and overall greater channel slopes since 1940. Riparian grazing and channel and bank trampling by cattle locally have affected bank and channel conditions, as have local accumulations of dumped rock at fords and former bridge crossings. Channel restoration and remeandering, chiefly since 2000 , locally has resulted in the filling of chute cutoffs, avulsions, and the placement of the primary channel back in its historical positions. These restoration efforts, however, commonly are engineered with anchored materials to decrease future channel migration. 
Despite these broadscale and local effects of human disturbances, many of the fundamental processes that have shaped the Sprague River fluvial systems over the last several thousand years are still present to varying degrees. Most importantly, the overall bed-material transport regime (including sediment supply and water flow, which drives processes of bar building and channel migration), has not been affected substantially by upstream impoundments interrupting either flow or sediment. The absence of system-wide channel incision also is important; incision fundamentally alters channel and flood-plain processes (particularly lateral exchanges of water, sediment, and organic materials), and can limit restoration opportunities (Simon, 1989; Simon and Rinaldi, 2006; Cluer and Thorne, 2013). Incised areas of the fluvial system, particularly the South Fork valley segment, are in the upstream part of the study area, limiting the likelihood that geomorphic effects (aside from changes in flow and sediment transport) will migrate to other parts of the study area, since channel incision typically migrates upstream. These factors suggest that restoration of many of the historical physical conditions and processes is possible for much of the Sprague River study area without substantial physical manipulation of current conditions.

\section{Flood-Plain and Riparian Vegetation}

Vegetation interacts strongly with channels and flood plains. Patterns of vegetation within basins are controlled by geomorphic character and prevailing land uses, commonly varying locally and with time. Vegetation, in turn, can affect processes and rates of fluvial erosion and deposition. Flood-plain vegetation in western, semi-arid basins such as the Sprague River Basin chiefly owes to substrate conditions, moisture availability, and disturbances such as flooding (Bornette and Amoros, 1996; Hupp and Osterkamp, 1996; Bendix, 1997; Castelli and others, 2000; Amlin and Rood, 2002; Chapin and others, 2002; Li and others, 2006; Bornette and others, 2008).

Processes controlling flood-plain vegetation differ spatially relative to the channel. Fluvial processes of inundation, scour, and burial disturb near-channel environments more frequently than distal ones (Hupp and Osterkamp, 1996; Cordes and others, 1997), but also provide more opportunities for establishment of typical riparian species (Karrenberg and others, 2002; Gurnell and others, 2008). These natural processes involving vegetation can be altered substantially by land use. In the Sprague River Basin, such alterations include drainage, diking, and cultivation of expansive flood-plain areas; livestock grazing; local timber harvest in some valley segments; and extensive willow and riparian shrub removal as part of mid-20th-century channelization and flood mitigation efforts.
The analysis of flood-plain vegetation parallels the analysis for physical channel and flood-plain conditions by relying on historical observations and systematic mapping from the 1940, 1968, and 2000 aerial photographs. These analyses are combined with available general understanding of riparian vegetation processes to infer mechanisms for evident trends and transitions in vegetation conditions since the first historical observations. Specifically evaluated are (1) the relations among general vegetation patterns and flood-plain geomorphology, (2) temporal variations in these patterns, and (3) the relation of these temporal and spatial patterns of vegetation conditions to geomorphic processes and land-use history. The analysis is broadscale, with limited evaluation of individual species. More information on the factors controlling distribution of vegetation types in the Sprague River Basin is provided by Rasmussen (2011).

\section{Overview of Current Flood-Plain Vegetation}

Vegetation conditions generally are controlled by the characteristics of the valley segments (table 2), indicating the important influence of channel gradient, sediment supply, floodplain width, and major tributaries. Narrow valleys generally have higher-energy streamflow and coarser channel and floodplain sediments than wide valley flood plains. Narrow valleys also have higher banks and more topographic shading than wide valley flood plains. Wide valleys have space for development of channel meanders and more flood-plain wetlands than narrow valleys. Spring complexes in the flood plain and adjacent surfaces are flanked by riparian and wetland vegetation. Additionally, distinct differences in typical land use among the valley segments lead to important differences in resulting vegetation conditions.

The very narrow Chiloquin Canyon, Braymill, and Coyote Bucket valley segments are vegetated largely with woody species, including willow and ponderosa pine. Small patches of quaking aspen are present locally, and, in the Chiloquin and Braymill segments, there are a few individual cottonwood. The slightly wider S'Ocholis Canyon and Beatty Gap valley segments have a mix of shrubs, herbaceous species, and some trees, with small patches of aspen in both segments. Vegetation in wide flood-plain segments mostly is herbaceous, but willows locally flank present and former channel edges. Generally, tall banks in confined valley segments commonly support dense shrub communities, whereas low stream banks with saturated soils, common in unconfined valley segments typically do not (Rasmussen, 2011). Although the geomorphic flood plain of the Lower Sycan valley segment is relatively narrow, it is flanked by the broad, dry, and rarely inundated Sycan flood deposits that are vegetated by upland grasses and shrubs. The invasive species, reed canarygrass, is present throughout the study area in near-channel areas of both wide and narrow valley segments, but is particularly common in the Chiloquin Canyon and Braymill valley segments. 


\section{Historical Flood-Plain Vegetation Conditions}

Understanding historical vegetation conditions provides a basis for evaluating the relation of flood-plain vegetation to channel and flood-plain processes, as well as a means for evaluating changes since 1940 resulting from land-use conditions and changing process regimes. The main sources documenting early vegetation conditions in the study area are the maps and records of the GLO surveys and records of botanists travelling through the region.

\section{Vegetation Conditions Inferred from GLO Surveys and Notes}

As with channel conditions, the GLO surveys can provide some quantitative information on vegetation conditions. These surveys, conducted between 1866 and 1892 (table 3), include (1) plat maps showing generalized cover, with notations such as "forest," "bottomland," and "marshes;" (2) section line notes describing landscape conditions along surveyed section lines; and (3) "witness tree" descriptions documenting trees near surveyed section corners.

Observations recorded on the plat maps (table 9) indicate that the wide valley segments had sparse tree cover. By contrast, the narrow Chiloquin Canyon and Braymill valley segments were described as forested, and the $\mathrm{S}^{\prime}$ Ocholis Canyon and Beatty Gap valley segments were a mix of herbaceous and timber cover types.

The GLO section-line notes documented general conditions along surveyed lines. Surveyors often noted transitions between forest and prairie with statements such as "leaving river bottom" or "entering timber." Survey descriptions emphasized timber and grasslands (or prairies), in accordance with resources attractive to homesteaders. No section-line surveys specifically describe riparian vegetation, except for the Beatty Gap and Upper Valley segments, where large willows served as witness trees (table 9). Surveyors did not note aspen stands in Beatty Gap, S'Ocholis Canyon, or other narrow valley segments, although some aspen patches exist currently and were present in the 1940s.

Section corners and the midpoints of section lines were marked with charred posts, pits, or rock piles. Marker locations were related to as many as three nearby "witness trees." The surveyor recorded the species and diameter of each witness tree, and its direction and distance from the marker. An absence of witness trees indicates a lack of nearby trees, thereby indicating non-forest cover (table 9). Smaller shrubs or willows likely were present, but are not mentioned. Pine trees were recorded on flood-plain surfaces only in Kamkaun Spring, S'Ocholis Canyon, and the Lower Sycan valley segments. Notes mention a single aspen witness tree in the Braymill valley segment. These conditions are consistent with the very general land classification of Leiberg (1903) encompassing most of the study area west of FK 91.8.
The broad vegetation characteristics noted during the GLO surveys currently persist: few trees in the unconfined valley segments, but more forested conditions, including pine and willow, in the narrower valley segments. The wide valley segments were most commonly described as "prairie" although swampy soils and wetland vegetation were noted for the South Fork valley segment.

\section{Historical Notes from Botanist William E. Lawrence}

Historical observations from the late 1800s (Gatschet, 1890; Leiberg, 1903) are consistent with the inferences of general vegetation conditions noted in the GLO surveys. Slightly later but more specific information is provided by Oregon State University (then College) botanist William E. Lawrence, who travelled from Klamath Falls to Lakeview, Oregon, in 1922 and 1934, both times describing vegetation in his field notebooks (W.E. Lawrence, Oregon State University Herbarium, Corvallis, Oregon, unpublished field journals). In each instance, his route provided views of the Beatty-Sycan, Beatty Gap, and South Fork Sprague valley segments as he closely followed the present route of Oregon State Highway 140 eastward. Observations by W.E. Lawrence include the following:

July 1, 1922

No trees are to be found in the Beattie flat. The kind of sage was not noted.

Ribes aureum [golden currant] grew very luxuriantly along the creek in Beattie valley. Salix [willow] was very abundant along the stream...

Salix, Ribes aureum, Amelanchier [serviceberry], Prunus demissa [chokecherry], Populus [most likely aspen, unlikely cottonwood], Urtica [nettle], Rosa sp. [wild rose] were seen abundantly along the Sprague River.

In brief it was Populus, etc. and Ribes aureum along the river. Kunzia tridentate [bitterbrush; Purshia tridentata] then Artemesia tridentat [a] [sagebrush] and a little Ribes cereum [wax currant] with yellow pine [ponderosa pine] farther up.

Hay farming characterizes the productive areas here.

July 3, 1922

The currants grow in quantity along the creek bottoms. This is Ribes aureum. It is along the Sprague River in quantity. It extends from above Bly at Sec. 10T 37R 16 [upstream of the study area] down the river in abundance for 8 miles. It grows here in thick bodies. Below here it extends scattering with the willows down into the Reservation [west of the North Fork and South Fork Sprague Rivers confluence]. 
Table 9. Vegetation notes from General Land Office surveys, by valley segment, Sprague River Basin, Oregon.

[No records obtained for Chiloquin Canyon, Braymill, and Coyote Bucket valley segments. Abbreviations: GLO, General Land Office; T, Township; S, South; R, Range; E, East; cm, centimeter; -, no data available]

\begin{tabular}{|c|c|c|c|c|}
\hline $\begin{array}{c}\text { Valley } \\
\text { segment }\end{array}$ & $\begin{array}{l}\text { Observations recorded } \\
\text { on plat maps }\end{array}$ & $\begin{array}{l}\text { Flood plain notes from } \\
\text { section line survey }\end{array}$ & $\begin{array}{l}\text { Flood plain witness trees, as } \\
\text { recorded in GLO notes }\end{array}$ & Comments \\
\hline Kamkaun Spring & $\begin{array}{l}\text { Lower Kamkaun drawn as } \\
\text { non-forested in valley bottom, } \\
\text { timber on uplands. T34S R8E }\end{array}$ & $\begin{array}{l}13 \text { section boundary lines } \\
\text { surveyed; two noted as } \\
\text { "Prairie"; others no } \\
\text { description. }\end{array}$ & $\begin{array}{l}12 \text { monumented corners, } \\
2 \text { with pine witness trees, } \\
10 \text { with no witness trees. }\end{array}$ & $\begin{array}{l}\text { Mix of timber and prairie on } \\
\text { both uplands and flood plain. } \\
\text { Open river bottom interpreted } \\
\text { as prairie. }\end{array}$ \\
\hline $\begin{array}{l}\text { Buttes of the } \\
\text { Gods }\end{array}$ & - & $\begin{array}{l}6 \text { section boundary lines } \\
\text { surveyed; } 1 \text { noted as } \\
\text { "Prairie"; } 5 \text { as "No } \\
\text { timber." }\end{array}$ & $\begin{array}{l}15 \text { monumented corners, } \\
\text { none with witness trees. }\end{array}$ & - \\
\hline Beatty-Sycan & - & $\begin{array}{l}4 \text { section boundary lines } \\
\text { surveyed, } 2 \text { noted as } \\
\text { "No timber." }\end{array}$ & $\begin{array}{l}5 \text { monumented corners, } \\
\text { none with witness trees. }\end{array}$ & - \\
\hline Beatty Gap & - & $\begin{array}{l}8 \text { section boundary lines } \\
\text { surveyed, } 4 \text { noted as } \\
\text { "No timber." }\end{array}$ & $\begin{array}{l}5 \text { monumented corners, } \\
1 \text { with willow witness tree, } \\
4 \text { with no witness trees. }\end{array}$ & $\begin{array}{l}2 \text { willows used as witness } \\
\text { trees, } 7.5 \text { and } 20 \mathrm{~cm} \\
\text { diameters. }\end{array}$ \\
\hline North Fork & - & $\begin{array}{l}9 \text { section boundary lines } \\
\text { surveyed, } 3 \text { noted as } \\
\text { "No timber." }\end{array}$ & $\begin{array}{l}5 \text { monumented corners, } \\
\text { none with witness trees. }\end{array}$ & - \\
\hline Lower Sycan & - & $\begin{array}{l}8 \text { section boundary lines } \\
\text { surveyed, } 3 \text { noted as } \\
\text { "Prairie." }\end{array}$ & $\begin{array}{l}4 \text { monumented corners, } \\
2 \text { with pine witness trees, } \\
2 \text { with no witness trees. }\end{array}$ & - \\
\hline
\end{tabular}


July 30, 1934

Sprague River junction [near Beatty]. There is an extensive natural meadow flat here which extends along the river bordered with Salix.

From here [probably in the Upper Valley segment] the Sprague River is seen to the left (north) with natural meadow pasture on bottom and bordered by willows. This widens out to the Bly area.

Bly...has certainly grown since 1922 when last I passed through. The saw mill has evidently brought about the change.

From these observations, it appears that at the time of Lawrence's travels, much of the Sprague River corridor upstream of Beatty had a distinct riparian vegetation community, including locally thick growths of shrubby species, including willow, interspersed with grass meadows. Higher surfaces were vegetated with typical semi-arid shrubby species such as sagebrush and bitterbrush. However, consistent with the diking and diversions already in place, "productive areas" were cultivated for hay.

\section{Aerial Photograph Analysis}

An analysis of the vertical aerial photographs dating from 1940, 1968, and 2000 (table 4) provides a quantitative assessment of vegetation conditions for the period 1940-2000. This analysis was based on vegetation mapping in conjunction with the mapping of channel and cultural features (table 5). The mapping and analyses were conducted at two spatial scales: (1) at the broad scale of the entire flood plain; and (2) closer to the channel within a 40-m-wide swath centered about the primary channel centerline, referred to as "the near-channel area."

\section{Vegetation Mapping and Analysis}

The mapped vegetation classes are (1) water (2) bare, (3) herbaceous, (4) short woody, and (5) tall woody (table 10). The woody classes approximately match National Wetland Inventory protocols that divide Forested and Scrub-Shrub wetland types at the 6-m threshold (Cowardin and others, 1979). As in the National Wetland Inventory method, trees less than 6-m-high are classified as "short woody." Mapping was done for the entire geomorphic flood plain for each of the three sets of aerial photography, with all areas of the flood plain classified into one of the five vegetation classes for each set.

As for the channel and flood-plain geomorphic characteristics, the different sets of aerial photography introduced some challenges for consistent vegetation mapping. The 1940s set was made at different times over the summers
Table 10. Mapped cover types.

[From Cowardin and others, 1979]

\begin{tabular}{ll}
\hline \multicolumn{1}{c}{ Cover type } & \multicolumn{1}{c}{ Characteristic } \\
\hline Water & Surface water \\
Bare & Exposed soil, roads, and buildings with no vegetation \\
Herbaceous & Grasses, sedges, rushes, non-woody vegetation \\
Short woody & Woody stands less than 6 meters tall \\
Tall woody & Woody stands greater than 6 meters tall \\
\hline
\end{tabular}

of 2 years and covered a smaller area than in 1968 and 2000 (table 4). All photographic sets used were black and white, although a high-resolution, true-color set from 2005 enabled the checking of type and position of vegetation stands. Vegetation types also were field verified in several places. The North Fork and South Fork valley segments had little coverage in the 1940s photographic set; consequently, results from these valley segments only are used for some analyses. Because of limited aerial photograph coverage, the Coyote Bucket segment of the Sycan River was not included in any vegetation analyses.

Mapping involved delineating patches of vegetation classes (except for herbaceous), typically at scales ranging from 1:1,000 to 1:2,000. The minimum patch size was $20 \mathrm{~m}^{2}$, or for the short woody and tall woody classes, areas that included five or more individual trees separated by less than $20 \mathrm{~m}$. Individual trees were not mapped.

Tall and short woody vegetation was mapped primarily on the basis of structure rather than tree species; however, many tall woody species were recognizable from the imagery. In particular, pines were very dark on the photos, sometimes nearly indistinguishable from the accompanying shadows. Quaking aspen had round crowns for individual trees; larger stands had a mottled texture, and tone typically was darker than that of the shorter and patchier willow and lighter than that of the adjacent pine. Parts of the 1968 photographic set were taken prior to leaf-out for the aspen trees, making crown identification locally difficult, although crown shadows were distinctive, even without leaves, making mapping possible in most cases. Short woody vegetation primarily was composed of young trees of the tall woody species, as well as willow and other shrubs typically found along channels.

After all woody vegetation was mapped, areas without any vegetation were delineated and classified as bare. Houses, roads, and bridges were classified as bare. Consistent with field conditions, all surfaces not mapped as water (from the physical flood-plain mapping), tall woody, short woody, or bare were assumed to be covered with herbaceous vegetation. This mapping process resulted in all areas within the geomorphic flood-plain boundary being assigned one (and only one) of five cover-type classifications: water, bare, herbaceous, short woody, or tall woody. 


\section{Spatial Distribution of Vegetation in Year 2000}

The vegetation patterns mapped from the year 2000 aerial photographs (table 11; fig. 61) allow for the examination of the relation between recent vegetation patterns and flood-plain width, and the differences in vegetation patterns between flood-plain and near-channel zones. Other potential controlling factors such as stream or valley gradient, soil type, or flood-plain altitude, were not evaluated.

As expected, water (including all channels and backwater areas) covers a much greater percentage of the narrow flood plains than the wide flood plains, accounting for as much as 40 percent for the confined valley segments, such as Chiloquin Canyon, but less than 20 percent for most of the unconfined valley segments, such as Kamkaun Spring (tables 2, 11).

The confined valley segments have a much higher proportion of woody vegetation than the unconfined valley segments (table 11). Chiloquin Canyon, Braymill, S'Ocholis Canyon, and Beatty Gap all have more than 25 percent of their flood-plain areas covered by woody vegetation, compared to less than 10 percent for the unconfined valley segments. The unconfined Council Butte valley segment has woody vegetation covering less than 0.1 percent of the flood-plain area. The Lower Sycan valley segment, although narrow with a mean flood-plain width of $220 \mathrm{~m}$, has only 7 percent woody cover compared to the 32 percent woody cover for the slightly narrower Beatty Gap. Some of this difference results from the greater solar exposure (and probably drier conditions) of the Lower Sycan valley segment, which is oriented north-south and flanked by low terraces composed of coarse sandy soils, whereas the other narrow segments are within deeper and more shaded canyons. Part of the difference also probably owes to the substantial decline of woody cover in the Lower Sycan valley segment, which had 23 percent woody cover in the 1940 aerial photographs.

For all valley segments, most of the woody cover is short woody vegetation. Tall woody vegetation constitutes more than 15 percent of the cover only in the narrowly confined Chiloquin Canyon and Braymill valley segments. In all other segments, short woody vegetation cover exceeds tall woody vegetation by a factor of two or more (fig. 61, table 11). The Buttes of the God, Beatty-Sycan, and Upper Valley segments had no mappable tall woody vegetation in 2000 . The expansive Council Butte valley segment had less than 0.5 ha of tall woody vegetation, mostly planted trees adjacent to homesteads.

Herbaceous cover dominates the flood plains of the wide and unconfined valley segments, which all have more than 75 percent herbaceous cover (over 90 percent in the Upper Valley and South Fork valley segments). Herbaceous vegetation covers more than 50 percent of the flood plain for all valley segments in the study area except for the confined Chiloquin Canyon and Braymill valley segments.

Near-channel areas within $20 \mathrm{~m}$ of the channel centerline had vegetation patterns in 2000 similar to the corresponding flood-plain patterns, but with some consistent differences (table 12; fig. 62): (1) bare ground is a larger component of surface cover in the near-channel zone than for the flood plain, mostly active bar surfaces and bare banks along the channel; (2) tall woody vegetation is less prevalent in the near-channel zone than on general flood-plain surfaces, likely owing to the intolerance of aspen and ponderosa pine to the greater frequency and extent of soil saturation near the channel, and (3) short woody vegetation occupies a slightly greater percentage of the near-channel zone than of the whole flood plain in most valley segments.

The slightly greater abundance of short woody shrubs (typically willow) in the near-channel area may represent higher availability of seeds and germination sites, as is the case for riparian areas in many semi-arid regions (Karrenberg and others, 2002). The greater percentage of short woody vegetation in the near-channel areas (compared to the overall flood plain) is most pronounced in the narrow confined valley segments (Chiloquin Canyon, Braymill, S'Ocholis Canyon, and Beatty Gap). This may be the result of the slightly higher flood plains (fig. 17) or lower migration rates (fig. 44) in these valley segments.

\section{Vegetation Trends, 1940-2000}

Trends in vegetation patterns are evident from the vegetation mapping based on the 1940, 1968, and 2000 aerial photographs (tables 11, 12; figs. 61, 62). For the geomorphic flood plain, study-area totals from 1940 to 2000 (excluding the North Fork, South Fork, and Coyote Bucket valley segments for which aerial photograph coverage is incomplete) show a gain of herbaceous cover (increasing from 78.2 to 81.5 percent of the analysis area) and loss of short woody cover (decreasing from 7.7 to 4.8 percent of the study area) (table 11). Other changes were less than 1 percent, including slight gains in tall woody vegetation and bare areas and a loss of watercovered area. Although the area is small with respect to the total flood-plain area, the decrease in short woody vegetation between 1940 and 2000 represents a loss of 38 percent of its 1940 area and is by far the largest relative change in any of the mapped cover types.

Most of the change in total flood-plain cover of short woody vegetation was during the 1940-1968 period, when 138 ha were lost along the main-stem Sprague River and Lower Sycan valley segment (table 11). Subsequently, between 1968 and 2000, short woody vegetation cover decreased by an additional 6.6 ha. By contrast, herbaceous cover gained more area between 1968 and 2000, when its extent increased by 129 ha compared to an increase of only 36.6 ha during 1940-1968. Tall woody vegetation cover increased by small areas during each analysis period. The areas covered by water and bare ground each increased between 1940 and 1968, and then decreased between 1968 and 2000. The total net loss of water-covered area between 1940 and 2000 was 48 ha. 
Table 11. Cover types in valley segments of the geomorphic flood plain, Sprague Valley Basin, Oregon.

[Cover type classes modified from Cowardin and others (1979). Partial aerial photograph coverage for the South Fork and North Fork segments in 1940. Totals may not sum due to rounding. Abbreviation: ha, hectare]

\begin{tabular}{|c|c|c|c|c|c|c|}
\hline $\begin{array}{l}\text { Valley segment } \\
\text { cover type }\end{array}$ & $\begin{array}{c}\text { Chiloquin } \\
\text { Canyon }\end{array}$ & Braymill & $\begin{array}{l}\text { Kamkaun } \\
\text { Spring }\end{array}$ & $\begin{array}{l}\text { S'Ocholis } \\
\text { Canyon }\end{array}$ & $\begin{array}{l}\text { Buttes of } \\
\text { the Gods }\end{array}$ & $\begin{array}{c}\text { Council } \\
\text { Butte }\end{array}$ \\
\hline \multicolumn{7}{|c|}{1940 Area (ha) } \\
\hline Water & 47.7 & 21.6 & 98.0 & 54.9 & 103.4 & 200.4 \\
\hline Bare & 2.4 & 0.3 & 5.8 & 2.8 & 13.6 & 7.9 \\
\hline Herbaceous & 33.4 & 13.1 & 631.0 & 141.2 & 802.2 & $1,374.9$ \\
\hline Short woody & 18.6 & 17.8 & 80.5 & 65.1 & 9.1 & 12.2 \\
\hline Tall woody & 10.6 & 8.7 & 2.0 & 13.5 & 0.0 & 0.6 \\
\hline \multicolumn{7}{|c|}{1968 Area (ha) } \\
\hline Water & 49.1 & 22.3 & 116.4 & 64.5 & 108.0 & 178.0 \\
\hline Bare & 1.4 & 1.4 & 14.0 & 8.5 & 16.5 & 39.0 \\
\hline Herbaceous & 33.7 & 12.8 & 622.4 & 140.0 & 799.5 & $1,375.9$ \\
\hline Short woody & 13.0 & 14.0 & 61.7 & 49.1 & 4.2 & 3.0 \\
\hline Tall woody & 15.6 & 11.0 & 2.8 & 15.3 & 0.0 & 0.0 \\
\hline \multicolumn{7}{|c|}{2000 Area (ha) } \\
\hline Water & 46.5 & 22.6 & 111.9 & 50.6 & 91.5 & 156.6 \\
\hline Bare & 0.8 & 0.4 & 12.9 & 4.3 & 7.5 & 14.5 \\
\hline Herbaceous & 32.8 & 12.8 & 634.3 & 150.2 & 824.6 & $1,423.8$ \\
\hline Short woody & 16.0 & 14.4 & 55.7 & 50.0 & 4.6 & 1.1 \\
\hline Tall woody & 16.7 & 11.4 & 2.5 & 22.4 & 0.0 & 0.0 \\
\hline Total analysis area & 112.8 & 61.5 & 817.3 & 277.5 & 928.2 & $1,595.9$ \\
\hline $\begin{array}{l}\text { Valley segment } \\
\text { cover type }\end{array}$ & $\begin{array}{l}\text { Beatty- } \\
\text { Sycan }\end{array}$ & $\begin{array}{l}\text { Beatty } \\
\text { Gap }\end{array}$ & $\begin{array}{l}\text { Upper } \\
\text { Valley }\end{array}$ & $\begin{array}{l}\text { South } \\
\text { Fork }^{1}\end{array}$ & $\begin{array}{l}\text { North } \\
\text { Fork }^{2}\end{array}$ & $\begin{array}{l}\text { Lower } \\
\text { Sycan }\end{array}$ \\
\hline \multicolumn{7}{|c|}{1940 Area (ha) } \\
\hline Water & 41.2 & 22.7 & 10.7 & 4.6 & 11.1 & 27.8 \\
\hline Bare & 4.1 & 2.7 & 1.2 & 0.8 & 2.5 & 4.0 \\
\hline Herbaceous & 345.1 & 109.3 & 386.6 & 253.8 & 246.5 & 151.4 \\
\hline Short woody & 14.7 & 69.4 & 48.9 & 0.4 & 31.7 & 53.8 \\
\hline Tall woody & 0.0 & 9.8 & 0.0 & 0.0 & 0.0 & 1.2 \\
\hline \multicolumn{7}{|c|}{1968 Area (ha) } \\
\hline Water & 42.8 & 32.3 & 12.6 & 28.1 & 22.6 & 33.4 \\
\hline Bare & 7.1 & 6.5 & 3.4 & 15.3 & 28.1 & 12.3 \\
\hline Herbaceous & 344.0 & 114.8 & 414.0 & $2,122.4$ & 451.7 & 167.7 \\
\hline Short woody & 11.1 & 54.7 & 17.3 & 7.7 & 21.4 & 24.4 \\
\hline Tall woody & 0.0 & 5.6 & 0.0 & 0.4 & 0.3 & 0.4 \\
\hline \multicolumn{7}{|c|}{2000 Area (ha) } \\
\hline Water & 34.1 & 25.2 & 11.9 & 23.2 & 20.7 & 29.5 \\
\hline Bare & 5.1 & 3.3 & 1.5 & 9.4 & 5.3 & 7.6 \\
\hline Herbaceous & 354.0 & 116.2 & 421.7 & $2,138.9$ & 489.2 & 183.6 \\
\hline Short woody & 11.9 & 63.0 & 12.1 & 1.9 & 8.5 & 17.1 \\
\hline Tall woody & 0.0 & 6.1 & 0.0 & 0.5 & 0.5 & 0.5 \\
\hline Total analysis area & 405.1 & 213.9 & 447.3 & $2,173.8$ & 524.1 & 238.2 \\
\hline
\end{tabular}

${ }^{1} 1940$ coverage of South Fork totals 259.6 ha.

${ }^{2} 1940$ area only 291.8 ha. 

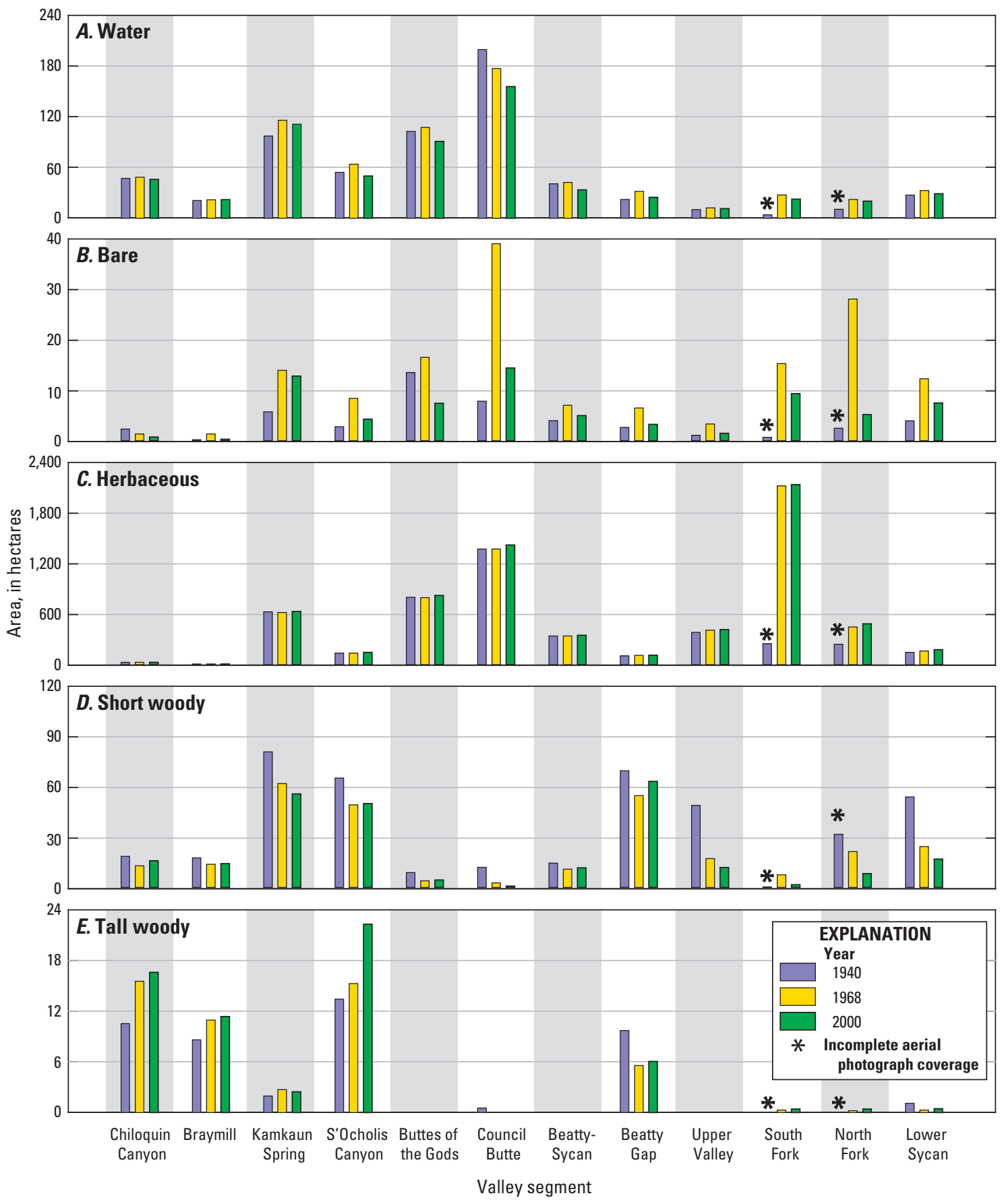

Figure 61. Extent of mapped cover types in the geomorphic flood plain, summarized by valley segment, Sprague Valley Basin, Oregon. 
Table 12. Cover types in valley segments of the near-channel area, Sprague Valley Basin, Oregon.

[Cover type classes are modified from Cowardin and others (1979). Partial aerial photograph coverage for the South Fork and North Fork segments in 1940. Totals may not sum due to rounding. Abbreviation: ha, hectare]

\begin{tabular}{|c|c|c|c|c|c|c|}
\hline $\begin{array}{l}\text { Valley segment } \\
\text { cover type }\end{array}$ & $\begin{array}{c}\text { Chiloquin } \\
\text { Canyon }\end{array}$ & Braymill & $\begin{array}{c}\text { Kamkaun } \\
\text { Spring }\end{array}$ & $\begin{array}{l}\text { S'Ocholis } \\
\text { Canyon }\end{array}$ & $\begin{array}{l}\text { Buttes of } \\
\text { the Gods }\end{array}$ & $\begin{array}{c}\text { Council } \\
\text { Butte }\end{array}$ \\
\hline \multicolumn{7}{|c|}{1940 Area (ha) } \\
\hline Water & 47.7 & 21.6 & 80.1 & 51.8 & 82.0 & 149.0 \\
\hline Bare & 1.4 & 0.0 & 1.5 & 1.3 & 3.0 & 5.5 \\
\hline Herbaceous & 12.5 & 4.3 & 68.9 & 26.6 & 75.6 & 119.0 \\
\hline Short woody & 12.3 & 12.1 & 30.7 & 26.9 & 4.2 & 5.4 \\
\hline Tall woody & 2.7 & 1.9 & 0.1 & 4.9 & 0.0 & 0.0 \\
\hline \multicolumn{7}{|c|}{1968 Area (ha) } \\
\hline Water & 49.1 & 22.1 & 84.6 & 56.3 & 81.5 & 130.9 \\
\hline Bare & 1.1 & 0.3 & 6.1 & 5.0 & 9.1 & 18.2 \\
\hline Herbaceous & 13.8 & 4.8 & 73.1 & 29.7 & 68.7 & 107.0 \\
\hline Short woody & 9.4 & 10.3 & 16.0 & 20.8 & 0.8 & 0.3 \\
\hline Tall woody & 4.0 & 2.7 & 0.5 & 4.9 & 0.0 & 0.0 \\
\hline \multicolumn{7}{|c|}{2000 Area (ha) } \\
\hline Water & 46.3 & 22.5 & 83.2 & 48.3 & 70.4 & 114.1 \\
\hline Bare & 0.4 & 0.1 & 5.9 & 2.4 & 4.8 & 5.8 \\
\hline Herbaceous & 13.6 & 5.3 & 75.0 & 31.5 & 71.8 & 115.0 \\
\hline Short woody & 11.9 & 10.1 & 10.8 & 21.0 & 0.3 & 0.2 \\
\hline Tall woody & 4.0 & 2.5 & 0.6 & 4.9 & 0.0 & 0.0 \\
\hline Total analysis area & 76.7 & 40.0 & 181.4 & 111.5 & 164.7 & 278.9 \\
\hline $\begin{array}{l}\text { Valley segment } \\
\text { cover type }\end{array}$ & $\begin{array}{l}\text { Beatty- } \\
\text { Sycan }\end{array}$ & $\begin{array}{l}\text { Beatty } \\
\text { Gap }\end{array}$ & $\begin{array}{l}\text { Upper } \\
\text { Valley }\end{array}$ & $\begin{array}{l}\text { South } \\
\text { Fork }^{1}\end{array}$ & $\begin{array}{l}\text { North } \\
\text { Fork }^{2}\end{array}$ & $\begin{array}{l}\text { Lower } \\
\text { Sycan }\end{array}$ \\
\hline \multicolumn{7}{|c|}{1940 Area (ha) } \\
\hline Water & 32.0 & 20.4 & 7.8 & 4.0 & 8.9 & 26.5 \\
\hline Bare & 1.3 & 1.5 & 0.9 & 0.0 & 0.7 & 3.1 \\
\hline Herbaceous & 31.6 & 19.5 & 17.0 & 9.6 & 18.4 & 24.5 \\
\hline Short woody & 7.0 & 23.9 & 10.4 & 0.2 & 12.7 & 20.6 \\
\hline Tall woody & 0.0 & 3.0 & 0.0 & 0.0 & 0.0 & 0.7 \\
\hline \multicolumn{7}{|c|}{1968 Area (ha) } \\
\hline Water & 27.3 & 23.8 & 11.3 & 21.0 & 14.6 & 26.3 \\
\hline Bare & 2.4 & 4.3 & 2.0 & 5.8 & 8.9 & 9.9 \\
\hline Herbaceous & 27.4 & 22.9 & 20.8 & 54.0 & 34.8 & 32.4 \\
\hline Short woody & 3.3 & 16.1 & 3.2 & 1.0 & 9.0 & 6.7 \\
\hline Tall woody & 0.0 & 2.0 & 0.0 & 0.0 & 0.1 & 0.0 \\
\hline \multicolumn{7}{|c|}{2000 Area (ha) } \\
\hline Water & 26.0 & 21.0 & 10.1 & 15.7 & 14.1 & 23.4 \\
\hline Bare & 2.0 & 1.9 & 1.1 & 1.8 & 2.8 & 6.0 \\
\hline Herbaceous & 29.2 & 25.7 & 22.9 & 58.7 & 48.6 & 39.3 \\
\hline Short woody & 3.2 & 14.7 & 2.0 & 0.2 & 2.9 & 3.9 \\
\hline Tall woody & 0.0 & 1.6 & 0.0 & 0.0 & 0.0 & 0.2 \\
\hline Total analysis area & 71.9 & 68.2 & 36.1 & 82.2 & 67.3 & 75.4 \\
\hline
\end{tabular}

${ }^{1} 1940$ coverage of South Fork totals 259.6 ha.

${ }^{2} 1940$ area only 291.8 ha. 

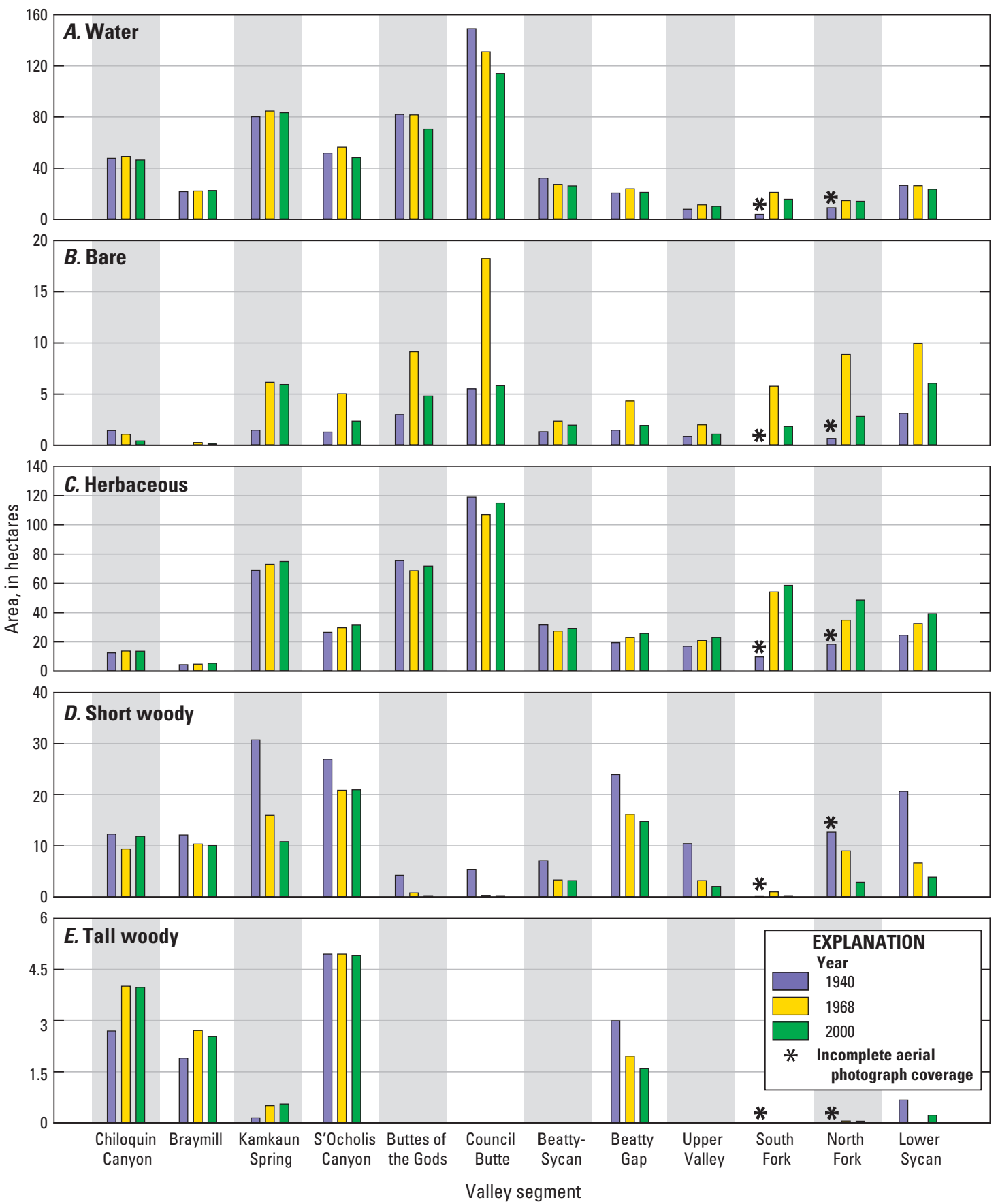

Figure 62. Extent of mapped cover types in the near-channel area, summarized by valley segment, Sprague Valley Basin, Oregon. 
Most large changes in cover type were widespread (table 11, fig. 61). In particular, decreases in short woody cover occurred in all valley segments between 1940 and 1968 (except for the South Fork valley segment, for which aerial photograph coverage in 1940 includes only 12 percent of the analysis area). Likewise, all valley segments except Chiloquin Canyon gained herbaceous cover during 1968-2000. Partly in conjunction with the gain in herbaceous cover, nearly all valley segments lost water and bare are areas during the 1968-2000 period.

As a percentage of flood-plain area, the more confined valley segments of Chiloquin Canyon, Braymill, S'Ocholis Canyon, and Beatty Gap had similarly large losses of short woody cover, with each of these valley segments having reductions of between 5 and 7 percent of short woody cover between 1940 and 1968 (table 11). These decreases, however, were matched or exceeded by the 7 percent decrease in short woody vegetation in the Upper Valley segment and the 12 percent decrease in the Lower Sycan valley segment between 1940 and 1968. Both of these valley segments had substantial expansions of herbaceous cover during this same time period. Changes as a percentage of flood-plain area generally were smaller during the 1968-2000 period, with only two valley segments showing any cover-type change greater than 5 percent during the more recent analysis period compared to 6 of the 10 segments with such changes during the 1940-1968 period.

The temporal trends in the near-channel area for the main-stem Sprague River (excluding the North and South Forks) and Lower Sycan River were similar to trends for the entire flood plain, but with greater fluctuations in water, bare, and short woody cover types (table 12; fig. 62). The difference in water and bare cover types partly represents the higher water levels during acquisition of the 1968 aerial photographs and the bar growth during the December 26, 1964 flooding. The loss of short woody vegetation, however, matches the long-term trend for the entire flood plain, although the relative magnitude is even greater for the near-channel area, where the total area decreased by nearly 50 percent, from 154 ha (14 percent of the near-channel area) in 1940 to 87 ha (8 percent of the near-channel area) in 2000. Most of this decrease was during the 1940-1968 period, when 67 ha were lost. Documented loss of short woody vegetation would have been larger if the North Fork and South Fork valley segments were included in these tabulations; despite the incomplete aerial photographic coverage for 1940, declines in short woody vegetation cover are evident for those segments as well, particularly for 1968-2000 period of complete aerial photograph coverage.

Like the entire flood plain, all valley segments (except the South Fork) had a net loss of short woody cover in near-channel areas between 1940 and 2000. The greatest relative losses (exceeding 50 percent of the 1940 area) were in the Kamkaun Spring, Buttes of the Gods, Council Butte,
Beatty-Sycan, Upper Valley, North Fork, and Lower Sycan valley segments (table 12, fig. 62). A similar reduction likely affected the South Fork valley segment except that the 1940 photograph coverage is incomplete. Compared to most other valley segments, Beatty Gap had a smaller relative loss of short woody vegetation between 1940 and 2000, but this segment also had a nearly 50 percent loss in tall woody vegetation in the near-channel area during this time period.

\section{Vegetation Transitions}

Although temporal and spatial trends can hint at controlling processes, information on the site-specific changes of cover types supports more specific interpretations. A transition matrix analysis identifies all of the possible changes in land cover classes, allowing determination of transitions that are most prevalent during different time periods. Such transitions can be related to successional processes as well as human and natural disturbances. Transition matrix analysis has been used in landscape scale investigations of land use (Petit and others, 2001), grassland and woodland interactions (Hibbard and others, 2003), and dune and delta environments (Shanmugam and Barnsley, 2002; Biondini and Kandus, 2006).

This analysis evaluated the change in mapped cover type for each square meter of flood plain between 1940 and 1968 (appendix table H1) and between 1968 and 2000 (appendix table $\mathrm{H} 2$ ). For each analysis period, cover changes were recorded as 1 of 21 transitions, accounting for the 20 possible transitions of one cover type to another plus that of "No Change." As for the general cover-type characterization, the transition analysis also was conducted for the near-channel area composed of the $20 \mathrm{~m}$ extending laterally in each direction from the channel centerline (appendix tables H3, H4). For the near-channel transition analysis, the analysis area remained fixed about the 1940 centerline, except for where 1940 aerial photograph coverage was unavailable upstream of FK 95.2 on the South Fork valley segment and upstream of NFFK 5.8 on the North Fork valley segment. For the upstream parts of these valley segments, the transition analysis was restricted to the 1968-2000 time period for the near-channel area flanking the 1968 channel centerline.

For both time periods (1940-1968 and 1968-2000), more than 90 percent of the flood-plain surface within the analysis area did not change cover type (appendix tables H1, H2). Nevertheless, the confined segments were more dynamic, with about 20 percent or more of the flood plains in each of the Chiloquin Canyon, Braymill, S'Ocholis Canyon, Beatty Gap, and Lower Sycan valley segments changing cover classes during each of the analysis periods (fig. 63). Vegetation classes in the unconfined valley segments remained unchanged for about 90 percent of the flood-plain areas. The South Fork valley segment was the most static, with 98 percent of its flood plain remaining the same cover type for the 1968-2000 period. 


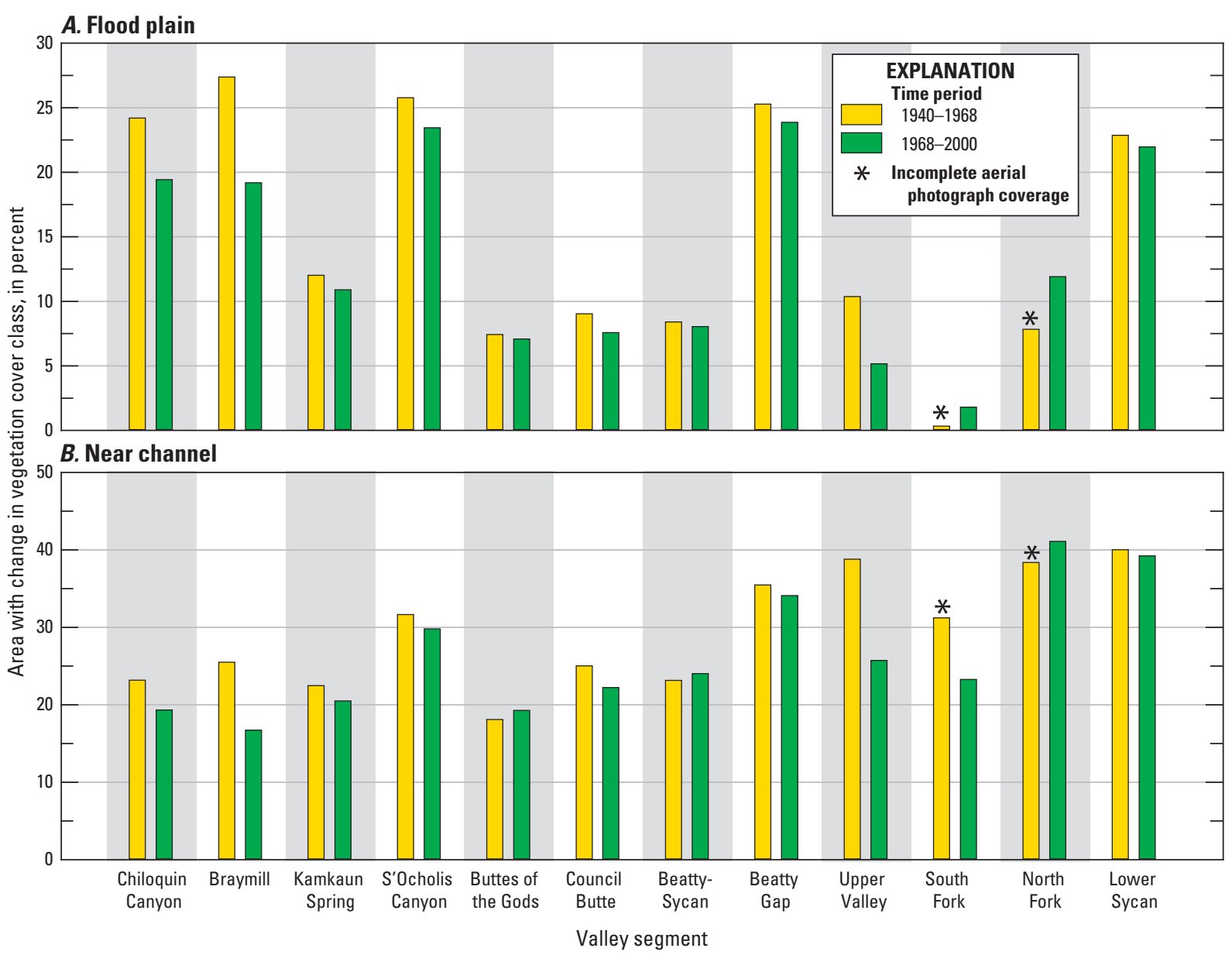

Figure 63. Percentage of valley segment area in which cover type changed in $(A)$ entire geomorphic flood plain, and (B) near-channel area, Sprague River Basin, Oregon, during 1940-1968 and 1968-2000 analysis periods.

The near-channel area was more dynamic than the flood plain as a whole, with 25 percent of the area changing cover class during the 1968-2000 period (27 percent between 1940 and 1968) (appendix tables H3, H4; fig. 63). These higher near-channel rates explain the relatively high rates of total flood plain transitions in the confined reaches (fig. 63A), where the near-channel areas constitute a greater percentage of the flood-plain area. The most dynamic valley segments in terms of near-channel vegetation transition were the Lower Sycan and North Fork valley segments, where about 40 percent of the near-channel area changed cover classes during both analysis periods. The Upper Valley, Beatty Gap, and S'Ocholis Canyon valley segments also had more than 25 percent of the near-channel area-change cover types during both analysis periods. The valley segments with the most consistently stable near-channel vegetation cover class were the Buttes of the Gods, Chiloquin Canyon, and Braymill segments, for which less than 20 percent of near-channel area changed during the 1968-2000 analysis period.

Examination of the individual transition categories also reveals trends (figs. 64, 65), clarifying changes evident from the overall change analysis. The greatest changes for both time periods (1940-1968 and 1968-2000) and for both the entire flood-plain and near-channel areas involved cover-type transitions between (1) short woody and herbaceous, (2) water and herbaceous, and (3) water and short woody. In particular, for the 1940-1968 period, nearly every segment showed substantial conversion from short woody to herbaceous and short woody to water. For the 1968-2000 period, these particular transitions were more balanced. 


\section{A. 1940-1968}

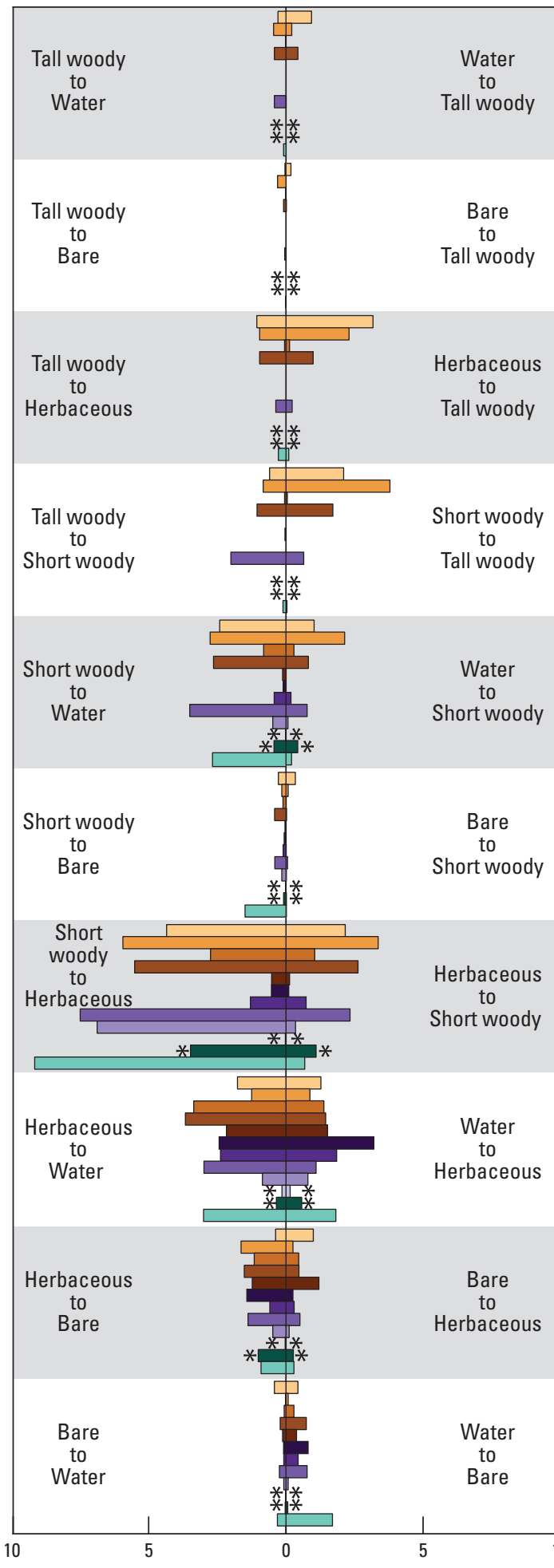

\section{B. 1968-2000}

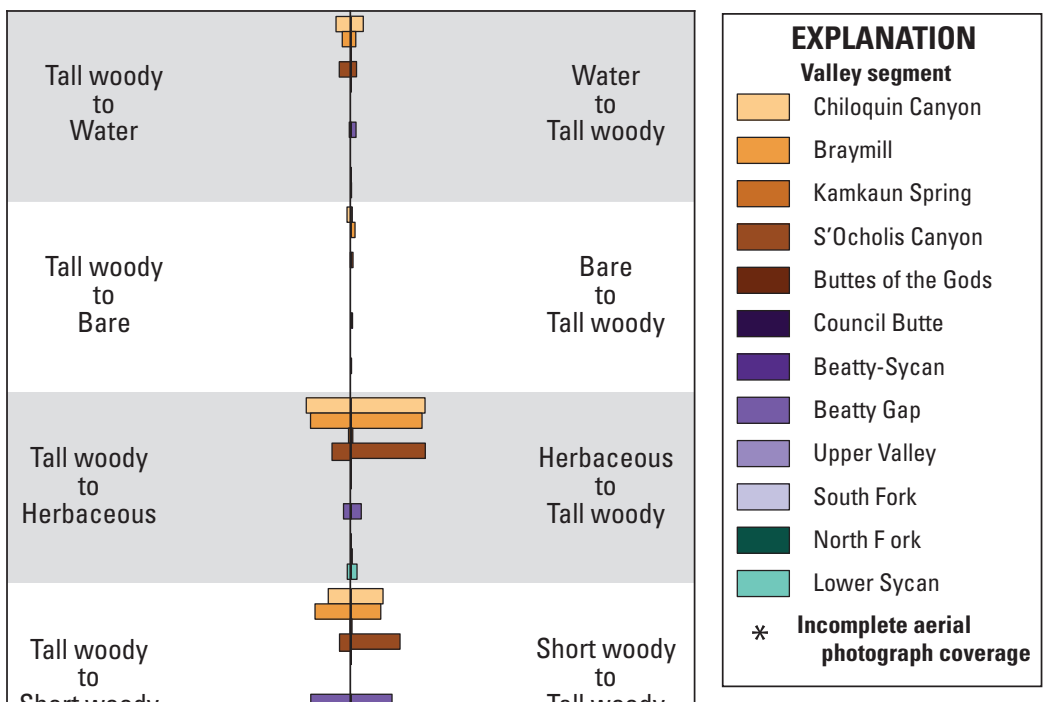

Cover type transition, in percent

Figure 64. Cover-type transitions for geomorphic flood plain, summarized by valley segment, during $(A)$ 1940-1968 (analysis area limited in South Fork and North Fork valley segments by incomplete 1940 aerial photograph coverage), and (B) 1968-2000, Sprague River Basin, Oregon. Transitions to the right of the vertical lines generally represent increasing seral stage and structural complexity. 


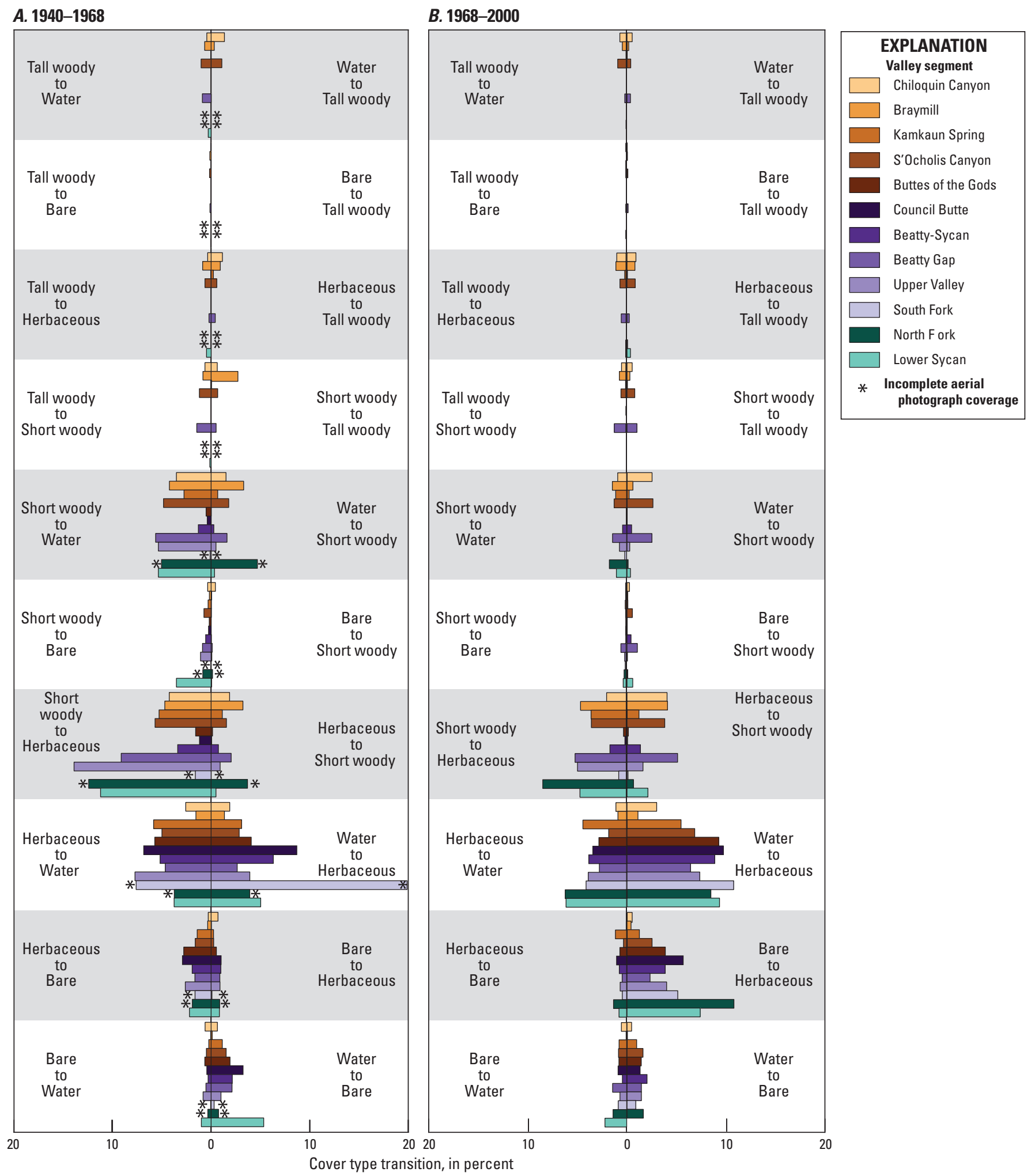

Figure 65. Cover-type transitions for the 40-meter-wide, near-channel zone centered about 1940 channel centerline (1968 centerline for South Fork and North Fork valley segments for 1968-2000), summarized by valley segment, during $(A)$ 1940-1968, and (B) 1968-2000, Sprague River Basin, Oregon. Transitions to the right of the vertical lines generally represent increasing seral stage and structural complexity. 
Other pronounced transitions include the widespread transition of bare to herbaceous and water to herbaceous in the 1968-2000 period, again representing the lower water level shown in the 2000 aerial photographs and the greater area of bars in the 1968 photographs (figs. 64, 65). Also evident is the widespread conversion of the tall woody cover class to other cover types during the 1968-2000 period. This trend is apparent only for the flood plain as a whole and is not evident in the near-channel area, indicating that most of the loss of tall woody vegetation was in areas away from the channel.

These transitions can be viewed with respect to successional pathways and vegetative structural complexity. In the absence of disturbance, the expected successional progression is bare to herbaceous to short woody to tall woody. This progression also generally results in increasing structural complexity, involving increasing diversity of plant types, plant heights and habitat heterogeneity. Movement in the opposite direction typically requires some sort of disturbance. From this perspective, cover-type transitions to the right of the central vertical lines in figures 64 and $\underline{65}$ indicate increasing seral stage and structural complexity, whereas those to the left indicate decreasing seral stage and complexity, likely resulting from site disturbances or erosion. Therefore, the aerial photograph analysis generally shows decreasing seral stage for most possible transitions for the 1940-1968 period for the flood-plain and the near-channel corridor, particularly for areas covered by short woody vegetation in 1940. For the 1968-2000 period, the analysis of the flood plain shows systematic decreasing seral stage associated with tall woody vegetation, but herbaceous growth in many areas that were either bare or underwater in 1968. Many valley segments also had conversions from herbaceous to short woody vegetation. Findings generally were similar for the 1968-2000 period in the near channel area, aside from little evidence for the decreasing tall woody cover class seen at the flood-plain scale.

Summarizing the transitions by increasing and decreasing seral stage for each valley segment shows that, for all valley segments, the relative area of decreasing seral stage was greater in the 1940-1968 period than in the 1968-2000 period for both the flood-plain and near-channel areas (ig. 66).

However, 1940-1968 decreases generally were greater in the near-channel areas, particularly for the $\mathrm{S}^{\prime}$ Ocholis Canyon, Beatty Gap, Upper Valley, and Lower Sycan valley segments. The Beatty Gap and Lower Sycan valley segments also had large net decreases in seral stage when considering the entire flood-plain area. Many of these segments with substantial 1940-1968 decreases, however, had net increases in seral stage for the 1968-2000 period, especially the S'Ocholis Canyon, Beatty Gap, and Lower Sycan valley segments.

\section{Major Vegetation Changes and Their Causes}

These vegetation cover-type changes - in conjunction with understanding of successional processes, land-use, and channel and flood-plain dynamics - allow for the inference of the key factors controlling present vegetation patterns and recent trends in the Sprague River study area. Beyond this, Rasmussen (2011) provides more specific information on relations between channel, soil moisture, land-use, and riparian vegetation processes in the Sprague River study area.

\section{Transitions Among Water, Bare, and Herbaceous Cover Classes}

Variations and transitions among these cover classes owe chiefly to changes in channel pattern, inundation, and disturbance. Historical observations and the aerial photograph analyses show that the flood plains, especially for the unconfined segments, were vegetated mostly by herbaceous species (figs. 61, 62). Therefore, transitions involving herbaceous cover tend to occupy larger areas than for other cover types. Transitions between water and herbaceous cover types result primarily from (1) channel movement, either by lateral erosion or avulsion, into flood-plain areas covered by herbaceous vegetation; (2) inundation of areas covered by herbaceous vegetation; (3) excavation of ditches and storage ponds; and (4), in the other direction, emergence or colonization of herbaceous vegetation in areas formerly covered by water. All these processes probably were important in the analysis area. The total net reduction in water-covered area between 1940 and 2000, mainly resulting from decreased channel sinuosity, accounts for 29 percent of the increase in herbaceous area in the region during this period (appendix tables H1, H2). Furthermore, the lower water levels in the 2000 aerial photographs compared to those of the 1968 photographs is the chief reason for the substantial transition of water cover to herbaceous cover between 1968 and 2000 (figs. 64 and 65), although the 1-6 percent of the near-channel area that changed from herbaceous cover to water cover during this time period likely represents channel migration.

Bare areas indicate recent disturbance. This is most evident in the substantial increase in bare area shown by the 1968 aerial photographs, particularly in the near-channel areas (figs. 61, 62). This is consistent with the increased bar area at this time (fig. 38) and almost certainly represents erosion and deposition during December 1964 flooding, primarily in areas formerly covered by herbaceous vegetation. Some bare areas, however, are created and maintained by livestock trampling, roads, and water access paths (fig. 67). The consistent reduction of bare area and conversion of bare cover to herbaceous cover in the Chiloquin Canyon valley segment likely represents less land disturbance resulting from mill closure. 


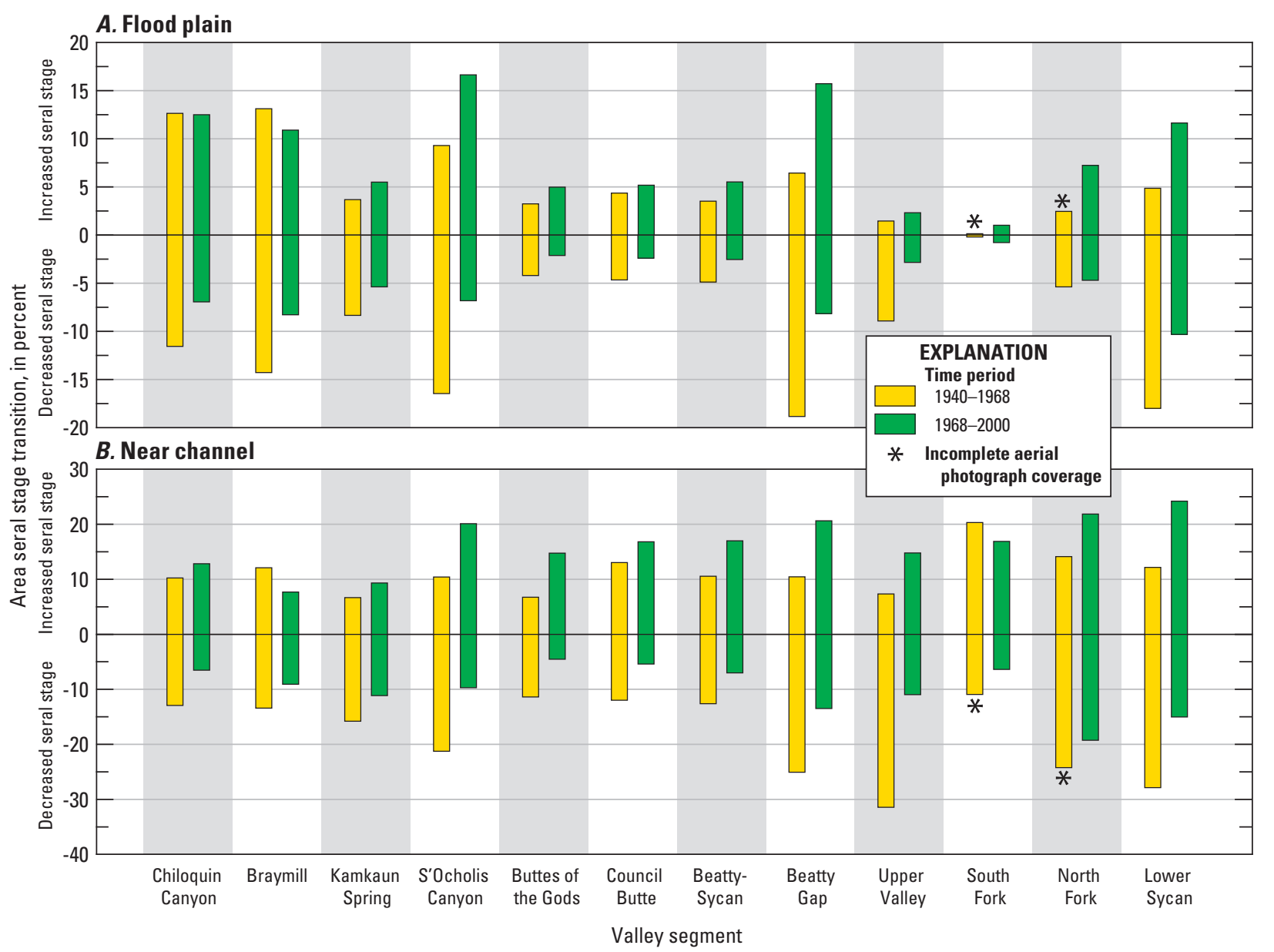

Figure 66. Summary of seral stage trends in $(A)$ entire geomorphic flood plain, and $(B)$ near-channel area, Sprague River Basin, Oregon, during 1940-1968 and 1968-2000.

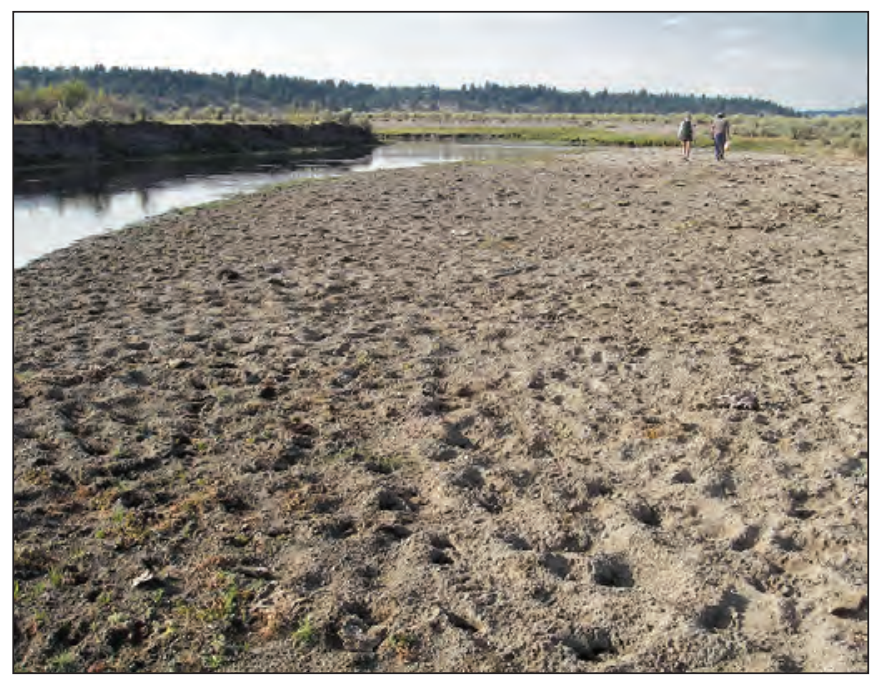

Figure 67. Trampled sand-and-gravel point bar looking upstream near Sycan River flood-plain kilometer 0.1 along Sycan River, Oregon. Photograph taken by J.E. O'Connor, U.S. Geological Survey, September 12, 2007. 


\section{Short Woody Vegetation}

Historical observations noted willow and currant along the channel throughout the study area, including small amounts in the unconfined valley segments otherwise vegetated mainly by herbaceous cover types. Short woody vegetation has decreased substantially since those historical observations, particularly in the Beatty-Sycan, Upper Valley, and South Fork valley segments where William E. Lawrence recorded conditions in the early 1900s. This trend has continued for several valley segments during the 1940-2000 photograph analysis period when the area of short woody vegetation decreased by 38 percent in the flood plain and by 50 percent in the near-channel area (appendix tables $\mathrm{H} 1-\mathrm{H} 4$ ).

Most of these losses were in the 1940-1968 time period and involved transitions to herbaceous, water, and bare cover types (figs. 64, 65). For the Lower Sycan valley segment, these three transitions encompassed 20 percent of the near-channel area. These vegetation changes all represent decreases in seral stage, indicating active disturbance processes. Additionally, short woody vegetation in 1940 formed large patches, with no apparent preference for near-channel zones. Patches were much smaller and much more fragmented in 1968 than in 1940. Subsequent to 1968 , the area occupied by short woody cover continued to decrease, but by a much smaller fraction, and many valley segments gained more short woody cover from succession from water, bare, and herbaceous cover types than was lost by disturbance.

Many factors probably account for the decrease in short woody vegetation. Areas of transition from short woody cover to water and bare cover probably represent, at least in part, fluvial erosion of riparian shrubs from channel margins. However, as described for other montane environments (Schulz and Leininger, 1990; Green and Kauffman, 1995; Holland and others, 2005), livestock trampling and grazing also are likely factors in reducing the area of short woody vegetation, especially in the many areas where losses resulted from shrinking and fragmentation of short woody vegetation patches (instead of complete removal, which would result from mechanical conversion to pastureland). This transition from short woody cover to bare cover accounts for 21-40 percent of the near-channel areas losing short woody cover between 1940 and 1968, with the largest losses in the confined Chiloquin Canyon, Braymill, and S'Ocholis Canyon valley segments. Some unknown part of this change owes to the higher water levels of 1968 , but the $2-18$ percent of the near-channel areas that transitioned from short woody cover to bare cover between 1940 and 1968 almost certainly resulted from fluvial erosion, except for isolated locations of human disturbance.

The transition from short woody cover to herbaceous cover was the most frequent transition associated with loss of short woody cover for all valley segments for both the 1940-1968 and 1968-2000 time periods, and for both the near-channel area and entire flood plain. For near-channel areas, this transition accounted for $40-70$ percent of the loss in each valley segment for 1940-1968 and 64-91 percent for 1968-2000. This transition was even a larger factor for the entire flood plain, accounting more than 90 percent of the short woody vegetation loss for several of the wider and unconfined valley segments. In near-channel areas, this transition can also be due to fluvial erosion and subsequent colonization of bare surfaces by herbaceous vegetation. But the widespread transition of short woody cover to herbaceous in flood-plain areas away from the near-channel zone indicates that fluvial erosion was likely not a major factor. More likely is that conversion to pasture and agriculture contributed to the loss of short woody vegetation on flood plains. Additionally, livestock grazing and mechanical removal (as was the case for willow removal along the Sprague River during the 1950s and 1960s) can convert short woody cover to herbaceous (Schultz and Leininger 1990; Green and Kauffman 1995; Holland and others, 2005). Both of these activities have probably been significant contributors to the loss of short woody vegetation in the Sprague River Basin, particularly between 1940 and 1968.

Other factors possibly contributing to the decrease in short woody cover are disease, insects, and predation by wildlife. After sustained high water in spring 2006, willow stands across much of the basin were infected with a rust fungus during the following growing season. Leaves yellowed and fell in mid-season, although they re-foliated normally the following spring. Predation by beaver and muskrat is prevalent throughout the study area, although it is greatest in patches in the near-channel zone. Isolated shrubs and small willow patches in the wide flood-plain segments can be decimated by beaver predation where activity is concentrated. Over time, these local pressures on shrub growth may become evident at the level mapped in this study, although their present effects are unknown.

\section{Tall Woody Vegetation}

Tall woody vegetation typically is sparser than all other cover types in the study area, and was not present in 2000 for the Buttes of the Gods, Beatty-Sycan, and Upper Valley segments (table 11; fig. 61). However, in the Chiloquin Canyon, Braymill, and S'Ocholis Canyon segments, tall woody cover has increased by 32-66 percent between 1940 and 2000. Most of the increase has been from water, herbaceous and short woody cover types, indicating general succession in these historically timbered flood-plain sections.

In the Beatty Gap valley segment, however, tall woody cover has decreased from 9.8 ha to 6.1 ha between 1940 and 2000 (appendix H tables H1, H2; fig. 61). About 40 percent of the loss was from the near-channel area (fig. 62). A small part of the decline in tall woody cover resulted from tall woody cover areas transitioning to water (particularly between 1940 and 1968), probably from fluvial erosion of timbered stands (fig. 28). However, 75 percent of the net decrease in tall woody vegetation resulted from transition to short woody 
cover types, particularly in the near-channel area between 1940 and 1968 and for the broader flood plain between 1968 and 2000. This transition possibly owes to dieback of aspen patches. Recent losses from the near-channel area may be from beaver, for which there was evidence of active felling during the 2006 synoptic survey.

\section{Summary of Flood-Plain and Near-Channel Vegetation Conditions}

Broadscale basin characteristics strongly influence the general spatial patterns of vegetation in the Sprague River flood plain. These patterns, as mapped from the 2000 aerial photographs, are similar to those recorded by the first government surveys in the 1800s. Tall woody species prefer narrow, confined, and shaded flood plains; wide flood plains mostly are covered with herbaceous plants, but past and present channel areas locally are flanked by short woody vegetation. These predominant attributes have remained constant since the first historical observations, chiefly because the areas within the study area have remained generally pastoral without substantial urbanization, timber harvest (within the flood plain), or changes in flow and sediment regimes.

The assessment of the 1940-2000 aerial photographs, however, shows that at finer scales near-channel areas are more dynamic than the flood plain as a whole. About 25 percent of the near-channel area changed cover class during each 28-32-yr analysis period, compared to only 10 percent for the flood plain. The greater vegetation dynamics of the near-channel area indicate the important roles of fluvial disturbance and succession in creating riparian vegetation communities, perhaps exacerbated by predation and concentrated grazing.

Despite the general stability of overall vegetation patterns, clear trends are evident among individual cover types. The most systematic and broadscale change has been the loss of short woody vegetation - only one-half of the nearchannel area covered by short woody vegetation in 1940 was similarly covered in 2000 . The loss of short woody vegetation to less complex early seral stages was the major change among many indicating vegetation disturbance and loss of structural complexity. These changes were most prevalent prior to 1968. In the 1940-1968 period, the Kamkaun Spring, S'Ocholis Canyon, Beatty Gap, Upper Valley, and Lower Sycan valley segments generally showed the greatest decreases in seral stage. The North Fork and South Fork valley segments also likely lost short woody vegetation during this period, but quantitative information is not available prior to 1968. Since 1968, overall vegetation trends are not as strong except for (1) continued loss of short woody cover in all valley segments upstream of the confluence of the Sycan and Sprague Rivers,

(2) loss of bare area in nearly all valley segments, and

(3) increase in tall woody vegetation in the Chiloquin Canyon and Braymill valley segments.
These changes have resulted from a combination of geomorphic processes and trends, vegetation succession, direct vegetation manipulation, and broadscale land-use. Transitions among the bare and water cover types chiefly are the result of decreased sinuosity, different water levels at the time of the aerial photographs, and the December 1964 flooding, which created many bare bar areas evident in the 1968 photographs. Vegetation succession locally has increased seral stage and habitat complexity, partly balancing the effects of disturbance processes, particularly since 1968 . Woody vegetation removal in the 1950s and 1960s and continuing grazing and trampling by livestock probably are the main reasons for the decline of short woody vegetation from the dense riparian corridors of willows and other riparian shrubs noted in the early 20th century.

\section{Implications for Restoration and Monitoring}

As is the case for other rivers (Jaquette and others, 2005; Wohl and others, 2005), understanding of historical conditions, trends, and channel and flood-plain processes can help in the design of effective restoration and monitoring strategies for improving ecological function of the Sprague River fluvial corridor. Consistent with the scale of the analyses in this study, this assessment focuses on broadscale conditions, controls, and approaches, recognizing that some key ecologic issues require attention at local scales and short time frames. This assessment also emphasizes physical conditions, following the premise that geologic, geomorphic, and hydrologic processes provide the basic physical framework in which ecologic systems operate.

\section{Status and Trends}

Knowledge of present conditions and historical trends can clarify restoration objectives, opportunities, and constraints for the Sprague River study area (table 13). Most importantly, most physical processes that have formed the present channel and flood plain still substantially operate at the basin scale. Essential flow and sediment transport conditions have not been significantly changed, although such processes are dynamic and controlled by basin-scale factors such as climate, sediment production, and possibly land use. Therefore, key processes of lateral and longitudinal connectivity remain active. This contrasts with many western rivers in which dams and diversions have affected basin-scale sediment and water fluxes, and where channel incision has limited interaction between channels and flood plains. Because these overall basin conditions have not been altered significantly, the historical conditions prior to extensive flood-plain and channel modification provide a plausible reference frame for restoration objectives. 
Table 13. General valley segment trends and conditions, with implications for restoration, Sprague River Basin, Oregon

\begin{tabular}{|c|c|c|}
\hline Chiloquin Canyon & Braymill & Kamkaun Spring \\
\hline
\end{tabular}

Important process changes

Minimal, although sediment and woody Minimal debris associated with 2008 Chiloqin Dam removal locally may affect lower part of segment.
Confinement of overbank flows; possibly increased incidence of cutoffs and avulsions associated with flood-plain modifications; locally restricted channel migration by levees and bank protection.

Restoration implications

Natural process regime largely intact; most ecologic goals likely attained by minimizing alterations to geomorphic flood plain, allowing channel migration and riparian vegetation succession; locally dense stands of reed canarygrass may slow natural regeneration of short woody vegetation.
Similar as for Chiloquin Canyon segment.

Natural process regime largely intact; reducing overbank flow confinement by levees, roads, and railroad embankments would promote flood-plain deposition and possibly reduce frequency of avulsions and cutoffs; minimizing bank hardening and promoting channel migration processes likely would increase sinuosity and decrease channel slope over decadal time scales; protection of riparian areas from trampling and excessive browsing likely would increase amount short woody vegetation; channel slope and fluvial energy low, so natural processes slow to modify channel and flood plain conditions. 
Table 13. General valley segment trends and conditions, with implications for restoration, Sprague River Basin, Oregon.-Continued

\begin{tabular}{ccc}
\hline S'Ocholis Canyon & Buttes of the Gods & Council Butte \\
\hline & Major historical changes to flood plain and channel & \\
\hline
\end{tabular}

Decreased channel migration rates; increased Confinement by levees and railroad; tall woody vegetation, decreased short woody vegetation.

vegetation removal and flood-plain cultivation and grazing; increased channel slope; decreased channel migration rates; frequent avulsions and cutoffs; reduced short woody riparian vegetation; local channel remeandering.
Extensive confinement by levees, roads, and railroad; vegetation removal, and flood-plain leveling; flood-plain and riparian cultivation and grazing; increased channel slope; decreased channel width, sinuosity, and migration rates; local incision; reduced short woody riparian vegetation; local channel remeandering.

Important process changes

Minimal
Confinement of overbank flows; possibly increased incidence of cutoffs and avulsions associated with flood-plain modifications; locally restricted channel migration by levees and bank protection.
Local historical incision may reduce frequency and extent of overbank flows; confinement of overbank flows; possibly increased incidence of cutoffs and avulsions associated with flood-plain modifications; locally restricted channel migration by levees and bank protection.

\section{Restoration implications}

Natural process regime largely intact; most ecologic goals likely attained by minimizing alterations to geomorphic flood plain, allowing channel migration and riparian vegetation succession; woody debris derived from riparian vegetation in this segment may be important for downstream habitat and channel structure.
Similar to restoration implications for Kamkaun Spring segment although low banks in this reach do not favor colonization of short woody vegetation.
Natural process regime largely intact; reducing overbank flow confinement by levees, roads, and railroad embankments likely to promote flood-plain deposition and possibly reduce likelihood of future incision and frequency of avulsions and cutoffs; minimizing bank hardening and promoting channel-migration processes likely would increase sinuosity and decrease channel slope; protection of riparian areas from trampling and excessive browsing likely to increase locally amount short woody vegetation although abundant low banks mostly more favorable for riparian herbaceous growth; channel slope and fluvial energy exceptionally low, so natural processes slow to modify channel and flood-plain conditions. 
Table 13. General valley segment trends and conditions, with implications for restoration, Sprague River Basin, Oregon.—Continued

\begin{tabular}{|c|c|c|}
\hline Beatty-Sycan & Beatty Gap & Upper Valley \\
\hline $\begin{array}{l}\text { Local historical incision may reduce } \\
\text { frequency and extent of overbank flows; } \\
\text { confinement of overbank flows; possibly } \\
\text { increased incidence of cutoffs and avulsions } \\
\text { associated with flood-plain modifications; } \\
\text { locally restricted channel migration by levees } \\
\text { and bank protection. }\end{array}$ & $\begin{array}{l}\text { Local historical incision may reduce } \\
\text { frequency and extent of overbank flows; } \\
\text { confinement of overbank flows; possibly } \\
\text { increased incidence of cutoffs and avulsions } \\
\text { associated with flood-plain modifications; } \\
\text { local inhibition of channel migration by } \\
\text { levees; possible decreased abundance of } \\
\text { large in-channel wood. }\end{array}$ & $\begin{array}{l}\text { Local historical incision may reduce } \\
\text { frequency and extent of overbank flows; } \\
\text { confinement of overbank flows; possibly } \\
\text { increased incidence of cutoffs and avulsions } \\
\text { associated with flood-plain modifications; } \\
\text { locally restricted channel migration by levees } \\
\text { and bank protection; possible decreased } \\
\text { abundance of large in-channel wood. }\end{array}$ \\
\hline
\end{tabular}

Restoration implications

Similar to restoration implications for Council Butte valley segment.
Natural process regime largely intact aside from consequences of local incision; most ecologic goals likely attained by minimizing alterations to geomorphic flood plain, protection from incision, and allowing channel migration and riparian vegetation succession; promoting short and tall woody vegetation grown for this segment may have broader consequences because of the role of large wood generated in this segment for downstream in-channel wood supply; more energetic fluvial environment should result in dynamic channel and flood-plain evolution.
Similar to restoration implications for Council Butte valley segment. 
Table 13. General valley segment trends and conditions, with implications for restoration, Sprague River Basin, Oregon.-Continued

\begin{tabular}{|c|c|c|}
\hline South Fork & North Fork & Lower Sycan \\
\hline
\end{tabular}

Important process changes

Conversion from multi-channel wetland to incised single channel; diminished overbank flooding, channel migration; increased sediment entrainment from channel incision and flood-plain erosion; decreased channel interaction with in-channel wood and riparian vegetation.
Local historical incision and confinement may reduce frequency and extent of overbank flows; channel migration locally restricted by levees and bank protection; possible decreased abundance of large in-channel wood; longitudinal connectivity reduced by in-channel diversion structures.
Local historical incision and confinement may reduce frequency and extent of overbank flows; locally restricted channel migration by levees and bank protection; disturbance of Sycan flood surfaces may enhance bank erosion and sediment delivery to channel.

\section{Restoration implications}

Significant historical transformation and incision of this valley segment probably requires active and substantial channel and flood-plain modifications to attain conditions similar to the low-energy wet meadow environment of early historical observations within decadal time frames; interrelated goals to attain historical conditions would include increasing sinuosity and overbank flooding, reducing flow confinement and bank hardening, facilitating processes promoting channel and flood-plain aggradation, increasing riparian vegetation, maintaining high water tables, and possibly promoting beaver colonization.
Natural process regime largely intact aside from consequences of local incision and diversion; most ecologic goals likely attained by minimizing alterations to geomorphic flood plain, protecting flood plains from incision, and allowing channel migration and riparian vegetation succession.
Similar to restoration implications for North Fork, but with specific attention to protecting sandy Sycan flood surfaces from vegetation disturbance and enhanced erosion.

\section{Coyote Bucket}

\begin{tabular}{l} 
Major historical changes to flood plain and channel \\
\hline Minimal \\
\hline \multicolumn{2}{c}{ Important process changes } \\
\hline Minimal Restoration implications \\
\hline Natural process regime largely intact \\
\hline
\end{tabular}


Although most important physical processes still function, systematic trends in channel and flood-plain conditions indicate broadscale human influence. In particular, declining sinuosity, increased channel slope, decreased migration rates, local channel incision, and less short woody vegetation probably are the interrelated consequences of floodplain and channel alterations. Channel confinement by levees and other built features probably is the single most important factor contributing to these changes, but the direct and indirect consequences of other manipulations, such as local flow diversion and concentration, grazing, vegetation removal, and beaver eradication, also have been important, particularly at the valley segment scale. Channel and flood-plain changes, including vegetation, were most evident for the period between 1940 and 1968, coinciding with increased use of heavy equipment for flood control and developing irrigation structures.

The slowing of many of these trends between 1968 and 2000 indicates that reversal is possible and that some channel and flood-plain attributes are potentially restorable to near-pre-development conditions. This is particularly true downstream of the confluence of the North Fork and South Fork Sprague Rivers, where there has been little incision. For this broad area of the Sprague River study area, in which flood flows regularly inundate the flood plain, natural processes may be sufficient to reverse historical broadscale trends, particularly if alterations such as flood-plain confinement, bank trampling, and bank hardening are reversed.

Conditions are different in the eastern valley segments (table 13). Particularly for the South Fork valley segment, and to a lesser degree in the Upper Valley segment and possibly the North Fork valley segment, historical and ongoing channel incision and flood-plain erosion will inhibit reversal of historical trends and likely will continue to be a source of suspended sediment load to the river system. For the South Fork valley segment, incision likely will continue as long as the channel is fully constrained by levees and dikes and until knickzones and other erosional areas progress to locations where channel and flood-plain substrate resists continued downcutting and gully expansion. Current and historical trends are not likely to be reversed until a more natural channel and flood-plain geometry is attained and the channel aggrades to the extent that overbank flow becomes common.

\section{Spatial and Temporal Scales}

The mapping, stratigraphic investigations, and quantitative channel and flood-plain analyses provide context for restoration objectives and approaches to monitoring. Most broadly, the geomorphic flood plain is the domain of nearly all key hydrologic and geomorphic processes shaping the channel and flood plain. Some areas outside the geomorphic flood plain are inundated by flooding, particularly some areas of main-stem valley fill, but only the geomorphic flood plain has been subject to channel-forming processes for the last several thousand years. Therefore, the greatest likelihood of restoration to pre-development conditions would result from a strategy emphasizing natural processes for the entire geomorphic flood plain. Historically, most channel processes operated within narrow corridors; therefore, it may be possible to reverse historical changes in the channel by focusing on more limited areas adjacent to the present channel. Such a strategy, however, carries some risk, since avulsions and cutoffs, which create ecologically important flood-plain features, require access to areas outside the near-channel environment.

The valley segments also provide a spatial context for restoration and monitoring. Conditions, trends, and processes vary significantly among the segments (table 13), and restoration strategies are likely to be most successful if tailored to specific segments and the important processes and conditions within those segments. For example, the fundamental changes to the South Fork valley segment (such as the channel straightening and incision) make it unlikely to recover natural process regimes and morphologies without active manipulation (possibly including relocating the channel and increasing sinuosity), whereas other valley segments likely would achieve high levels of channel and flood-plain function by adoption of more passive strategies such as protection of the riparian corridor and levee breaching.

More broadly, the unconfined and confined segments have different vegetation characteristics, morphologies, and process regimes. Most of the decreases in sinuosity are in the unconfined valley segments (ig. 60), partly because of confinement of these segments locally by levees and railroad grades. All segments have lost short woody vegetation, but percentagewise, the losses have been greatest in the unconfined valley segments, particularly in near-channel areas (figs. 61, 62). The unconfined segments historically and presently had very little woody cover aside for the nowdiminished short-woody riparian species. By contrast, the confined segments along the main-stem Sprague River have more woody vegetation and are the primary sources of large wood to the entire river corridor. These trends and attributes could point to segment-specific restoration objectives for vegetation management.

An important aspect of the Sprague River study area is that geomorphic processes are slow. The low slopes, low bedmaterial supply and transport rates, and low stream powers all result in naturally slow rates of channel and flood-plain evolution. In particular, rates of channel migration, meander enlargement (increasing sinuosity), lateral and vertical flood-plain building, and short woody vegetation recovery are likely to be slow processes under passive management scenarios. Therefore, restoration objectives dependent on natural processes may take longer to achieve than for more energetic and sediment-rich fluvial systems more typical in western North America. 
Sediment and flow regimes have changed naturally in the Sprague River study area over the last several thousand years. These natural dynamics have affected overall flood-plain morphology, and rates and processes of channel movement. At millennial time scales, the Sprague River fluvial system is still responding to the 7,700 cal yr BP eruption of Mount Mazama and the resulting loading of the basin with sand- and granule-size pumice. Over thousands of years, the effects of this sediment will diminish, and, in the absence of a similar large-scale disturbance, it is likely that the Sprague River fluvial system will revert to a more fine-grained wet meadow system as indicated by the character of pre-Mazama flood-plain deposits. At these long time scales, the unconfined valley segments (and adjacent main-stem valley fills) are likely to continue to aggrade slowly from overbank flood-plain deposition and slow channel migration across the flood plain.

At shorter and more relevant time scales for restoration, natural flood plain and channel dynamics are likely to affect channel and flood-plain conditions. In particular, for the North Fork and Lower Sycan valley segments, stratigraphic records show many cycles of flood-plain erosion and deposition over the last 2000 years, including a current phase of flood-plain building over the last 300-600 years. These episodes of flood-plain formation and erosion, possibly in conjunction with minor channel incision and aggradation, likely represent changes in basin sediment and flow conditions, possibly resulting from climate variability (Lind, 2009). Additionally, the North Fork valley segment has apparently alternated between a channelized fluvial corridor and wet meadow fluvial system before attaining its current channel and flood-plain morphology. These dynamics represent natural ranges of behavior and morphology, and could be incorporated into restoration objectives aiming for natural process regimes.

\section{Key Process Regimes}

Because natural variability and complexity are ubiquitous and incompletely understood for physical and ecologic processes and interactions involving rivers, restoration of processes may be more likely to achieve ecologically based rehabilitation goals than would restoration to predefined end points (Wohl and others, 2005; Palmer and others, 2005; Bernhardt and Palmer, 2011). For the Sprague River, we have identified three key and interrelated process regimes historically important to flood-plain and channel form and function: (1) channel migration (including avulsions and cutoffs), (2) overbank flooding, and (3) vegetation succession and disturbance. Maintaining these processes would likely result in long-term channel and flood-plain conditions consistent with regional ecologic objectives (National Research Council, 2004) for much of the study area.

Channel migration builds much of the near-channel environment, creates sinuosity, results in bar deposition and bank erosion, and creates much of the topography of the geomorphic flood plain. Channels abandoned by avulsions and cutoffs become side channels and wetlands. Channel migration creates suitable substrates and colonization areas for aquatic and near-channel flora and fauna. Specific habitat features include in-channel pools and riffles, channel-flanking gravel patches and bars, young and low flood-plain surfaces, and eroding banks, where down-dropped blocks create local and variable habitat conditions. For the Sprague River and its major tributaries, channel migration likely is a self-perpetuating process; lateral erosion provides sediment that builds bars and inner banks, which in turn steer currents against outer banks, promoting lateral erosion.

Sinuosity in the Sprague River study area results from the competing processes of meander enlargement by lateral channel migration, and channel shortening by avulsions and cutoffs that truncate or bypass meander loops. The decreased sinuosity since 1940 (fig. 60) resulted from avulsions and cutoffs forming at rates faster than compensating channel migration, perhaps as a consequence of channel confinement by levees, dikes, and other flood-plain disturbances. Migration rates also have slowed historically (fig. 60), perhaps owing to levee confinement and local bank protection. Recent restoration projects have aimed to restore sinuosity by plugging cutoffs and avulsion channels, and by placing channels back in former meander loops, locally buttressed by various forms of armoring (fig. 23). Instead of attempting to reverse specific cutoffs, however, a more sustainable long-term process-based approach would be to allow sinuosity to increase at broad scales by (1) allowing lateral channel migration in all practical locations; and (2) limiting disturbances promoting avulsions and cutoffs, such as confinement, ditches, and trails. Under such natural equilibrium conditions, cutoffs and avulsions will persist, forming side channels and flood-plain wetlands and thereby increasing habitat diversity, but continued lateral channel migration will maintain sinuosity.

Overbank flooding also is an important process in the Sprague River study area, and is a key component of hydrologic connectivity within the fluvial system (Kondolf and others, 2006). Overbank flooding deposits suspended sediment, augments flood-plain soils, incrementally builds flood-plain surfaces, and promotes lateral exchanges of nutrients, flora, and fauna (Jenkins and Boulton, 2003). Hydraulic consequences include attenuation of flood peaks and lowering of in-channel flow velocities during floods (possibly limiting channel widening and incision). Overbank flow is required for chutes and avulsions, the primary mechanisms by which meanders are cut off and abandoned, leading to side- and off-channel aquatic habitats.

For most of its length, the Sprague River has retained some lateral and longitudinal connectivity. Dams and diversions have been removed from the main-stem Sprague River, leaving only a few such structures in the South Fork and North Fork valley segments. Overbank flooding is still common, as evidenced by the extensive flood-plain inundation during the 2006 high flows, but has been limited in some reaches by levees, dikes, and railroad grades, and in the South Fork valley segment by channel incision. Because of 
the general absence of significant incision for much of the study area, overbank flooding is still an effective process. This condition enhances the potential for restoration of lateral connectivity by passive management approaches, including strategic levee removal and breaching.

Vegetation succession and disturbance processes interact to create the mosaic of riparian and flood-plain vegetation. Vegetation is important in affecting bank stability and geometry, stream shading (and temperature), bank and flood-plain nutrient conditions, in-stream wood loading, and resistance of channel edges and flood-plain surfaces to erosion and channel formation. Although significant trends are evident in cover type in the study area (table 13; figs. 61-66), probably representing changes in types of intensity of disturbance, the basic vegetation types and distributions are similar to the early historical descriptions. Therefore, for most of the study area, the likelihood of attaining riparian vegetation patterns broadly similar to historical conditions is high if the rates and types of disturbance processes revert to more natural conditions, particularly for the more dynamic near-channel environments. The greater proportion of increasing seral stages in the 1968-2000 period compared to the 1940-1968 period (fig. 64) indicates that vegetation can respond at decadal time scales to changes in human disturbance factors. Less evident is whether active vegetation management strategies such as planting are effective in restoring vegetation conditions. Such efforts are particularly challenging in dynamic near-channel environments, where channel migration, flooding, predation, erosion, and deposition can adversely affect planted vegetation, although low migration rates in some reaches may enhance survival. Many recent restoration projects have involved efforts to establish shrubs and trees, but these have been mostly unsuccessful, possibly because of high water tables (Rasmussen, 2011). As for other key flood-plain and channel processes, the main controlling factors such as sediment transport, channel migration, and regular flood-plain inundation still are present for most of the Sprague River study area. Therefore, intense manipulation or active vegetation management may not be necessary to achieve ecologically based vegetation objectives. An uncertain factor, however, is the presence of reed canarygrass, now extensive in several valley segments in the basin. This nonnative species likely will affect restoration efforts by decreasing potential for shrub germination and displacing native herbaceous species, particularly in areas of reduced grazing intensity.

For most of the study area, the processes identified as important for creating and maintaining ecologically beneficial channel and flood-plain conditions still function, although some at altered levels. Therefore, substantial flood-plain and channel manipulation is not required to meet most ecologically based objectives at the broad scales of the geomorphic flood plain and valley segments. Removal of levees and dikes, which locally have confined the channel, might be a widespread active management approach to enhance lateral connectivity and reduce incision potential.
For the South Fork valley segment, however, the key processes and conditions have been altered substantially by diversions, channelization, incision, levee construction, and vegetation manipulation and removal. Therefore, reversing the geomorphic and ecologic changes of the last 100 years is unlikely without substantial manipulation of the channel and flood plain. Even with alterations so that channel migration, overbank flooding, and vegetation secession can proceed, the naturally slow rates of these processes for the Sprague River likely will require decades or centuries for reestablishment of the conditions of the early 1900s in the South Fork valley segment: wet meadows interspersed with luxuriantly vegetated riparian corridors.

\section{Restoration Objectives}

The results of this study provide a means for establishing measurable broadscale objectives for important geomorphic and ecologic processes. This perspective is based on the premise that maintaining and enhancing the key process regimes will broadly enhance ecological conditions in the Sprague River Basin. Therefore, restoration objectives follow from the key process regimes identified here. This approach contrasts with objectives focused on site-specific channel and flood-plain conditions, although this might be appropriate for key habitats at special locations.

One objective could be to maintain, allow, or restore natural channel migration processes, including cutoffs and avulsions, which can be measured in terms of sinuosity, slope, width, migration rates, and bar area. Sinuosity integrates many of these factors, but channel migration rates are an index of channel dynamics, which also underlie many important channel and flood-plain attributes.

A second objective would focus on maintaining and enhancing frequency and extent of overbank flooding and lateral connectivity. In unincised and unconstrained valley segments, a logical objective would be to maintain the present frequency and extent of flooding. Where the channel is incised, an increase in the frequency and extent of flooding would indicate a tendency toward more natural conditions. In these areas, locally increasing channel and flood-plain altitudes indicate channel and flood-plain aggradation, consistent with overbank flooding and exchange of sediment and nutrients between the channel and flood plain. Similarly, a decreasing vertical difference between channel and flood-plain altitude indicates more frequent inundation for a given flood regime. In sections where flooding has been limited by structures such as levees or railroad grades, decreasing the extent of the geomorphic flood plain separated from channel and flood-plain processes by levees, dikes, and other structures would lead to more natural conditions and increase the extent of flooding. Along these lines, dike and levee removal or breaching is one of the very few restoration activities requiring active flood-plain manipulation. 
Broadscale vegetation objectives derived from this study could emphasize the distribution and extent of specific cover types, transitions among cover types, or more general successional or disturbance trends. Because historical and present vegetation conditions vary spatially, such objectives likely could be most usefully established if designed for individual valley segments and separately for near-channel and flood-plain areas. These smaller areas also would likely be the best candidates for objectives pertaining to individual species, as described more fully by Rasmussen (2011).

Whereas all of these types of objectives are relevant to important channel and flood-plain processes and conditions in the Sprague River study area, they may not directly signal trends in the overall regional objectives of restoring endangered fish species and improving water quality (Boyd and others, 2002; National Research Council, 2004; National Resource Conservation Service, 2009). Nevertheless, trends in these indicators almost certainly will relate to overall ecologic integrity in the basin, although such attributes may be difficult to characterize quantitatively.

\section{Monitoring Approaches}

Quantification of these objectives and their attainment could derive from the types of analyses described here that provide information on decadal-scale trends. Repeat mapping of plan-view channel morphology, channel migration rates, and vegetation conditions from new aerial photographs, using the protocols of this study, would allow for direct comparison and measurements of key features used to measure the success of restoration objectives or to document other changes following future disturbances, such as large floods (fig. 60).

New and repeated lidar acquisitions also would facilitate efficient broadscale monitoring, especially if the coverage and quality meet that of the 2004 lidar (Watershed Sciences, Inc., 2005). Topographic analyses of channel and flood-plain surfaces, when compared with previous lidar altitude data, would allow for monitoring channel and flood-plain aggradation and erosion, thereby effectively tracking connectivity between the channel and flood plain. Additionally, by enabling detection of changes in bar and flood-plain sediment volumes, valley-segment and basin-scale sediment budgets could be determined if coupled with long-term sediment measurement programs (for example, Gran and others, 2009). Techniques also are being developed for quantitative characterization of vegetation types and density from lidar altitude data (Forzieri and others, 2010; Pflugmacher and others, 2011), which could enable more quantitative measurement of vegetation trends.

Consistent with all aspects of this study, these types of monitoring approaches are most applicable to broad temporal and spatial scales. Such broadscale monitoring is not likely to discern immediate effects of site-specific restoration activities, but should be able to document trends resulting from the cumulative effects of activities at the scale of valley segments or the entire study area. Similarly, because geomorphic processes are slow in the Sprague River Basin, such monitoring would be conducted most efficiently at decadal time scales, thereby allowing detection of trends and conditions as they respond to flood-plain management actions in reaction to a range of hydrologic and geomorphic events over several years. Additionally, monitoring of the effects of significant flows, such as the monitoring conducted in this analysis of the 2006 high flows, would enable continued assessment of the efficacy of key channel and flood-plain processes during geomorphically effective events.

\section{Summary and Significant Findings}

The Sprague River Basin encompasses 4,167 square kilometers of south-central Oregon and is a primary tributary (via the lower Williamson River) of Upper Klamath Lake. The main-stem Sprague River, as well as the lower reaches of the North Fork Sprague River, South Fork Sprague River, and the Sycan River, meander through broad alluvial valleys historically supporting agriculture and livestock grazing. National and regional interest in restoring Klamath Basin ecosystem conditions and processes has motivated several restoration strategies and projects in the Sprague River Basin to improve aquatic, riparian, and upland habitat conditions. This study - jointly conducted by the U.S. Geological Survey and University of Oregon, and in cooperation with the U.S. Fish and Wildlife Service Klamath Basin Ecosystem Restoration Office and the Hatfield Restoration Programprovides basic information on channel and flood-plain processes and historical trends to help management and regulatory agencies evaluate restoration proposals and to guide effective restoration and monitoring strategies for the Sprague River and its primary tributaries.

The study area covered the lower, alluvial segments of the Sprague River system, including the lower parts of the Sycan River, North Fork Sprague River, South Fork Sprague River, and the entire main-stem Sprague River between the confluence of the North and South Forks and its confluence with the Williamson River at Chiloquin, Oregon. The study used many methods, including mapping and stratigraphic analysis of flood-plain deposits and flanking features; evaluation of historical records and observations; systematic mapping and analysis of flood-plain and channel characteristics (including morphologic and vegetation conditions) from historical surveys, maps, and aerial photographs; and a 2006 survey of depositional features left by early 2006 high flows.

Analyses focused primarily on the channel and flood plain within an area defined as the "geomorphic flood plain." The geomorphic flood plain, covering 78 square kilometers, is the low-lying and relatively flat area flanking the main channels and affected by main-stem fluvial processes of erosion, deposition, channel migration, and flood inundation 
during the Holocene epoch. The geomorphic flood plain was subdivided into 13 valley segments of distinct fluvial and biologic environments on the basis of valley form and major tributary junctions: nine segments that encompass the 136.1 kilometers of main-stem Sprague River, two segments for the lower Sycan River, and one segment for each part of the South Fork Sprague and North Fork Sprague Rivers within the study area.

Segment characteristics range from low-gradient reaches with expansive flood plains to steep and narrow canyons. The wide flood-plain valley segments are broadly similar; most segments contain a sinuous, low-gradient channel that migrates slowly across the valley bottom. The narrow valley segments include the steep, boulder-and-cobble-bed reaches at downstream and upstream ends of the study area as well as other confined valley segments that have similar gradients and substrates as adjacent unconfined valley segments, but much lower sinuosities. Although the geologic setting of the expansive South Fork valley segment resulted in historical conditions of sinuous and poorly defined channels and wet meadows, flanking levees now narrowly confine the channelized South Fork Sprague River for much of its length.

The fine-grained extrusive volcanic rocks and lacustrine sediment that constitute most of the Sprague River Basin do not produce much sand and gravel bed material. In the absence of substantial bed material prior to the Mazama eruption of 7,700 cal yr BP, the main rivers of the study area apparently were flanked by wetlands and low flood plains, and migration rates probably were low. The eruption, however, covered much of the northern basin with sand- and granule-size pumice clasts, transforming the fluvial system by increasing bed-material transport and promoting bar formation and channel migration, particularly for the Sycan and North Fork Sprague Rivers, and the Sprague River downstream of the Sycan River confluence. The South Fork Sprague River, which had much less Mazama pumice deposited in its watershed, remained a wet-meadow fluvial system until historical channelization and diking.

Despite the pumiceous sand input and the general low gradients of the main channels within the study area, the present overall bed-material sediment regime is supply limited, meaning the transport capacity exceeds the supply of bed material. This is evident by the discontinuous alluvial cover of the channel bottom, the sparse bars in and flanking the channel, and the overall slow channel migration rates compared to many western North American rivers.

Although channel migration rates are low, lateral channel movement is an important process for maintaining channel and flood-plain materials, form, and function. Lateral migration forms and expands meanders, which increases sinuosity. Countering meander enlargement are avulsions and meander cutoffs, including chute and neck cutoffs, which decrease sinuosity. The decrease in sinuosity since 1940 for nearly all the unconfined reaches resulted partly from decreased migration rates, but mostly from several cutoffs and avulsions formed mainly between 1940 and 1975 . The greater frequency of avulsions and meander cutoffs possibly resulted from (1) flood-plain confinement by levees, dikes, roads, and railroads leading to deeper and faster overbank flow, thereby promoting erosion of new flood-plain channels; and (2) flood-plain disturbances such as trails, ditches, and vegetation manipulation or eradication that locally concentrated overbank flow and decreased surface resistance to channel erosion.

The Sprague River channel generally is not incised to the extent that floods fail to inundate the flood plain. The floods of 2006 left overbank deposits on flood-plain surfaces along the entirety of the main-stem Sprague, lower Sycan, and lower North Fork Sprague Rivers, consistent with the stratigraphic evidence of substantial flood-plain deposition and accretion during the last several hundred years. By contrast, as much as 1.6 meters of historical incision is evident in the upstream part of the study area, chiefly in the South Fork valley segment, but possibly extending several kilometers downstream of the confluence of the North Fork Sprague River with the South Fork Sprague River.

A general absence of channel incision for much of the study area is consistent with little evidence of channel widening. Neither analyses using General Land Office surveys nor those of historical aerial photographs indicate overall widening or narrowing trends in channel width, although individual valley segments have had channels narrow or widen.

The Sycan River is unique because of the great influence of the Mazama eruption on its catchment. The Sycan flood, shortly after the eruption, formed a broad deposit of loose and coarse pumiceous sand, now incised by the channel and younger flood plains. Episodes of watershed-scale enhanced sediment supply after the flood resulted in construction of sandy flood plains flanking the channel, which continue to be susceptible to lateral erosion. Because of the higher bed-material sediment supply, the Lower Sycan valley segment has abundant bars, wide channels, and high migration rates relative to other valley segments.

The South Fork Sprague River was affected little by the Mazama eruption; consequently, the historical condition of its fluvial systems probably was much different from that of the Sycan River and, to a lesser extent, the North Fork Sprague River. At the time of the General Land Office surveys in the 1860s and for thousands of years prior, the South Fork Sprague River probably was a poorly defined, stable (and locally multithreaded) channel and wet-meadow complex fringed by willows, seasonally flooding and slowly aggrading the expansive valley bottom by depositing sediment. Beaver likely contributed to wet-meadow flood plain and channel conditions.

Human actions, however, locally have affected Sprague River channel and flood-plain conditions since the first European settlement in the 1860s. Most evident are the 
contemporaneous and persistent effects of channelization and flood-plain confinement by levees, roads, and the former Oregon, California, and Eastern Railroad alignment, dating mainly from the 1920s through the 1970s. Channelization before 1940 transformed the South Fork Sprague River into an incised channel of low sinuosity. Less evident are the effects of levees, but flood-plain confinement probably has increased the frequency of avulsions and cutoffs, resulting in reduced sinuosity and overall greater channel slopes since 1940. Riparian grazing and channel and bank trampling by cattle locally have affected bank and channel conditions, as have local accumulations of dumped rock at fords and former bridge crossings. Channel remeandering, mostly since 2000, locally has resulted in the filling of chute cutoffs, avulsions, and the placement of the primary channel back in its historical positions.

The South Fork Sprague River, compared to other valley segments in the study area, has been the most clearly transformed since first historical observations. The present channel is incised, straightened, and separated from the flood plain by levees for much of its alluvial corridor. Significant parts of the flood plain have been drained and leveled. Many in-channel structures currently divert flow into irrigation channel networks. This valley segment also appears to be a major source of suspended sediment to the Sprague River fluvial system.

Despite these broadscale and local effects of human disturbances, many of the fundamental physical processes that have shaped the Sprague River fluvial systems over the last several thousand years still function. Most importantly, upstream impoundments do not significantly interrupt flow or sediment. Consequently, overall bed-material transport conditions are similar to historical conditions, including sediment supply and water flow. Lateral connectivity is mostly also preserved because of the absence of system-wide channel incision, which can limit restoration opportunities. Areas of the fluvial system that have been incised, particularly the South Fork valley segment, are in the upstream part of the study area, limiting the likelihood that geomorphic effects (aside from changes in flow and sediment transport) will migrate to other parts of the study area. These factors suggest that restoration of many of the native physical conditions and processes is possible for much of the Sprague River study area without substantial physical manipulation of current conditions.

General spatial patterns of vegetation in the Sprague River flood plain are influenced by broadscale basin characteristics. Tall woody species prefer narrow, confined, and shaded flood plains. Wide flood plains mostly are covered with herbaceous plants, but past and present channel areas locally are flanked by short woody vegetation. These predominant attributes have persisted since the first historical observations in the 1800 s, chiefly because the areas within the study area have remained mostly pastoral, without substantial urbanization, timber harvest (within the flood plain) or basin-scale changes in flow and sediment regimes. At finer scales, however, near-channel areas are more dynamic than the flood plain as a whole (representing the important roles of fluvial disturbance and succession in creating riparian vegetation communities), perhaps exacerbated by predation and concentrated grazing.

Some individual vegetation cover types, however, show clear trends. The most evident is the loss of short woody vegetation: only one-half the near-channel area covered by short woody vegetation in 1940 was covered similarly in 2000. The loss of short woody vegetation to less-complex, early seral (successional) stages was the chief change among many indicating vegetation disturbance and loss of structural complexity, particularly before 1968. Since 1968, changes have been smaller and more evenly distributed between increasing and decreasing seral stages.

Vegetation changes have resulted from a combination of geomorphic processes and trends, vegetation succession, direct vegetation manipulation, and broadscale land use. Transitions among the bare and water cover types chiefly are the result of decreased sinuosity and large floods. Woody vegetation removal in the 1950s and 1960s and continuing grazing and trampling by livestock probably are the main reasons for the decrease in short woody vegetation from the locally dense riparian corridors of willows and other riparian shrubs noted in the early 20th century. Since 1968, vegetation succession locally has increased seral stage and habitat complexity, partly compensating for earlier losses.

The findings regarding physical processes, historical conditions, and vegetation patterns and changes have implications for restoration and monitoring of the Sprague River Basin. Most importantly, many physical processes and conditions responsible for channel and flood-plain formation still function. This contrasts with many western rivers, in which dams and diversions have substantially affected sediment and water fluxes, and where channel incision has limited interaction between channels and flood plains. Because overall basin conditions are not markedly altered in the Sprague River Basin, historical conditions provide a plausible reference frame for restoration objectives.

For the broad area of the Sprague River study area in which flood flows regularly inundate the flood plain, natural processes may be sufficient under proper conditions to reverse historical trends of decreasing sinuosity and loss of short woody vegetation cover. However, for the alluvial section of the South Fork Sprague River, historical and ongoing channel incision and flood-plain erosion will inhibit reversal of historical trends and likely will continue to be a source of suspended sediment load to the river system. For this reach, incision likely will continue as long as the channel is fully constrained by levees and dikes and until knickzones progress to locations where channel substrate resists continued downcutting. Although changes may slow in the South Fork 
Sprague River valley segment under present conditions, historical trends are not likely to reverse until it attains a more natural channel and flood-plain geometry and the channel aggrades to the extent that overbank flow becomes common.

For most of the Sprague River flood plain, the greatest likelihood of restoration to pre-development conditions would result from a strategy emphasizing natural processes for the entire geomorphic flood plain. A less conservative strategy could reverse historical changes by focusing on a narrower region about the channel, where processes are most dynamic and the coupling between channel and flood plain is strongest. Such a strategy, however, has some risk because avulsions and cutoffs, which create ecologically important flood-plain features, extend to areas beyond the near-channel environment.

An important aspect of the Sprague River study area relative to restoration is that geomorphic processes are slow. The low slopes, low bed-material supply and transport rates, and low stream powers all result in naturally slow rates of channel and flood-plain evolution. In particular, rates of channel migration, meander enlargement, lateral and vertical flood-plain building, and short woody vegetation recovery are likely to require decades or longer under passive management scenarios. Therefore, restoration objectives dependent on natural processes may take more time to achieve in the Sprague River Basin than in more energetic and sediment-rich fluvial systems more typical in western North America.

The findings from this study indicate that the following activities can facilitate natural geomorphic and vegetation processes important to ecological conditions in the Sprague River Basin:

1. Maintain or restore natural channel migration processes, including channel avulsions and cutoffs. Sinuosity integrates many of these factors, but channel migration rates are an index of channel dynamics, which also underlie many important channel and floodplain attributes.

2. Maintain and enhance the frequency and extent of overbank flooding and lateral connectivity between channels and flood plains. In unincised and unconstrained valley segments, a logical objective would be to maintain the present frequency and extent of flooding. In sections where flooding has been limited by incision or structures such as levees or railroad grades, decreasing the extent of the geomorphic flood plain separated from channel and flood-plain processes by levees, dikes, and other structures would increase the frequency and extent of flooding and enhance flood-plain deposition.

3. Promote vegetation succession and disturbance processes conducive to reversing historical losses of short woody vegetation cover types. Additional vegetation objectives could focus on distribution and extent of specific cover types, transitions among cover types, or more general successional or disturbance trends. Because historical and present vegetation conditions vary spatially, such objectives likely could be established most effectively if they are designed for individual valley segments and separately for near-channel and flood-plain areas.

Monitoring the outcomes of these activities could rely on some of the methods used in this study. Repeat mapping of channel and flood-plain conditions from new aerial photographs would allow for direct comparison and measurements of plan-view channel morphology, channel migration rates, and vegetation conditions. Additionally, monitoring of the effects of significant flows, such as the analysis of the 2006 high flows, would enable continued assessment of key channel and flood-plain processes during geomorphically effective events. Such broadscale monitoring is not likely to discern immediate effects of site-specific restoration activities, but should be able to document trends resulting from the cumulative effects of activities at the scale of valley segments or the entire study area.

\section{Acknowledgments}

Sue Mattenberger of the U.S. Fish and Wildlife Service and Larry Dunsmoor of the Klamath Tribes facilitated this project. Graham Mathews and Associates shared information on their ongoing channel geomorphology and sediment transport analyses and assisted in acquisition of the 1940 aerial photographs. Terry and Jessi Shields (and their family) provided significant logistical support for our field work. Access to field sites was provided graciously by many property owners, including Scott Phillips; Rod Kornnelson; John and Lil Kronenberger; Dean and Chloe Walker; Becky and Taylor Hyde; Ken and Dianne Busher; Jim Hadyn-Meyer; Jim Flinn; Greg Bulkley; Bob and Roberta Valladao; Ken Willard; Andrea, Clifford, and Mary Rabe; John and Barbara Fugatt; Mike Lelmorini; Dan and Kathy Ridgeway; Greg Harris; and Jim Wayne. We benefited from discussions and assistance from Larry Dunsmoor, Sue Mattenberger, Greg Harris, Michael Hughes, Faith Fitzpatrick, Paul Pedone, Marshall Gannett, Alex Bourdeau, and Dave Sherrod. Assistance with analysis and report preparation was provided by Keith Jackson, Tana Haluska, Joseph Mangano, and John Williams. Chris Carlson, Matt Derrick, Benn Hackett, John Lind, Jessica Phelps, and Jason Stuckey assisted in the field.

\section{References Cited}

Amlin, N. and Rood, S., 2002, Comparative tolerances of riparian willows and cottonwoods to water-table decline: Wetlands, v. 22, no. 2, p. 338-346.

Armour, C.L., Duff, D.A., and Elmore, W., 1991, The effects of livestock grazing on riparian and stream ecosystems: Fisheries, v. 16, p. 7-11. 
Bacon, C.R., 1983, Eruptive history of Mount Mazama and Crater Lake caldera, Cascade Range, U.S.A: Journal of Volcanology and Geothermal Research, v. 18, nos. 1-4, p. $57-115$.

Bacon, C.R., and Lanphere, M.A., 1990, The geologic setting of Crater Lake, Oregon, in Wood, C.A., and Kienle, J., eds., Volcanoes of North America-United States and Canada: New York, Cambridge University Press, p. 193-195.

Bacon, C.R., and Lanphere, M.A., 2006, Eruptive history and geochronology of Mount Mazama and the Crater Lake region, Oregon: Geological Society of America Bulletin, v. 118, nos. 11-12, p. 1331-1359., http://pubs.er.usgs.gov/ publication/70028576.

Bailey, V., 1936, The mammals and life zones of Oregon: North American Fauna, no. 55, 416 p.

Beechie, T., Pess, G., Roni, P., and Giannico, G., 2008, Setting river restoration priorities - A review of approaches and a general protocol for identifying and prioritizing actions: North American Journal of Fisheries Management, v. 28, no. 3, p. 891-905, doi:10.1577/M06-174.1.

Bendix, J., 1997, Flood disturbance and the distribution of riparian species diversity: Geographical Review, v. 87, no. 4 , p. $468-483$.

Bernhardt, E.S., and Palmer, M.A., 2011, River restorationthe fuzzy logic of repairing reaches to reverse catchment scale degradation: Ecological Applications, v. 21, no. 6, p. 1926-1931.

Beschta, R.L., Pyles, M.R., Skaugset, A.E., and Surfleet, C.G., 2000, Peakflow responses to forest practices in the western cascades of Oregon, USA: Journal of Hydrology, v. 233, p. 102-120.

Biondini, M., and Kandus, P., 2006, Transition matrix analysis of land-cover change in the accretion area of the lower delta of the Paraná River (Argentina) reveals two succession pathways: Wetlands, v. 26, no. 4, p. 981-991.

Bornette, G., and Amoros, C., 1996, Disturbance regimes and vegetation dynamics - Role of floods in riverine wetlands: Journal of Vegetation Science, v. 7, no. 5, p. 615-622.

Bornette, G., Tabacchi, E., Hupp, C., Puijalon, S., and Rostan, J.C., 2008, A model of plant strategies in fluvial hydrosystems: Freshwater Biology, v. 53, no. 8, p. 1692-1705.

Boyd, M., Kirk, S., Wiltsey, M., and Kasper, B., 2002, Upper Klamath Lake drainage total maximum daily load (TMDL) and water quality management plan (WQMP): Portland, Oregon Department of Environmental Quality, 204 p., accessed November 18, 2013, at http://www.deq.state.or.us/ $\mathrm{wq} / \mathrm{tmdls} /$ docs/klamathbasin/ukldrainage/tmdlwqmp.pdf.
Bronk Ramsey, C., 2001, Development of the radiocarbon calibration program $\mathrm{OxCal}$ : Radiocarbon, v. 43 , no. $2 \mathrm{~A}$, p. 355-363.

Brooks, G.R., 2003, Holocene lateral channel migration and incision of the Red River, Manitoba, Canada: Geomorphology, v. 54, nos. 3-4, p. 197-215.

Bureau of Land Management, 2011, Land status and cadastral records viewer, Willamette meridian-Oregon and Washington States: U.S. Department of the Interior, Bureau of Land Management Web site, accessed November 18, 2013, at http://www.blm.gov/or/landrecords/survey/ySrvy1. php.

Butler, V.L., Miller, J.A., Yang, D.Y., Speller, C.F., and Misarti, N., 2010, The use of archaeological fish remains to establish pre-development salmonid biogeography in the Upper Klamath Basin: Prepared by Portland State University, Department of Anthropology, Portland, Oregon, for National Marine Fisheries Service, 101 p.

Cahoon, J.S., 1985, Soil survey of Klamath County, Oregon-Southern part: U.S.Department of Agriculture Soil Conservation Service and Oregon State University Agricultural Experiment Station, 106 map sheets, 269 p.

Castelli, R., Chambers, J., and Tausch, R., 2000, Soil-plant relations along a soil-water gradient in Great Basin riparian meadows: Wetlands, v. 20, no. 2, p. 251-266.

Chapin, D.M., Beschta, R.L., and Wen Shen, H., 2002, Relationships between flood frequencies and riparian plant communities in the Upper Klamath Basin, Oregon: Journal of the American Water Resources Association, v. 38, no. 3, p. 603-617.

Cluer, B., and Thorne, C., 2013, A stream evolution model integrating habitat and ecosystem benefits: River Research and Applications, 20p., doi:10.1002/rra/2631.

Coffman, D.K., Malstaff, Greg, and Heitmuller, F.T., 2011, Characterization of geomorphic units in the alluvial valleys and channels of Gulf Coastal Plain rivers in Texas, with examples from the Brazos, Sabine, and Trinity Rivers, 2010: U.S. Geological Survey Scientific Investigations Report 2011-5067, 31 p. http://pubs.usgs.gov/ $\operatorname{sir} / 2011 / 5067 /$.

Collins, B.D., Montgomery, D.R., Fetherston, K.L., and Abbe, T.B., 2012, The floodplain large-wood cycle hypothesis-A mechanism for the physical and biotic structuring of temperate forested alluvial valleys in the North Pacific coastal ecoregion: Geomorphology, v. 139-140, p. 460-470.

Collins, B.D., Montgomery, D.R., and Sheikh, A.J., 2003, Reconstructing the historical riverine landscape of the Puget Lowland, in Montgomery, D.R., Bolton, S., Booth, D.B., and Wall, L., eds., Restoration of Puget Sound Rivers: Seattle, University of Washington Press, p. 79-128. 
Conaway, J.S., 2000, Hydrogeology and Paleohydrology of the Williamson River Basin, Klamath County, Oregon: Portland, Oregon, Portland State University, M.S. thesis, $116 \mathrm{p}$.

Connelly, M., and Lyons, L., 2007, Upper Sprague watershed assessment: Klamath Falls, Oregon, Klamath Basin Ecosystem Foundation, 266 p.

Cooke, R.U., and Reeves, R.W., 1976, Arroyos and environmental change in the American Southwest: London, Oxford University Press, 213 p.

Cordes, L.D., Hughes, F.M.R., and Getty, M., 1997, Factors affecting the regeneration and distribution of riparian woodlands along a northern prairie river-The Red Deer River, Alberta, Canada: Journal of Biogeography, v. 24, p. 675-695.

Cowardin, L.M., Carter, V., Golet, F.C., and Laroe, E.T., 1979, Classification of wetlands and deepwater habitats of the United States: U.S. Fish and Wildlife Service, FWS/OBS79/31, p. 103.

Cressman, L.S., Haag, W.G., and Laughlin, W.S., 1956, Klamath Prehistory - the prehistory of the culture of the Klamath Lake area, Oregon: Transactions of the American Philosophical Society, v. 46, no. 4, p. 375-513.

Cummings, M.L., and Conaway, J.S., 2009, Landscape and hydrologic response in the Williamson River basin following the Holocene eruption of Mount Mazama, Cascade volcanic arc, in O'Connor, J.E., Dorsey, R.J., and Madin, I., eds., Volcanoes to vineyards - Geologic field trips through the dynamic landscape of the Pacific Northwest: Boulder, Colorado, Geological Society of America, p. 271-294.

Dietrich, W.E., Day, G., and Parker, G., 1999, The Fly River, Papua New Guinea-inferences about river dynamics, floodplain sedimentation and fate of sediment, in Miller, A.J., and Gupta, A., eds., Varieties of fluvial form: New York, Wiley, p. 345-376.

Dietrich, W.E., Smith, J.D., and Dunne, T., 1979, Flow and sediment transport in a sand bedded meander: The Journal of Geology, v. 87, no. 3, p. 305-315.

Draut, A.E., Logan, J.B., and Mastin, M.C., 2011, Channel evolution on the dammed Elwha River, Washington, USA: Geomorphology, v. 127, nos. 1-2, p. 71-87.

Ellsworth, C.M., Tyler, T.J., VanderKooi, S.P., and Shively, R.S., 2007, Riverine movements of adult Lost River, shortnose, and Klamath largescale suckers in the Williamson and Sprague Rivers, Oregon-Annual Report 2006: Bureau of Reclamation Contract no. 01AA200026, p. 49.
Fenneman, N.M., 1931, Physiography of the western United States: New York, McGraw-Hill, 534 p.

Florsheim, J.L., Mount, J.F., and Chin, A., 2008, Bank erosion as a desirable attribute of rivers: BioScience, v. 58 , no. 6 , p. 519-529.

Forzieri, G., Moser, G., Vivoni, E.R., Castelli, F., and Canovaro, F., 2010, Riparian vegetation mapping for hydraulic roughness estimation using very high resolution remote sensing data fusion: Journal of Hydraulic Engineering, v. 136, no. 11, p. 855-867.

Gannett, M.W., Lite, K.E.J., La Marche, J.L., Fisher, B.J., and Polette, D.J., 2007, Ground-water hydrology of the upper Klamath Basin, Oregon and California: U.S. Geological Survey Scientific Investigations Report 2007-5050, 84 p., http://pubs.usgs.gov/sir/2007/5050/.

Gatschet, A.S., 1890, The Klamath Indians of southwestern Oregon-Ethnographic sketch of the people: U.S. Geographical and Geological Survey of the Rocky Mountain Region, v. 2, 635 p.

Gautier, E., Brunstein, D., Vauchel, P., Roulet, M., Fuertes, O., Guyot, J.L., Darozzes, J., and Bourrel, L., 2007, Temporal relations between meander deformation, water discharge and sediment fluxes in the floodplain of the Rio Beni (Bolivian Amazonia): Earth Surface Processes and Landforms, v. 32, no. 2, p. 230-248.

Giardino, J.R., and Lee, A.A., 2011, Rates of channel migration on the Brazos River, Final report: Prepared by Texas A\&M University, Department of Geology and Geophysics, College Station, Texas, for the Texas Water Development Board, 128 p.

Gilvear, D.J., Winterbottom, S., and Sichingabula, H., 2000, Character of channel planform change and meander development-Luangwa River, Zambia: Earth Surface Processes and Landforms, v. 25, p. 421-436., doi: 10.1002/(SICI)1096-9837(200004)25:4<421::AIDESP65>3.0.CO;2-Q.

Graham Matthews and Associates, 2007, Sprague River watershed-Sediment transport and a preliminary sediment budget, WY 2004-2006: prepared for the Klamath Tribes, Chiloquin, Oregon, 19 p.

Gran, K.B., Belmont, P., Day, S.S., Jennings, C., Johnson, A., Perg, L., and Wilcock, P.R., 2009, Geomorphic evolution of the Le Sueur River, Minnesota, USA, and implications for current sediment loading, in James, L.A., Rathburn, S.L., and Whittecar, G.R., eds., Management and restoration of fluvial systems with broad historical changes and human impacts: Geological Society of America Special Paper 451, p. 119-130. 
Grant, G.E., Lewis, S.L., Swanson, F.J., Cissel, J.H., and McDonnell, J.J., 2008, Effects of forest practices on peak flows and consequent channel response-A state-of-science report for western Oregon and Washington: U.S. Forest Service General Technical Report PNW-GTR-760, 76 p.

Green, D.M., and Kauffman, J.B., 1995, Succession and livestock grazing in a northeastern Oregon riparian ecosystem: Journal of Range Management, v. 48, no. 4, p. 307-313.

Gregory, S.V., and Bisson, P.A., 1997, Degradation and loss of anadromous salmonid habitat in the Pacific Northwest, in Stouder, D.J., Bisson, P.A., and Naiman, R.J., eds., Pacific salmon and their ecosystems: New York, Chapman and Hall, p. 277-314.

Gregory, S.V., Boyer, K.L., and Gurnell, A.M., eds., 2003, The ecology and management of wood in world rivers: Bethseda, Maryland, Proceedings of the American Fisheries Society, Symposium 37, Corvallis, Oregon, October 23-27, 2000, 444 p.

Gurnell, A., Thompson, K., Goodson, J., and Moggridge, H., 2008, Propagule deposition along river margins - Linking hydrology and ecology: Journal of Ecology, v. 96, no. 3, p. $553-565$.

Hallett, D.J., Hills, L.V., and Clague, J.J., 1997, New accelerator mass spectrometry radiocarbon ages for the Mazama tephra layer from Kootenay National Park, British Columbia, Canada: Canadian Journal of Earth Sciences, v. 34, no. 9, p. 1202-1209.

Hamilton, J.B., Curtis, G.L., Snedaker, S.M., and White, D.K., 2005, Distribution of anadromous fishes in the upper Klamath River watershed prior to hydropower dams-A synthesis of the historical evidence: Fisheries, v. 30, no. 4 , p. $10-20$.

Hammer, T.R., 1972, Stream channel enlargement due to urbanization: Water Resources Research, v. 8, no. 6, p. $1530-1540$.

Helfrich, Devere, 1974, Klamath Echoes-Sprague River Valley and Bly: Klamath Falls, Oregon, Klamath County Historical Society, $97 \mathrm{p}$.

Henshaw, F.F., 1912, Preliminary report on water resources of Klamath Indian Reservation, Oregon: U.S. Geological Survey report, 58 p., (copy in files of Oregon Water Science Center, Portland, Oregon).

Hibbard, K.A., Schimel, D.S., Archer, S., Ojima, D.S., and Parton, W., 2003, Grassland to woodland transitionsIntegrating changes in landscape structure and biogeochemistry: Ecology, v. 81, p. 2686-2703.
Hickin, E.J., 1974, The development of meanders in natural river-channels: American Journal of Science, v. 274, p. 414-442.

Holland, K.A., Leininger, W.C., and Trlica, M.J., 2005, Grazing history affects willow communities in a montane riparian ecosystem: Rangeland Ecology \& Management, v. 58 , no. 2 , p. $148-154$.

Hooke, J.M., 1997, Styles of channel change, chap. 11 , in Thorne, C.R., Hey, R.D., and Newson, M.D., eds., Applied fluvial geomorphology for river engineering and management: Chichester, United Kingdom, Wiley, p. 237-268.

Hooke, J.M., 2003, River meander behaviour and instability - A framework for analysis: Transactions of the Institute of British Geographers, v. 28, no. 2, p. 238-253.

Hughes, M.L., and Leeseberg, C., 2009, Vegetation and geomorphic significance of the riparian greenline in the Sprague River Basin, southern Oregon-Implications for biogeomorphic monitoring of riparian corridors in semi-arid mountain valleys [abs.]: Eos Transactions of the American Geophysical Union, v. 90, no. 52, Fall Meeting Supplement, abs. H52D-06.

Hughes, M.L., Lind, P., McDowell, P.F., and O'Connor, J.E., 2009, Channel-floodplain hydrogeomorphology downstream of an early Holocene dam-outburst flood deposit-Long-term effects of extreme sediment loading in the Sycan and Sprague Rivers, southern Oregon [abs.]: Geological Society of America Abstracts with Programs, v. 41 , no. 7 , p. 574 , abs. $225-6$.

Hughes, M.L., McDowell, P.F., and Marcus, W.A., 2006, Accuracy assessment of georectified aerial photographsImplications for measuring lateral channel movement in a GIS: Geomorphology, v. 74, nos. 1-4, p. 1-16.

Hupp, C.P., and Osterkamp, W.R., 1996, Riparian vegetation and fluvial geomorphic processes: Geomorphology, v. 14, p. $277-295$.

Ives, R.L., 1942, The beaver-meadow complex: Journal of Geomorphology, v. 5, p. 191-203.

Jaquette, C., Wohl, E., and Cooper, D., 2005, Establishing a context for river rehabilitation, North Fork Gunnison River, Colorado: Environmental Management, v. 35, no. 5, p. 593-606.

Jenkins, D.L., and Connolly, T.J., 2007, Archaeological data recovery plan for the Beatty Curve site (35KL95): Oregon Department of Transportation Geo-Environmental Services Unit ODOT Key \#12402, 36 p. 
Jenkins, K.M., and Boulton, A.J., 2003, Connectivity in a dryland river-Short-term aquatic microinvertebrate recruitment following floodplain inundation: Ecology, v. 84, no. 10, p. $2708-2723$.

Jenkins, S.H., and Busher, P.E., 1979, Castor canadensis: Mammalian Species, v. 120, p. 1-8.

Jenks, M.J., 2007, An investigation of riparian land use changes adjacent to the Mulberry River and Big Piney Creek from 1936, 1967, and 2001, Ozark-St. Francis National Forests, Arkansas: Geological Society of America Abstracts with Programs, v. 39, no. 2, p. 29.

Jones, J.A., and Grant, G.E., 1996, Peak flow response to clear-cutting and roads in small and large basins, western Cascades, Oregon: Water Resources Research, v. 32, no. 4, p. 959-974, doi:10.1029/95WR03493.

Karrenberg, S., Edwards, P.J., and Kollmann, J., 2002, The life history of Salicaceae living in the active zone of floodplains: Freshwater Biology, v. 47, no. 4, p. 733-748.

Kauffman, J.B., and Krueger, W.C., 1984, Livestock impacts on riparian ecosystems and streamside management implications-A review: Journal of Range Management, v. 37 , no. 5 , p. $430-438$.

Kent, F.L., 1905, Irrigation in Klamath County, Oregon, in Annual report of irrigation and drainage investigations, 1904: U.S. Department of Agriculture Office of Experiment Stations Bulletin 158, p. 257-266.

Knox, J.C., 1977, Human impacts on Wisconsin stream channels: Annals of the Association of American Geographers, v. 67, no. 3, p. 323-342.

Kondolf, G.M., Boulton, A.J., O’Daniel, S., Poole, G.C., Rahel, F.J., Stanley, E.H., Wohl, E., Bång, A., Carlstrom, J., Cristoni, C., Huber, H., Koljonen, S., Louhi, P., and Nakamura, K., 2006, Process-based ecological river restoration-Visualizing three-dimensional connectivity and dynamic vectors to recover lost linkages: Ecology and Society, v. 11, no. 2, 17 p.

Kondolf, G.M., and Piegay, H., 2003. Tools in fluvial geomorphology-Problem statement and recent practice, in Kondolf, G.M., and Piegay, H., eds., Tools in fluvial geomorpholgy: Chichester, United Kingdom, Wiley, p. 3-22.

Kramer, N., Wohl, E.E., and Harry, D.L., 2012, Using ground penetrating radar to 'unearth' buried beaver dams: Geology, v. 40 , no. 1, p. 43-46.

La Rue, E.C., 1922, Klamath River and its utilization: Report to the Office of the State Engineer, Salem, Oregon, 204 p.
Leiberg, J.B., 1903, Southern part of Cascade Range Forest Reserve, in Langille, H.D., Plummer, F.G., Dodwell, A., Rixon, T.F., and Leiberg, J.B., Forest conditions in the Cascade Range Forest Reserve, Oregon: U.S. Geological Survey Professional Paper 9, p. 229-288, http://pubs. er.usgs.gov/publication/pp9.

Li, S., Pezeshki, S.R., and Shields, F.D., Jr., 2006, Partial flooding enhances aeration in adventitious roots of black willow (Salix nigra) cuttings: Journal of Plant Physiology: v. 163, p. 619-628.

Lind, P., 2009, Holocene floodplain development of the lower Sycan River, Oregon: Eugene, Oregon, University of Oregon M.S. thesis, $218 \mathrm{p}$.

Lobeck, A.K., 1939, Geomorphology: New York, McGrawHill, $731 \mathrm{p}$.

MacWilliams, J.M.L., Tompkins, M.R., Street, R.L., Kondolf, G.M., and Kitanidis, P.K., 2010, Assessment of the effectiveness of a constructed compound channel river restoration project on an incised stream: Journal of Hydraulic Engineering, v. 136, no. 12, p. 1042-1052.

Massong, T.M., and Montgomery, D.R., 2000, Influence of sediment supply, lithology, and wood debris on the distribution of bedrock and alluvial channels: Geological Society of America Bulletin, v. 112, no. 4, p. 591-599.

Micheli, E.R., Kirchner, J.W., and Larsen, E.W., 2004, Quantifying the effect of riparian forest versus agricultural vegetation on river meander migration rates, central Sacramento River, California, USA: River Research and Applications, v. 20, no. 5, p. 537-548.

Minckley, T.A., Whitlock, Cathy, and Bartlein, P.J., 2007, Vegetation, fire, and climate history of the northwestern Great Basin during the last 14,000 years: Quaternary Science Reviews, v. 26, nos. 17-18, p. 2167-2184.

Montgomery, D.R., Collins, B.D., Buffington, J.M., and Abbe, T.B., 2003, Geomorphic effects of wood in rivers, in Gregory, S.V., Boyer, K.L., and Gurnell, A.M., eds., The ecology and management of wood in world rivers: Proceedings of the American Fisheries Society Symposium, 37th, Corvallis, Oregon, October 23-27, 2000, p. 21-47.

Naiman, R.J., Johnston, C.A., and Kelley, J.C., 1988, Alteration of North American streams by beaver: BioScience, v. 38, no. 11, p. 753-762.

Nanson, G.C., and Hickin, E.J., 1986, A statistical analysis of bank erosion and channel migration in western Canada: Geological Society of America Bulletin, v. 97, p. 497-504.

National Research Council, 1992, Restoration of aquatic ecosystems - Science, technology and public policy: Washington, D.C., The National Academies Press, 576 p. 
National Research Council, 1996, Upstream-Salmon and society in the Pacific Northwest: Washington, D.C., The National Academies Press, 472 p.

National Research Council, 2002, Riparian areas-Functions and strategies for management: Washington, D.C., The National Academies Press, 444 p.

National Research Council, 2004, Endangered and threatened fishes in the Klamath River Basin-Causes of decline and strategies for recovery: Washington, D.C., The National Academies Press, 424 p.

Newberry, J.S., 1857, Routes in California and Oregon explored by Lieut. R.S. Williamson, Corps of Topographical Engineers-Geological Report, v. 6, part 2, no. 1, in Abbot, H.L., Reports of explorations and surveys, to ascertain the most practicable and economical route for a railroad from the Mississippi River to the Pacific Ocean: Washington, D.C., A.O.P. Nicholson, 114 p.

NewFields River Basin Services and Kondolf, G.M., 2012, Evaluating stream restoration projects in the Sprague River Basin: Prepared for Klamath Watershed Partnership in conjunction with the Klamath Tribes, U.S. Fish and Wildlife Service, Klamath Basin Rangeland Trust, Sustainable Northwest, and The Nature Conservancy, 222 p., accessed February 22, 2013, at www.klamathpartnership.org/pdf/ SpraguePPA_Final_120912.pdf.

O’Connor, J.E., Curran, J.H., Beebee, R.A., Grant, G.E., and Sarna-Wojcicki, A., 2003a, Quaternary geology and geomorphology of the lower Deschutes River canyon, Oregon, in O'Connor, J.E., and Grant, G.E., eds., A peculiar river-geology, geomorphology, and hydrology of the Deschutes River, Oregon: American Geophysical Union Water Science and Application Series no. 7, p. 73-94.

O’Connor, J.E., Grant, G.E., and Haluska, T.L., 2003b, Overview of geology, hydrology, geomorphology, and sediment budget of the Deschutes River Basin, Oregon, in O’Connor, J.E., and Grant, G.E., eds., A peculiar rivergeology, geomorphology, and hydrology of the Deschutes River, Oregon. American Geophysical Union Water Science and Application Series no. 7, p. 7-30.

O’Connor, J.E., Jones, M.A., and Haluska, T.L., 2003c, Flood plain and channel dynamics of the Quinault and Queets Rivers, Washington, USA: Geomorphology, v. 51, nos. 1-3, p. 31-59.

O’Connor, J.E., Sarna-Wojcicki, A., Wozniak, K.C., Polette, D.J., and Fleck, R.J., 2001, Origin, extent, and thickness of Quaternary geologic units in the Willamette Valley, Oregon: U.S. Geological Survey Professional Paper 1620, 52 p., http://pubs.usgs.gov/pp/1620/.
Oregon Institute of Technology and Shaw Historical Libraries, 2011, Klamath Basin General Land Office (GLO) survey notes transcription: Klamath Waters Digital Library database, accessed November 20, 2013, at http:// klamathwaterlib.oit.edu/GLOSurvey/index.htm.

Palmer, M.A., Bernhardt, E.S., Allan, J.D., Lake, P.S., Alexander, G., Brooks, S., Carr, J., Clayton, S., Dahm, C.N., Follstad Shah, J., Galat, D.L., Loss, S.G., Goodwin, P., Hart, D.D., Hassett, B., Jenkinson, R., Kondolf, G.M., Lave, R., Meyer, J.L., O’Donnell, T.K., Pagano, L., and Sudduth, E., 2005, Standards for ecologically successful river restoration: Journal of Applied Ecology, v. 42, no. 2, p. 208-217.

Personius, S.F., Kelsey, H.M., and Grabau, P.C., 1993, Evidence for regional stream aggradation in the central Oregon Coast Range during the Pleistocene-Holocene transition: Quaternary Research, v. 40, no. 3, p. 297-308.

Petit, C., Scudder, T., and Lambin, E., 2001, Quantifying processes of land-cover change by remote sensingResettlement and rapid land-cover changes in south-eastern Zambia: International Journal of Remote Sensing, v. 22, no. 17 , p. $3435-3456$.

Pflugmacher, D., Cohen, W.B., Ohmann, J.L., and Kennedy, R.E., 2011, Mapping current conditions and modeling the dynamic responses of riparian vegetation and salmonid habitat in Oregon: Prepared by Oregon State University, Corvallis, Oregon, and U.S. Forest Service, Pacific Northwest Research Station, Corvallis, Oregon, Mapping Component OWEB 208-8007-5781, 39 p.

Poff, N., and Ward, J., 1990, Physical habitat template of lotic systems - Recovery in the context of historical pattern of spatiotemporal heterogeneity: Environmental Management, v. 14 , no. 5 , p. 629-645.

Pollen-Bankhead, N., and Simon, A., 2008, Enhanced application of root-reinforcement algorithms for bankstability modeling: Earth Surface Processes and Landforms, v. 34, p. $471-480$.

PRISM Climate Group, 2012, Oregon climate data: Corvallis, Oregon State University, PRISM Climate Group database, accessed November 20, 2013, at http://www.prism. oregonstate.edu.

Prowse, T.D., and Culp, J.M., 2003, Ice breakup-A neglected factor in river ecology: Canadian Journal of Civil Engineering, v. 30, no. 1, p. 128-144.

Rabe, A., and Calonje, C., 2009, Lower Sprague-lower Williamson watershed assessment: Prepared by Rabe Consulting with maps and figures by E\&S Environmental Chemistry, Inc., Corvallis, Oregon, for the Klamath Watershed Partnership, Klamath Falls, Oregon [variously paged]. 
Rasmussen, C.G., 2011, Geomorphology, hydrology and biology of floodplain vegetation in the Sprague basin, Oregon-History and potential for natural recovery: Eugene, University of Oregon Ph.D. dissertation, 105 p.

Reimer, P.J., Baillie, M.G.L., Bard, E., Bayliss, A., Beck, J.W., Blackwell, P.G., Ramsey, C.B., Buck, C.E., Burr, G.S., Edwards, R.L., Friedrich, M., Grootes, P.M., Guilderson, T.P., Hajdas, I., Heaton, T.J., Hogg, A.G., Hughen, K.A., Kaiser, K.F., Kromer, B., McCormac, F.G., Manning, S.W., Reimer, R.W., Richards, D.A., Southon, J.R., Talamo, S., Turney, C.S.M., van der Plicht, J., and Weyhenmeyer, C.E., 2009, IntCal09 and Marine09 radiocarbon age calibration curves, 0-50,000 years cal BP: Radiocarbon, v. 51, no. 4, p. 1111-1150.

Richard, G.A., Julien, P.Y., and Baird, D.C., 2005, Statistical analysis of lateral migration of the Rio Grande, New Mexico: Geomorphology, v. 71, nos. 1-2, p. 139-155.

Richardson, K., and Carling, P.A., 2005, A typology of sculpted forms in open bedrock channels: Geological Society of America Special Paper 392, 108 p.

Risley, J.C., and Laenan, A., 1999, Upper Klamath Lake Basin nutrient-loading study-Assessment of historic flows in the Williamson and Sprague Rivers: U.S. Geological Survey Water-Resources Investigations Report 98-4198, 22 p., http://pubs.er.usgs.gov/publication/wri984198.

Risley, John, Stonewall, Adam, and Haluska, Tana, 2008, Estimating flow-duration and low-frequency statistics for unregulated streams in Oregon: U.S. Geological Survey Scientific Investigations Report 2008-5126, 23 p., http:// pubs.usgs.gov/sir/2008/5126/.

Rodnight, H., Duller, G.A.T., Tooth, S., and Wintle, A.G., 2005, Optical dating of a scroll-bar sequence on the Klip River, South Africa, to derive the lateral migration rate of a meander bend: The Holocene, v. 15, no. 6, p. 802-811.

Sarna-Wojcicki, A.M., and Davis, J.O., 1991, Quaternary tephrochronology, in Morrison, R.B., ed., The geology of North America-Quaternary nonglacial geologyConterminous U.S.: Boulder, Geological Society of America, v. K2, p. 93-116.

Schulz, T.T., and Leininger, W.C., 1990, Differences in riparian vegetation structure between grazed areas and exclosures: Journal of Range Management, v. 43, no. 4, p. 295-299.

Schumm, S.A., 1999, Causes and controls of channel incision, in Darby, S.E., and Simon, A., eds., Incised river channels, processes, forms, engineering, and management: Chicheseter, United Kingdon, Wiley, p. 19-33.
Shanmugam, S., and Barnsley, M., 2002, Quantifying landscape-ecological succession in a coastal dune system using sequential aerial photography and GIS: Journal of Coastal Conservation, v. 8, p. 61-68.

Sherrod, D.R., and Pickthorn, L.B.G., 1992, Geologic map of the west half of the Klamath Falls 1 degree by 2 degree quadrangle, south-central Oregon: U.S. Geological Survey Miscellaneous Investigations Series Map I-2182., http:// pubs.er.usgs.gov/publication/i2182.

Shields , F.D., Jr., Lizotte , R.E., Jr., Knight, S.S., Cooper, C.M., and Wilcox, D., 2010, The stream channel incision syndrome and water quality: Ecological Engineering, v. 36, no. 1, p. 78-90.

Simenstad, C.A., Burke, J.L., O’Connor, J.E., Cannon, C., Heatwole, D.W., Ramirez, M.F., Waite, I.R., Counihan, T.D., and Jones, K.L., 2011, Columbia River estuary ecosystem classification-concept and application: U.S. Geological Survey Open-File Report 2011-1228, 54 p., http://pubs.usgs.gov/of/2011/1228/.

Simon, A., 1989, The discharge of sediment in channelized alluvial streams: Journal of the American Water Resources Association, v. 25, no. 6, p. 1177-1188.

Simon, A., Curini, A., Darby, S.E., and Langendoen, E.J., 1999, Streambank mechanics and the role of bank and near-bank processes in incised channels, in Darby, S.E., and Simon, A., eds., Incised river channels-Processes, forms, engineering and management: London, Wiley, p. 123-152.

Simon, A., and Hupp, C.R., 1986, Channel evolution in modified Tennessee channels: Proceedings of the Federal Interagency Sedimentation Conference, 4th, Las Vegas, Nevada, 1986, v. 2, p. 71-82.

Simon, A., and Rinaldi, M., 2006, Disturbance, stream incision, and channel evolution-The roles of excess transport capacity and boundary materials in controlling channel response: Geomorphology, v. 79, p. 361-383.

Slingerland, R., and Smith, N.D., 2004, River avulsions and their deposits: Annual Review of Earth and Planetary Sciences, v. 32, p. 257-285.

Smith, D.G., and Pearce, C.M., 2002, Ice jam-caused fluvial gullies and scour holes on northern river flood plains: Geomorphology, v. 42, nos. 1-2, p. 85-95.

Smith, H.G., and Dragovich, D., 2009, Interpreting sediment delivery processes using suspended sediment-discharge hysteresis patterns from nested upland catchments, southeastern Australia: Hydrological Processes, v. 23, no. 17, p. 2415-2426. 
Spier, L., 1930, Klamath ethnography: Berkeley, California, University of California Publications in Archaeology and Ethnology, 338 p.

Thomas, D.S.G., and Goudie, A.S., 2000, The dictionary of physical geography: Malden, Massachusetts, Blackwell Publishers Ltd., $624 \mathrm{p}$.

Thorne, C.R., Hey, R.D., and Newson, M.D., 1997, Applied fluvial geomorphology for engineering and management: West Sussex, United Kingdom, Wiley, 376 p.

Trimble, S.W., and Mendel, A.C., 1995, The cow as a geomorphic agent-A critical review: Geomorphology, v. 13 , no. $1-4$, p. $233-253$.

U.S. Department of Agriculture, 1975, Soil taxonomy-A basic system for making and interpreting soil surveys: U.S. Department of Agriculture, Soil Conservation Service Soil Survey Staff, Handbook 436, 754 p.

U.S. Department of Agriculture, 2009, Sprague River conservation effects assessment project (CEAP) study report: U.S. Department of Agriculture, Natural Resources Conservation Service, $100 \mathrm{p}$.

U.S. Department of Agriculture, 2012, Geospatial data gateway: U.S. Department of Agriculture, Natural Resources Conservation Service database, accessed November 19, 2013, at http://datagateway.nrcs.usda.gov/.

U.S. Geological Survey, 2012, EarthExplorer: U.S. Geological Survey database, accessed November 20, 2013, at http:// earthexplorer.usgs.gov.

U.S. Geological Survey, 2013, Sprague River Basin geomorphology — links to Sprague River Basin GIS data: U.S. Geological Survey database, accessed November 20, 2013, at http://or.water.usgs.gov/proj/Sprague/data.html.

Wallick, J.R., Anderson, S.W., Cannon, C., and O'Connor, J.E., 2010, Channel change and bed-material transport in the lower Chetco River, Oregon: U.S. Geological Survey Scientific Investigations Report 2010-5065, 68 p., http:// pubs.usgs.gov/sir/2010/5065/.

Wallick, J.R., Lancaster, S.T., and Bolte, J.P., 2006, Determination of bank erodibility for natural and anthropogenic bank materials using a model of lateral migration and observed erosion along the Willamette River, Oregon, USA: River Research and Applications, v. 22, no. 6, p. 631-649.
Wallick, J.R., O'Connor, J.E., Anderson, S.W., Keith, M.K., Cannon, C., and Risley, J.C., 2011, Channel change and bed-material transport in the Umpqua River Basin, Oregon: U.S. Geological Survey Scientific Investigations Report 2011-5041, p. 112., http://pubs.usgs.gov/sir/2011/5041/.

Watershed Sciences, Inc., 2000, Remote sensing survey of the Upper Klamath River Basin-Thermal infrared and color videography: Prepared for the Oregon Department of Environmental Quality, Corvallis, Oregon, 37 p., accessed November 20, 2013, at http://www.deq.state.or.us/wq/tmdls/ docs/klamathbasin/flir/upklamath.pdf.

Watershed Sciences, Inc., 2005, Sprague River lidar remote sensing and data collection: Prepared for the Klamath Tribes, Chiloquin, Oregon, 44 p., accessed November 20, 2013, at http://www.oregongeology.org/sub/projects/olc/ watershedsci/Sprague_River_Lidar_Report_2005.pdf.

White, C.A., 1983, A history of the rectangular survey system: Bureau of Land Management, $774 \mathrm{p}$.

Williams, G.E., 1971, Flood deposits of the sand-bed ephemeral streams of central Australia: Sedimentology, v. 17, nos. 1-2, p. 1-40.

Williams, G.P., 1986, Sediment concentration versus water discharge during single hydrologic events in rivers: Journal of Hydrology, v. 111, nos. 1-4, p. 89-106.

Williams, G.P., and Wolman, M.G., 1984, Downstream effects of dams on alluvial rivers: U.S. Geological Survey Professional Paper 1286, p. 83., http://pubs.er.usgs.gov/ publication/pp1286.

Wohl, E., Angermeier, P.L., Bledsoe, B., Kondolf, G.M., MacDonnell, L., Merritt, D.M., Palmer, M.A., Poff, N.L., and Tarboton, D., 2005, River restoration: Water Resources Research, v. 41, no. 10, 12 p.

Wolman, M.G., 1967, A cycle of sedimentation and erosion in urban river channels: Geografiska Annaler-Series A, Physical Geography, v. 49, nos. 2-4, p. 385-395.

Zdanowicz, C.M., Zielinski, G.A., and Germani, M.S., 1999, Mount Mazama eruption-Calendrical age verified and atmospheric impact assessed: Geology, v. 27, no. 7, p. 621-624. 


\section{Appendixes}

Appendixes are Microsoft ${ }^{\odot}$ Excel files and are available for download at http://pubs.usgs.gov/sir/2014/5223.

Appendix A. Locations of Stratigraphic Analysis, Sprague River Study Area, Oregon

Appendix B. Radiocarbon Analyses, Sprague River Study Area, Oregon

Appendix C. Volcanic Glass Compositions of Tephra, Sprague River Study Area, Oregon

Appendix D. Cesium-137 Content, Sprague River Study Area, Oregon

Appendix E. Geomorphic Map Units, Sprague River Study Area, Oregon

Appendix F. Comparison of General Land Office Section-Line Measurements of River Width with Width from 2000 Aerial Photographs, Sprague River Study Area, Oregon

Appendix G. Survey Sites of Effects of 2006 High Flows, Sprague River Study Area, Oregon

Appendix H. Vegetation Transitions in the Geomorphic Flood Plain and Near-Channel Areas for 1940-1968 and 1968-2000, Sprague River Study Area, Oregon 

Publishing support provided by the U.S. Geological Survey Science Publishing Network, Tacoma Publishing Service Center

For more information concerning the research in this report, contact the Director, Oregon Water Science Center

U.S. Geological Survey

2130 SW 5th Avenue

Portland, Oregon 97201

http://or.water.usgs.gov 


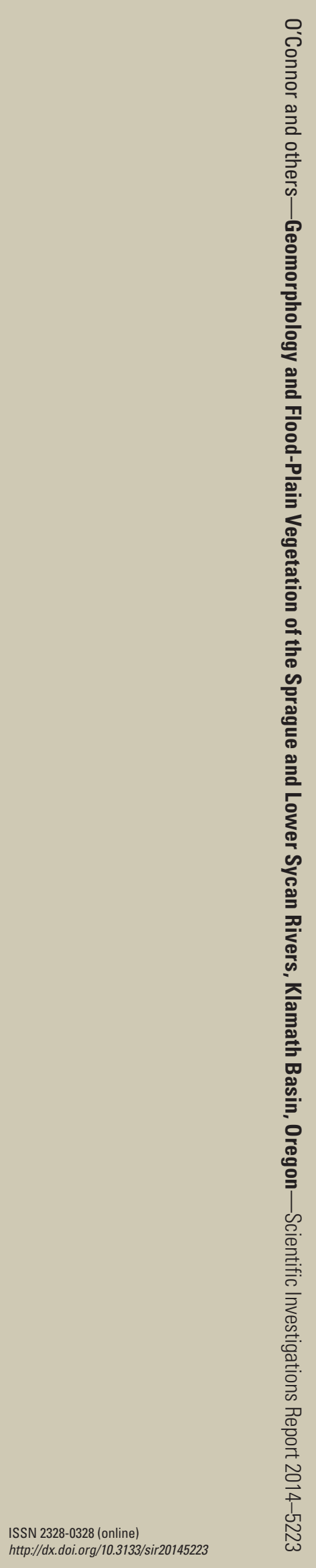

